Universidade de São Paulo

Instituto de Física de São Carlos

Instituto de Química de São Carlos

Escola de Engenharia de São Carlos

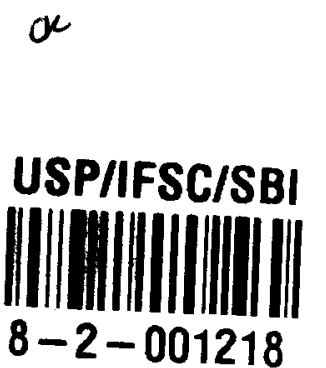

\title{
Filmes de Langmuir e Langmuir-Blodgett de polianilinas
}

\section{Antonio Riul Jr.}

Tese apresentada à área de Interunidades em Ciência e Engenharia de Materiais, do IFSC, IQSC, e EESC, para a obtenção do título de Doutor em Ciência e Engenharia de Materiais

ORIENTADOR: Prof. Dr. OSVALDO NOVAIS DE OLIVEIRA Jr. CO-ORIENTADOR: Dr. LUIZ HENRIQUE CAPPARELLI MATTOSO 
Riul Jr., Antonio

Filmes de Langmuir e Langmuir-Blodgett (LB) de polianilinas.

São Carlos, 1998.

$145 p$.

Tese (Doutorado) - Instituto de Física de São Carlos, 1998.

Orientador: Prof Dr. Osvaldo Novais de Oliveira Jr.

Co-orientador: Dr. Luiz Henrique Capparelli Mattoso

1.Langmuir- Blodgett. 2. Polianilina. 3. 16-mero.

I. Título 
Dedico essa Tese a Deus, à minha mãe, à memória de meu pai, aos meus irmãos, à minha esposa e filho, e a todos os meus amigos. 


\section{AGRADECIMENTOS}

A Deus pela alegria de viver.

Ao Prof. Osvaldo Novais de Oliveira Jr. pela orientação, amizade, apoio, confiança e ajuda, fornecidos ao longo desses anos de trabalho. Seu exemplo e dedicação contribuem muito para minha formação profissional. Seu trabalho foi além daquele de orientador, e espero um dia poder retribuir tudo o que tem feito por mim.

Ao Dr. Luiz H.C. Mattoso pela constante colaboração, dedicação, amizade e confiança. Suas sugestões sempre foram oportunas e seu apoio muito importante para a complementação desse trabalho. Não posso deixar de agradecer a oportunidade de trabalhar com o 16-mero. Indiretamente agradeço aqui ao Prof. Alan G. MacDiarmid pelo fornecimento do oligômero.

Ao Dr. Anantharaman Dhanabalan pela amizade e ajuda, além do constante aprendizado com novas técnicas de caracterização e discussões científicas. Sem sua colaboração com certeza essa tese de doutorado teria um rumo completamente diferente. As publicações, informações e o ritmo de trabalho adquirido foram conseqüência da convivência com ele. Obrigado Dhan.

À Sarita pela amizade sincera e confiança ao longo desses anos. Muito do que aprendi deve-se a sua inesgotável paciência e preciosa colaboração nas horas mais dificeis. Mais do que amiga foi meu braço direito.

Ao Casé pela amizade, discussões e sugestões nesses anos todos. Sua irreverência com certeza foi uma ponte de equilíbrio nas situações mais tensas, e sua alegria uma motivação. Obrigado pelas aulas de didática.

Ao Dr. Ailton Cavali, a Prof. Galina e ao Pira pela amizade e paciência. As medidas de condutância ainda irão servir.

Ao Bertho, Níbio, Ademir, Rosângela e Débora pela inestimável colaboração para que esse trabalho pudesse ser realizado com sucesso. Sem a presença de vocês esse Grupo não seria um lugar tão agradável de se conviver.

Ao Prof. Roberto M. Faria pela iniciativa em trabalhar com polímeros condutores, e pelas sugestões e discussões a respeito dos resultados de raios-X e condutividade elétrica.

Aos Profs. Guilherme, Mariângela e Giacometti pela agradável convivência e eventuais dicas.

À Dra. Liliane M. de Souza e ao Prof. Edson A. Ticianelli do IQSC pelas medidas de elipsometria, e discussões dos resultados obtidos. Ao Dr. Carlos Cruz pelo fornecimento da $\mathrm{PANi}_{2}$. 
Ao Mal, aos professores Wladmir Shapovalov e Heinz, ao Paulo e a Fátima, ao Haroldo e ao Rodrigo, pela amizade e colaboração nas medidas de raios- $\mathrm{X}$ e condutividade elétrica. As discussões foram muito construtivas, e a ajuda na hora certa. Obrigado pela atenção dada.

Ao Fonseca pelas dicas, e ao Tomioka pelo socorro computacional dado nos piores momentos. Ao Dante, Chicão, Mantovani, Lucas, Mauro, Mané, Pedrão, Romildo, Walterley, Xuxa, Ivo, Cristiano, Josmary, Cibele, Aldo, Débora, Célio, China, David, Celso, Glênio, e a Sandra pela amizade e convivência.

Ao Mauro e a Silvana do IQSC pela boa vontade e disposição nas medidas de FTIR. Ao Augusto do IFSC pelas medidas de difração de raios-X.

Ao Prof. Glaucius e à Wanda, do grupo de cristalografia, pela utilização do espectrofotômetro.

À Prof. Mônica Cotta do Instituto de Física Glebb Wattaghin, da Unicamp, e ao Herrmann, da EMBRAPA/CNPDIA de São Carlos, pelas medidas e discussões de AFM.

Ao Leonardo pela ajuda durante as medidas de microscopia óptica na EMBRAPA.

À minha mãe por todo amor dado. Sem o seu sacrificio constante e sua ajuda não sei o que seria de mim. Aos meus irmãos, meus tios Alan e Elcy, ao Galvão e a Maié, pela ajuda e pelo carinho nesses anos de mudança.

À Cá e ao Véio (André) pela alegria, amor, dedicação e paciência. A mudança foi brusca, mas muito boa.

Ao Pé, Guimes, Val, Mirão, Bahia, Zé do Rodo, Boy, Paulinho, Ciro, aos mestres João Pequeno, Diogo, Fernando, Dois de Ouro, Brandão, Lua de Bobó e a todo pessoal da academia por não me deixarem esquecer que a vida continua sendo a melhor escola.

À Élvia pelo apoio e incentivo para que eu não parasse as aulas de inglês.

Àqueles que eu esqueci, meu muito obrigado

À FAPESP pelo apoio financeiro. 


\section{ÍNDICE}

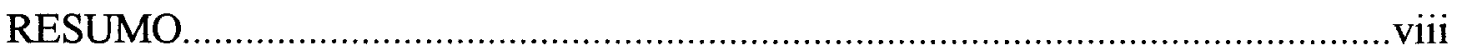

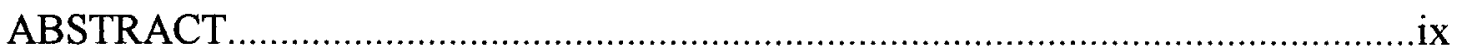

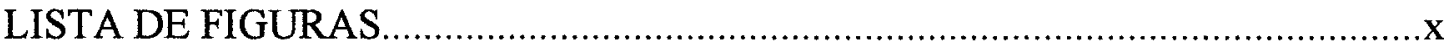

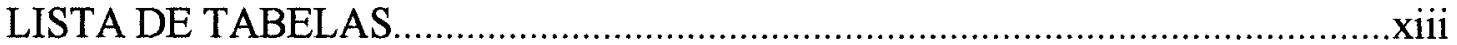

LISTA DE ABREVIATURAS E SIGLAS .........................................................

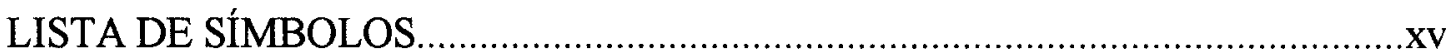

\section{CAPÍTULO 1}

\section{1}

Introdução ___ 1

1.1) Motivação____ 1

1.2) Objetivos _ـ 3

1.3) Concepção da Tese __ 4

1.4) Revisão da literatura sobre filmes $L B$ de polianilinas ___ 5

CAPÍTULO 2

2) Caracterização dos filmes de Langmuir de Polianilinas ___ 12

2.1) Filmes mistos de polianilina e 16-mero com estearato de cádmio ___ 12

2.1.1) Introdução _ 12

2.1.2) Parte Experimental 13

2.1.2.1) Soluções de PANi _ 13

2.1.2.2) Soluções de 16-mero

2.1.3) Caracterização dos filmes de Langmuir ___ 14

2.1.3.1) Pressão de superfície

2.1.3.2) Potencial de superficie___ 21

2.2) Efeito de protonação nas monocamadas, devido à variação do $\mathrm{pH}$ na subfase, verificado pelo potencial de superficie dos filmes de Langmuir de polianilinas. _ 24

2.2.1) Introdução __

2.2.2) Parte experimental __ 26

2.2.3) Resultados 26

2.2.4) Conclusões ___ 34

CAPÍTULO 3

Caracterização dos filmes LB de polianilinas ___ 36

3) Filmes LB mistos de PANi e 16-mero com estearato de cádmio ___ 36

3.1) Introdução — 36

3.2) Parte experimental __ 37

3.3) Fabricação de filmes LB _ 38

3.4) Caracterização espectroscópica dos filmes LB __ 39

3.4.1) UV-vis, 39

3.4.2) FTIR 43 


\section{RESUMO}

RIUL Jr., A. Filmes de Langmuir e Langmuir-Blodgett de polianilinas. São Carlos, 1998. 145p. Tese (Doutorado) - Instituto de Física de São Carlos, Universidade de São Paulo.

Explorou-se a caracterização de monocamadas e filmes LB de polianilina (PANi), e um oligômero de polianilina, chamado aqui de 16-mero, com estearato de cádmio (CdSt). A análise dos filmes de Langmuir indicou que possivelmente não há mistura em nível molecular da PANi e do 16-mero com CdSt, ainda que a quantidade adicionada em solução de polímero ou oligômero influencie a estabilidade das monocamadas. Utilizou-se UV-vis, FTIR, difração de raios-X, condutividade elétrica, elipsometria, microscopia óptica e potencial de superfície para caracterização dos filmes LB. Os resultados de UV-vis indicaram uma transferência uniforme e ainda que os filmes recém depositados encontram-se desdopados. A análise de FTIR confirma a presença de CdSt nos filmes LB, e o efeito de desdopagem em subfases neutras, corroborando os resultados de UV-vis. A difração de raios-X indica a presença de domínios separados de PANi (e 16-mero) com CdSt nos filmes LB. Resultados elipsométricos indicaram uma espessura por camada em torno de $25 \AA$. A excelente uniformidade obtida nos filmes LB mistos foi comprovada pelos resultados de microscopia óptica e potencial de superficie. Esses filmes mistos apresentaram valores de condutividade elétrica em torno de $10^{-4}$ a $10^{-5}$ ${\mathrm{S} . \mathrm{cm}^{-1}}^{-1}$ (van der Pauw), tanto para a PANi quanto para o 16-mero. Investigou-se também o efeito da exposição dos filmes mistos PANi/CdSt aos raios-X. Nota-se um deslocamento para a região do vermelho, na região do visível, nos espectros de UVvis, similar à observada pela dopagem através de ácidos inorgânicos. Verificou-se que os efeitos de umidade da atmosfera de medida são predominantes nesse processo de dopagem. É feita uma análise dos resultados de condutividade elétrica, comparando-os com os encontrados na literatura.

Palavras-chave: Langmuir-Blodgett, polianilina, 16-mero 


\begin{abstract}
RIUL Jr., A. Filmes de Langmuir e Langmuir-Blodgett de polianilinas. São Carlos, 1998. 145p. Tese (Doutorado) - Instituto de Física de São Carlos, Universidade de São Paulo.
\end{abstract}

A study has been made of composite Langmuir and Langmuir-Blodgett (LB) films of polyaniline (PANi), and a polyaniline oligomer (16-mer polyaniline), with cadmium stearate $(\mathrm{CdSt})$. The monolayers studies pointed to a phase separated system containing the polymer (or the 16-mer) and CdSt, with no mixing at the molecular level, although the relative contents of PANi and 16-mer in the solution have a strong influence on the monolayer stability. UV-vis, FTIR, X-ray diffraction (XRD), electrical conductivity, ellipsometry, optical microscopy and surface potential measurements were used in the LB film characterization. UV-vis results have shown a uniform transfer, with the as deposited films in the undoped state. FTIR results confirmed the presence of CdSt and undoped polyaniline (and 16-mer) in the transferred LB films, corroborating the UV-vis results. XRD has shown separated domains of CdSt and PANi (16-mer also) in the LB films. Ellipsometry data indicated a thickness of $25 \AA$ per deposited layer. The high uniformity in these mixed LB films was confirmed by optical microscopy and surface potential measurements. The electrical conductivity was approximately $10^{-5}$ to $10^{-4}{\mathrm{~S} . \mathrm{cm}^{-1}}_{\text {for }}$ both PANi and 16-mer. Mixed PANi/CdSt films were also exposed to X-ray irradiation. After a given dose rate there is a red shift in the UV-vis spectra from the $600 \mathrm{~nm}$ region to the $800 \mathrm{~nm}$ region, similar to the usual acid doping process observed in polyaniline. Humidity effects have a strong influence on the doping process. A comparison is made of the conductivity measurements made here with those reported in the literature.

Key-words: Langmuir-Blodgett, polyaniline, 16-mer polyaniline 


\section{LISTA DE FIGURAS}

FIGURA I-Representação esquemática da polianilina na base esmeraldina

FIGURA 2 - Curvas de pressão de superficie para as monocamadas mistas de polianilina com estearato de cádmio em diferentes composições de PANi.

FIGURA 3 - Curvas de pressão de superfície para as monocamadas mistas de 16-mero com estearato de cádmio em diferentes composições de 16-mero.

FIGURA 4 - Variação da área molecular por molécula de ácido, em função da percentagem de polimero nas monocamadas mistas de PANi/CdSt.

FIGURA 5 - Variação da área molecular média (A), extrapolada das curvas (IIX A), e da área critica ( $\square)$, obtida das curvas ( $\triangle V X A)$, em função da variação da percentagem, em massa, de 16-mero na solução.

FIGURA 6 - Variação da área molecular, calculada em função da massa molar média de PANi e ácido esteárico, para diferentes percentagens de polímero na solução.

FIGURA 7 - Variação da área molecular, calculada em função da massa molar média de 16-mero e ácido esteárico, para diferentes percentagens de oligômero na solução, utilizadas para formação de monocamadas mistas de 16-mero/CdSt.

FIGURA 8 - Curvas de estabilidade das monocamadas mistas de 16-mero/CdSt nas diferentes percentagens utilizadas.

FIGURA 9 - Curvas de potencial de superficie em função da área por molécula para diferentes percentagens de PANi nas monocamadas mistas.

FIGURA 10 - Curvas de potencial de superficie em função da área por molécula para diferentes percentagens de 16-mero nas monocamadas mistas.

FIGURA 11 - Variação do valor máximo atingido pelo potencial de superficie nos filmes de Langmuir de PANi, em função da dopagem através de subfases ácidas. (a) $\mathrm{HClO}_{4}$; (b)

$\mathrm{CF}_{3} \mathrm{COOH}$; (c) $\mathrm{H}_{2} \mathrm{SO}_{4}$; (d) $\mathrm{HCl}$.

FIGURA 12 - Variação do valor máximo atingido pelo potencial de superficie nos filmes de Langmuir de POEA, em função da dopagem através de subfases ácidas.(a) $\mathrm{HClO}_{4}$; (b) $\mathrm{CF}_{3} \mathrm{COOH}$; (c) $\mathrm{H}_{2} \mathrm{SO}_{4}$; (d) $\mathrm{HCl}$.

FIGURA 13 - Variação do potencial de superficie para a PANi para um valor fixo de pH, em função do ácido utilizado na subfase.

FIGURA 14 - Variação do potencial de superficie para a POEA para um valor fixo de $\mathrm{pH}$, em função do ácido utilizado na subfase.

FIGURA 15 - Variação do valor máximo atingido pelo potencial de superficie nos filmes Langmuir de POEA pré-dopada, em função da dopagem através de subfase ácida $\left(\mathrm{HClO}_{4}\right) . \quad 31$

FIGURA 16- Espectro UV-vis de uma monocamada mista de PANi e estearato de cádmio: a) logo após a deposição; $b$ ) dopado em vapor de HCl por dez minutos.

FIGURA 17 - Espectro UV-vis de uma monocamada mista de 16-mero e estearato de cádmio: a) logo após a deposição; b) dopado em vapor de HCl por dez minutos.

FIGURA 18 - Variação da absorbância em função do número de camadas depositadas, em $590 \mathrm{~nm}$, para filmes mistos de PANi e estearato de cádmio.

FIGURA 19 - Variação da absorbância em função do número de camadas depositadas, em $590 \mathrm{~nm}$, para filmes mistos de 16-mero e estearato de cádmio em diferentes percentagens de 16mero em massa na solução: (प) 25\%; (O) $50 \%$; (4) $75 \%$.

FIGURA 20 - Variação da absorbância por camada depositada em função da percentagem utilizada de 16-mero na solução.

FIGURA 21 - Espectro de transmitância de FTIR de filme LB misto de PANi (55\% de polímero em massa na solução) e estearato de cádmio.

FIGURA 22 - Espectro de FTIR de filmes LB mistos (21 camadas) contendo diferentes percentagens de 16-mero e estearato de cádmio: a) 25\%; b) 50\% e c) 75\% de 16-mero na solução de espalhamento.

FIGURA 23 - Representação esquemática dos domínios de polianilina (ou 16-mero) com estearato de cádmio nos filmes $L B$.

FIGURA 24 - Espectros de difraçâo de raios-X em filmes $L B$ mistos de PANi com estearato de cádmio: a) CdSt puro; b) $30 \%$ de PANi; c) 43\% de PANi; d) $55 \%$ de PANi; e) $66 \%$ de $P A N i$ 
FIGURA 25 - Espectros de difração de raios-X de filmes LB (21 camadas) contendo diferentes percentagens, em massa, de 16-mero e CdSt: (a) 25\%; (b) 50\%; (c) 64\% e (d) $75 \%$ de 16-mero.

FIGURA 26 - Representação esquemática dos domínios de polianilina com estearato de cádmio nos filmes LB quando elevadas percentagens de polímero são adicionadas em solução. _ 48

FIGURA 27 - Variação do indice de refração (n) e coeficiente de extinção (k), obtidos por elipsometria, em um filme $L B$ de polianilina pura, contendo 9 camadas, utilizando subfase ácida $(p H \sim 2)$.

FIGURA 28 - Curvas ( $\Pi X$ A) de monocamadas de PANi processada com CSA na ausência (a) e na presença (b) de m-cresol na solução inicial, em subfases ácidas.

FIGURA 29 - Curvas (ПX A) de filmes LB mistos, contendo $50 \%$ em peso, de PANi/CdSt na ausência (a) e na presença (b) de $m$-cresol durante o processamento do polímero. 62

FIGURA 30 - Curvas de potencial de superficie para monocamadas de polianilina: (a) pura, formadas sobre subfases ácidas ( $p H=2, T S A$ ) e (b) filmes mistos de PANi com estearato de cádmio.

FIGURA 31 - Espectros de UV-vis dos filmes $L B$ de PANi processada das seguintes formas: 65

FIGURA 32 - Espectros de UV-vis de filmes LB mistos contendo $50 \%$ em massa de PANi e CdSt. (a) PANi processada na ausência de m-cresol, e (b) PANi processada na presença de $m$ cresol.

FIGURA 33 - Espectros de difração de raios-X em filmes $L B$ mistos contendo $50 \%$ em massa na solução de PANi/CSA com CdSt. (a) PANi processada na ausência de m-cresol, e (b) PANi processada na presença de $m$-cresol.

FIGURA 34 - Espectros de UV-vis para filmes LB mistos de polianilina com estearato de cádmio (21 camadas) durante os estágios iniciais de irradiação, em atmosfera ambiente ( $\sim 50 \%$ de umidade).

FIGURA 35 -Espectros de UV-vis para filmes mistos de polianilina com estearato de cádmio (21 camadas), irradiados em atmosfera ambiente ( $50 \%$ de umidade), após um tempo prolongado de irradiação.

FIGURA 36 - Espectros de FTIR de filmes LB mistos de polianilina com CdSt: (a) recém depositados $e$ (b) expostos aos raios-X por 3 horas em atmosfera ambiente ( $50 \%$ de umidade) $\quad 76$

FIGURA 37 - Espectro de difração de raios-X de filmes LB mistos de polianilina com CdSt. (a) recém depositado, e (b) irradiado por 3 horas em atmosfera ambiente ( $-50 \%$ de umidade). 77

FIGURA 38 - Espectros UV-vis para um filme $L B$ contendo 84 camadas irradiado a atmosfera ambiente ( $50 \%$ de umidade) em diferentes intervalos de tempo, num total de 760 minutos de irradiação.

FIGURA 39 - Espectros UV-vis para um filme LB contendo 84 camadas irradiado em atmosfera 78 ambiente a 90\% de umidade, em diferentes intervalos de tempo, num total de 210 minutos de irradiação.

FIGURA 40 - Espectros UV-vis para filmes LB de PANi contendo 13 camadas, irradiados durante 45 minutos no vácuo e em atmosfera ambiente a $70 \%$ de umidade.

FIGURA 41 - Espectros UV-vis para filmes $L B$ de PANi contendo 13 camadas em atmosfera de oxigênio. a) recém depositado; b) irradiado 45 minutos

FIGURA 42 - Espectros UV-vis para filmes $L B$ de PANi contendo 13 camadas em atmosfera de nitrogênio. a) recém depositado; b) irradiado 45 minutos em atmosfera de nitrogênio super-seco; c) irradiado 45 minutos em atmosfera de nitrogênio a $84 \%$ de umidade. 81

FIGURA 43 - Espectros UV-vis para filmes $L B$ de PANi contendo 13 camadas em atmosfera de argônio. a) recém depositado; b) irradiado 45 minutos em atmosfera de argônio; irradiado 45 minutos em atmosfera de argônio a $85 \%$ de umidade.

FIGURA 44 - Variação no espectro de UV-vis em um filme LB de PANi contendo 13 camadas, em atmosfera de oxigênio.

FIGURA 45 - Espectros UV-vis para um filme LB contendo 11 camadas irradiado em atmosfera ambiente a $90 \%$ de umidade, em diferentes intervalos de tempo, num total de 45 minutos de irradiação.

FIGURA 46 - Espectros UV-vis para um filme LB contendo 40 camadas irradiado em atmosfera ambiente a $90 \%$ de umidade, em diferentes intervalos de tempo, num total de 130 minutos de irradiação. 
FIGURA 47 - Espectros UV-vis para um filme LB contendo 120 camadas irradiado em atmosfera ambiente a $90 \%$ de umidade, em diferentes intervalos de tempo, num total de 340 minutos de irradiação.

FIGURA 48 - Variação do tempo necessário para o aparecimento da banda de absorção polarônica nos espectro de UV-vis em função de espessura de filmes $L B$ de PANi/CdSt, irradiados a $90 \%$ de umidade, em diferentes intervalos de tempo.

FIGURA 49 - Efeito de dopagem ao vapor de $\mathrm{HCl}$, e efeitos de exposição aos raios-X mum filme $L B$ contendo 19 camadas depositadas

FIGURA 50 - Dopagem e desdopagem de um filme LB de PANi, contendo 84 camadas, após 760 minutos de irradiação em atmosfera ambiente a $50 \%$ de umidade.

FIGURA 51 - Dopagem e desdopagem de um filme LB de PANi, contendo 84 camadas, após 240 minutos de irradiação a $90 \%$ de umidade.

FIGURA 52 - Espectros $U V$-vis para um filme $L B$ de PANi, contendo 23 camadas, exposto ao vapor de m-cresol por 2 dias e irradiado durante 224 minutos em atmosfera ambiente a $50 \%$ de umidade.

FIGURA 53 - Espectros UV-vis para um filme LB, contendo 23 camadas, irradiado durante 50 minutos a 90\% de umidade e, posteriormente, exposto ao vapor de m-cresol por 2 dias.

FIGURA 54 - Variações no espectro de UV-vis em filmes LB de PANi contendo 23 camadas, sem irradiação, em diferentes condições de umidade.

FIGURA 55 - Variações no espectro de UV-vis de um filme LB de PANi contendo 84 camadas, mantido em repouso em atmosfera ambiente a $90 \%$ de umidade.

FIGURA 56 - Variação no espectro de UV-vis em um filme LB de PANi contendo 40 camadas, mantida em repouso por dezoito horas em atmosfera a $90 \%$ de umidade, após um hora de irradiação.

FIGURA 57 - Espectros UV-vis para um filme LB contendo 10 camadas: a) recém depositado; b) irradiado 45 minutos em atmosfera de argônio; c) irradiado 30 minutos em atmosfera ambiente a $90 \%$ de umidade com uma placa de quartzo de $1 \mathrm{~mm}$ de espessura sobre $o$ mesmo.

FIGURA 58 - Espectros UV-vis para filmes $L B$ contendo 21 camadas, irradiados durante 40 minutos em atmosfera ambiente ( $\sim 50 \%$ de umidade): a) recém depositado; b) irradiado ao ar livre; c) irradiado dentro do tuperware.

FIGURA 59 - Espectros $U V$-vis para um filme $L B$ contendo 10 camadas coberto com uma placa de chumbo de 1,5 mm de espessura: a) recém depositado; b) irradiado 40 minutos em atmosfera ambiente a $50 \%$ de umidade; c) irradiado 40 minutos em atmosfera ambiente a $90 \%$ de umidade.

FIGURA 60 - Representação esquemática do método de medida de condutividade elétrica utilizando dois pontos de contato.

FIGURA 61-Representação esquemática do método de medida de condutividade elétrica através de quatro pontas colineares. 105

FIGURA 62 - Representação esquemática do método de medidas de quatro pontas eqüidistantes, mas não colineares.

FIGURA 63 - Representação esquemática das medidas de condutividade elétrica utilizando o método de van de Pauw.

FIGURA 64 - Representação esquemática do comportamento para a condutividade a.c. em materiais desordenados. 109

FIGURA 65 - Representação esquemática da disposição dos contatos elétricos nas medidas de condutividade a.c.. A e B representam os pontos nos quais foram presos os fios para realização das medidas.

FIGURA 66 - Comportamento da componente real da condutividade complexa em função da freqüência, em filmes $L B$ mistos de PANi com CdSt.

FIGURA 67 - Variação da condutividade a $1 \mathrm{~Hz}$ em filmes LB mistos de PANi/CdSt, variando o tempo de exposição da amostra aos raios- $X$. 


\section{LISTA DE TABELAS}

TABELA I - Variação do potencial de superficie da PANi em função do pH da subfase.

TABELA 2 - Variação do potencial de superficie da POEA não pré-dopada em função do $p H$ da subfase.

TABELA 3 - Variação do potencial de superfície da POEA pré-dopada em função do pH da subfase.

TABELA 4 - Valores de potencial de superficie para filmes $L B$ mistos contendo diferentes quantidades de PANi e estearato de cádmio. 50

TABELA 5 - Valores de potencial de superficie para filmes $L B$ mistos contendo diferentes quantidades de 16-mero e estearato de cádmio.

TABELA 6 - Resultados elipsométricos (constantes ópticas e espessura por camada) de filmes LB contendo diferentes percentagens de PANi e CdSt.

$T A B E L A 7$ - Resultados elipsométricos (constantes ópticas e espessura por camada) de filmes $L B$ contendo diferentes percentagens de 16-mero e CdSt.

TABELA 8 - Valores máximos atingidos pelo potencial de superficie em filmes $L B$ mistos, contendo $50 \%$ em massa, de PANi e estearato de cádmio, na ausência e na presença de m-cresol em diferentes condições de subfase.

TABELA 9-Resultados de condutividade elétrica (van der Pauw) em filmes LB de polianilina processada apenas com CSA, obtidos em subfases ácidas.

TABELA 10 - Resultados de condutividade elétrica (van der Pauw) em filmes LB de polianilina processada com CSA e m-cresol, obtidos em subfases ácidas.

TABELA 11 -Resultados de condutividade elétrica (van der Pauw) em filmes LB mistos de polianilina com estearato de cádmio.

TABELA 12 -Resultados de condutividade elétrica (van der Pauw) em filmes LB de 16-mero processado com CSA e m-cresol, obtidos em subfases ácidas.

TABELA 13 - Resultados de condutividade elétrica (van der Pauw) em filmes LB mistos de 16-mero com estearato de cádmio.

TABELA 14-Resultados de condutividade elétrica (duas pontas) em filmes LB mistos de 16-mero com estearato de cádmio (50\%). 


\section{LISTA DE ABREVIATURAS E SIGLAS}

Ast - Ácido esteárico

AFM - Microscopia de força atômica, do inglês Atomic Force Microscopy

BAM - Microscopia no ângulo de Brewster

CA - Derivado fosforilatado de calix[4]resorcilolareno

CdSt - Estearato de cádmio

CSA - Ácido canforssulfônico

DBSA - Ácido dodecilbenzenossulfônico

DF - Demchack e Fort

FTIR - Espectroscopia na região do infravermelho

GC - Gouy Chapman

HPLC - High Perfomance Liquid Cromatography

LB - Langmuir-Blodgett

$\mathrm{nm}$ - Nanometros

NMP - N-metilpirrolidinona

PANi - Polianilina

$\mathrm{PANi}_{2}$ - Polianilina obtida por uma rota de síntese alternativa

POMA - Poli(o-anisidina)

POEA - Poli(o-etoxianilina)

TFA - Ácido trifluoracético

TR - Razão de transferência dos filmes Langmuir-Blodgett, do inglês Transfer ratio

TSA - Ácido toluenossulfônico

UV-vis - Espectroscopia na região do ultravioleta e do visível

XRD - Difração de raios-X, do inglês $X$-ray diffraction

$\mathrm{ZnSe}$ - Seleneto de zinco 


\section{LISTA DE SÍMBOLOS}

16-mero - oligômero de polianilina

A - área molecular média

a.c. - medidas elétricas em corrente alternada

$\mathrm{A}_{\mathrm{c}}$ - área crítica

$A_{e}$ - área de contato do eletrodo de medida

$\alpha$ - constante de dissociação

$\alpha^{\prime}$ - absorção óptica do material

c - concentração iônica da subfase

$\mathrm{CaF}_{2}$ - Fluoreto de cálcio

$\mathrm{CHCl}_{3}$ - Clorofórmio

$\mathrm{d}$ - espessura por camada

d.c. - medidas elétricas em corrente contínua

$\mathrm{d}_{\sigma}$ - densidade superficial de cargas na interface filme/subfase

$\triangle \mathrm{V} \mathrm{X} \mathrm{A} \mathrm{-} \mathrm{curva} \mathrm{de} \mathrm{potencial} \mathrm{de} \mathrm{superficie} \mathrm{em} \mathrm{função} \mathrm{da} \mathrm{área} \mathrm{molecular} \mathrm{média}$ $\Delta \mathrm{V}$ - potencial de superfície

$\Delta \mathrm{V}_{\mathrm{LB}}$ - potencial de superfície nos filmes Langmuir-Blodgett

$\Delta \mathrm{t}$ - intervalo de tempo

$e$ - carga eletrônica

$\varepsilon_{0}$ - permissividade elétrica do vácuo

$\varepsilon_{\mathrm{i}}$ - constante dielétrica do meio $\mathrm{i}$

$\mathrm{HCl}$ - Ácido clorídrico

$\mathrm{i}$ - corrente elétrica

$\mathrm{k}$ - coeficiente de extinção

$\mathrm{KCl}$ - Cloreto de potássio

$k$ - constante de Boltzmann

$\lambda$ - comprimento de onda

$\mu_{\mathrm{i}}$ - contribuição dipolar da parte $i$ da molécula normal a interface filme/água

$\mu_{1}$ - coeficiente de absorção linear

$\mathrm{n}$ - indice de refração 
$\Pi$ - pressão de superfície

$\Pi$ X A - curva de pressão de superfície em função da área molecular média $\Psi_{0}$ - potencial de superfície da dupla camada formada na interface filme/subfase $\mathrm{S}$ - distância de separação entre as pontas de contato para medidas de condutividade elétrica

$\sigma$ - condutividade elétrica

$\sigma^{\prime}(\omega)$ - componente real da condutividade complexa

$\sigma$ ' $(\omega)$ - componente imaginária da condutividade complexa

$\mathrm{T}$ - temperatura absoluta

$\mathrm{V}$ - diferença de potencial

$\mathrm{V}_{0}$ - valor estipulado para o potencial de superfície

$\mathrm{V}_{\mathrm{m}}$ - máximo valor do potencial de superfície

$\omega$ - freqüência

$Z^{\prime}(\omega)$ - componente real da impedância

$Z "(\omega)$ - componente imaginária da impedância 


\section{CAPÍTULO 1}

\section{Introdução}

\section{1) Motivação}

Alguns polímeros conjugados em seu estado não condutor (polímeros semicondutores) apresentam fenômenos de fotoemissão, fotodetecção e fotovoltagem como os materiais semicondutores inorgânicos convencionais. Esses polímeros podem ser dopados em diversos níveis, com condutividades elétricas variando de materiais isolantes a metálicos, possuindo ainda as vantajosas propriedades mecânicas e de processamento dos polímeros convencionais. Devido ao elevado potencial de aplicação, esses materiais têm sido extensivamente estudados e o progresso científico nessa área proporcionou o desenvolvimento de polímeros semicondutores e metálicos estáveis e processáveis. Esse avanço tecnológico permitiu aplicações em duas principais áreas de pesquisa: i) polímeros e blendas poliméricas condutoras, e ii) fabricação de dispositivos eletrônicos. Atualmente o sonho de usar tais materiais como dispositivos plásticos de alta qualidade (e performance) tem se tornado uma realidade [1-4], e o desempenho desses dispositivos poliméricos tem sido melhorado, sendo em alguns casos até melhor que seus correspondentes inorgânicos [1].

O campo de dispositivos poliméricos tem incluído desde pesquisas básicas até pesquisas para aplicações industriais abrindo novas e interessantes fronteiras. Os principais problemas para aplicações estão relacionados com a natureza da geração de cargas, transporte e recombinação em uma determinada região, que acabam afetando diretamente a eficiência dos dispositivos fabricados. No entanto, desde que seja possível alinhar as cadeias poliméricas em relação ao substrato, as propriedades de transporte dos portadores de carga ao longo da cadeia podem ser melhoradas já que a condutividade elétrica é maior nessa região [4].

A técnica desenvolvida décadas atrás por Irving Langmuir e Katherine Blodgett para controlar a espessura e arquitetura molecular de filmes finos e 
materiais orgânicos isolantes tem sido empregada, mais recentemente, para manipular e ordenar filmes finos de materiais orgânicos com propriedades eletroativas e eletroópticas (polímeros condutores) na forma de filmes LangmuirBlodgett (LB). A aplicação da técnica LB em polímeros condutores é uma resposta à necessidade atual de novos métodos que permitam a fabricação de filmes com organização molecular bem definida, algo considerado essencial para dispositivos eletrônicos mais sofisticados que os atuais. Nesse sentido, vários esforços têm sido feitos para verificar se há ou não uma melhora das propriedades elétricas de polímeros conjugados manipulados pela técnica Langmuir-Blodgett.

É exatamente na linha de pesquisa básica de fabricação de filmes LB de polímeros condutores que o trabalho por nós desenvolvido tem sido dirigido, sem o compromisso direto de desenvolvimento de dispositivos. Optou-se pela polianilina pela facilidade de síntese, elevados valores de condutividade elétrica, e excelente estabilidade química ambiental, que aumenta muito seu potencial de aplicação, tornando-a um dos polímeros condutores mais estudados no momento.

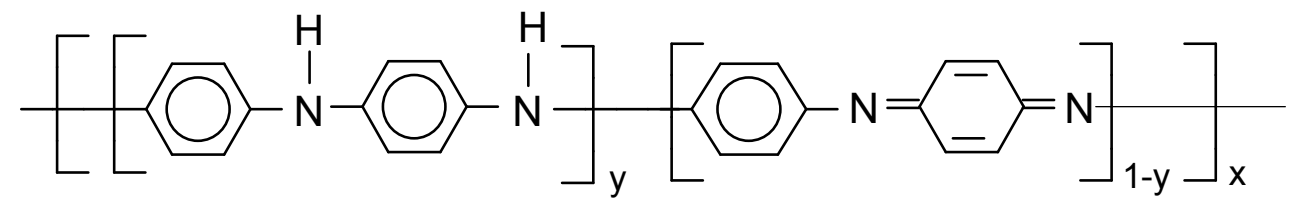

Figura 1 - Representação esquemática da polianilina na base esmeraldina

$\mathrm{Na}$ base esmeraldina o polímero é composto de y unidades de espécies reduzidas e (1-y) unidades de espécies oxidadas, repetidas alternadamente ao longo de sua estrutura, como esquematizado na Fig. 1 acima.

Os termos desdopado e não dopado, que seguem adiante ao longo do texto, referem-se ao estado não condutor das polianilinas, sendo portanto aqui sinônimos. Há esse abuso de linguagem porque durante o processo de síntese esses materiais são obtidos através de uma reação de oxidação em meio ácido, estando portanto dopados, sendo posteriormente lavados em $\mathrm{NH}_{4} \mathrm{OH}$ e acetona. A lavagem em acetona é feita para remoção de resíduos (monômeros, oligômeros, etc.) provenientes da polimerização da anilina, enquanto a desdopagem em $\mathrm{NH}_{4} \mathrm{OH}$ é realizada para tornar os materiais processáveis. 


\section{2) Objetivos}

O início deste trabalho de doutorado teve como objetivo testar novos métodos e materiais que pudessem solucionar os problemas de uniformidade nos filmes LB obtidos sobre subfases ácidas, e ainda melhorar suas propriedades elétricas. A primeira tentativa foi estudar uma polianilina obtida por rota de síntese alternativa, chamada aqui de $\mathrm{PANi}_{2}$, gentilmente fornecida pelo doutor Carlos Cruz (CEFET/Paraná). Foi realizado um estudo de otimização das condições de formação das monocamadas de $\mathrm{PANi}_{2}$ em subfases ácidas, seguindo a linha de pesquisa do trabalho de mestrado sobre a otimização das condições de formação de monocamadas de polianilina em subfases ácidas, e a posterior fabricação dos filmes LB. A dificuldade de deposição dos filmes formados em subfases ácidas, que mostraram-se não uniformes por inspeção visual, além da alta resistividade observada nos filmes LB de $\mathrm{PANi}_{2}$, pelo método de van der Pauw, nos levou ao estudo de filmes mistos de polianilina com estearato de cádmio (CdSt, do inglês "cadmium stearate"). Os resultados foram animadores pois eliminam-se as dificuldades de deposição em subfases ácidas, permitindo a obtenção de filmes LB completamente uniformes. Uma outra tentativa foi estudar um oligômero de polianilina, chamado aqui de 16-mero. Esses oligômeros possuem cadeias menores que as dos polímeros, sendo portanto facilmente processáveis. Podem ainda ter uma cristalinidade maior devido à facilidade de alinhamento dessas cadeias. Como conseqüência imediata há um aumento na condutividade inter-domínios, resultando numa condutividade volumétrica do oligômero maior que a do polímero condutor. $\mathrm{Na}$ última Conferência Internacional sobre Ciência e Tecnologia em Metais Sintéticos (ICMS'96) essa idéia foi amplamente discutida entre pesquisadores renomados na área de polímeros condutores, entre eles o Prof. Alan G. MacDiarmid, que gentilmente nos forneceu material por intermédio do Dr. Luiz Henrique Capparelli Mattoso (EMBRAPA/CNPDIA, São Carlos) para estudo dos filmes de Langmuir e fabricação de filmes LB. Os resultados serão apresentados mais adiante.

Além do trabalho diretamente pertencente a essa linha mestra de atuação, outros tópicos surgiram e foram abordados, tais como: 
i) efeito de protonação nas monocamadas obtidas em subfases ácidas devido a variações no tipo de ácido utilizado, investigado pelas variações causadas no potencial de superfície dos filmes de Langmuir;

ii) efeito do $m$-cresol na formação das monocamadas e fabricação dos filmes LB;

iii) efeitos de exposição dos filmes LB aos raios-X, causando transições eletrônicas características do polímero dopado nos espectros de UV-vis;

iv) abordagem dos problemas relativos à medida de condutividade elétrica nos filmes LB de PANi.

\section{3) Concepção da Tese}

A apresentação e discussão da formação de monocamadas mistas de polianilina e 16-mero, e a caracterização dos filmes LB obtidos será feita nos capítulos 2 e 3. No caso de utilização de subfases ácidas, a estabilidade das monocamadas de polianilina aumenta com a diminuição do valor de $\mathrm{pH}$ da subfase $[5,6]$, e o grau de dopagem atingido pelo polímero irá afetar o potencial de superfície da monocamada devido a variações conformacionais. Apesar da complexidade das macromoléculas envolvidas, os resultados foram analisados em termos de teorias simples como o modelo de Demchack e Fort (DF) para o potencial dos filmes de Langmuir, e a teoria de Gouy-Chapman (GC) para a dupla formada na interface filme/subfase. Os resultados também são apresentados no capítulo 2. O m-cresol possui lugar de destaque nos estudos de polianilina, principalmente pelos efeitos de dopagem causados por esse material, como o processo de dopagem secundária [7-9]. As variações observadas na formação das monocamadas e fabricação dos filmes LB devido ao uso desse agente plastificante são mostradas no capítulo 4 . O estudo de novas técnicas que permitam um melhor controle no processo de dopagem da polianilina, incluindo a possibilidade de realizá-la sem o emprego de solventes, é de grande importância e interesse em possíveis aplicações, como os dispositivos citados no início deste capítulo. Resultados da exposição de filmes "casting" de polianilina aos raios-X revelaram um aumento em até dez ordens de grandeza nos valores de condutividade elétrica $[10,11]$. Em vista disto, decidimos verificar tais efeitos nos filmes LB. Os resultados são apresentados no capítulo 5. Os problemas relativos à 
discrepância nos valores de condutividade elétrica em filmes LB de polianilina levaram-nos a uma revisão bibliográfica sobre a fabricação de filmes LB de polianilina, e a realização de medidas a.c. com o intuito de comparar e investigar a quais fatores podem ser atribuídas as diferenças encontradas por diferentes grupos de pesquisa. Os resultados são apresentados no capítulo 6 .

\section{4) Revisão da literatura sobre filmes $L B$ de polianilinas}

A dificuldade inicial de processamento da polianilina (PANi) pura levou ao desenvolvimento de diferentes métodos experimentais que permitissem a aplicação da técnica LB. Uma das primeiras tentativas foi a síntese do polímero sobre a superfície da água [12-15]. Nesse processo o agente oxidante é incorporado na subfase e o monômero espalhado na forma de filme de Langmuir. Entretanto, uma dificuldade inerente a este método é a impossibilidade de eliminar impurezas resultantes do processo de polimerização, e ainda o trabalhoso processo de limpeza da cuba, caso a medida necessite ser interrompida e reiniciada. Em vista disto vários pesquisadores optaram pela derivatização da cadeia polimérica [16-22]. Dessa forma conseguiu-se materiais processáveis em solventes orgânicos voláteis, como clorofórmio e diclorometano, permitindo a formação de monocamadas. O problema com essa abordagem é que a presença de grupos laterais ao longo da cadeia polimérica causa efeitos estéricos, que tem como conseqüência uma piora nas propriedades elétricas do material, quando comparado com o polímero puro $[23,24]$. Tentou-se então uma técnica desenvolvida na década de sessenta por H. Khun [25], que está baseada na mistura de materiais que são difíceis de formar filmes de Langmuir estáveis, como os polímeros conjugados, com ácidos graxos, que sabe-se de antemão serem bons formadores de filmes de Langmuir e LB. Os materiais seriam então misturados em um solvente orgânico volátil e espalhados sobre uma subfase líquida. Moléculas tenso ativas como os ácidos graxos atuam simplesmente como um agente dispersando as moléculas do polímero em pequenos domínios, resultando num filme de Langmuir flexível o suficiente para ser transferido verticalmente. $\mathrm{O}$ resultado global são as moléculas do polímero conjugado dispersas em uma matriz anfifílica. O nível da mistura depende da composição do filme. Com isto vários 
grupos de pesquisa utilizaram diferentes métodos de processamento para obtenção de filmes mistos de polianilina com ácidos graxos [26-31]. Alternativamente tentou-se o uso de diferentes agentes processantes [28-38,44,45] como o N-metilpirrolidinona (NMP), e a utilização de ácidos funcionalizados para o processamento da PANi [3942]. O uso de ácidos funcionalizados melhorou a processabilidade da polianilina, resultando ainda num aumento dos valores de condutividade elétrica $\left(\sim 400{\mathrm{~S} . \mathrm{cm}^{-1}}^{-1}\right.$ em filmes "casting") [7,8,39-42]. Evitaram-se, assim, as dificuldades de síntese na cuba, descartou-se o uso de derivados do polímero, uma vez que possuem propriedades elétricas inferiores ao do material puro [23,24], e eliminou-se a utilização de solventes como o NMP, que é bastante solúvel em água, implicando na possibilidade de perda de material para a subfase líquida. Descobriu-se a partir de então que a utilização de subfases ácidas permite a obtenção de filmes de Langmuir mais estáveis [19-21,29], que acabou permitindo a fabricação de filmes LB de PANi pura e no estado dopado $[5,6,43]$. Os últimos resultados foram muito positivos devido ao seu ineditismo, mas os problemas associados aos baixos valores de condutividade elétrica ainda continuam. Descreveremos a seguir alguns dos resultados mais relevantes na fabricação de filmes Langmuir-Blodgett de polianilinas.

Ando et al [16] estudaram um derivado de polianilina preparado pela polimerização química de 2-octadecoxianilina. O material foi dissolvido em clorofórmio e espalhado em subfase ácida $0,1 \mathrm{M}$ de $\mathrm{HCl}$. Os filmes $\mathrm{LB}$ foram transferidos pelo processo de deposição horizontal. Resultados de difração de raios$\mathrm{X}$, com as deposições ocorrendo apenas na imersão do substrato na subfase, indicaram filmes LB tipo X, com uma distância entre camadas igual a 37 A. Os filmes não dopados apresentaram valores de condutividade elétrica $(\sigma)$ em torno de $10^{-9}$ a $10^{-11} \mathrm{~S}^{-\mathrm{cm}^{-1}}$. Após exposição ao vapor de iodo a condutividade aumenta para $10^{3}$ e $10^{5}{\mathrm{~S} . \mathrm{cm}^{-1}}^{-1}$ com variação de cor dos filmes.

Mello et al [19-21] fizeram um extensa caracterização sobre a formação de monocamadas de um derivado da PANi, a poli(o-etoxianilina) (POEA). É feita a referência da obtenção de filmes mais estáveis sobre subfases ácidas. Filmes LB tipo Y são obtidos sobre o quartzo, enquanto filmes LB tipo $\mathrm{Z}$ são obtidos sobre o vidro. 
A condutividade elétrica dos filmes dopados foi medida pelo método de van der Pauw, apresentando valores de $10^{-3} \mathrm{~S}_{\mathrm{cm}}{ }^{-1}$.

Paddeu at al [22] realizaram uma análise das variações conformacionais induzidas na cadeia polimérica dos filmes de Langmuir de poli(o-anisidina) (POMA) através de variações de $\mathrm{pH}$ da subfase, utilizando para isto ácido clorídrico $(\mathrm{HCl})$. Os filmes foram caracterizados por medidas de pressão de superfície, microscopia no ângulo de Brewster (BAM), e por UV-vis. Observaram uma diminuição nos valores de área por molécula com o aumento de acidez na subfase, sugerindo que a presença de dopante na subfase aumenta a densidade superficial da monocamada causando variações conformacionais no polímero, que por sua vez influenciará a organização das moléculas no filme LB de diferentes maneiras. As imagens de BAM indicam que as monocamadas formadas sobre subfases ácidas $(\mathrm{pH}=1)$ apresentam regiões não homogêneas que vão diminuindo à medida que o filme de Langmuir é comprimido. As monocamadas formadas sobre água ultrapura apresentam pequenos domínios que se agregam e formam domínios maiores durante a compressão. Concluíram que as alterações do filme com a subfase líquida possui uma forte influência sobre a organização das moléculas, e ainda que a utilização de subfases ácidas é um processo eficiente para a protonação do polímero, embora valores de condutividade maiores tenham sido alcançados com a exposição dos filmes LB ao $\mathrm{HCl}$.

Punkka et al [29] trabalharam com derivados de polianilina, poli(Ndecilanilina) e uma mistura fornada de polianilina, 3-octadecanoilpirrol e ácido dodecil benzenossulfônico (DBSA). Resultados de elipsometria indicaram uma espessura de $19 \AA$ por camada. Os valores de condutividade elétrica variaram de $10^{-9}$ a $10^{-7}$ S.cm ${ }^{-1}$.

Cheung et al [27] processaram polianilina em NMP e clorofórmio na presença de ácido esteárico, para fabricação de filmes mistos tipo $\mathrm{Y}$, ou seja, as deposições nesse caso ocorrem na subida e na descida do substrato na subfase líquida. Resultados de difração de raios-X indicaram uma distância entre bicamadas de $47 \AA$, consistente com a espessura por camada em torno de $25 \AA$, medida por perfilometria. A condutividade elétrica (van der Pauw) dos filmes dopados em $\mathrm{HCl}$

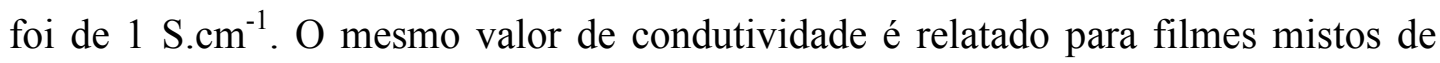
polianilina sulfonada e estearilamina. Em outro trabalho [26] reagiram polianilina 
sulfonada com estearilamina, adicionando-os posteriormente em uma solução de benzeno com sulfóxido de dimetila. Estimaram um espaçamento entre bicamadas de $32 \AA$, com os filmes de multicamadas apresentando condutividade elétrica da ordem

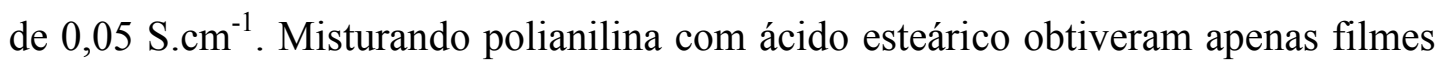

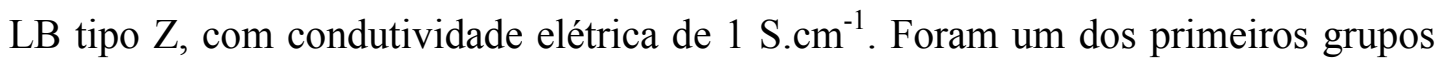
de pesquisa a relatar que abaixando-se o $\mathrm{pH}$ da subfase pode-se trabalhar com esse sistema misto em sua forma condutora, embora não apresentem nenhum tipo de medida a esse respeito.

Royappa et al [28] estudaram a fabricação de heteroestruturas de polianilina sulfonada com estearilamina, indicando filmes LB tipo Y. Os resultados de elipsometria forneceram valores de $16 \AA$ por camada, com valores de índice de refração em torno de 1,5, obtido do ajuste experimental. A difração de raios-X indicou uma distância entre bicamadas próxima a $34 \AA$, ou seja $17 \AA$ por camada, muito próximo ao encontrado por elipsometria. Os filmes desdopados apresentaram valores de condutividade (van der Pauw) em torno de $10^{-6} \mathrm{~S}_{\mathrm{cm}} \mathrm{cm}^{-1}$, enquanto os expostos a ambientes úmidos $10^{-2} \mathrm{~S}_{\mathrm{cm}}{ }^{-1}$.

Suwa et al [30] estudaram filmes mistos de polianilina processada com sulfóxido de dimetila, sendo posteriormente adicionada numa solução de ácido esteárico com clorofórmio. Obtiveram filmes LB tipo Y, com uma deposição menor na descida do substrato. A espessura foi estimada entre 16 a $18 \AA$ por camada, de acordo com resultados elipsométricos. Citam que a remoção do ácido esteárico do filme LB pode ser feita imergindo-se o filme numa solução de n-hexano e clorofórmio.

Dhanabalan et al [31] estudaram filmes mistos de polianilina processada com NMP e ácido araquídico. Durante os estágios iniciais de deposição (seis primeiras camadas) os filmes LB eram tipo $\mathrm{Y}$, mas com o aumento do número de camadas depositadas o caráter tipo $\mathrm{Z}$ acaba predominando. Um filme LB tipo $\mathrm{Z}$ é aquele no qual as deposições se dão apenas na retirada do substrato da subfase. Os resultados de difração de raios-X indicaram uma distância entre bicamadas de 56 A. A condutividade elétrica dos filmes dopados, medida pelo método de quatro pontas, foi de $0,9 \mathrm{~S}_{\mathrm{cm}}{ }^{-1}$. Processaram ainda PANi na presença de ácido acético e NMP, sem a presença de clorofórmio [32]. Observaram que com a diminuição do valor de $\mathrm{pH}$ da 
subfase há um aumento nos valores de área molecular média e uma diminuição na compressibilidade total da monocamada. Relatam novamente a obtenção de filmes tipo $\mathrm{Y}$ nas primeiras deposições, predominando, posteriormente, filmes tipo $\mathrm{Z}$ com TRs entre 0,8 e 0,9 . A TR (do inglês "transfer ratio") é a razão entre a área do substrato a ser coberta com filme e o decréscimo de área da monocamada durante a deposição, fornecido pelo movimento das barreiras na cuba de Langmuir. A espessura por camada foi estimada como sendo de $35 \AA$. Os filmes desdopados apresentaram valores de condutividade elétrica (quatro pontas) em torno de $10^{-4}$ $\mathrm{S} . \mathrm{cm}^{-1}$. Já os filmes expostos ao vapor de $\mathrm{HCl}$ indicaram valores em torno de 0,1 S.cm ${ }^{-1}$

Ram et al [33,34] estudaram filmes de PANi processada em NMP e clorofórmio, variando a percentagem entre esses dois solventes. Os filmes LB obtidos foram tipo $\mathrm{Y}$, embora tenham observado uma alteração para filmes tipo $\mathrm{Z}$ acima de 24 camadas depositadas.

Agbor et al [35] utilizaram ácido acético para processar a polianilina em NMP e clorofórmio. Os filmes obtidos eram tipo Z apresentando-se muito uniformes por inspeção visual. Resultados de elipsometria indicaram espessuras de 56 a $61 \AA$ para cada camada depositada. A condutividade elétrica foi medida pelo método de duas pontas, no mesmo plano da amostra, em vácuo. Os filmes desdopados

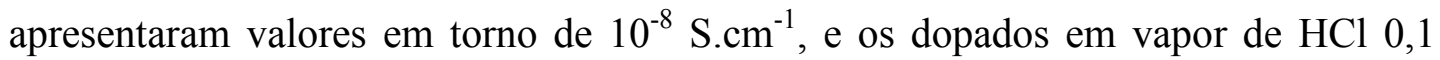
${\mathrm{S} . \mathrm{cm}^{-1}}^{-1}$ Sugerem que as cadeias poliméricas estejam alinhadas perpendicularmente à direção de deposição. Utilizaram, também, apenas NMP para processar a PANI, fabricando o filme LB sobre um eletrodo interdigitado na construção de um sensor de gás [37]. Os valores relatados para a espessura e condutividade dos filmes LB foram os mesmos citados acima.

K. Ramanatham et al [38] processaram a PANi com NMP e clorofórmio, adicionando posteriormente à subfase a enzima de glucose oxidase para a fabricação de um biossensor.

Porter et al [44] realizaram medidas de microscopia de força atômica em filmes LB de polianilina processada com ácido acético e NMP. Inferiram um valor de $55 \AA$ de distância entre camadas subsequentes na estrutura do filme LB. Não foi verificado nenhum tipo de anisotropia nas medidas de condutividade elétrica, 
realizadas pelos métodos de duas e quatro pontas, indicando uma condutividade de $0,1 \mathrm{~S}_{\mathrm{cm}} \mathrm{cm}^{-1}$. Citam que a condutividade macroscópica da polianilina é severamente limitada pela necessidade de aprisionamento ou tunelamento dos portadores de carga entre as regiões não condutoras que separam volumes adjacentes. No caso de filmes LB, qualquer produto químico utilizado para processar a polianilina poderia degradar a condução de um domínio para outro, resultando numa diminuição da condutividade volumétrica do material.

Lavrik et al [45] adicionaram polianilina com um derivado fosforilatado de calix[4]resorcinolareno (CA) em NMP e clorofórmio. Obtiveram filmes LB tipo Y com uma espessura por camada de $16 \AA$, obtida por elipsometria. A condutividade

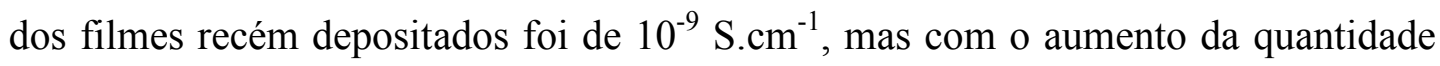
adicionada de CA ocorrem acréscimos nos valores de condutividade. $\mathrm{O}$ objetivo da fabricação desse tipo de filme era a formação de nanoestruturas para a fabricação de um sensor de gás.

Riul et al [5] utilizaram ácidos funcionalizados, $m$-cresol e clorofórmio de diferentes maneiras para processar a PANi, utilizando subfases ácidas para formação das monocamadas. Obtiveram filmes LB tipo $\mathrm{Z}$ de polianilina no seu estado dopado. Em outro trabalho [6] verificaram que a ordem em que esses agentes processantes são adicionados causa variações no espectro de UV-vis devido a variações conformacionais das cadeias poliméricas. A condutividade elétrica (van der Pauw), no entanto, não é afetada, apresentando um valor em torno de $10^{-4} \mathrm{~S}_{\mathrm{cm}}{ }^{-1}$. Ocorre uma exceção expondo o filme LB ao vapor de $m$-cresol, havendo efeito de anisotropia com um aumento de duas ordens de grandeza no valor de condutividade elétrica. Resultados de AFM indicaram uma orientação nas cadeias poliméricas na forma de fibrilas de 60 a $160 \mathrm{~nm}$ de largura.

Granholm et al [43] utilizaram o mesmo procedimento adotado por Riul et al para processar a PANi, utilizando também subfases ácidas para formação das monocamadas. Adicionaram cloreto de potássio $(\mathrm{KCl})$ para aumentar o grau de dopagem do polímero sem afetar o valor do $\mathrm{pH}$ da subfase. Estimaram uma espessura de $25 \AA$ por camada nos filmes LB a partir de espectros de absorção óptica. Em outro trabalho [46], utilizando os procedimentos citados acima, realizaram estudos de condutividade elétrica no filmes LB em função da espessura, 
temperatura e do campo elétrico aplicado. A condutividade cresce com a espessura, mas satura após poucas camadas terem sido depositadas (aproximadamente sete). A condutividade volumétrica foi estimada em torno de $10^{-3}{\mathrm{~S} . \mathrm{cm}^{-1}}^{-}$e a baixos campos aplicados os filmes indicaram uma dependência do tipo $\ln \sigma \propto \mathrm{T}^{-1 / 2}$, onde $\mathrm{T}$ é a temperatura absoluta. Esse grupo de pesquisa finlandês tem se destacado ainda na fabricação de dispositivos emissores de luz, através da montagem de heteroestruturas de filmes LB de PANi, utilizando os procedimentos relatados acima, com filmes LB de derivados de tiofeno $[47,48]$.

De uma análise dos resultados mencionados nesta seção conclui-se que não há um consenso na literatura a respeito dos valores de condutividade elétrica e espessura por camada em filmes LB de polianilina, obtidos por diferentes métodos experimentais e grupos de pesquisa. A espessura por camada na literatura varia de 14 a $34 \AA$ quando obtida por difração de raios-X, e de 16 a $61 \AA$ quando obtida por elipsometria. Os valores de condutividade elétrica, obtidos pelos métodos de duas e quatro pontas, para os filmes LB desdopados, variam de $10^{-11}$ a $10^{-4} \mathrm{~S}_{\mathrm{cm}} \mathrm{cm}^{-1}$, enquanto que para os filmes LB de PANi dopados em vapor de $\mathrm{HCl}$ os valores encontrados estão no intervalo de $10^{-4}$ a $0,1 \mathrm{~S}_{\mathrm{cm}} \mathrm{cm}^{-1}$. Ainda assim, valores de espessura em torno de 25 a $30 \AA$, por camada depositada, e de condutividade em torno de 0,1 a $1 \mathrm{~S} . c m^{-1}$ são os mais freqüentes obtidos por diferentes grupos de pesquisa. 


\section{CAPÍTULO 2}

\section{2) Caracterização dos filmes de Langmuir de Polianilinas}

\section{1) Filmes mistos de polianilina e 16-mero com estearato de cádmio}

\subsection{1) Introdução}

Nossas tentativas de formar monocamadas estáveis de polianilina processada com ácido canforssulfônico $(\mathrm{CSA})$ sobre água ultrapura $(\mathrm{pH} \cong 6)$ não foram bem sucedidas. Estudos anteriores mostraram que sobre a água as monocamadas são menos estáveis que quando formadas sobre subfases ácidas [5,6], e os filmes LB formados são visualmente não uniformes. Entretanto, o decréscimo do valor do $\mathrm{pH}$ da subfase aumenta consideravelmente a estabilidade da monocamada [5,6,19-21], persistindo, contudo, a não uniformidade dos filmes LB produzidos.

No caso dos filmes mistos de PANi com ácido esteárico (Ast) as monocamadas formadas sobre água são estáveis, mas para isto é necessário adicionar íons de cádmio na subfase para aumentar a estabilidade do Ast [49]. Em subfases com valor de $\mathrm{pH}$ menor que quatro o ácido esteárico não se dissocia, e sua parte hidrofílica permanece na forma $(\mathrm{COOH})$. Para valores de $\mathrm{pH}$ entre quatro e seis o grau de ionização aumenta e a cabeça polar toma a forma:

$\mathrm{COOH} \leftrightarrow \mathrm{COO}^{-}+\mathrm{H}^{+}$

Adicionando cloreto de cádmio $\left(\mathrm{CdCl}_{2}\right)$ na subfase aquosa tem-se no equilíbrio:

$\mathrm{CdCl}_{2}+2 \mathrm{H}_{2} \mathrm{O} \leftrightarrow \mathrm{Cd}(\mathrm{OH})_{2}+2 \mathrm{HCl}$

ou seja, a formação de uma base fraca $\left(\mathrm{Cd}(\mathrm{OH})_{2}\right)$ e de um ácido forte $(\mathrm{HCl})$ diminui o pH da subfase $(\cong 4,8)$ e, consequentemente, o grau de ionização do ácido esteárico. Por isso adiciona-se bicarbonato de sódio $\left(\mathrm{NaHCO}_{3}\right)$ na subfase, onde no equilíbrio tem-se:

$\mathrm{NaHCO}_{3}+\mathrm{H}_{2} \mathrm{O} \leftrightarrow \mathrm{NaOH}+\mathrm{H}_{2} \mathrm{CO}_{3}$ 
$\mathrm{O} \mathrm{NaOH}$ é uma base forte e o $\mathrm{H}_{2} \mathrm{CO}_{3}$ um ácido fraco, aumentando o valor do $\mathrm{pH}$ da subfase, que fica com o valor próximo de seis. Assim, o grau de ionização do ácido volta a aumentar. Nessa situação os íons de cádmio ficam complexados às partes hidrofílicas $\left(\mathrm{COO}^{-}\right)$do ácido esteárico, formando estearato de cádmio $(\mathrm{CdSt})$, melhorando assim as características de deposição dos filmes LB.

Baseados nos resultados obtidos com a PANi, realizamos estudos sobre a formação de monocamadas mistas de um oligômero de PANi (16-mero) com ácido esteárico, nas mesmas condições descritas para a polianilina.

\subsection{2) Parte Experimental}

\subsubsection{1) Soluções de PANi}

A polianilina foi quimicamente sintetizada como descrito na referência [50], apresentando uma massa molar em torno de $10^{4} \mathrm{~g} / \mathrm{Mol}$. Ácido canforsulfônico (CSA, 99\%) e ácido esteárico (99\%) foram adquiridos da Aldrich, e clorofórmio (grau HPLC) da Merck. Adicionamos polianilina, CSA e ácido esteárico (Ast) em clorofórmio, deixando a solução no ultrassom por aproximadamente uma hora. Devido à presença de partículas em suspensão, provavelmente PANi de alta massa molar, a solução foi filtrada antes de ser usada. Optou-se pela não utilização de $m$ cresol, apesar do aumento de solubilidade quando comparado ao CSA, porque algumas vezes, durante o processamento do polímero, verificou-se ainda assim a presença de partículas em suspensão na solução final, sendo necessária a filtragem. Essa diferença em solubilizar completamente a PANi algumas vezes, e em outras não, em $m$-cresol se deve a efeitos de oxidação que o polímero sofre com o tempo. A quantidade de Ast foi mantida constante em $1 \mathrm{mg}$ e diferentes quantidades de polianilina foram adicionadas.

\subsubsection{2) Soluções de 16-mero}

O 16-mero foi sintetizado quimicamente por Feng na Universidade da Pensilvânia (EUA), como descrito nas referências [51,52]. Diferentes composições de 16-mero e ácido esteárico foram misturadas com ácido canforssulfônico (CSA), clorofórmio $\left(\mathrm{CHCl}_{3}\right)$ e $m$-cresol, como descrito para a PANi no item anterior. A 
solução final é obtida após trinta minutos em um banho de ultrassom. Em seguida a solução tornou-se completamente homogênea não sendo necessário filtrá-la, ao contrário do que ocorria com a PANi. Foram misturadas diferentes quantidades de 16-mero e ácido esteárico, mantendo-se fixa a quantidade de $m$-cresol utilizada (1 $\mathrm{mL}$ ) para eliminar possíveis efeitos devidos à variação na quantidade desse agente plastificante.

A razão molar utilizada entre polianilina (e 16-mero) e CSA corresponde a $50 \%$ de dopagem do polímero e do oligômero. Utilizamos como subfase água ultrapura, obtida de um sistema Milli-Q, na qual foi adicionado cloreto de cádmio $\left(4.10^{-4} \mathrm{M}\right) . \mathrm{O} \mathrm{pH}$ da subfase foi mantido constante, em torno de seis, adicionando-se bicarbonato de sódio, como descrito anteriormente. As monocamadas foram comprimidas com velocidades de $10 \mathrm{~mm} / \mathrm{min}$. Nos cálculos de área molecular média (A) consideramos apenas a massa molar de Ast. Portanto, qualquer mudança nas curvas de pressão de superfície (П) em função da área molecular média (П X A) seria atribuída devido à adição de diferentes quantidades de PANi e 16-mero na solução de ácido esteárico.

\subsection{3) Caracterização dos filmes de Langmuir}

\subsubsection{1) Pressão de superfície}

Apresentamos na Figura 2 as curvas ( $\Pi \mathrm{X} \mathrm{A}$ ) de monocamadas mistas de polianilina e estearato de cádmio. As curvas ( $\Pi$ X A) das monocamadas mistas contendo estearato de cádmio com diferentes porcentagens de 16-mero são mostradas na Figura 3. Verifica-se em ambos os casos que à medida que as quantidades de PANi e 16-mero são aumentadas na solução que forma a monocamada, a curva de pressão correspondente apresenta uma maior compressibilidade que a do estearato de cádmio puro. A área é calculada levando-se em conta apenas as moléculas de ácido esteárico, ou seja, A nas Figs 2 e 3 é a área por molécula de ácido. A curva ( $\Pi$ X A) de estearato de cádmio é caracterizada por um aumento brusco na pressão de superfície próximo a $20 \AA^{2}$, indicando a formação de uma monocamada estável e condensada. A ausência da região líquido-expandida, normalmente observada com o ácido esteárico, está relacionada à complexação dos 
grupos polares do Ast com os íons de cádmio na subfase, formando o sal de estearato. De certa forma, para elevadas percentagens de polímero e oligômero, adicionadas em solução, o caráter polimérico torna-se predominante $\mathrm{e}$ as monocamadas passam a ser menos estáveis e condensadas que a apresentada pelo CdSt.

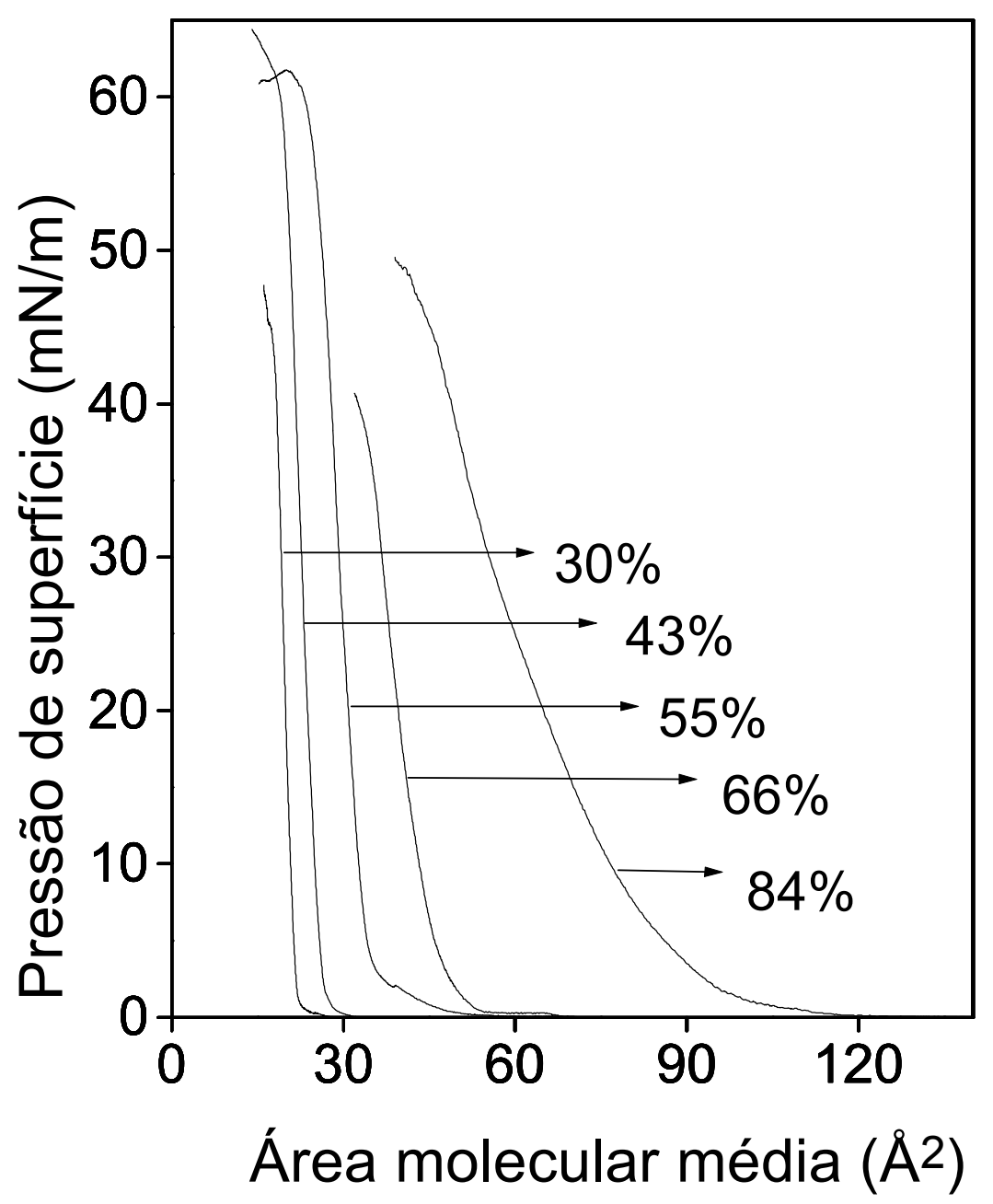

FIGURA 2 - Curvas de pressão de superficie para as monocamadas mistas de polianilina com estearato de cádmio em diferentes composições de PANi.

As monocamadas mistas contendo de 20 a 55\% de polianilina são estáveis, uma vez que não foi notado um decréscimo significativo no valor de área molecular quando as monocamadas eram comprimidas até uma pressão de $25 \mathrm{mN} / \mathrm{m}$ e mantidas nesse valor de pressão durante pelo menos uma hora. Escolhemos esse valor de pressão por ser próximo daquele utilizado na fabricação dos filmes LB (aproximadamente $29 \mathrm{mN} / \mathrm{m}$ ). Durante várias compressões observamos apenas uma pequena histerese entre a primeira compressão e as compressões subseqüentes. 


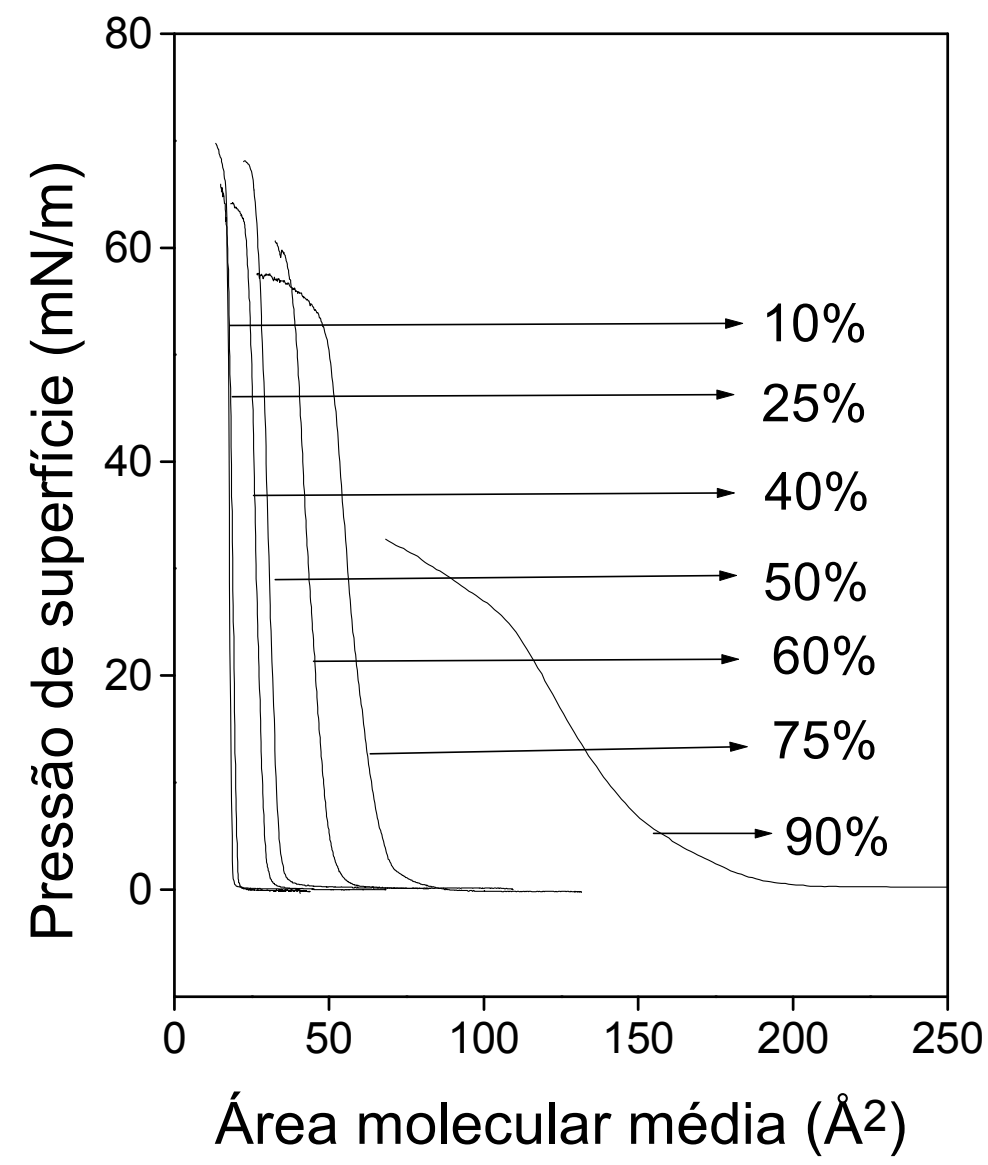

FIGURA 3 - Curvas de pressão de superficie para as monocamadas mistas de 16-mero com estearato de cádmio em diferentes composições de 16-mero.

Como pode ser verificado na Figura 3, uma monocamada mista condensada pode ser obtida com uma quantidade próxima a 60\% de 16-mero na solução, acima da qual os filmes de Langmuir exibem uma isoterma expandida [49]. Nos filmes de Langmuir mistos contendo até 60\% de 16-mero há uma pequena histerese nas curvas de pressão após várias compressões da monocamada. Com 90\% de oligômero na solução a curva (П X A) correspondente é bastante expandida, sem apresentar uma região condensada bem definida. A pressão de colapso para as monocamadas mistas de 16-mero está na faixa de 60 a $65 \mathrm{mN} / \mathrm{m}$, próxima da pressão de colapso do estearato de cádmio puro, indicando que as características de estearato de cádmio persistem com a adição de até $60 \%$ (em massa) de 16-mero na solução. Acima de 60\% de 16-mero, há um decréscimo no valor da pressão de colapso na monocamada mista. O mesmo comportamento não é observado nas monocamadas mistas de polianilina, pois nestas últimas a pressão de colapso é independente da 
composição. Embora haja variações nos dois casos analisados, elas não são sistemáticas. A boa reprodutibilidade, em compressões sucessivas, das curvas (П X A), em ambos os casos, garante que não há dissolução de material na subfase.

Os valores limites de máxima compressão desses filmes mistos, obtidos extrapolando-se a parte condensada da curva ( $\Pi$ X A) até o eixo correspondente aos valores de área molecular média, aumentam abruptamente quando a percentagem de polianilina ou 16-mero ultrapassa um determinado valor, fato este observado na diferença de comportamento de estabilidade das monocamadas. Isso é ilustrado nas Figuras 4 e 5 a seguir. Na Fig. 5 é mostrada também a variação da área crítica para o conjunto de curvas de potencial de superfície, que serão discutidas mais à frente na seção 2.1.3.2, em função da variação da percentagem em massa de 16-mero na solução.

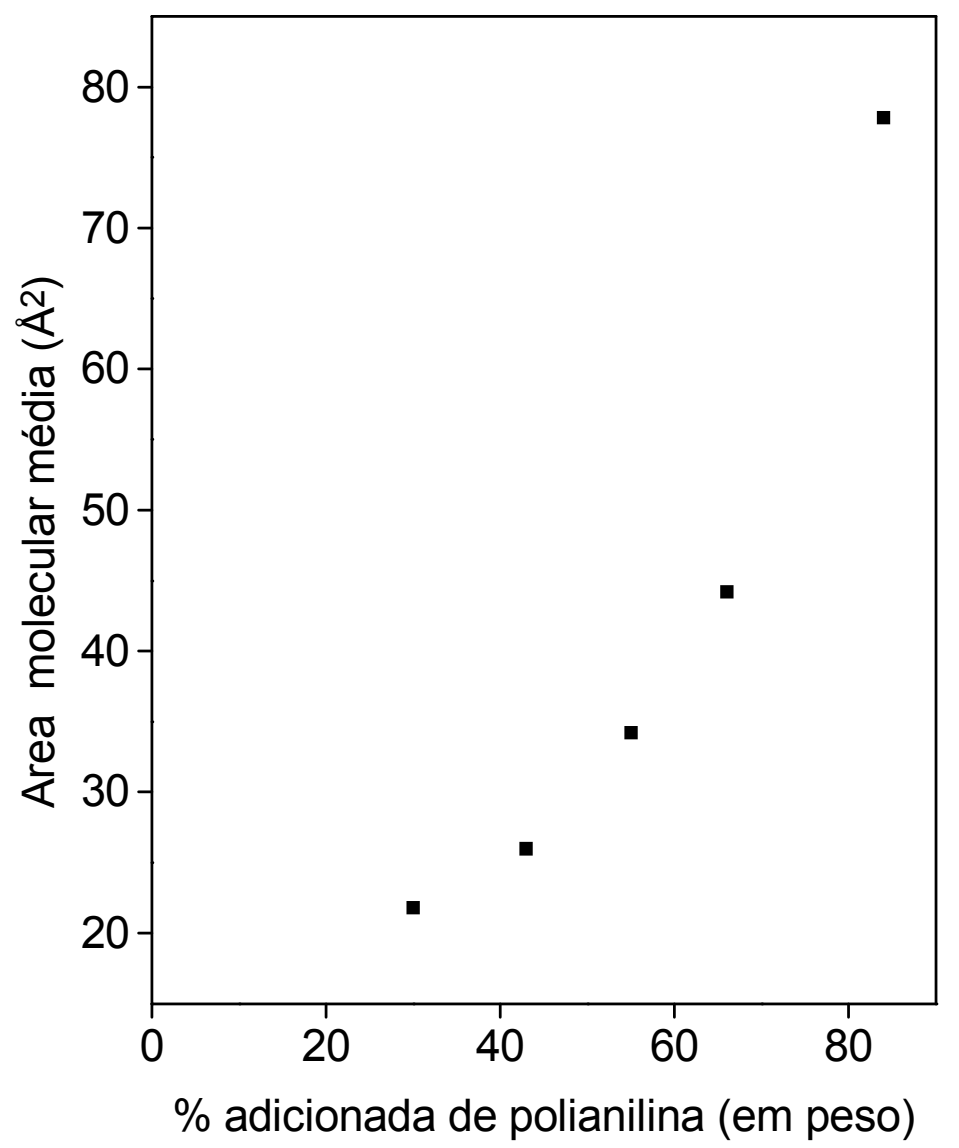

FIGURA 4 - Variação da área molecular por molécula de ácido, em função da percentagem de polímero nas monocamadas mistas de PANi/CdSt. 


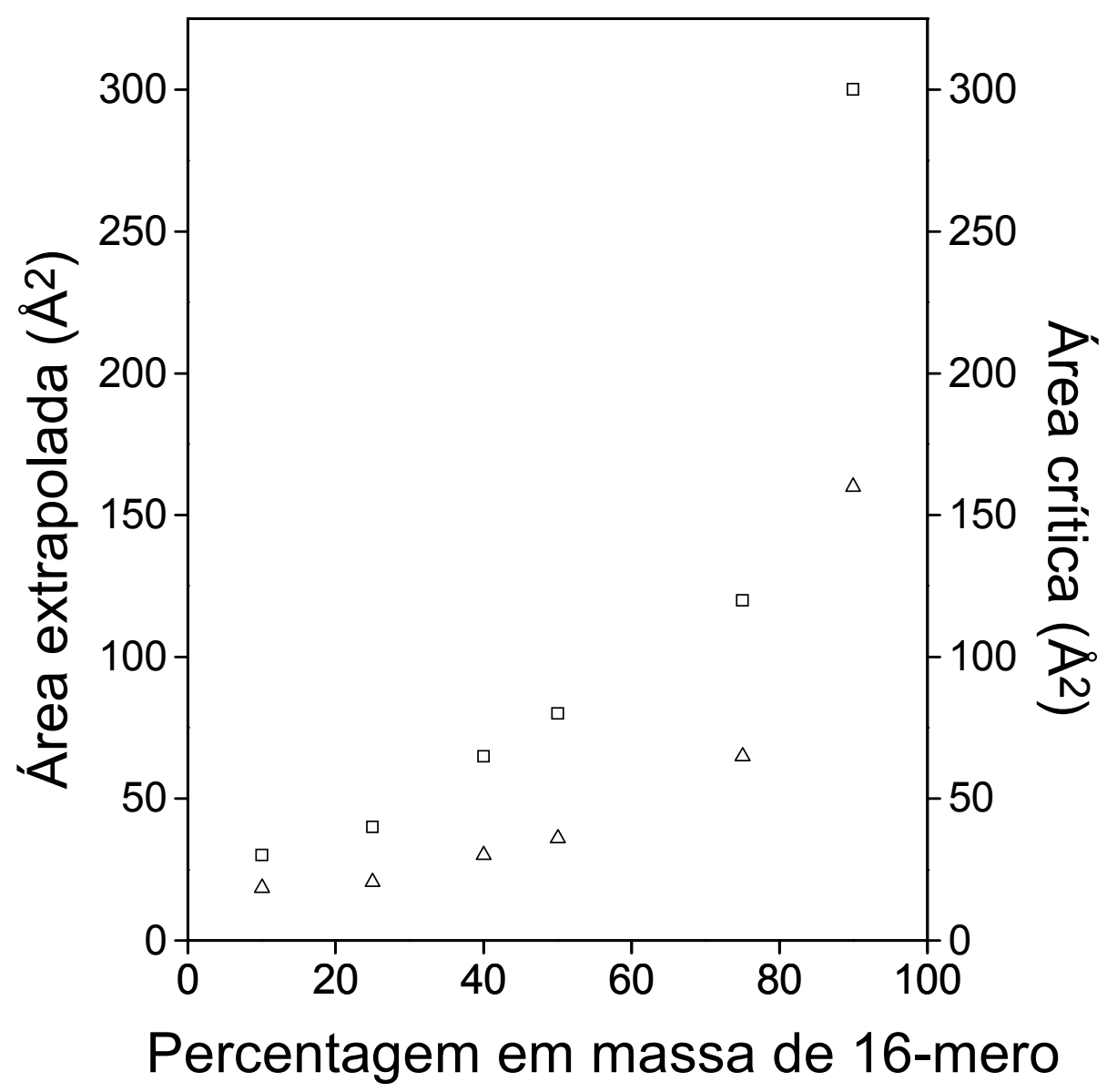

FIGURA 5 - Variação da área molecular média (4), extrapolada das curvas (ПX A), e da área crítica ( ), obtida das curvas ( $\triangle V X A)$, em função da variação da percentagem, em massa, de 16-mero na solução.

Apenas para efeito de comparação, foi calculada a área molecular média em função da massa molar média de polianilina, ou 16-mero (unidade repetitiva), com estearato de cádmio. A variação desses valores de área em função da variação da percentagem utilizada de PANi ou 16-mero na solução, para formação das monocamadas mistas, é mostrada nas Figuras 6 e 7. Como pode ser notado esses valores calculados de área molecular decrescem quase que linearmente com o aumento da quantidade de material polimérico, obedecendo à conduta aditiva simples de mistura [53]. Tal comportamento é normalmente relacionado com a formação de domínios separados dos dois componentes, não havendo mistura em nível molecular [27]. 


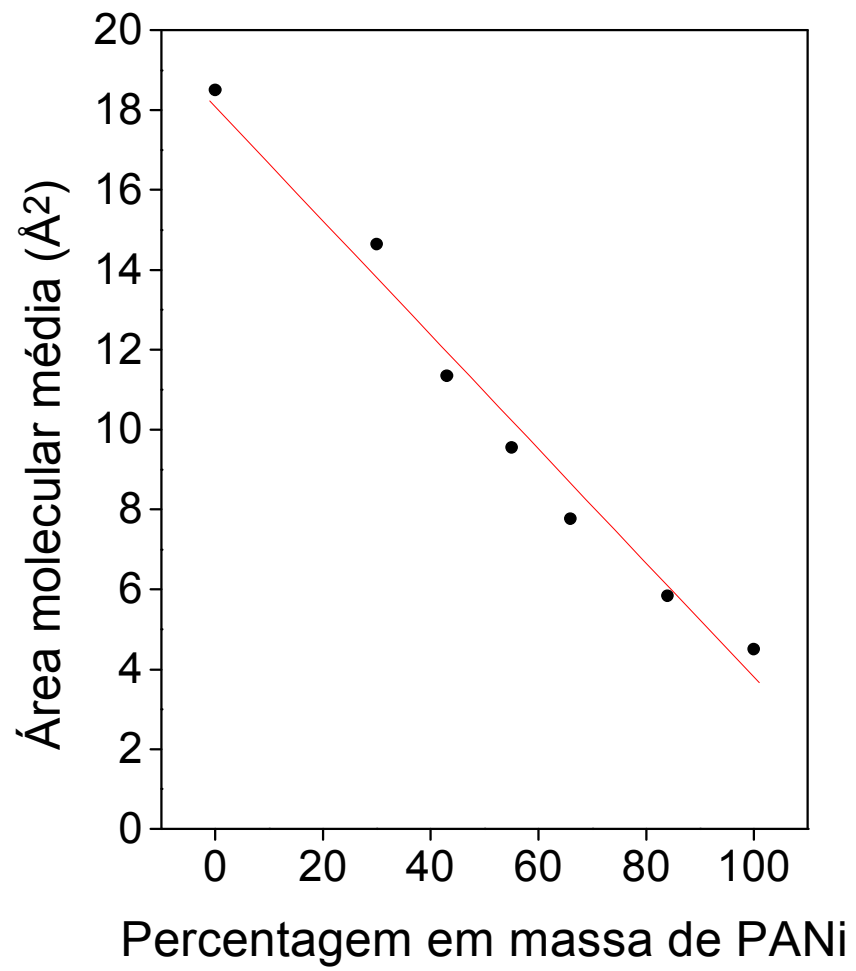

FIGURA 6 - Variação da área molecular, calculada em função da massa molar média de PANi e ácido esteárico, para diferentes percentagens de polímero na solução.

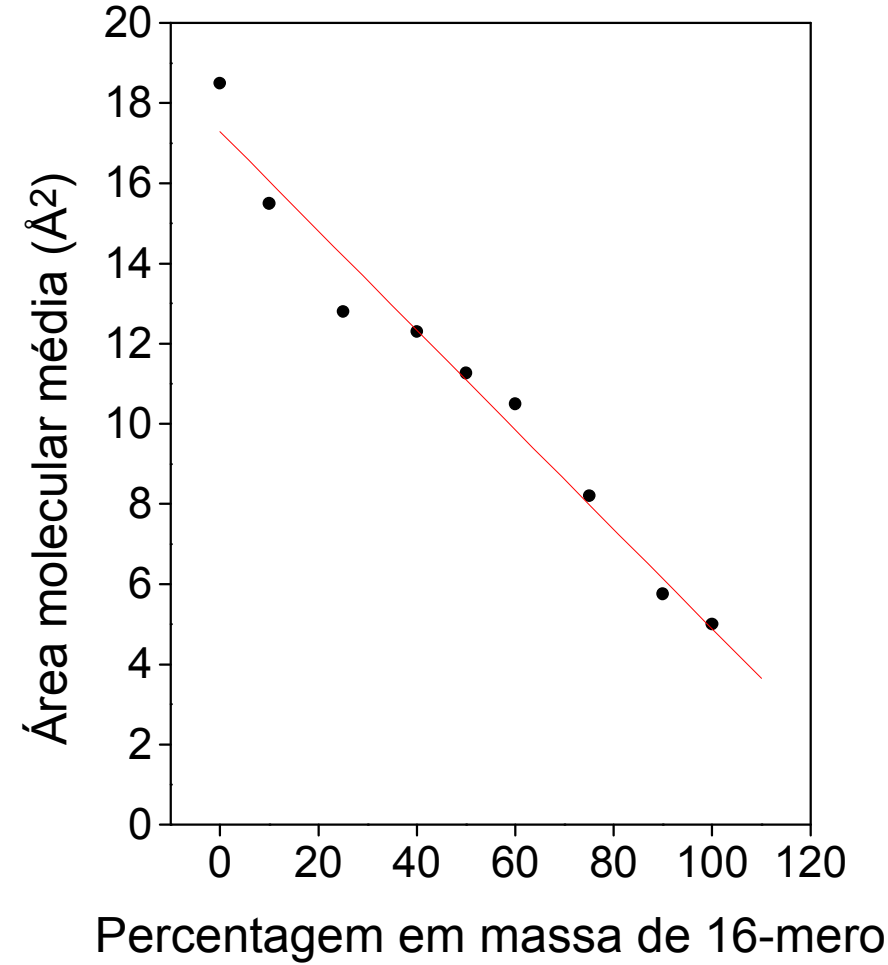

FIGURA 7 - Variação da área molecular, calculada em função da massa molar média de 16-mero e ácido esteárico, para diferentes percentagens de oligômero na solução, utilizadas para formação de monocamadas mistas de 16-mero/CdSt. 
A estabilidade dos filmes mistos de 16-mero com estearato de cádmio é mostrada na Figura 8 para as diferentes porcentagens utilizadas. Deve-se notar nesta figura que os valores de $\mathbf{A}$, mantendo-se $\Pi$ constante em $29 \mathrm{mN} / \mathrm{m}$, são diferentes para as diferentes quantidades de oligômero adicionadas. Todas as curvas foram colocadas juntas para ressaltar a variação que ocorre nos valores iniciais de área em cada um dos casos estudados. Na Fig. 8 verifica-se que uma monocamada mista é estável quando até $60 \%$ de oligômero são adicionados. Acima desta porcentagem nota-se um decréscimo acentuado nos valores de área, mantendo-se a monocamada comprimida em $29 \mathrm{mN} / \mathrm{m}$. Nos casos dos filmes mistos contendo de $60 \%$ a $75 \%$ de 16-mero, as monocamadas ficam estáveis após uma hora de compressão. Por isso, nestes filmes, o processo de deposição teve início apenas após a monocamada ficar comprimida por pelo menos uma hora. O filme de Langmuir com 90\% de 16-mero não se estabilizou mesmo após longo tempo de espera, e por isso não se tentou realizar a transferência dessa monocamada para um substrato sólido.

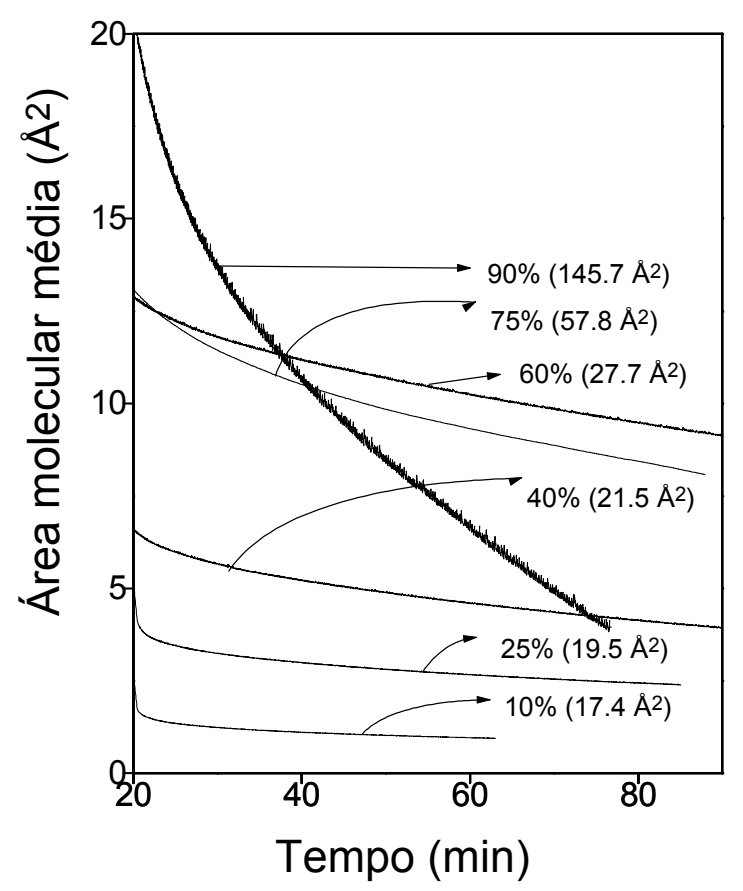

FIGURA 8 - Curvas de estabilidade das monocamadas mistas de 16-mero/CdSt nas diferentes percentagens utilizadas.

O decréscimo observado na estabilidade desses filmes mistos (Fig. 8) mostra claramente que suas características são governadas pela quantidade adicionada de polímero ou oligômero (acima de 60\%). O decréscimo da estabilidade pode estar associado à "expulsão" das moléculas de PANi ou 16-mero do filme de Langmuir 
quando a monocamada é mantida comprimida em valores elevados de pressão de superfície [54,55].

\subsubsection{2) Potencial de superfície}

O potencial de superfície $(\Delta \mathrm{V})$, por ser uma medida mais sensível que a de pressão de superfície, pode fornecer mais informações sobre os filmes de Langmuir. Ele pode ser diretamente relacionado aos momentos de dipolo dos grupos polares de moléculas simples, usando o modelo de Demchack e Fort (DF) [56]. No caso de as moléculas serem ionizáveis deve-se levar em conta a contribuição da dupla camada elétrica formada na interface filme/subfase, usando o modelo de Gouy-Chapman (GC) [56,57]. Entretanto, no caso de materiais poliméricos, mais especificamente das polianilinas, as correlações que são feitas nos modelos DF e GC para moléculas simples, como os ácidos graxos, não podem ser feitas devido às dificuldades em se determinar as contribuições dipolares desses materiais poliméricos. Mesmo assim, uma análise qualitativa das medidas de potencial serve para verificar a possível formação de agregados sobre a subfase.

Mostramos na Figura 9 as curvas de potencial de superfície em função da área molecular média ( $\triangle \mathrm{V}$ X $\mathrm{A})$ das monocamadas mistas de PANi e estearato de cádmio, contendo diferentes quantidades de polímero. A Fig.10 mostra os resultados de $(\Delta \mathrm{V}$ X A) dos filmes mistos de 16-mero com CdSt.

No caso de moléculas simples como os ácidos graxos, o potencial de superfície é próximo de zero quando o filme de Langmuir está completamente expandido, correspondendo a grandes valores de área por molécula, e à medida que a monocamada é comprimida nota-se um aumento do $\Delta \mathrm{V}$ a partir de um determinado valor de área molecular, denotado como área crítica (Ac), que usualmente é próximo do dobro do valor da área média que cada molécula ocupa sobre a subfase no estado condensado (A) [56]. Com os filmes mistos de polianilina e 16-mero observamos um valor de $\Delta \mathrm{V}$ não nulo imediatamente após espalhar a monocamada, independentemente da quantidade de material espalhado sobre a subfase, indicando que há formação de agregados ("ilhas") do filme de Langmuir, ou seja a formação de domínios, antes mesmo de a monocamada ser comprimida. Sob compressão, ocorre 
um aumento no potencial de superfície a partir do valor de área crítica, que geralmente é o dobro do valor de A. Esse tipo de comportamento é similar àquele observado em moléculas anfifílicas típicas.

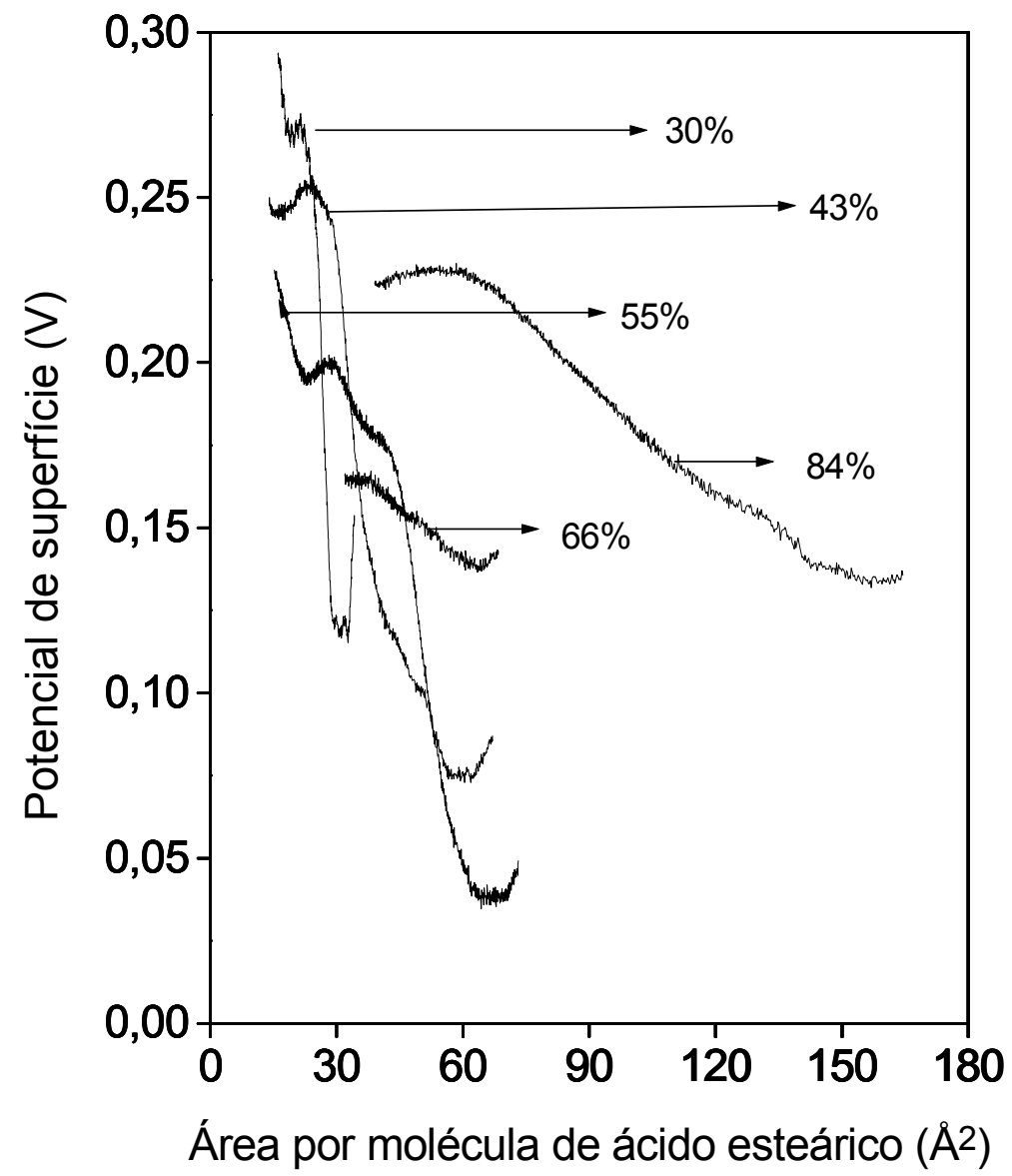

FIGURA 9 - Curvas de potencial de superfície em função da área por molécula para diferentes percentagens de PANi nas monocamadas mistas.

Geralmente com o aumento da quantidade de PANi (de 66\% a 84\%) o patamar máximo da curva de potencial decresce. Exceto para as misturas com percentagens de polímero muito alta ou muito baixa, o valor máximo atingido pelo potencial de superfície $\left(\mathrm{V}_{\mathrm{m}}\right)$ decresce com o aumento da quantidade de polímero adicionada. A variação nas curvas $(\triangle \mathrm{V} X \mathrm{~A})$ com o aumento da quantidade de PANi na solução, mantendo-se fixa a quantidade de ácido esteárico (adicionada em solução), indica claramente que o processo de organização molecular varia com a quantidade adicionada de polímero nos filmes de Langmuir mistos. 


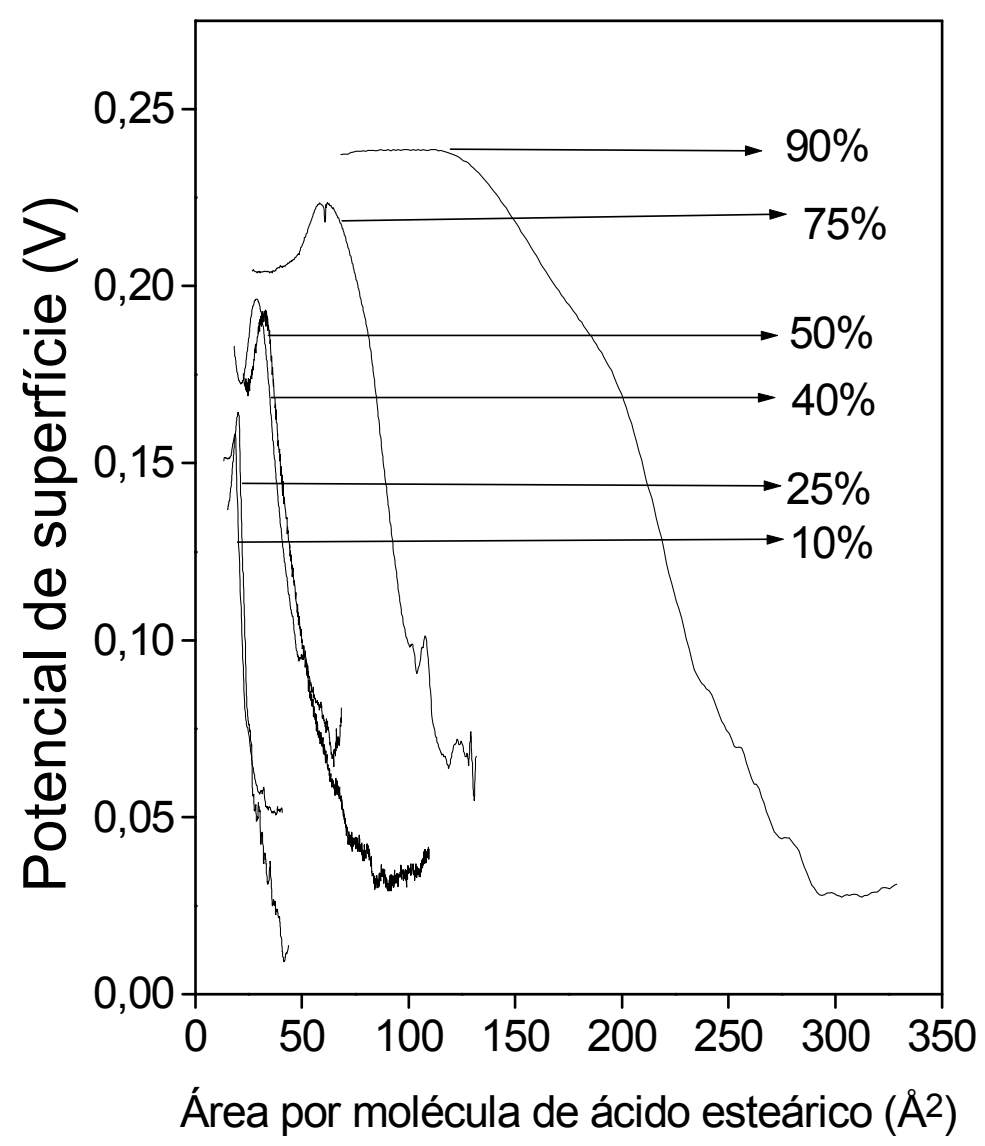

FIGURA 10 - Curvas de potencial de superfície em função da área por molécula para diferentes percentagens de 16-mero nas monocamadas mistas.

Como observado nos filmes mistos de PANi, independentemente da composição do filme de Langmuir, há um acréscimo de 70 a $90 \mathrm{mV}$ no $\Delta \mathrm{V}$ durante o espalhamento do material sobre a subfase, permanecendo posteriormente de 30 a 60 $\mathrm{mV}$ após meia hora ou mais de descanso da monocamada. Geralmente com monocamadas contendo até $50 \%$ de oligômero observa-se uma subida íngreme nas curvas de potencial de superfície. Entretanto, com o aumento da quantidade de 16mero essa subida na curva de potencial torna-se mais suave. O valor máximo atingido pelo potencial de superfície durante a compressão do filme de Langmuir aumenta com a quantidade de 16-mero na monocamada mista, ao contrário do que ocorre com a polianilina.

De qualquer forma, os resultados apresentados anteriormente mostram claramente que, tanto nos filmes mistos de PANi quanto nos filmes mistos de 16mero, a organização das monocamadas está relacionada com a quantidade de 
polímero (ou oligômero) adicionado em solução para formação dos filmes de Langmuir.

\section{2) Efeito de protonação nas monocamadas, devido à variação do $\mathrm{pH}$ na subfase, verificado pelo potencial de superficie dos filmes de Langmuir de polianilinas.}

\subsection{1) Introdução}

Desde a década de oitenta tornou-se possível relacionar as medidas de potencial de superfície $(\Delta \mathrm{V})$ com os momentos de dipolo associados aos grupos moleculares, especialmente para compostos alifáticos simples [56]. Isto tem sido feito empregando-se o modelo de Demchack e Fort (DF) [56] no qual $\Delta V$ é expresso por :

$$
\Delta V=\frac{1}{A \varepsilon_{0}}\left(\frac{\mu_{1}}{\varepsilon_{1}}+\frac{\mu_{2}}{\varepsilon_{2}}+\frac{\mu_{3}}{\varepsilon_{3}}\right)+\Psi_{0}
$$

Nessa expressão, A é o valor de área ocupada por uma molécula e $\boldsymbol{\varepsilon}_{0}$ é a permissividade elétrica do vácuo. Em $\mu_{1} / \varepsilon_{1}$ estão incorporadas a polarização e reorientação das moléculas da subfase devido à presença da monocamada, $\mu_{2}$ é a contribuição dipolar da parte hidrofílica e $\mu_{3}$ da parte hidrofóbica de moléculas simples. $\boldsymbol{\varepsilon}_{1}$, $\boldsymbol{\varepsilon}_{\mathbf{2}}$ e $\boldsymbol{\varepsilon}_{3}$ são, respectivamente, as constantes dielétricas dos meios nos quais esses momentos de dipolo estão imersos. Em $\boldsymbol{\varepsilon}_{\mathbf{2}}$ e $\boldsymbol{\varepsilon}_{\mathbf{3}}$ incorporam-se, respectivamente, todos os fatores que fazem com que os momentos de dipolo, dos grupos hidrofílico e hidrofóbico, se desviem dos valores que deveriam ter na molécula isolada.

Se a monocamada está ionizada forma-se uma dupla-camada na interface filme/água, que também contribui nas medidas de potencial de superfície. O modelo mais simples para essa contribuição ao $\Delta \mathrm{V}$ é a teoria de Gouy-Chapman (GC) [56], na qual :

$$
\Psi_{0}=\frac{2 k T}{e} \operatorname{senh}^{-1}\left(\frac{e \cdot \alpha}{A\left(5,88 \cdot 10^{-7} \cdot \varepsilon \cdot c \cdot T\right)^{\frac{1}{2}}}\right)
$$


$\Psi_{0}$ é a contribuição da dupla-camada para o potencial de superfície, $d_{\sigma}$ é a densidade superficial de cargas, definida como a razão entre a carga eletrônica $e$ $\left(1,6.10^{-19} \mathrm{C}\right)$ e a área ocupada por cada molécula (A, obtida das curvas de pressão de superfície), $\varepsilon$ a permissividade elétrica da subfase líquida (suposta constante e igual a 78,5), $c$ a concentração iônica da subfase (moles/litro), $k$ constante de Boltzmann $\left(1,38.10^{-23} \mathrm{~J} / \mathrm{K}\right)$, e $T$ a temperatura absoluta (em torno de $290 \mathrm{~K}$ ). No caso em que nem todos os grupos hidrofílicos estão ionizados uma constante de dissociação $(\alpha)$ é inserida. Considerou-se $\alpha$ igual a 0,5 , correspondendo aos $50 \%$ de dopagem dos polímeros.

Esse modelo de GC se baseia nas aproximações de uma superfície plana e de extensão infinita, que não haja penetração de cargas na interface monocamada/subfase, e que os íons na subfase sejam cargas puntiformes, obedecendo ainda à distribuição de Boltzmann. Essa teoria descreve muito bem a variação da densidade de carga com o potencial numa determinada superfície, sem limitações para o valor de $\Delta \mathrm{V}$, explicando com sucesso a ionização de monocamadas de ácidos graxos [56]. Teorias mais sofisticadas, no limite de baixos valores de potencial (Debye-Hückel), e correções que levam em conta o tamanho dos contra íons na subfase para formação da dupla camada (teoria de Stern), permitem correções mais acuradas para as variações de potencial devido a $\Psi_{0}$, com as aproximações pertinentes a cada caso. Mesmo assim optamos pelo modelo GC devido à sua simplicidade.

Nos materiais poliméricos é impossível estimar valores para $\mu_{1}, \mu_{2}$ e $\mu_{3}$ devido à complexidade das macromoléculas envolvidas, principalmente porque muitas vezes o polímero está sujeito a diferentes condições de dopagem, que causam modificações estruturais na cadeia polimérica, alterando a contribuição dipolar resultante associada à macromolécula. Como o polímero num meio ácido sofre efeitos de dopagem, que por sua vez está relacionada à presença de cargas ao longo da cadeia polimérica, utilizamos as relações expressas nas equações (4) e (5) para verificar como a contribuição dipolar resultante é afetada nesses materiais pela variação dos valores de $\mathrm{pH}$ em subfases obtidas com diferentes ácidos, partindo do pressuposto que a relação de Gouy-Chapman é valida. A validade dessa suposição será discutida mais tarde. A comparação de monocamadas espalhadas em diferentes 
condições experimentais pode dar informações a respeito de mudanças no grau de dopagem.

Estudamos o efeito do $\mathrm{pH}$ e do tipo de ácido utilizado na subfase, através de curvas de potencial de superfície em função da área por monômero, tanto para a polianilina quanto para a poli(o-etoxianilina) (POEA).

\subsection{2) Parte experimental}

A polianilina foi processada com CSA, m-cresol e clorofórmio conforme descrito na seção 2.1.2. Como a POEA é facilmente solúvel em uma grande variedade de solventes orgânicos voláteis, utilizamos diclorometano no seu processamento. Em alguns experimentos as soluções de POEA/diclorometano foram pré-dopadas com CSA, antes de serem espalhadas sobre as subfases ácidas. A quantidade de CSA, utilizada na pré-dopagem da POEA, corresponde aos 50\% de dopagem para esse polímero. As concentrações das soluções de PANi/clorofórmio e POEA/diclorometano foram de $0,05 \mathrm{mg} / \mathrm{mL}$, permitindo uma comparação com estudos anteriores realizados para a POEA [21,58]. As subfases ácidas foram preparadas a partir de água ultrapura obtida de um sistema Milli-Q, com os seguintes ácidos: $\mathrm{HCl}, \mathrm{HClO}_{4}, \mathrm{H}_{2} \mathrm{SO}_{4}, \mathrm{CF}_{3} \mathrm{COOH}$, para obter diferentes valores de $\mathrm{pH}(4,3,2$ e 1). Em alguns casos, utilizamos água pura como subfase, e, em outros, $\mathrm{pH}$ zero, que corresponde a uma solução ácida 1,0 M. Os experimentos foram realizados numa cuba KSV 5000 de compressão simétrica, dotada de uma prova de Kelvin para medir $\Delta \mathrm{V}$. O volume de solução espalhada foi de $500 \mu \mathrm{L}$ e a velocidade de compressão das barreiras foi de $30 \mathrm{~mm} / \mathrm{min}$. Após espalhar a solução sobre a subfase esperamos um intervalo de tempo de 15 minutos para permitir o espalhamento completo da monocamada e a evaporação do solvente. O trabalho experimental relatado nessa seção foi realizado conjuntamente com a doutoranda Sarita V. Mello, que tem trabalhado com POEA.

\subsection{3) Resultados}

A compressão dos polímeros (PANi e POEA) não dopados, espalhados sobre subfases de água ultrapura, não resulta em filmes de Langmuir satisfatórios, o que é comprovado pelas isotermas ( П X A) irregulares obtidas. A estabilidade dos filmes 
de Langmuir sobre subfases aquosas é uma questão importante para a fabricação de filmes LB de alta qualidade. A importância da dopagem para formar monocamadas estáveis está associada ao ordenamento que é induzido na cadeia polimérica, um resultado que é bem conhecido para a PANi [59].

Os efeitos da dopagem sobre a formação dos filmes de Langmuir dos polímeros estudados podem ser ilustrados pelas Figuras 11 e 12, nas quais se verifica a variação do valor máximo atingido pelo potencial de superfície $\left(V_{m}\right)$ em função da concentração da subfase ácida, para os diferentes tipos de ácido.

Nota-se nessas figuras a presença de dois efeitos: um no qual o valor máximo atingido pelo potencial de superfície inicialmente cresce com o aumento da concentração ácida, e depois decresce monotonicamente; e outro em que $\mathrm{V}_{\mathrm{m}}$ decresce monotonicamente a partir de $10^{-4} \mathrm{M}$. No primeiro caso a monocamada polimérica pode ainda estar sendo dopada pelo aumento de concentração da subfase ácida, que aumentará $\Psi_{0}$ e poderá causar variações na conformação molecular, também influenciando o valor de $\Delta \mathrm{V}$ medido. No segundo caso o polímero pode estar completamente dopado, mesmo em $10^{-4} \mathrm{M}$, e a dopagem protônica poderia não ser influenciada pelas variações do $\mathrm{pH}$ da subfase. Neste segundo caso, se supusermos o polímero completamente dopado não haverá variações na densidade superficial de cargas $\left(d_{\sigma}\right)$. Assim, através da equação (5), nota-se que o potencial de superfície da dupla camada diminuirá com o aumento da concentração ácida (c) da subfase, diminuindo a contribuição de $\Psi_{0}$ para o $\Delta \mathrm{V}$.

O decréscimo monotônico no valor máximo atingido pelo potencial de superfície $\left(\mathrm{V}_{\mathrm{m}}\right)$ com o aumento da concentração, observado nas Fig. 11a, 11c, 12a e $12 \mathrm{~b}$, indica que a partir de $10^{-4} \mathrm{M}$ a monocamada já tenha atingido o nível máximo de dopagem. Esse decréscimo é verificado na relação direta entre $\Psi_{0}$ e a concentração $(c)$, pressupondo que $d_{\sigma}$ não varie na equação 5 . Em outras figuras, especialmente as Fig 11b, 11d, 12c e 12d, $V_{m}$ não decai muito e em alguns casos até aumenta no intervalo de $10^{-4}$ a $10^{-3} \mathrm{M}$, para depois começar a diminuir com o aumento de concentração. Baseados na suposição acima de a monocamada estar completamente dopada, o que se verifica é que o $\mathrm{HClO}_{4}$ parece ser mais eficaz que o $\mathrm{HCl}$ na dopagem da POEA e da PANi, através de subfases ácidas (observar nas 
Figuras 11 e 12). Com este ácido a característica de decréscimo monotônico é a mesma para os dois materiais.

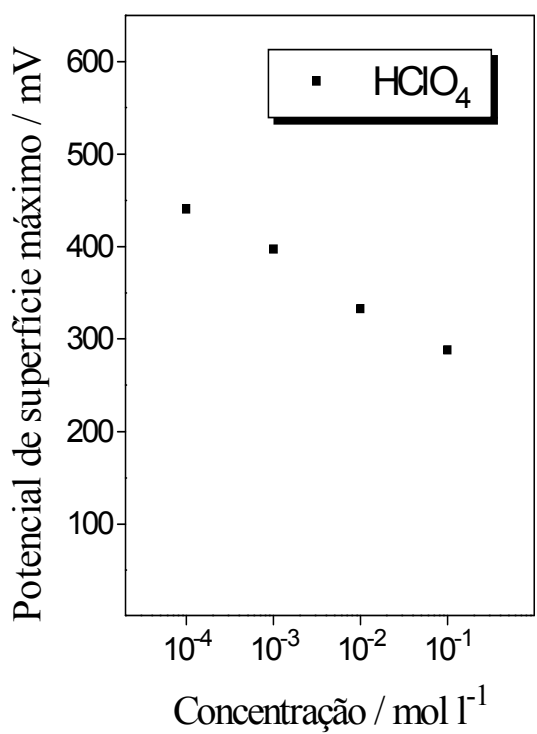

(a)

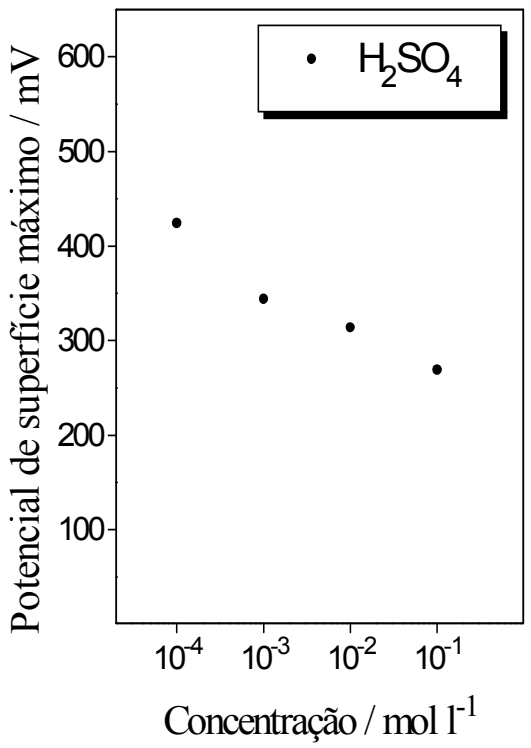

(c)

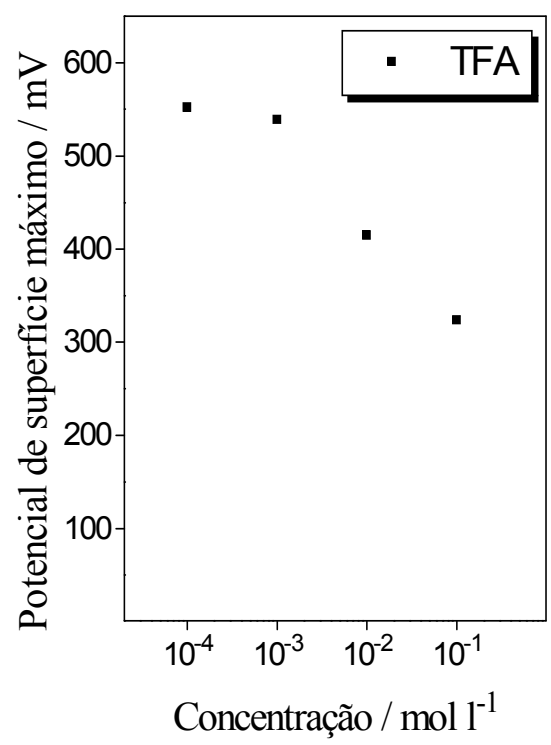

(b)

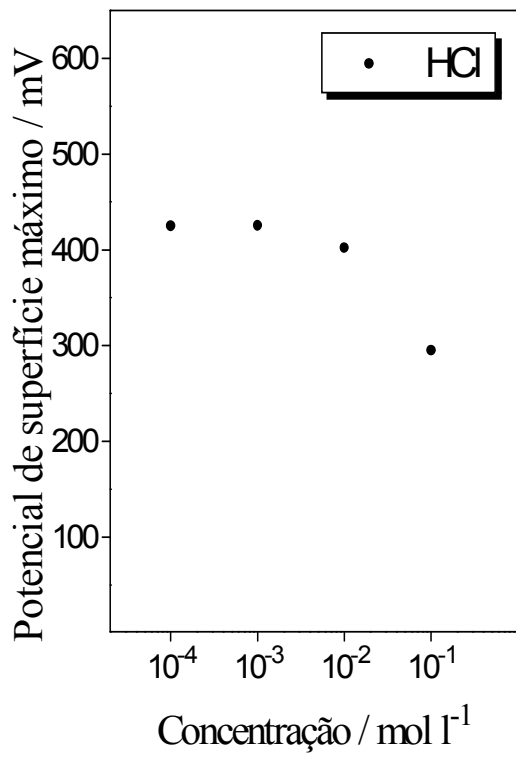

(d)

FIGURA 11 - Variação do valor máximo atingido pelo potencial de superfície nos filmes de Langmuir de PANi, em função da dopagem através de subfases ácidas. (a) $\mathrm{HClO}_{4}$; (b) $\mathrm{CF}_{3} \mathrm{COOH}$; (c) $\mathrm{H}_{2} \mathrm{SO}_{4}$; (d) $\mathrm{HCl}$. 


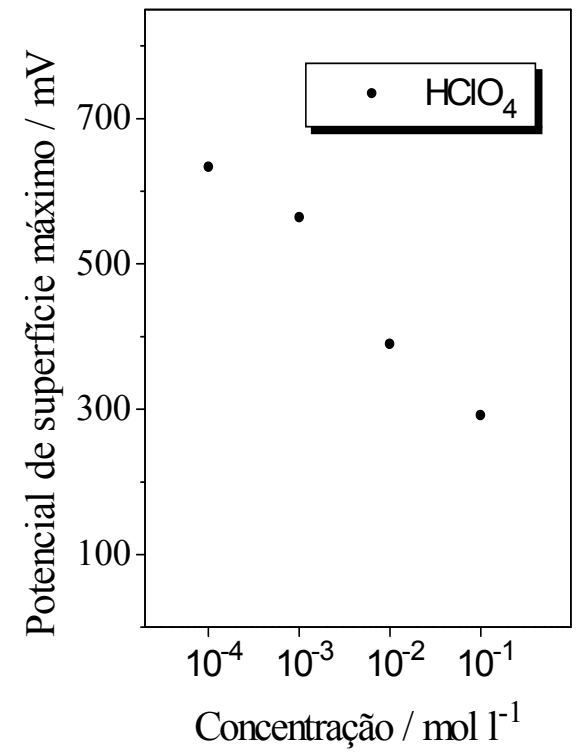

(a)

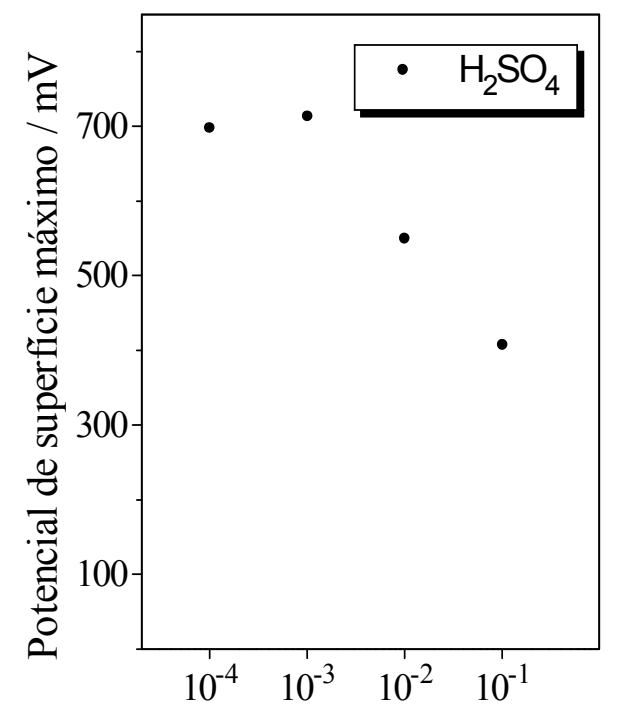

Concentração / mol $1^{-1}$

(c)

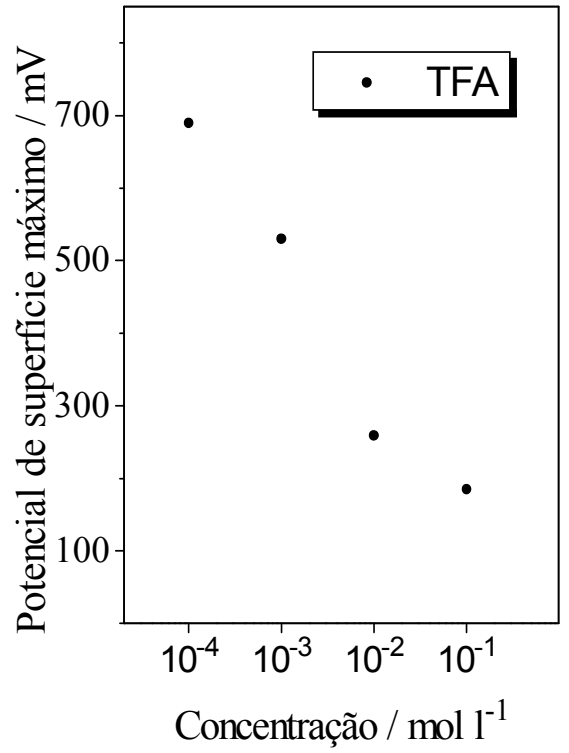

(b)

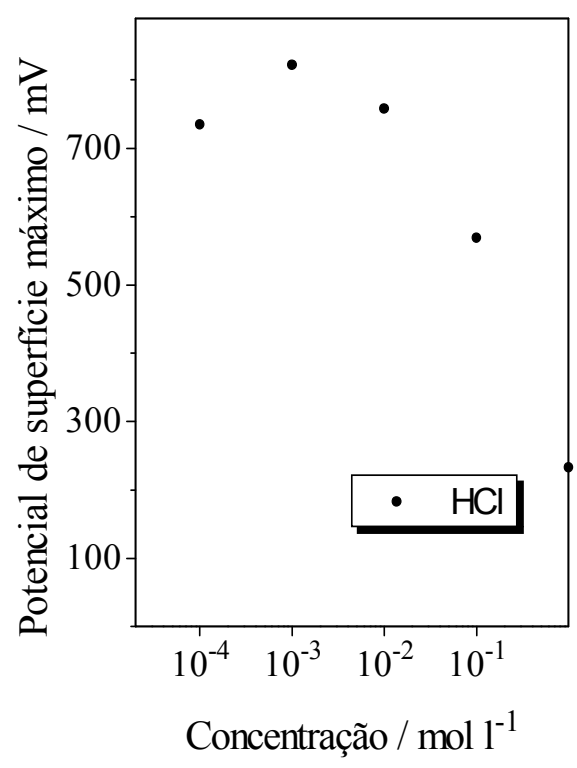

(d)

FIGURA 12 - Variação do valor máximo atingido pelo potencial de superfície nos filmes de Langmuir de POEA, em função da dopagem através de subfases ácidas.(a) $\mathrm{HClO}_{4}$; (b) $\mathrm{CF}_{3} \mathrm{COOH}$; (c) $\mathrm{H}_{2} \mathrm{SO}_{4}$; (d) $\mathrm{HCl}$.

O principal fator para variações no ordenamento e organização dessas moléculas poliméricas é o nível de dopagem, fato que foi evidenciado nos estudos de estabilidade dos filmes de Langmuir de PANi e POEA [5,6,19-21]. 
O nível de dopagem e o ordenamento molecular da PANi em $10^{-1} \mathrm{M}$ parece não depender muito do tipo de ácido utilizado na subfase (Fig. 13), e $\mathrm{V}_{\mathrm{m}}$ permanece no intervalo de 250 a $300 \mathrm{mV}$. Para a POEA, ocorre o inverso, como poder ser observado na Fig. 14, e, $\mathrm{V}_{\mathrm{m}}$ acaba dependendo fortemente do tipo de ácido que forma a subfase. A POEA pré-dopada possui um comportamento similar ao apresentado pela PANi (Fig. 15), ou seja, uma variação de $150 \mathrm{mV}$ no potencial de superfície para o intervalo de $\mathrm{pH}$ utilizado de 1 a 4 . Uma vez que o polímero foi dopado previamente em solução, os efeitos de dopagem causados pelas subfases ácidas acabam sendo menores. Isso deve ser devido a uma possível saturação no processo de protonação dos polímeros.

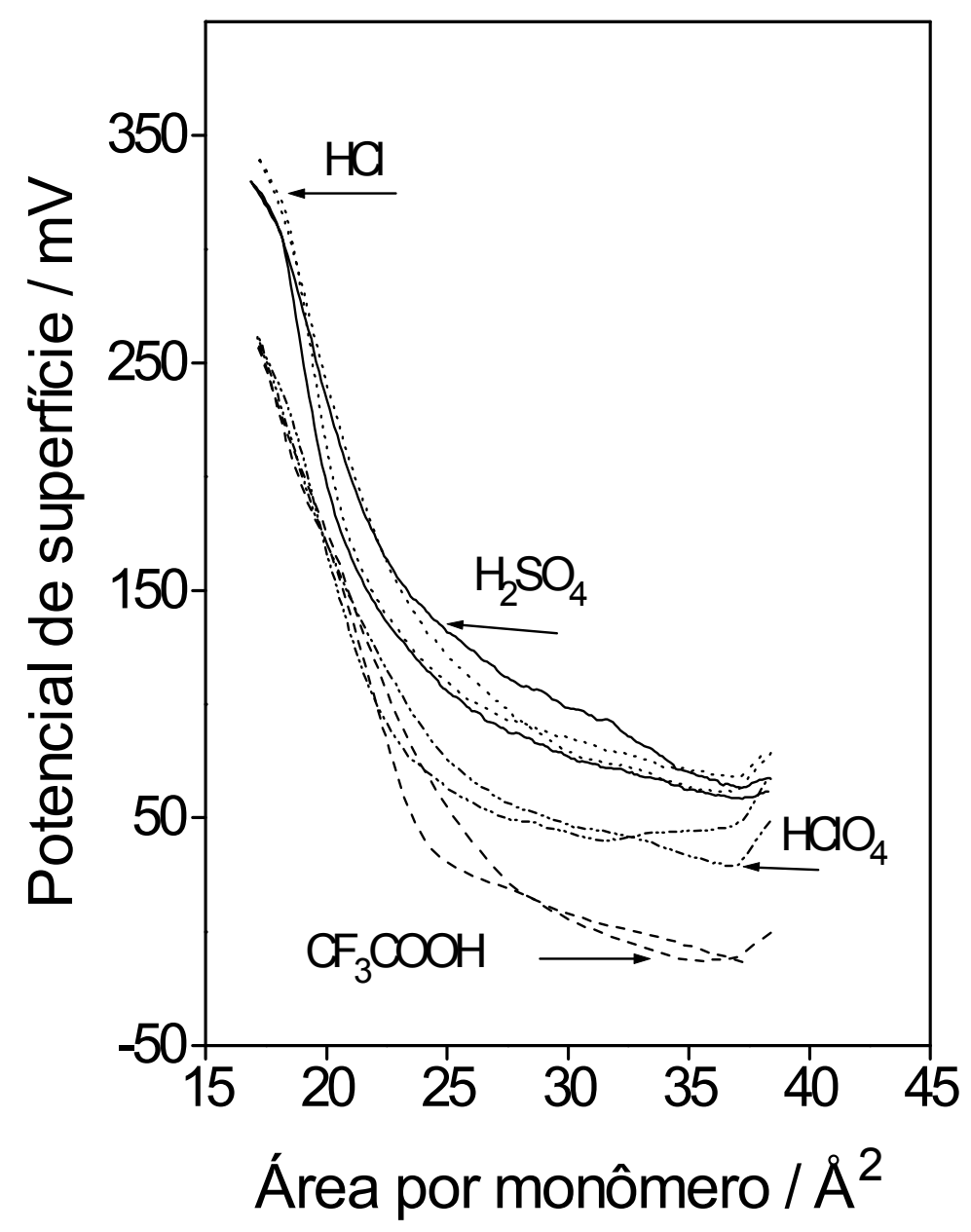

FIGURA 13 - Variação do potencial de superficie para a PANi para um valor fixo de $p H$, em função do ácido utilizado na subfase. 


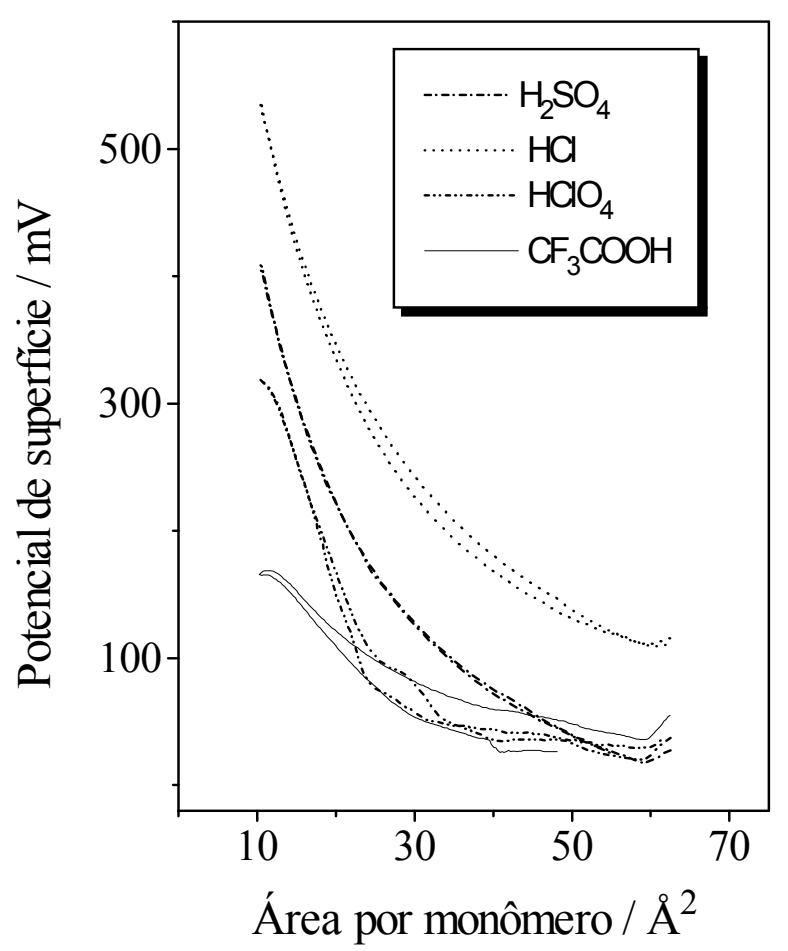

FIGURA 14 - Variação do potencial de superfície para a POEA para um valor fixo de pH, em função do ácido utilizado na subfase.

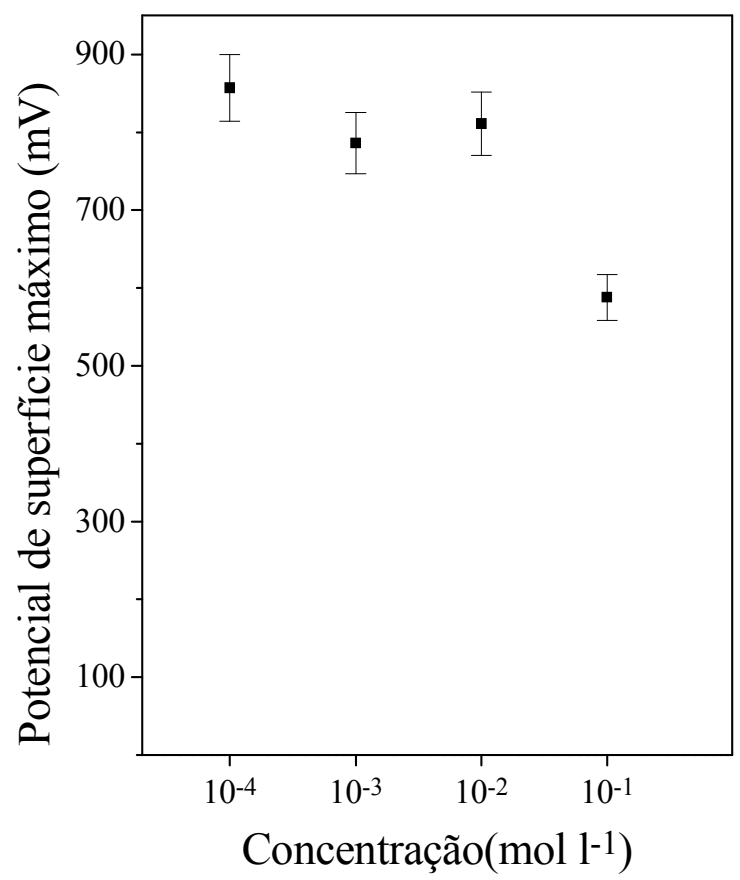

FIGURA 15 - Variação do valor máximo atingido pelo potencial de superfície nos filmes Langmuir de POEA pré-dopada, em função da dopagem através de subfase ácida $\left(\mathrm{HClO}_{4}\right)$. 
Como é razoável supor que as mudanças no potencial com a dopagem sejam somente devido à contribuição de $\Psi_{0}$, é possível estimar quantitativamente esses valores.

Para verificar qual efeito é predominante montamos algumas tabelas para realçar a diferença no comportamento entre a PANi e a POEA. Nessas tabelas $\mathrm{A}_{\text {ext }}$ é o valor de área por monômero, correspondendo ao máximo empacotamento das moléculas obtido, extrapolado das curvas ( $\Pi \mathrm{X} A$ ). $\mathrm{V}_{\mathrm{m}}$ é a média dos valores máximos obtidos das medidas de potencial de superfície, $\Psi_{0}$ a contribuição da dupla camada, calculada a partir da equação (5), e $\mathrm{V}_{0}$ é o valor estimado para a contribuição dipolar a partir de $\mathrm{V}_{\mathrm{m}}$ e $\Psi_{0}$. Os valores de $\mathrm{A}_{\text {ext }}$ são expressos em $\AA^{2}$, e os valores de $\mathrm{V}_{\mathrm{m}}, \mathrm{V}_{0}$ e $\Psi_{0}$ em milivolts $(\mathrm{mV})$. A partir dos valores obtidos experimentalmente de $\mathrm{V}_{\mathrm{m}}$, subtraímos os valores calculados para $\Psi_{0}$ pela equação (5), e estimamos a contribuição de $\mathrm{V}_{0}$. Se o grau de dopagem não for afetado pelo aumento da concentração de ácido na subfase, porque o polímero já estaria completamente dopado em $\mathrm{pH}=4$, toda a variação no potencial de superfície deveria ser atribuída ao decréscimo na contribuição da dupla camada devido ao aumento da concentração. Então, a contribuição dipolar, $\mathrm{V}_{0}$, permaneceria constante, independentemente da mudança na subfase.

Para a PANi, verifica-se na Tabela 1 que $\mathrm{V}_{0}$ permanece numa mesma faixa de valores, ou seja, a contribuição dipolar parece não ser muito afetada por efeitos de dopagem pela subfase. Isto é confirmado pelos valores de $\mathrm{A}_{\text {ext }}$, obtidos das curvas de pressão de superfície, que variam pouco com a mudança do $\mathrm{pH}$ da subfase, indicando que há poucas variações na formação das monocamadas de PANi quando a concentração ácida da subfase é variada. O único caso que parece fugir desse comportamento é em $\mathrm{pH}=4$, para todos os ácidos utilizados. Mas, se supusermos que a monocamada esteja parcialmente protonada, estimando $d_{\sigma}=0,1$, os valores de $\mathrm{V}_{0}$ ficam próximos dos valores apresentados nos $\mathrm{pHs} 1,2$ e 3 . Tal suposição está baseada nos resultados de Focke et all [59] sobre o grau de dopagem da PANi em função do equilíbrio do $\mathrm{pH}$ de uma solução, no qual determinaram que a protonacão decresce para menos de 10\% em valores de $\mathrm{pH}$ maiores que três [59].

Para a POEA, $V_{m}$ decresce abruptamente com o aumento da concentração ácida, principalmente em subfases formadas com ácido trifluoracético $\left(\mathrm{CF}_{3} \mathrm{COOH}\right.$, 
TFA). Neste derivado da polianilina o nível de dopagem varia com o aumento da concentração, afetando drasticamente a formação das monocamadas e consequentemente a contribuição dipolar. O forte efeito de dopagem que a POEA sofre em subfases com TFA é atribuído à presença de átomos de flúor nas moléculas de ácido trifluoracético, que possuem um forte momento de dipolo associado a elas, e parece interferir na conformação molecular do polímero. Isso é confirmado pelas variações nas curvas de pressão de superfície (observar os valores de $\mathrm{A}_{\text {ext }}$ na Tabela 2) quando a concentração ácida é variada. Na Tabela 2 nota-se também que $V_{0}$ varia bastante com a concentração, indicando que a variação em $\Psi_{0}$ devido à mudança na concentração não é a única observada.

As diferenças nos comportamentos entre a PANi e a POEA poderiam ser atribuídas à pré dopagem que a polianilina sofre durante o processamento. No entanto, esta hipótese deve ser descartada uma vez que os resultados da POEA pré dopada com CSA, da mesma forma e na mesma quantidade que a PANi foi, são parecidos com aqueles obtidos com a POEA não pré-dopada quando TFA é utilizado na subfase. Isto é facilmente verificado comparando os valores das tabelas 2 e 3 . Na Tabela 2 não mostramos os resultados para $\mathrm{pH} 2$ e 3 para TFA porque houve discrepâncias nos valores de $\mathrm{A}_{\text {ext }}$. Para a POEA pré dopada (Tabela 3) realizamos as medidas apenas nos extremos de concentração ácida da subfase para testar qual comportamento seria dominante. De novo, nota-se que $\mathrm{V}_{0}$ é bastante diferente para as duas concentrações, como na POEA não pré dopada.

TABELA 1 - Variação do potencial de superfície da PANi em função do $\mathrm{pH}$ da subfase.

\begin{tabular}{|c|c|c|c|c|c|c|c|c|c|c|c|c|c|c|c|c|}
\hline \multirow[b]{2}{*}{$\mathrm{PH}$} & \multicolumn{4}{|c|}{ TFA } & \multicolumn{4}{|c|}{ HCl } & \multicolumn{4}{|c|}{$\mathrm{HClO}_{4}$} & \multicolumn{4}{|c|}{$\mathrm{H}_{2} \mathrm{SO}_{4}$} \\
\hline & $A_{\text {ext }}$ & $\mathrm{V}_{\mathrm{m}}$ & $\mathrm{V}_{0}$ & $\psi_{0}$ & $\mathrm{~A}_{\mathrm{ext}}$ & $\mathrm{V}_{\mathrm{m}}$ & $\mathrm{V}_{0}$ & $\psi_{0}$ & $A_{\text {ext }}$ & $\mathrm{V}_{\mathrm{m}}$ & $\mathrm{V}_{0}$ & $\psi_{0}$ & $A_{\text {ext }}$ & $\mathrm{V}_{\mathrm{m}}$ & $\mathrm{V}_{0}$ & $\psi_{0}$ \\
\hline 1 & 16 & 435 & 267 & 168 & 9,7 & 315 & 121 & 194 & 9.2 & 285 & 89 & 196 & 11 & 280 & 93 & 187 \\
\hline 2 & 17 & 415 & 192 & 223 & 10 & 400 & 150 & 250 & 9.4 & 335 & 81 & 254 & 11 & 320 & 74 & 246 \\
\hline 3 & 17 & 540 & 258 & 282 & 11 & 430 & 124 & 306 & 9.7 & 400 & 89 & 311 & 11 & 360 & 56 & 304 \\
\hline 4 & 19 & 470 & 135 & 335 & 10 & 430 & 62 & 368 & 10 & 440 & 70 & 370 & 11 & 410 & 47 & 363 \\
\hline
\end{tabular}


TABELA 2 - Variação do potencial de superfície da POEA não pré-dopada em função do $\mathrm{pH}$ da subfase.

\begin{tabular}{|c|c|c|c|c|c|c|c|c|c|c|c|c|}
\hline \multirow[b]{2}{*}{$\mathrm{PH}$} & \multicolumn{4}{|c|}{$\mathrm{HCl}$} & \multicolumn{4}{|c|}{$\mathrm{HClO}_{4}$} & \multicolumn{4}{|c|}{ TFA } \\
\hline & $\mathrm{A}_{\mathrm{ext}}$ & $\mathrm{V}_{\mathrm{m}}$ & $\mathrm{V}_{0}$ & $\psi_{0}$ & $\mathrm{~A}_{\mathrm{ext}}$ & $\mathrm{V}_{\mathrm{m}}$ & $\mathrm{V}_{0}$ & $\psi_{0}$ & $\mathrm{~A}_{\mathrm{ext}}$ & $\mathrm{V}_{\mathrm{m}}$ & $\mathrm{V}_{0}$ & $\psi_{0}$ \\
\hline 1 & 12 & 570 & 387 & 183 & 15 & 410 & 239 & 171 & 14 & 185 & 10 & 175 \\
\hline 2 & 14 & 760 & 527 & 233 & 18 & 550 & 330 & 221 & - & - & - & - \\
\hline 3 & 15 & 820 & 532 & 288 & 17 & 715 & 433 & 282 & - & - & - & - \\
\hline 4 & 14 & 735 & 385 & 351 & 21 & 680 & 350 & 330 & 20 & 690 & 358 & 332 \\
\hline
\end{tabular}

TABELA 3 - Variação do potencial de superfície da POEA pré-dopada em função do $\mathrm{pH}$ da subfase.

\begin{tabular}{|c|c|c|c|c|}
\hline \multirow[b]{2}{*}{$\mathrm{pH}$} & \multicolumn{4}{|c|}{ TFA } \\
\hline & $\mathrm{A}_{\text {ext }}$ & $\mathrm{V}_{\mathrm{m}}$ & $\mathrm{V}_{0}$ & $\psi_{0}$ \\
\hline 1 & 16.5 & 229 & 63 & 166 \\
\hline 4 & 18 & 600 & 262 & 338 \\
\hline
\end{tabular}

\subsection{4) Conclusões}

Finalizando o estudo da variação do potencial de superfície com a variação do tipo de ácido utilizado, e do $\mathrm{pH}$ da subfase, concluímos que:

i) A dopagem através de subfases ácidas é essencial para a formação de filmes de Langmuir estáveis de PANi e POEA. Sem monocamadas estáveis é impossível ter controle no processo de fabricação dos filmes LB de polianilinas puras;

ii) Alguns ácidos são mais eficientes que outros no processo de dopagem, e esta eficiência pode estar relacionada com a diferença nos valores de $\mathrm{pKa}$ e na diferença de tamanho dos contra-íons;

iii) as variações em $\Delta \mathrm{V}$, com a composição da subfase, são consistentes com as variações em $\Psi_{0}$ para a PANi;

iv) Para a POEA, especialmente nas subfases contendo TFA, o nível de dopagem continua variando mais que para a PANi com o aumento da concentração ácida da subfase, e as variações em $\Delta \mathrm{V}$ não são exclusivamente devidas à variação em $\Psi_{0}$ causada pela mudança na concentração, uma vez que as contribuições do 
potencial da dupla camada são bem inferiores às variações sofridas pelo potencial de superfície observado;

v) Apesar da complexidade das macromoléculas envolvidas, os resultados da PANi podem ser analisados através de uma teoria simples, utilizando a relação de GouyChapman. Embora haja tratamentos matemáticos mais sofisticados, todos acabam fornecendo resultados similares aos do modelo simplificado de GC no limite de baixas concentrações e densidade de cargas. Dentre esses modelos destacam-se os que consideram tamanhos diferentes de cátions e ânions na subfase [61], ou outros que levam em conta forças de hidratação entre os íons da subfase e a interface na qual a dupla camada é formada [62], fazendo com que na região da dupla camada haja variações na permissividade elétrica ( $\varepsilon$ na equação 5 ), suposta constante no modelo simplificado de GC. Existe também a teoria de Stern [63], que prevê a formação de uma camada de contra-íons, imóveis, adjacente à superfície carregada, que são os filmes de Langmuir no nosso caso. De qualquer forma, o emprego desses tratamentos é não trivial, pois requerem vários parâmetros que não podemos obter experimentalmente. O sucesso da teoria de GC pode, talvez, ser atribuído ao fato de que algumas de suas simplificações, como o tratamento dos contra-íons (da subfase) como cargas puntiformes e a impenetrabilidade da superfície carregada, têm efeitos que se cancelam. 


\section{CAPÍTULO 3}

\section{Caracterização dos filmes $L B$ de polianilinas}

\section{3) Filmes LB mistos de PANi e 16-mero com estearato de cádmio}

\section{1) Introdução}

Nesta seção será apresentado um estudo detalhado de caracterização em filmes LB do sistema composto polianilina/CdSt e 16-mero/CdSt. Devido à excelente uniformidade apresentada por esses filmes mistos, verificada por inspeção visual e medidas de potencial de superfície, aventou-se a possibilidade de haver uma mistura de PANi, ou 16-mero, com CdSt em nível molecular. Resultados de difração de raios-X mostraram claramente, entretanto, que as moléculas desses materiais com estearato de cádmio estão presentes em domínios separados. Os filmes LB fabricados foram caracterizados por difração de raios-X (XRD, do inglês " $X$-ray diffraction"), espectroscopia na região do ultravioleta e do visível (UV-vis), espectroscopia na região do infravermelho (FTIR), elipsometria, microscopia óptica, potencial de superfície e medidas de condutividade elétrica. Para baixa percentagem de polímero, ou oligômero, os difratogramas obtidos são muito similares àqueles de filmes puros de estearato de cádmio. Quando a quantidade de PANi ou 16-mero aumenta, a ordem de empacotamento dos domínios de CdSt é bastante afetada. A presença de PANi e 16-mero com estearato de cádmio nos filmes LB foi também verificada na análise dos resultados de FTIR. A deposição de uma estrutura de multicamadas foi verificada através dos resultados de elipsometria, que forneceram ainda a espessura dos filmes LB analisados, podendo ser comparados com a distância entre bicamadas obtida dos resultados de XRD. A espessura foi dependente da composição do filme. Não foi notada nenhuma variação significativa nos valores de condutividade elétrica nas medidas realizadas tanto no plano (pelo método de van der Pauw) quanto no 
volume (pelo método de duas pontas) ocupado pelos filmes LB, quando se alterava a composição dos filmes mistos.

\section{2) Parte experimental}

As monocamadas de PANi e 16-mero foram transferidas pelo método de deposição vertical, mantendo-se fixa a pressão de superfície em torno de $29 \mathrm{mN} / \mathrm{m}$ durante a deposição, com velocidades de imersão e retirada do substrato na faixa de 1 a $3 \mathrm{~mm} / \mathrm{min}$. Em todos os casos estudados a primeira camada depositada foi mantida fora da subfase por aproximadamente trinta minutos para permitir o escoamento de água do filme para a subfase, o que melhora a adsorção das moléculas sobre o substrato [64]. As camadas depositadas, posteriormente, foram mantidas fora da subfase por apenas cinco minutos. Utilizamos como substratos para a fabricação dos filmes LB vidro b270 puro e metalizado com uma camada de cromo coberta com ouro. O cromo melhora a adesão do ouro no substrato evitando o desprendimento do mesmo na subfase líquida durante o processo de deposição. Nas medidas de FTIR utilizamos seleneto de zinco $(\mathrm{ZnSe})$ e fluoreto de cálcio $\left(\mathrm{CaF}_{2}\right)$ como substratos. As medidas de UV-vis foram realizadas num espectrofotômetro Hitachi, modelo 2001. Os resultados de FTIR foram obtidos num instrumento da BOMEM, série Michelson, com resolução igual a $4 \mathrm{~cm}^{-1}$ para as medidas aqui apresentadas. As medidas de difração de raios-X foram feitas em um difratômetro da Rigaku Rotaflex, modelo RU 200B, que utiliza um alvo de cobre. Os resultados de elipsometria foram obtidos pela Dra. Liliane M. de Souza, em colaboração com o Prof. Edson A. Ticianelli, no Instituto de Química de São Carlos (USP). Para tanto utilizou-se um elipsômetro da Rudolph, modelo S2000. A microscopia óptica foi realizada num microscópio da Olympus, modelo BX40. Os resultados de potencial de superfície foram obtidos através de um voltímetro eletrostático da TREK, modelo 320B. As medidas de condutividade elétrica no plano da amostra foram realizadas pelo método de van der Pauw, e as volumétricas pelo método de dois pontos. Maiores detalhes sobre essas técnicas de medidas são encontrados no capítulo 6. Para tanto foram utilizados uma fonte de corrente da Keithley, modelo 224, e um eletrômetro, também da Keithley, modelo 617. Os contatos utilizados foram fios de ouro de $0,25 \mathrm{~mm}$ de diâmetro, que foram fixados às lâminas contendo os filmes LB com tinta prata. 


\section{3) Fabricação de filmes $L B$}

Uma propriedade interessante a ser investigada é o empacotamento dos filmes transferidos para substratos sólidos. Filmes mistos de PANi e 16-mero com estearato de cádmio foram transferidos pelo método de deposição vertical. $\mathrm{O}$ estearato de cádmio puro geralmente apresenta boas deposições, do tipo Y, ou seja, as deposições se dão tanto na imersão quanto na retirada do substrato na subfase, com valores de TR próximos da unidade [64]. No caso dos filmes de Langmuir de polianilina pura, processada com CSA, os filmes LB são do tipo Z, nos quais as deposições se dão apenas na retirada do substrato da subfase, com TRs no intervalo de 0,6 a $0,8[5,6]$. As monocamadas mistas contendo de $20 \%$ a $44 \%$ de PANi são facilmente transferidas, tipo Y, com TRs próximas da unidade. Com o aumento do número de camadas depositadas (maior que quarenta e cinco) os valores de TR começam a cair. Numa mistura contendo 55\% de PANi em solução, após a deposição de poucas camadas nota-se a deposição apenas na retirada do substrato da subfase, resultando em filmes do tipo Z, e os valores de TR começam a cair após a deposição de aproximadamente vinte e uma camadas. Como foi observada a formação de agregados, a olho nu, sobre a superfície da subfase nas misturas contendo $84 \%$ de polímero em solução, não efetuamos a transferência dessa monocamada. Todos os filmes LB apresentaram coloração azulada, indicando que o polímero estava desdopado (base esmeraldina), o que foi confirmado com as medidas de UV-vis. A desdopagem das monocamadas mistas de polianilina com CdSt deve-se, principalmente, ao valor de $\mathrm{pH}$ (próximo de seis) da subfase.

É importante observar se a diferença nas características das monocamadas contendo diferentes porcentagens de 16-mero são refletidas no processo de transferência. Para comparar os resultados todos os filmes LB foram fabricados mantendo-se $\Pi$ constante $(29 \mathrm{mN} / \mathrm{m})$ durante o processo de transferência, exceto nos casos contendo $75 \%$ de 16-mero, no qual utilizamos $\Pi$ igual a $20 \mathrm{mN} / \mathrm{m}$, e $90 \%$ de oligômero, para o qual não foi realizada a deposição. As monocamadas contendo até $50 \%$ de 16-mero são facilmente transferidas tanto na subida quanto na descida do substrato, formando filmes LB tipo $\mathrm{Y}$, com valores de TR próximos à unidade. Entretanto, nos filmes mistos contendo de $60 \%$ a $75 \%$ de 16 -mero as deposições são favorecidas na subida do substrato, com valores de TR próximos a um, enquanto nas 
descidas os valores de TR são menores (entre 0.4 e 0.6), indicando uma transferência tipo Y, mas com caráter tipo Z. Novamente os filmes LB apresentaram coloração azulada, indicando o estado não dopado do polímero.

\section{4) Caracterização espectroscópica dos filmes $L B$}

\subsection{1) UV-vis}

Um espectro de absorção típico de filmes LB mistos logo após a deposição é mostrado nas Figuras 16 e 17. A Figura 16 ilustra o espectro de absorção de um filme LB misto de PANi com CdSt, exibindo uma forte absorção em torno de $590 \mathrm{~nm}$ (curva 16a), sendo muito similar ao espectro apresentado pelo filme LB misto de 16mero na Fig. 17a, ou seja, ambos materiais estão na forma de base esmeraldina, ainda que tenhamos usado CSA para processá-los. O estado desdopado da PANi tem sido relacionado à presença dessa banda de absorção na região de $600 \mathrm{~nm}$, atribuída a uma absorção de éxcitons devido à transferência de carga dos anéis benzênicos para o anel quinóide, juntamente com uma absorção próxima a $320 \mathrm{~nm}$ devido às transições $\pi-\pi^{*}$, características da presença de anéis conjugados. Espectros similares aos apresentados nas Fig. 16 e Fig. 17 foram observados para todos os filmes LB mistos, independentemente da quantidade utilizada de polímero ou oligômero. As soluções preparadas possuem coloração verde e têm um máximo de absorção em torno de $800 \mathrm{~nm}$, ou seja, nesta etapa de preparação os materiais estão dopados. A absorção em $800 \mathrm{~nm}$ tem sido atribuída a deslocalização de portadores (elétrons) nas cadeias poliméricas, devido à formação de uma banda polarônica. A protonação do polímero faz com que haja mudanças conformacionais, causadas pela torção dos anéis aromáticos, que resultam em alterações na extensão das conjugações $\pi$ ao longo das cadeias poliméricas, tendo como resultado o aparecimento da banda polarônica. A desdopagem ocorre quando estes são espalhamos sobre a superfície da água [29]. É possível que moléculas de CSA tenham se dissolvido no volume da subfase $(\mathrm{pH} \sim 6)$ utilizada. Entretanto, estes filmes LB mistos podem ser dopados novamente com vapor de $\mathrm{HCl}$. As características espectrais dos filmes dopados com vapor de $\mathrm{HCl}$ são muito semelhantes (curvas 16b e 17b). Após dopagem com $\mathrm{HCl}$, tanto em vapor quanto em solução, os filmes apresentam coloração esverdeada, 
exibindo características de absorção em 420 nm, e também um aumento na absorção na região de comprimentos de onda maiores (Fig. 16b).

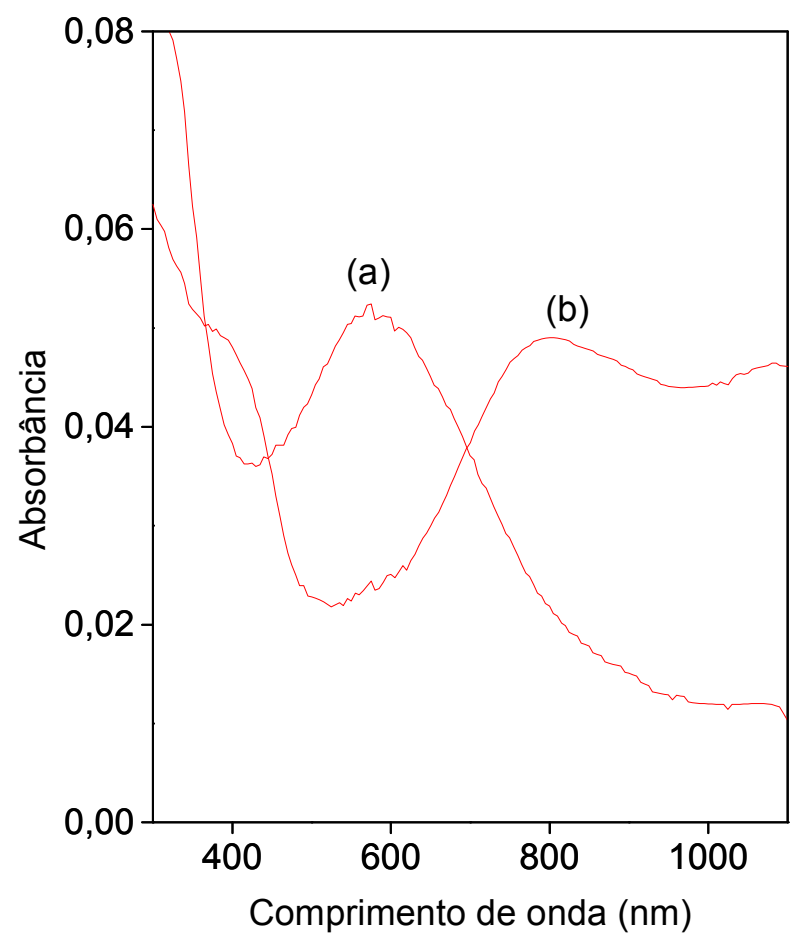

FIGURA 16- Espectro UV-vis de uma monocamada mista de PANi e estearato de cádmio: a) logo após a deposição; b) dopado em vapor de HCl por dez minutos.

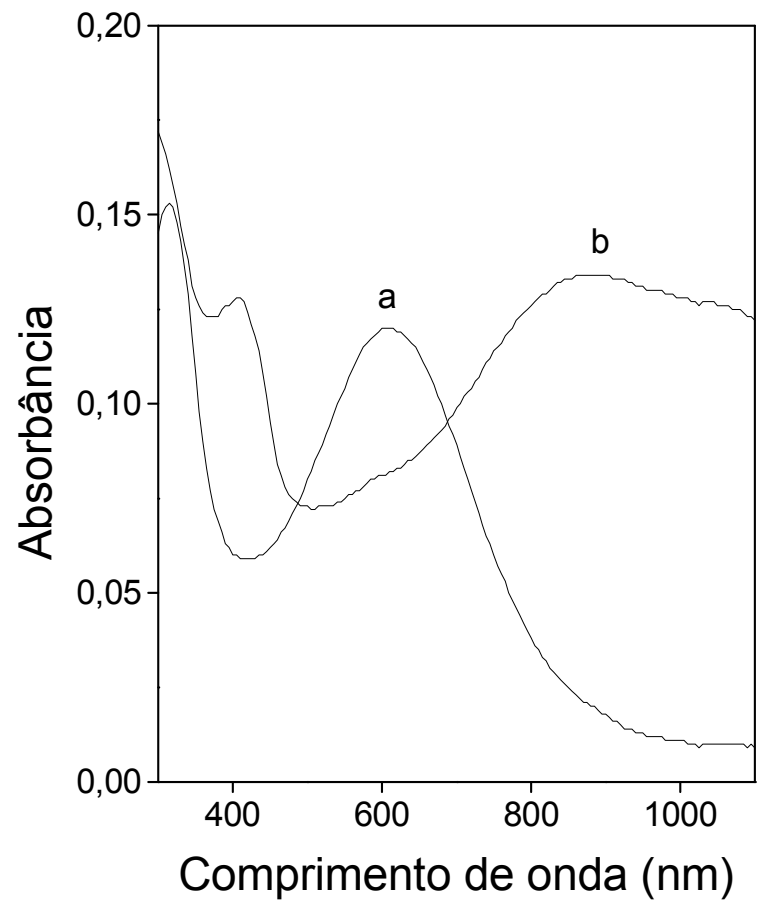

FIGURA 17 - Espectro UV-vis de uma monocamada mista de 16-mero e estearato de cádmio: a) logo após a deposição; b) dopado em vapor de $\mathrm{HCl}$ por dez minutos. 
A dependência linear da absorbância em $590 \mathrm{~nm}$ com o aumento do número de camadas depositadas, como mostrado nas Figuras 18 e 19, indica que a polianilina e o 16-mero são depositados uniformemente com o estearato de cádmio. Observamos também que a absorbância de um número similar de camadas aumenta linearmente com o aumento da concentração de polianilina e 16-mero na solução. A absorbância para um dado número de camadas depositadas é menor num filme com $75 \%$ de oligômero em massa na solução do que num filme contendo apenas $50 \%$, como notado na Figura 20. Tal fato é atribuído à transferência irregular dos filmes cuja solução continha 75\% de 16-mero em massa, devido à menor estabilidade das monocamadas neste caso.

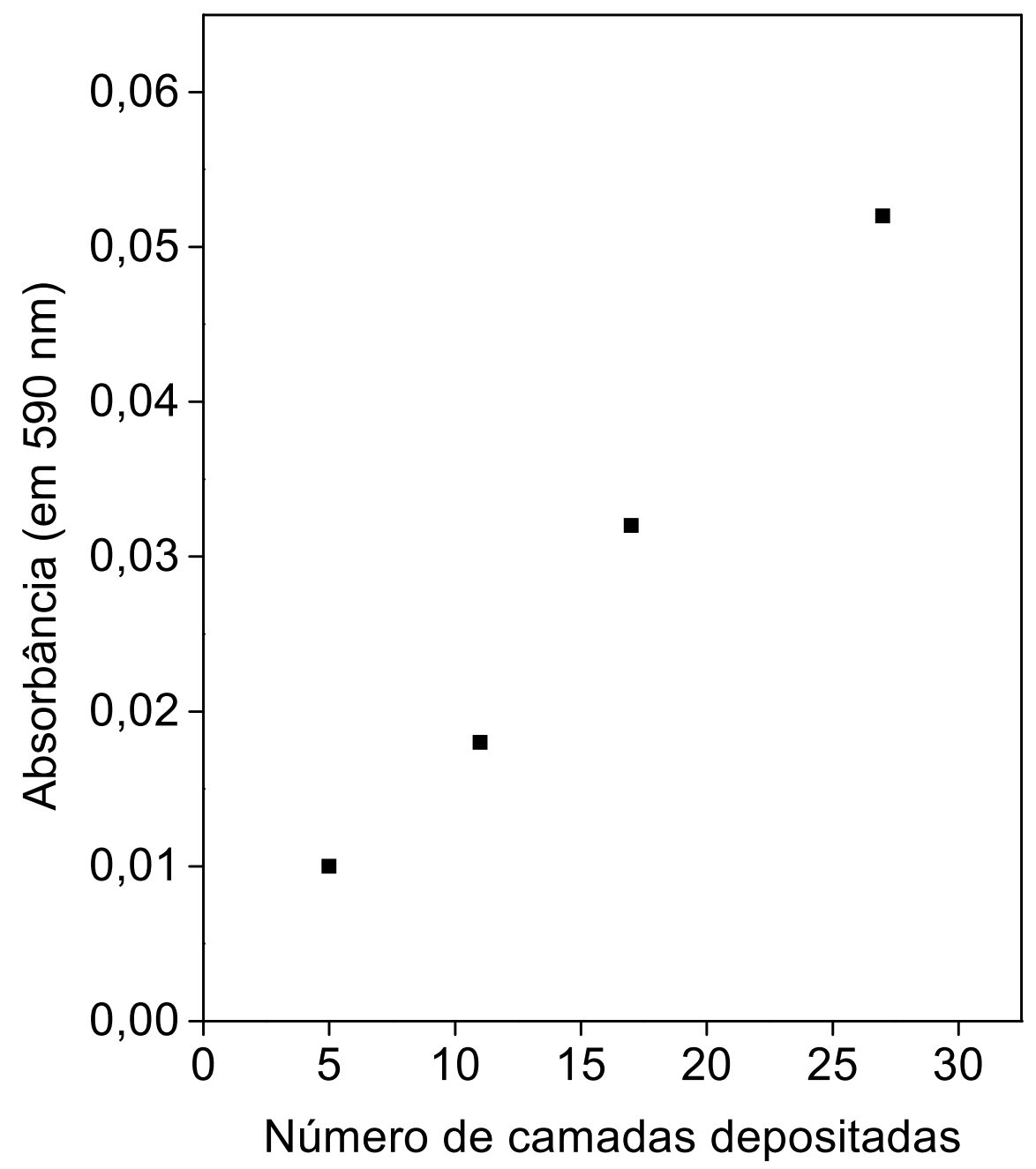

FIGURA 18 - Variação da absorbância em função do número de camadas depositadas, em $590 \mathrm{~nm}$, para filmes mistos de PANi e estearato de cádmio. 


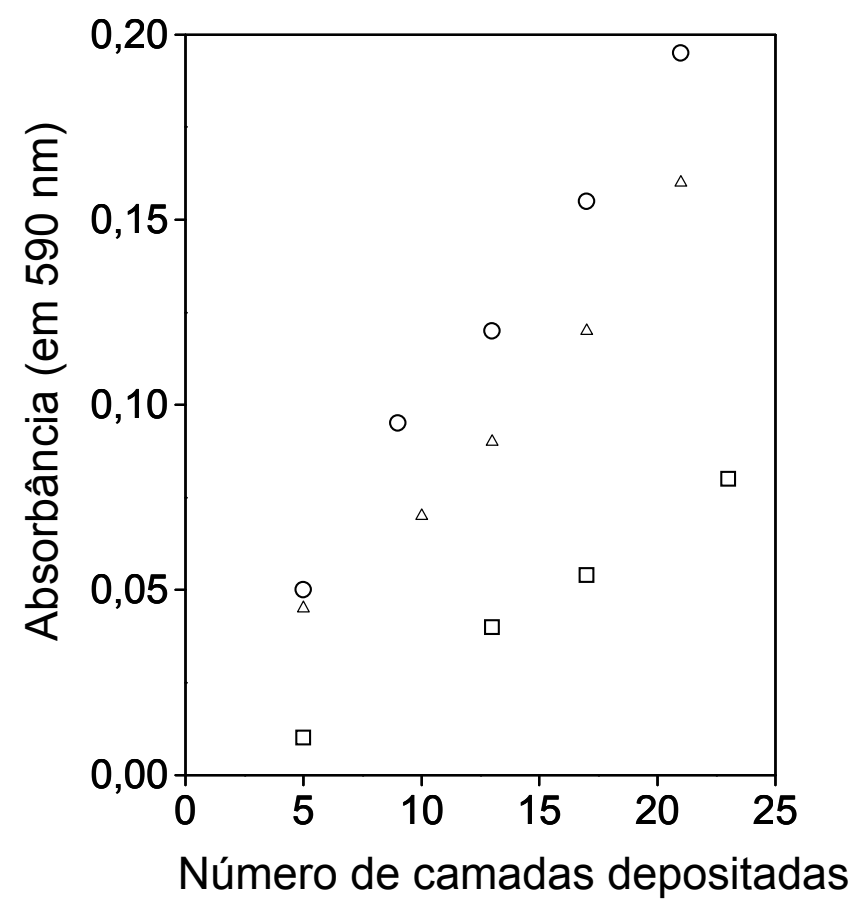

FIGURA 19 - Variação da absorbância em função do número de camadas depositadas, em $590 \mathrm{~nm}$, para filmes mistos de16-mero e estearato de cádmio em diferentes percentagens de 16mero em massa na solução: ( ) 25\%; (O) 50\%; (U) $75 \%$.

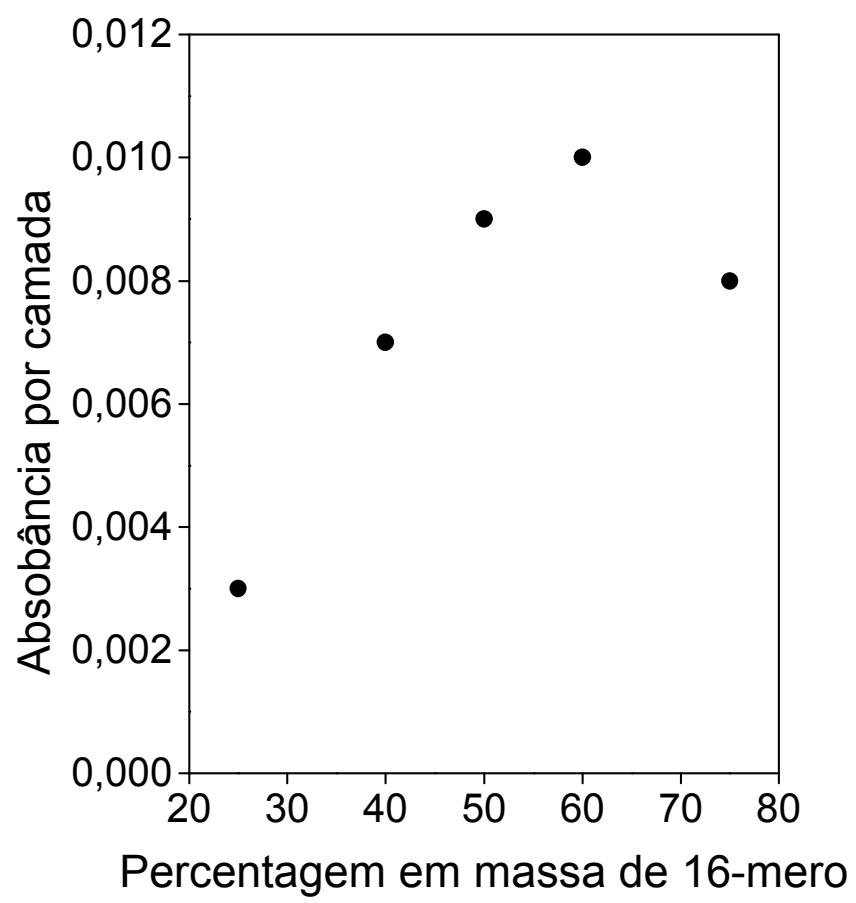

FIGURA 20 - Variação da absorbância por camada depositada em função da percentagem utilizada de 16-mero na solução. 


\subsection{2) FTIR}

As Figuras 21 e 22 mostram os espectros de transmitância dos filmes LB mistos, contendo 21 camadas depositadas. A Figura 21 ilustra o espectro de transmitância de um filme LB misto de polianilina com estearato de cádmio. A transferência das moléculas de 16-mero foi também verificada pelos resultados de FTIR, como ilustra a Fig. 22, na qual são mostrados três espectros para diferentes composições de 16-mero e CdSt na solução inicial que deu origem às monocamadas. A transmitância observada na Fig. 22 é relativa, uma vez que as três curvas foram colocadas juntas apenas para efeito de comparação.

A forte absorção em $1548 \mathrm{~cm}^{-1}$ (correspondendo às vibrações do grupo carboxilato, $\mathrm{COO}^{-}$) e a ausência de qualquer absorção em $1700 \mathrm{~cm}^{-1}$ indicam apenas a presença de estearato de cádmio, e não uma mistura de sal de estearato e ácido esteárico nos filmes LB [27]. Fortes picos de absorção em 2918 e $2849 \mathrm{~cm}^{-1}$, correspondentes ao estiramento simétrico e anti-simétrico, respectivamente, do grupo $\mathrm{CH}_{2}$, e um pico fraco em $1468 \mathrm{~cm}^{-1}$ (vibrações angulares do $\mathrm{CH}_{2}$ ), confirmam a presença de CdSt nos filmes LB [27]. Além das absorções características do estearato de cádmio, picos de absorção correspondentes à polianilina na base esmeraldina foram encontrados em 1516 (estiramento das ligações $\mathrm{C}=\mathrm{C}$ dos anéis quinóides), 1328 (estiramento das ligações C-N de anéis benzênicos e quinóides), 1156 (combinações de vibrações axiais e angulares da estrutura quinóide) e $806 \mathrm{~cm}^{-1}$ (vibração angular fora do plano das ligações N-H presentes na estrutura da molécula de PANi) [27,36,65]. Pode ser notado na Figura 22 que os picos de absorção do 16mero estão localizados entre aqueles correspondentes ao CdSt na região de 1600 a $1500 \mathrm{~cm}^{-1}$. Entretanto, com o aumento da quantidade de 16-mero os picos de absorção correspondentes podem ser vistos claramente (curvas $22 b$ e 22c), localizados em 1587 (estiramento das ligações $\mathrm{C}=\mathrm{C}$ dos anéis quinóides), 1503 (estiramento das ligações $\mathrm{C}=\mathrm{C}$ dos anéis benzênicos), 1320 (vibrações axiais e angulares das ligações C-N da base esmeraldina), e $1159 \mathrm{~cm}^{-1}$ (combinações de vibrações axiais e angulares da estrutura quinóide) [27,65], em comparação com aqueles do estearato de cádmio, localizados em 1548 e $1468 \mathrm{~cm}^{-1}$, claramente observados quando a quantidade de 16-mero é diminuída (curva 22a). A ausência de inclinação do espectro na região de 2000 a $4000 \mathrm{~cm}^{-1}$ indica que os oligômeros não 
estão dopados [27], corroborando os resultados de UV-vis. Verifica-se, portanto, a transferência de PANi e 16-mero com estearato de cádmio nos filmes LB, como já evidenciado nos resultados de UV-vis.

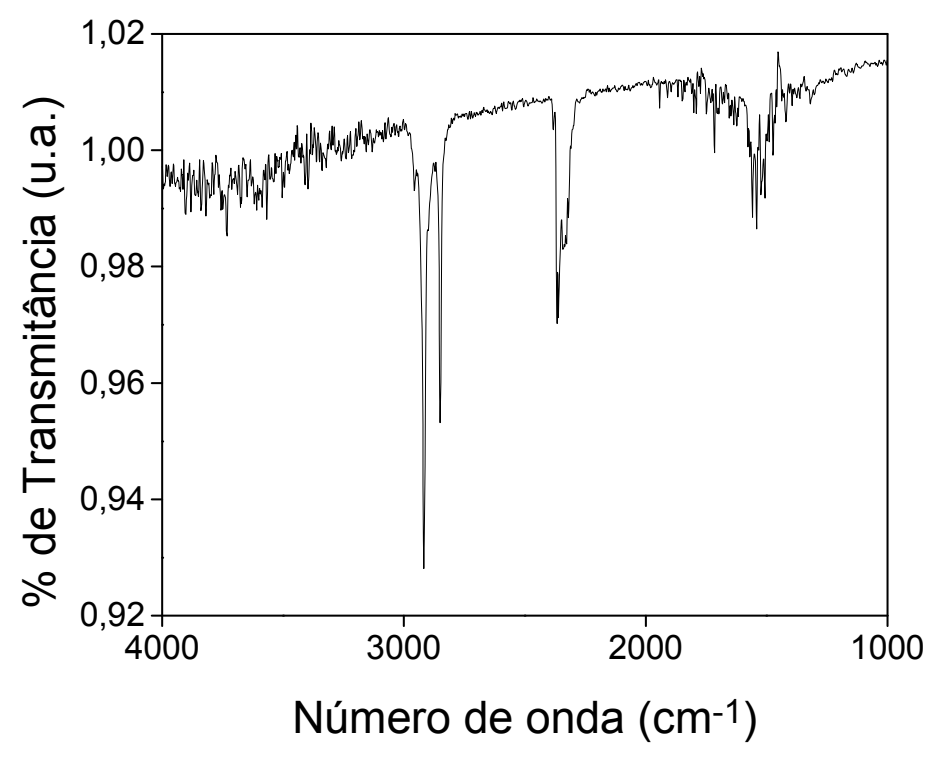

FIGURA 21 - Espectro de transmitância de FTIR de filme LB misto de PANi (55\% de polímero em massa na solução) e estearato de cádmio.

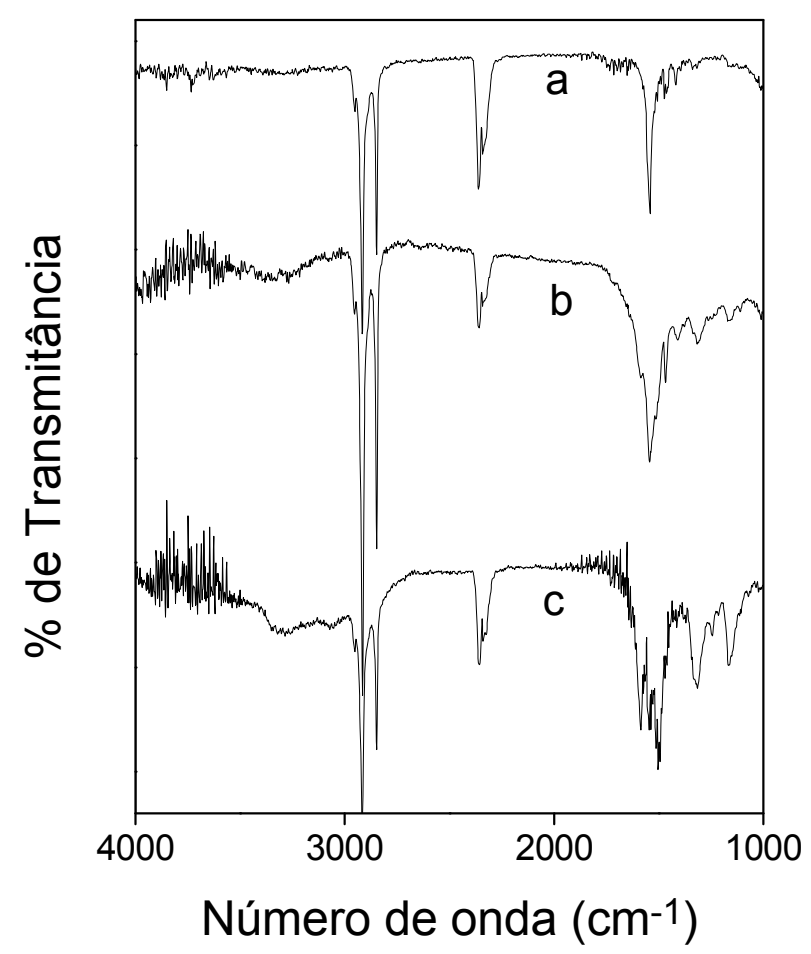

FIGURA 22 - Espectro de FTIR de filmes LB mistos (21 camadas) contendo diferentes percentagens de 16-mero e estearato de cádmio: a) 25\%; b) 50\% e c) 75\% de 16-mero na solução de espalhamento. 


\section{5) Caracterização estrutural dos filmes $\mathrm{LB}$}

Os resultados de difração de raios-X são usados para inferir sobre o ordenamento estrutural nos filmes LB. É possível que as moléculas possam adotar diferentes formas estáveis de empacotamento durante ou imediatamente após o processo de transferência dos filmes para a superfície dos substratos [66]. Outro fator que pode interferir na estrutura dos filmes LB é a formação de domínios nas monocamadas. Medidas realizadas por microscopia no ângulo de Brewster, imediatamente após o espalhamento dos filmes de Langmuir, confirmaram a formação de diferentes domínios nas monocamadas mistas de PANi [67] e 16-mero com CdSt. O problema em questão relaciona-se em como a formação de tais domínios é refletida na fabricação dos filmes LB.

Os filmes LB mistos correspondentes a baixas percentagens (em massa) de PANi e 16-mero em solução exibiram um conjunto de picos de difração intensos, com uma distância entre bicamadas correspondente a $49.7 \AA$ (30\% em massa de PANi na solução, curva b na Fig.24), e 49,8 Å para os filmes de 16-mero (25\% em massa na solução, curva a na Fig. 25). Esses valores estão muito próximos da distância normalmente citada na literatura para filmes LB de estearato de cádmio ( $\sim 50 \AA$ ) [64]. Isso indica que estas moléculas possam estar presentes como domínios separados nos filmes LB mistos, como esquematizado na Figura 23 abaixo.

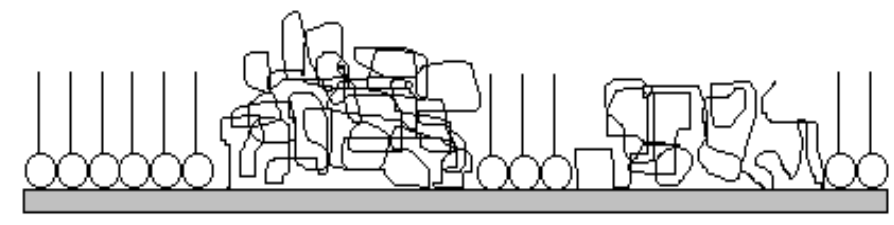

FIGURA 23 - Representação esquemática dos domínios de polianilina (ou 16-mero) com estearato de cádmio nos filmes $L B$.

Entretanto, em comparação com o filme LB de estearato de cádmio puro (Figura 24a), as intensidades absolutas dos picos de difração dos filmes mistos são menores e esses são mais largos. Para o filme LB correspondente a 75\% de 16-mero em massa na solução, em particular, nenhum pico de difração pode ser observado claramente, como ocorre no filme misto de PANi correspondente a uma elevada percentagem de polímero adicionada em solução (Fig 24e). Com o aumento da quantidade de polímero nos filmes mistos (curvas c e d na Fig.24), ainda que a distância entre bicamadas não tenha sido alterada significativamente $(50,3 \pm 0,4 \AA)$, há 
uma diminuição na intensidade dos picos de difração, fato esse relacionado com a diminuição da quantidade de estearato de cádmio nos filmes de Langmuir.

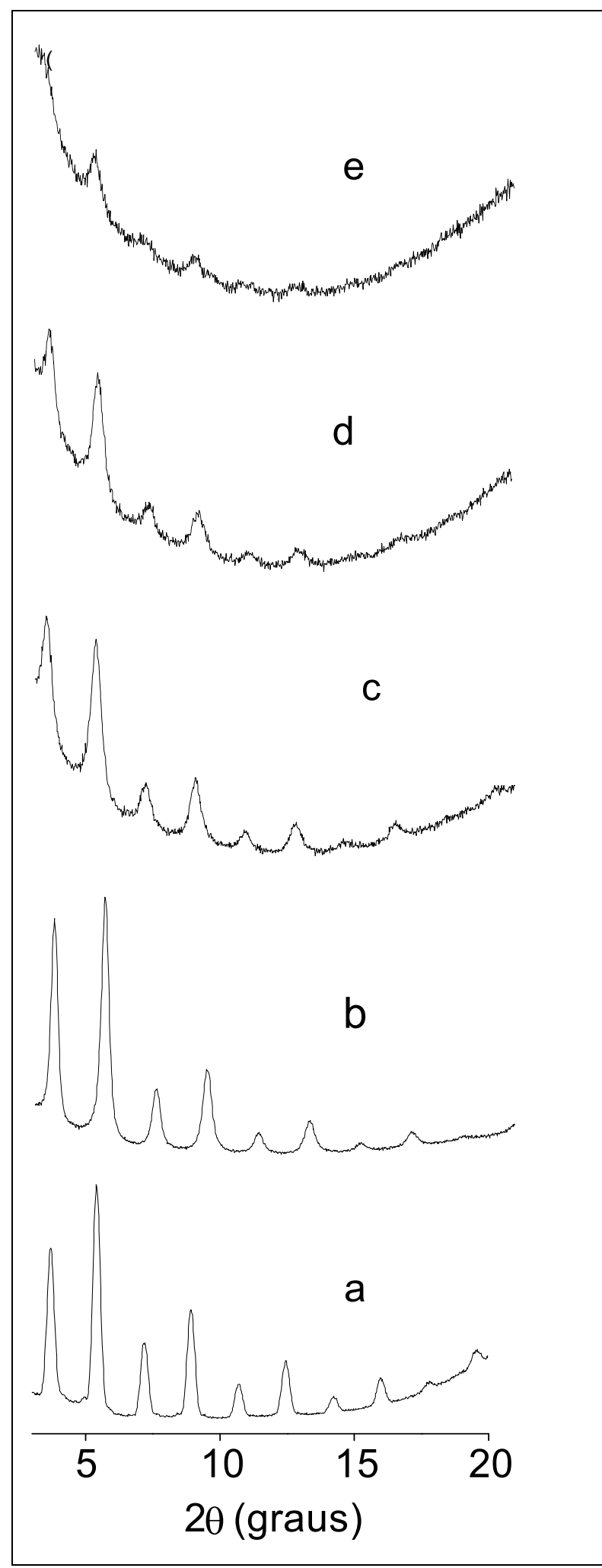

FIGURA 24 - Espectro de difração de raios- $X$ em filmes $L B$ mistos de PANI com estearato de cádmio.

a) estearato de cádmio puro;

b) $30 \%$ de PANi;

c) $43 \%$ de $P A N i$;

d) $55 \%$ de $P A N i$;

e) $66 \%$ de PANi 


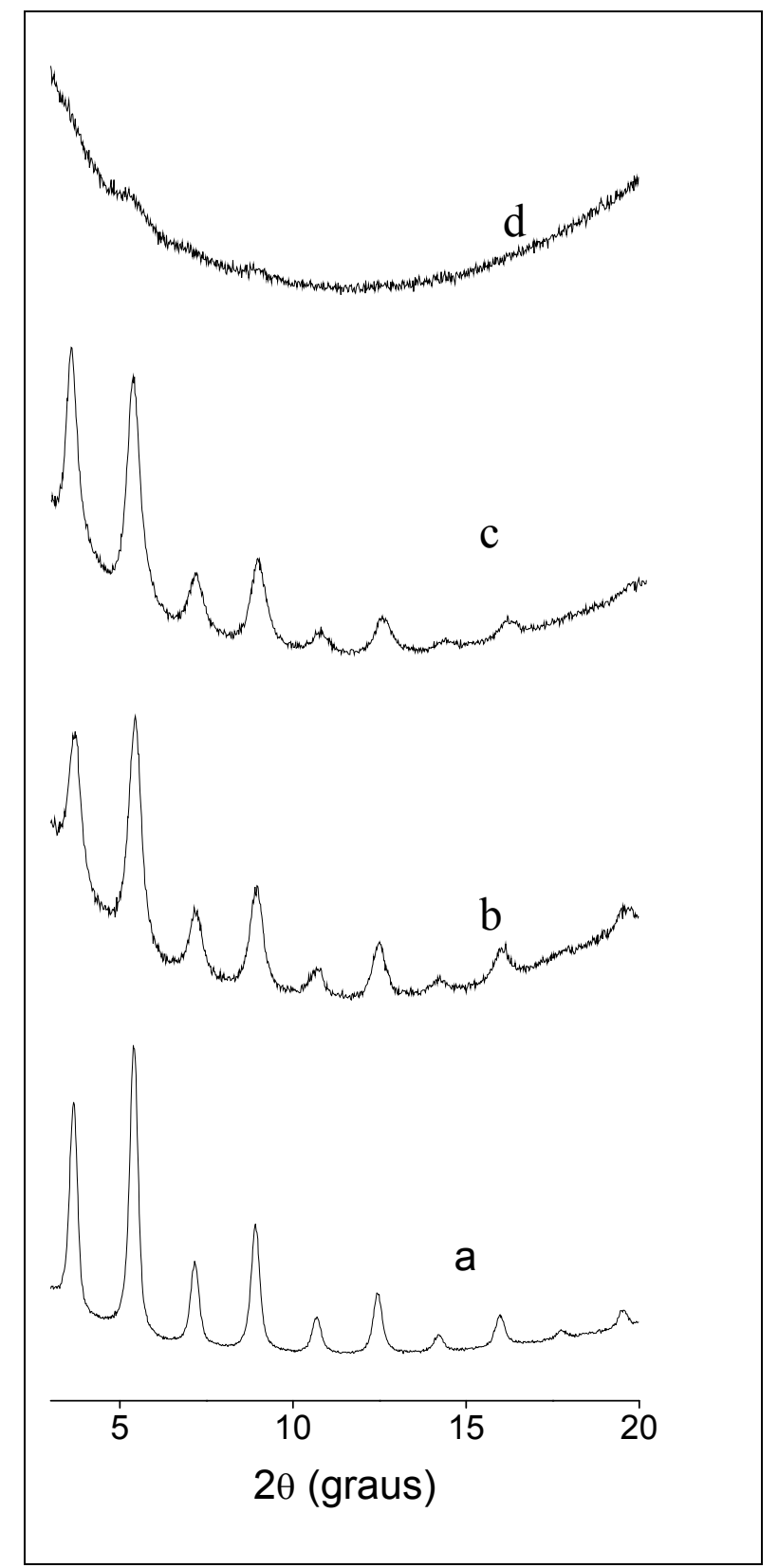

FIGURA 25 - Espectros de difração de raios-X de filmes LB (21 camadas) contendo diferentes percentagens, em massa, de 16-mero e CdSt: (a) 25\%; (b) 50\%; (c) 64\% e (d) 75\% de 16-mero.

É interessante notar que no caso de 66\% de PANi em solução (curva 24e), os picos de difração correspondem a uma distância entre bicamadas de $(51,3 \pm 0,5 \AA)$, indicando que possivelmente a PANi possa estar presente no mesmo plano dos domínios de estearato de cádmio. Portanto, o aumento da quantidade de polímero nas soluções sugere que algumas moléculas de PANi possam estar empilhadas nos 
planos polares dos domínios de estearato de cádmio, como esquematizado na Figura 26 abaixo:

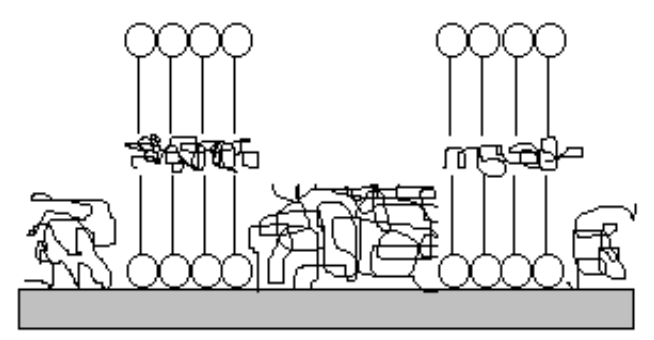

FIGURA 26 - Representação esquemática dos domínios de polianilina com estearato de cádmio nos filmes LB quando elevadas percentagens de polímero são adicionadas em solução.

Como mencionado anteriormente, as monocamadas compostas contendo $66 \%$ de PANi e 75\% de 16-mero exibiram uma estabilidade menor que a dos outros filmes mistos e ainda foi observado um decréscimo nos valores de área molecular média, mantendo-se a monocamada comprimida em um valor fixo de pressão de superfície. A pouca estabilidade dos filmes de Langmuir nesses casos pode estar sendo refletida no empacotamento dos domínios de PANi e estearato de cádmio, que de alguma forma relaciona-se à "expulsão" de algumas moléculas de polianilina e 16-mero da matriz de estearato de cádmio (observar Fig. 26) nos filmes LB, confirmando os resultados de difração de raios-X.

Os resultados das Figuras 24 e 25 dão informação apenas sobre os domínios de estearato de cádmio e de como esses domínios são afetados pela presença do polímero ou oligômero. Nenhuma conclusão pôde ser tirada a respeito da estrutura dos domínios de 16-mero, nem se o filme LB analisado é um sistema verdadeiro de multicamadas. Para o filme LB contendo $75 \%$ de 16 -mero em massa na solução, em particular, nenhum pico de difração pode ser observado claramente, como ocorre nos filmes mistos com elevada percentagem de PANi. A evidência da formação de um sistema estruturado camada por camada foi comprovada pela análise dos resultados de UV-vis. A absorção do oligômero e da polianilina cresce linearmente com o número de camadas depositadas, e verificou-se também que tal absorção aumenta quando a quantidade de PANi e 16-mero era aumentada até um certo limite. Evidências posteriores de uma estrutura formada camada por camada vieram dos resultados elipsométricos, que permitiram obter a espessura dos filmes. 
Com respeito à composição dos filmes LB, as distâncias observadas entre bicamadas indicam uma estrutura tipo Y em todos os tipos de filmes LB estudados, ainda que diferentes tipos de deposição tenham sido observados durante a fabricação dos mesmos. É possível que o filme transferido tipo $\mathrm{Z}$ possa ter sofrido um rearranjo para uma estrutura mais estável tipo Y, durante ou após o processo de deposição. Esse comportamento já foi observado em outros tipos de filmes mistos [66].

A concavidade observada nas Figuras 24 e 25 está associada à interferência do substrato no espectro total de difração, resultado que já foi verificado experimentalmente por A. Dhanabalan ${ }^{1}$.

Os resultados de estabilidade dos filmes de Langmuir (Fig. 8), aumento da absorção (Fig. 20), que deixa de ser linear a partir de uma determinada percentagem de 16-mero, e os espectros de difração de raios-X (Figuras 24 e 25), indicam a possibilidade de haver uma transição de fase. Se experimentos forem realizados com valores intermediários de percentagens de 16 -mero, entre $60 \%$ e $75 \%$, seria possível determinar o tipo de transição ( $1^{\mathrm{a}}$ ou $2^{\underline{a}}$ ordem), o ponto de transição, e ainda explicar os resultados à luz de modelos de transição de fase.

\section{6) Potencial de superficie e microscopia óptica dos filmes $\mathrm{LB}$}

As medidas de potencial de superfície em filmes $\mathrm{LB}\left(\Delta \mathrm{V}_{\mathrm{LB}}\right)$ são geralmente usadas para verificar a uniformidade dos filmes. Nesse tipo de medida os filmes de Langmuir são transferidos sobre substratos de vidro metalizados, sendo utilizado ouro em nossas medidas. Foram depositados diferentes números de camadas com a finalidade de verificar o efeito de espessura na uniformidade dos filmes LB.

Para os filmes contendo de $30 \%$ a $55 \%$ de PANi em solução, os valores de potencial de superfície ficaram no intervalo de 240 a $250 \mathrm{mV}$, independentemente da espessura do filme depositado. O potencial medido dos filmes LB mistos de 16-mero está na faixa de 250 a $300 \mathrm{mV}$, sendo também independente do número de camadas depositadas e da composição do filme LB misto.

São mostrados nas Tabelas 4 e 5 os resultados nos filmes LB mistos de PANi e 16-mero, e os valores obtidos nas monocamadas na interface ar/água, apenas para efeito de comparação.

\footnotetext{
${ }^{1}$ A. Dhanabalan, resultados não publicados
} 
TABELA 4 - Valores de potencial de superfície para filmes LB mistos contendo diferentes quantidades de PANi e estearato de cádmio.

\begin{tabular}{c|ccc}
$\begin{array}{c}\text { \% em massa } \\
\text { de PANi }\end{array}$ & Número de camadas & $\Delta \mathbf{V}_{\mathbf{L B}}(\mathbf{m V})$ & $\mathbf{V}_{\mathbf{m}}(\mathbf{m V})$ \\
\cline { 2 - 4 } & & & \\
\hline \multirow{3}{*}{43} & 03 & 260 & 250 \\
& 07 & 260 & \\
& 13 & 280 & \\
\hline \multirow{2}{*}{55} & 03 & 210 & 200 \\
& 07 & 240 & \\
& 27 & 250 & \\
& & &
\end{tabular}

TABELA 5 - Valores de potencial de superfície para filmes LB mistos contendo diferentes quantidades de 16-mero e estearato de cádmio.

\begin{tabular}{|c|c|c|c|}
\hline $\begin{array}{l}\% \text { em massa } \\
\text { de } 16 \text {-mero }\end{array}$ & Número de camadas & $\Delta \mathrm{V}_{\mathrm{LB}}(\mathrm{mV})$ & $\mathbf{V}_{m}(\mathbf{m V})$ \\
\hline \multirow[t]{3}{*}{25} & 03 & 250 & 170 \\
\hline & 07 & 270 & \\
\hline & 03 & 270 & 200 \\
\hline \multirow[t]{2}{*}{50} & 07 & 280 & \\
\hline & 27 & 280 & \\
\hline \multirow[t]{3}{*}{60} & 03 & 250 & \\
\hline & 19 & 260 & \\
\hline & 03 & 280 & 230 \\
\hline \multirow[t]{2}{*}{75} & 07 & 300 & \\
\hline & 27 & 310 & \\
\hline
\end{tabular}

Nos filmes LB mistos o potencial de superfície $\left(\Delta \mathrm{V}_{\mathrm{LB}}\right)$ aumenta ligeiramente com o número de camadas depositadas e praticamente atinge um valor constante após um certo número delas, um comportamento já notado antes em outros tipos de filmes LB [68]. É de se mencionar que no caso do 16-mero o potencial de superfície dos filmes LB é ligeiramente maior, em torno de $70 \mathrm{mV}$ de diferença, que o potencial medido para a monocamada correspondente. Nos filmes mistos de PANi essa diferença é menor (em torno de 30 a $50 \mathrm{mV}$ ). Em muitos dados na literatura [69] o potencial de superfície dos filmes LB é menor que o potencial da monocamada, principalmente devido a dois fatores: i) contribuição negativa proveniente da interface filme/substrato, provavelmente devido à injeção de cargas do metal (ouro) utilizado para metalização do substrato, e ii) a monocamada não estar ionizada, 
inexistindo a contribuição, geralmente negativa, da dupla camada $\left(\Psi_{0}\right)$ formada na interface ar/água. Entretanto, as monocamadas mistas em estudo possuem ácido esteárico completamente ionizado, cuja contribuição para o potencial, devido à $\Psi_{0}$, é altamente negativa. Para ilustrar esse ponto deve-se lembrar que uma monocamada de ácido esteárico não ionizado tem um potencial de superfície em torno de $400 \mathrm{mV}$ [56], enquanto as monocamadas completamente ionizadas investigadas aqui (ácido esteárico sobre a água contendo íons metálicos em uma subfase com $\mathrm{pH} \cong$ seis) possuem um potencial de superfície em torno de $130 \mathrm{mV}$. Quando as monocamadas são transferidas para substratos sólidos a alta contribuição negativa proveniente da dupla camada formada na interface filme/água é perdida ou minimizada, o que possivelmente explica os valores mostrados nas Tabelas 4 e 5 .

A não observação de qualquer estrutura distinta nos filmes, por meio de microscopia óptica, indica que os filmes fabricados são muito uniformes. Isso ocorreu para todas as diferentes percentagens de PANi e 16-mero utilizadas. A diferença de $10 \mathrm{mV}$ nas medidas de potencial de superfície nos filmes LB mistos está próxima do limite de precisão do equipamento, indicando a excelente uniformidade dos filmes LB mistos fabricados. As medidas de potencial de superfície confirmam os resultados de microscopia, pois o potencial não varia quando diferentes partes do filme são analisadas.

\section{7) Condutividade elétrica (van der Pauw)}

Realizamos medidas preliminares de condutividade elétrica nos filmes mistos contendo $43 \%$ de PANi em solução utilizando o método de van der Pauw. As amostras, quando não dopadas, apresentaram valores de condutividade da ordem de $10^{-5}{\mathrm{~S} . \mathrm{cm}^{-1}}^{-1}$ Após a dopagem com vapor de $\mathrm{HCl}$ os valores de condutividade ficaram em torno de $10^{-4} \mathrm{~S}_{\mathrm{cm}} \mathrm{cm}^{-1}$. Não foi notada nenhuma variação significativa nos valores de condutividade elétrica desses filmes no intervalo de um mês, sendo que os mesmos ficaram expostos ao meio ambiente. Os valores de condutividade dos filmes mistos de polianilina com estearato de cádmio são três ordens de grandeza inferiores aos encontrados na literatura [16,26-35,36,38,42-47]. A baixa condutividade pode estar relacionada à presença de uma matriz isolante, e a uma possível orientação das 
cadeias poliméricas em que os anéis aromáticos ficam fora do plano das cadeias, em um filme muito condensado.

Nos filmes LB mistos de 16-mero a condutividade elétrica d.c. tanto ao longo

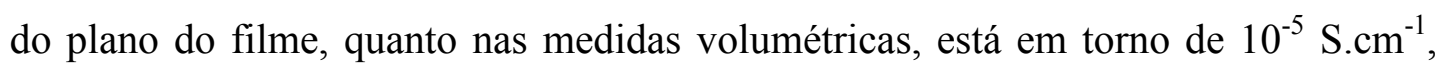
independentemente da composição do filme LB e do número de camadas depositadas. Esse valor está muito próximo dos valores encontrados para os filmes LB mistos de PANi com CdSt [54]. A condutividade no plano das amostras de 16mero aumentou para $10^{-4} \mathrm{~S}_{\mathrm{cm}}{ }^{-1}$ quando os filmes LB foram expostos ao vapor de $\mathrm{HCl}$.

\section{8) Elipsometria}

A elipsometria é um método óptico, não destrutivo, através do qual mede-se a mudança de polarização da luz durante a sua reflexão na interface filme/substrato. Com esta medida pode-se obter o índice de refração do filme (n), bem como sua espessura (d) e seu coeficiente de extinção $(\mathrm{k})$. As medidas requerem a caracterização óptica da superfície do substrato, e, em seguida uma nova caracterização da superfície coberta com o filme LB [70]. Os parâmetros elipsométricos medidos são os ângulos $\Delta \mathrm{e} \Psi$, os quais estão relacionados às constantes ópticas dos meios envolvidos (ar, filme, substrato) [70]. Uma fonte de luz (xenônio) incide um feixe que é polarizado e dirigido em direção à amostra que está depositada sobre uma lâmina de vidro metalizada (com ouro ou alumínio). Através de tratamentos matemáticos adequados (em um software especialmente desenvolvido pela Rudolph) propõem-se valores esperados para o índice de refração, o coeficiente de extinção e a espessura a ser medida, com base nas propriedades do material a ser analisado. O que o software faz é criar um conjunto de pontos que se ajustem aos valores experimentais, com um erro da ordem de $10^{-4}$ na aproximação realizada pelo programa. Se o valor proposto para determinar a espessura do filme for próximo do valor real, o método matemático de aproximação converge, caso contrário diverge. É de se mencionar que, assumindo-se a correta calibração e operação do equipamento, as quantidades medidas $\Delta$ e $\Psi$ são exatas, sendo afetadas apenas pela rugosidade e cristalinidade da amostra. Se os valores atribuídos à espessura e ao índice de refração são corretos dependerá se o modelo matemático escolhido para a análise é adequado ao tipo de filme. Para a polianilina utilizou-se como parâmetro 
inicial um valor de $\mathrm{n}$ usualmente atribuído aos polímeros $(\cong 1,5)$ e um valor de $\mathrm{k}$ pequeno $(\cong 0,01)[71]$.

A Figura 27 ilustra os resultados de elipsometria para um filme LB de polianilina pura, contendo nove camadas, obtido em subfase ácida $(\mathrm{pH} \sim 2)$.

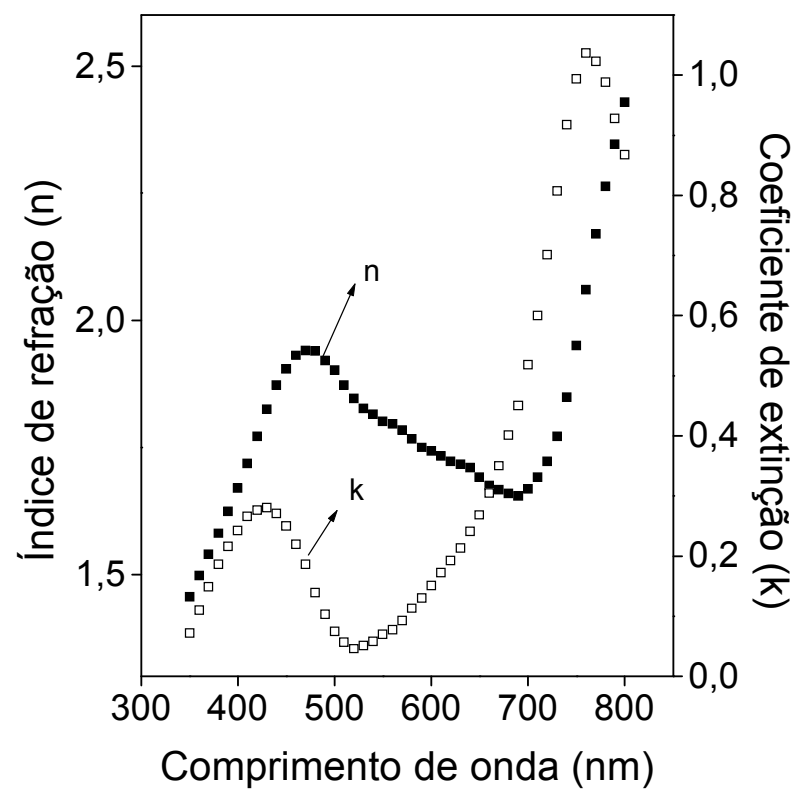

FIGURA 27 - Variação do índice de refração (n) e coeficiente de extinção ( $k$ ), obtidos por elipsometria, em um filme $L B$ de polianilina pura, contendo 9 camadas, utilizando subfase ácida $(\mathrm{pH} \sim 2)$.

Como pode ser observado há um intervalo onde n varia menos, entre 450 e 700 nm. As variações nos valores de n, principalmente nas regiões de fortes absorções (420 e $780 \mathrm{~nm}$ ), podem estar relacionadas ao efeito de dispersão anômala [72,73], no qual há uma alteração de fase da radiação eletromagnética incidente, causada pelo espalhamento da luz ao atravessar um meio dielétrico. Como conseqüência imediata há uma descontinuidade na curva de dispersão do material na região da banda de absorção. Podemos ainda notar que na região condutora ( $\lambda$ próximo a $760 \mathrm{~nm}$ ) a polianilina possui um coeficiente de extinção muito próximo ao de um material condutor (igual à unidade no caso dos metais). Outra relação interessante que pode ser verificada é que a variação de k com o comprimento de onda é semelhante ao espectro de absorção por espectroscopia de UV-vis. Esse resultado era esperado, uma vez que a absorção óptica ( $\left.\alpha^{\prime}\right)$ e o coeficiente de extinção estão relacionados através da expressão:

$\alpha^{\prime}=\frac{4 \cdot \pi \cdot k}{\lambda}$ 
onde $\lambda$ é o comprimento de onda, e $\mathrm{k}$ o coeficiente de extinção. O método de aproximação forneceu um valor de $20 \AA$ por camada para os filmes LB em estudo, sendo muito similares aos obtidos em filmes de PANi por eletrodeposição [71,74,75]. Os valores apresentados de espessura e índice de refração na região de 500 a 700 nm parecem ser razoáveis.

Como será uma constante nos resultados a serem apresentados, muitas vezes o valor de $\mathrm{n}$ difere daquele esperado para um polímero $(\sim 1,5)$. Entretanto, em muitos desses resultados a espessura obtida por camada está dentro do esperado, consistente com a estrutura de multicamadas evidenciada nos resultados de UV-vis. Feita essa ressalva, decidimos apresentar os resultados obtidos em filmes mistos de PANi e 16mero, até para poder suscitar a discussão sobre o uso da elipsometria para análise de filmes LB. Em geral, a técnica espectroscópica para um larga faixa de comprimentos de onda é raramente utilizada na literatura. A maioria dos resultados é obtida para um valor de comprimento de onda específico, simplificando o tratamento matemático dos dados de $\Psi$ e $\Delta$ para gerar valores de n, k e espessura da amostra. Adota-se, geralmente, um valor de $\mathrm{n}$ fixo, próximo ao obtido em amostras volumétricas, para determinação dos valores de k e da espessura. Esta última grandeza é o que usualmente se deseja saber. Para os filmes mistos de polianilina e 16-mero com estearato de cádmio os dados foram analisados na região de 500 a $700 \mathrm{~nm}$. Utilizou-se essa faixa do espectro porque para valores de comprimento de onda menores que $400 \mathrm{~nm}$, e maiores que $700 \mathrm{~nm}$, havia grandes descontinuidades nos espectros devido aos ajustes matemáticos utilizados para determinação dos valores de $\mathrm{n}$ e k. Portanto, os problemas de modelagem relatados aqui, com $\mathrm{n}$ assumindo valores aparentemente fisicamente injustificáveis, à luz do conhecimento atual, não aparecem com freqüência na literatura.

Admitindo, então, que as variações de n sejam possíveis, encontramos algumas explicações, como descrito a seguir.

As Tabelas 6 e 7 mostram os valores de espessura por camada em filmes mistos de polianilina e 16-mero. Os filmes mistos correspondentes a $43 \%$ em massa de PANi adicionada na solução, na sua forma reduzida (desdopados), apresentam valores de $\mathrm{n}$ próximos de 1,3, independentemente do número de camadas depositadas, e k variando no intervalo de 0,03 a 0,05. Para comprimentos de onda maiores que $600 \mathrm{~nm}$ há uma tendência na diminuição dos valores de $\mathrm{n}$ e $\mathrm{k}$ com o 
aumento da espessura do filme LB, um comportamento já observado em outro tipo de filme de polianilina [74]. Essa variação nos valores de $\mathrm{n}$ e $\mathrm{k}$ tem sido interpretada como a formação de zonas vazias (espaços preenchidos por ar) nos filmes LB [76]. A espessura por camada variou de 22 a 44 A nos três casos analisados.

TABELA 6 - Resultados elipsométricos (constantes ópticas e espessura por camada) de filmes LB contendo diferentes percentagens de PANi e CdSt.

\begin{tabular}{|c|c|c|c|}
\hline $\begin{array}{c}\text { \% em massa } \\
\text { de PANi }\end{array}$ & $\begin{array}{l}\text { Número de camadas } \\
\text { depositadas }\end{array}$ & $\begin{array}{c}\text { Parâmetros } \\
\text { elipsométricos } \\
(\lambda=\mathbf{5 0 0 - 7 0 0 ~ n m )}\end{array}$ & $\begin{array}{c}\text { Espessura por camada } \\
(\AA ̊)\end{array}$ \\
\hline $43 \%$ & 3 & $\begin{array}{c}\mathrm{n}=1,3 \\
\mathrm{k}=0,05\end{array}$ & 27 \\
\hline $55 \%$ & 3 & $\begin{array}{c}\mathrm{n}=1,3 \\
\mathrm{k}=0.08\end{array}$ & 30 \\
\hline $43 \%$ & 7 & $\begin{array}{c}\mathrm{n}=1,4 \\
\mathrm{k}=0,04\end{array}$ & 22 \\
\hline $55 \%$ & 7 & $\begin{array}{c}\mathrm{n}=1,3 \\
\mathrm{k}=0,09\end{array}$ & 34 \\
\hline $43 \%$ & 13 & $\begin{array}{c}\mathrm{n}=1.3 \\
\mathrm{k}=0,03\end{array}$ & 44 \\
\hline $55 \%$ & 27 & $\begin{array}{l}\mathrm{n}=1,4 \\
\mathrm{~K}=0,2\end{array}$ & 32 \\
\hline
\end{tabular}

Nos filmes correspondendo a 55\% em massa de PAni na solução observa-se que os valores encontrados para $\mathrm{n}$ são inferiores aos encontrados na literatura $(\sim 1,5)$ [71,74]. Em filmes com 3 e 7 camadas o índice de refração está em torno de 1,3, e, em filmes mais espessos (27 camadas) $\mathrm{n}$ está próximo de 1,4. Os valores de $\mathrm{k}$ para os filmes mais finos ( 3 e 7 camadas) estão em torno de 0,08 , sendo próximos dos valores citados na literatura [74], mas no caso do filme com 27 camadas o valor encontrado é alto $(\sim 0,2)$. Nessa percentagem utilizada de PANi na solução há uma tendência de acréscimo nos valores de $\mathrm{n}$ e $\mathrm{k}$ com o aumento da espessura dos filmes LB, contrariamente ao que se observa no caso anterior (filmes LB correspondentes a $43 \%$ em massa de PANi na solução). A tendência de aumento no valor de $\mathrm{n}$ indica a formação de um filme mais denso, enquanto o aumento no valor de $\mathrm{k}$ pode ser atribuído a um aumento na deslocalização eletrônica ao longo das cadeias, devido a um aumento 
no número de sítios oxidados [71,74], ou seja, possivelmente há uma percentagem maior de PANi no filme LB.

TABELA 7 - Resultados elipsométricos (constantes ópticas e espessura por camada) de filmes LB contendo diferentes percentagens de 16-mero e CdSt.

\begin{tabular}{|c|c|c|c|}
\hline $\begin{array}{l}\text { \% em massa } \\
\text { de } 16 \text {-mero }\end{array}$ & $\begin{array}{c}\text { Número de camadas } \\
\text { depositadas }\end{array}$ & $\begin{array}{c}\text { Parâmetros } \\
\text { elipsométricos } \\
(\lambda=500-700 \mathrm{~nm})\end{array}$ & $\begin{array}{c}\text { Espessura por camada } \\
(\AA)\end{array}$ \\
\hline 25 & 3 & $\begin{array}{c}1,5<\mathrm{n}<1,7 \\
\mathrm{k} \cong 0,02\end{array}$ & 28 \\
\hline 50 & 3 & $\begin{array}{l}1,3<\mathrm{n}<1,4 \\
0,1<\mathrm{k}<0,2\end{array}$ & 25 \\
\hline 75 & 3 & $\begin{array}{c}\mathrm{n} \cong 1,1 \\
\mathrm{k} \cong 0,04\end{array}$ & 27 \\
\hline 25 & 7 & $\begin{array}{c}\mathrm{n}=1,3 \\
0,06<\mathrm{k}<0,081\end{array}$ & 24 \\
\hline 50 & 7 & $\begin{array}{l}1,4<\mathrm{n}<1,6 \\
0,1<\mathrm{k}<0,2\end{array}$ & 25 \\
\hline 75 & 7 & $\begin{array}{c}\mathrm{n}=1,1 \\
\mathrm{k}=0,04\end{array}$ & 27 \\
\hline 50 & 27 & $\begin{array}{l}1,3<\mathrm{n}<1,4 \\
0,1<\mathrm{k}<0,2\end{array}$ & 24 \\
\hline 75 & 27 & $\begin{array}{c}1,2<\mathrm{n}<1,3 \\
0,09<\mathrm{k}<0,17\end{array}$ & 24 \\
\hline
\end{tabular}

Nota-se na Tabela 7 que para um pequeno número de camadas depositadas ( 7 camadas) a espessura por camada tem um pequeno acréscimo com o aumento da quantidade de 16-mero nos filmes mistos. Para um filme LB contendo 50\% de 16 mero a espessura por camada é muito próxima do valor obtido através dos resultados de difração de raios-X. Tal fato indica que a espessura por camada é essencialmente determinada pelos domínios de estearato de cádmio, que são empacotados perpendicularmente ao substrato. Daí, as moléculas de 16-mero podem estar distribuídas entre esses domínios no interior de cada camada depositada. Quando a quantidade de 16-mero é aumentada esse efeito sobre a composição do filme LB torna-se mais aparente, como mostrado pela ausência de picos nos resultados de difração de raios-X para um filme misto correspondendo a 75\% de 16-mero em 
solução. É interessante notar que a espessura por camada é menor para filmes mais espessos (27 camadas) do que para aqueles mais finos (03 camadas), independentemente da composição entre 16-mero e CdSt. Para comprimentos de onda na região de 500 a $700 \mathrm{~nm}$, e para um polímero tal como a polianilina no seu estado reduzido, a literatura apresenta valores para o índice de refração que poderiam estar em torno de 1,4 a 1,6, enquanto o coeficiente de extinção é menor que 0,05 [74]. Para o estado de oxidação esmeraldina da polianilina estes valores são $\mathrm{n}=1,1$ a 1,3 e k $=0,1$ a 0,14 [74]. Verifica-se que independentemente do número de camadas depositadas, e da percentagem de 16-mero utilizada na solução, há uma tendência de diminuição nos valores de $\mathrm{n}$ para comprimentos de onda maiores, o que, novamente, pode estar relacionado com o aumento da porosidade nesse tipo de filme. Para os filmes contendo 27 camadas, os valores de $\mathrm{n}$ e k são indicativos de uma absorção maior pelo material devido a uma estrutura mais compacta nos filmes LB.

Se forem comparados os filmes mistos de PANi e 16-mero com apenas três camadas verifica-se que os filmes de 16-mero apresentam valores para o índice de refração (aproximadamente 1,5) maiores que os apresentados pelos filmes mistos de polianilina ( $\mathrm{n} \sim 1,3)$. $\mathrm{O}$ aumento nos valores do índice de refração indica a formação de filmes de 16-mero mais compactos que os de PANi, devido à facilidade de alinhamento das cadeias menores, embora tenha sido notada a presença de porosidade em ambos tipos de filme LB. Em relação aos valores de $\mathrm{k}$ a variação observada é bem menor, e os valores se aproximam $(\sim 0,05)$, o que pode ser um indicativo de que os filmes de PANi e 16-mero tenham a mesma atividade eletrônica nessa região de comprimentos de onda maiores que $500 \mathrm{~nm}$.

As possíveis discrepâncias nos valores encontrados nas tabelas acima podem ser atribuídas a diversos fatores, entre eles:

i) possíveis efeitos de anisotropia nas primeiras camadas dos filmes LB, que embora sejam relativamente fracos não são completamente insignificantes [25,77]. Steiger [25] relata que a diferença encontrada entre os valores calculados e experimentais em filmes LB de ácido araquídico aumenta quando a referência é feita entre a superfície coberta com ouro e o filme de multicamadas. Entretanto, se a referência utilizada for baseada nas quatro primeiras camadas e o filme $\mathrm{LB}$, os resultados obtidos são muito próximos dos calculados 
ii) diferenças nas propriedades ópticas de filmes finos quando comparados com filmes espessos [78]. A parte real (n) do índice de refração complexo é menor, enquanto a parte imaginária $(\mathrm{k})$ por sua vez é freqüentemente maior nos filmes finos. A razão disto está atribuída à estrutura desses filmes, como por exemplo a formação de espaços vazios que aumentam a porosidade, fato este observado nos resultados aqui analisados. Em um caso ideal a extinção da luz (k) pode ser considerada apenas como o resultado de absorção pelos átomos. Em filmes finos essa absorção pode ser influenciada por espalhamentos da superfície e imperfeições no volume, como o aumento de porosidade, que têm como conseqüência um aumento nos valores de $\mathrm{k}$ e uma diminuição nos valores de $n$.

\section{9) Conclusões}

A evidência de que a mesma quantidade de PANi e 16-mero foi transferida durante cada deposição foi obtida nos resultados de UV, que também mostraram que os materiais encontram-se no estado de oxidação de base esmeraldina, em sua forma desdopada. A desdopagem deve ter ocorrido devido ao valor de $\mathrm{pH}$ da subfase [29] (aproximadamente seis), uma vez que o polímero encontrava-se em seu estado dopado devido à presença de CSA na solução inicial.

A formação de um filme com multicamadas dos oligômeros de polianilina pode ser corroborada através dos resultados de elipsometria, sendo consistente com os resultados de UV-vis. A presença de PANi e 16-mero no estado não dopado foi confirmada pelos espectros de FTIR. Os resultados de XRD indicaram a presença de domínios separados de estearato de cádmio nos filmes LB, consistente com a separação de fase observada nas monocamadas, verificada através de resultados preliminares por microscopia no ângulo de Brewster. Os resultados elipsométricos indicaram que a espessura por camada é principalmente determinada pelos domínios de cádmio até $50 \%$ de oligômero (em peso) na composição dos filmes LB mistos, acima do qual a estrutura do filme LB é predominantemente determinada pela quantidade de 16-mero. 


\section{CAPÍTULO 4}

\section{4) Efeito do m-cresol na fabricação de filmes Langmuir-Blodgett (LB) de PANi}

\section{1) Introdução}

A utilização de ácidos funcionalizados [39-42] para o processamento da PANi facilitou a aplicação da técnica LB em polianilinas. Com isto evitaram-se as dificuldades de síntese na cuba, descartou-se o uso de derivados do polímero, uma vez que possuem propriedades elétricas inferiores ao do material puro, e eliminou-se a utilização de solventes como o NMP, que é fortemente solúvel em água, implicando na possibilidade de perda de material para a subfase líquida. Nesta linha de pesquisa de possíveis condições de processamento do polímero, o $m$-cresol tem merecido lugar de destaque uma vez que filmes LB de PANi tiveram a condutividade elétrica aumentada pela simples exposição ao vapor dessa substância [6]. Além deste detalhe, filmes obtidos por "casting" de polianilina processada com CSA e $m$-cresol tiveram, além do aumento na condutividade elétrica, uma melhora na cristalinidade [7,8,79]. Essas melhorias têm sido atribuídas a variações conformacionais nas cadeias poliméricas de uma forma mais compacta para uma mais estendida, no processo denominado de dopagem secundária [7-9]. É interessante notar que as propriedades adquiridas pelo material permanecem, mesmo após a remoção do dopante secundário ( $m$-cresol), o que pode ser considerado como um "efeito de memória" [80].

Nesta seção mostraremos as implicações do uso de $m$-cresol e CSA para a fabricação de filmes de Langmuir e LB de PANi. Os resultados foram obtidos em monocamadas e filmes LB com o polímero puro, e com filmes mistos de polianilina com estearato de cádmio. A experiência tem mostrado que sobre a subfase de água pura $(\mathrm{pH} \sim 5,6)$ não se consegue formar monocamadas estáveis de polianilina pura [5]. Tal fato não ocorre nas monocamadas mistas de PANi/CdSt, permitindo ainda a fabricação de filmes LB de melhor qualidade que aqueles utilizando-se subfases 
ácidas [54,55]. Desta forma foi possível investigar os efeitos do $m$-cresol em duas condições distintas de subfase.

\section{2) Parte Experimental}

As soluções para os experimentos foram preparadas da seguinte forma: i) uma mistura de polianilina com CSA (1:1,3 em peso) em $\mathrm{CHCl}_{3}$ foi ultrassonificada por uma hora e meia, sendo filtrada posteriormente; ii) $m$-cresol (10\% em volume) foi adicionado na solução acima, após filtrá-la. Soluções similares foram preparadas adicionando-se ácido esteárico com a finalidade de obter filmes mistos de PANi com estearato de cádmio. Com a polianilina pura como material espalhado sobre a subfase, a área molecular média foi calculada com base na massa molar da unidade repetitiva (monômero) da anilina $\left(91 \mathrm{~g} \cdot \mathrm{mol}^{-1}\right)$. Entretanto, no caso das monocamadas mistas, a área molecular média foi calculada como descrito na seção 2.1.2 do capítulo 2. Este procedimento fornece informações a respeito do efeito da adição de polianilina na monocamada de ácido esteárico. Filmes de Langmuir estáveis, do polímero puro, foram obtidos utilizando-se subfases ácidas $(\mathrm{pH} 2)$ [5]. Os filmes mistos foram espalhados sobre subfases contendo $\mathrm{CdCl}_{2}\left(4,0.10^{-4}\right.$ mol. $\left.\mathrm{L}^{-1}\right)$, nas quais o pH foi ajustado para 6 adicionando-se bicarbonato de sódio $\left(5,0.10^{-5} \mathrm{~mol} \cdot \mathrm{L}^{-1}\right)$. As monocamadas foram comprimidas a uma velocidade de 10 a $30 \mathrm{~mm} / \mathrm{min}$.

Para as monocamadas de polianilina pura sobre subfases ácidas, filmes LB do tipo $\mathrm{Z}$ são fabricados tanto na presença quanto na ausência de $m$-cresol. A única diferença é que aquelas obtidas na presença de $m$-cresol são obtidas em pressões de superfície menores (de 12 a $15 \mathrm{mN} / \mathrm{m}$ ), com valores de TR no intervalo de 0,6 a 0,8. Os filmes mistos podem ser transferidos com facilidade, levando a deposições do tipo Y, com valores de TR próximos a unidade em ambos os casos, na presença e na ausência de $m$-cresol.

Os espectros UV-vis foram obtidos em filmes LB de polianilina pura depositados sobre vidro. Para os filmes mistos utilizamos como substratos vidro da classe b270 e quartzo. Os filmes mistos foram transferidos a uma pressão de superfície de $29 \mathrm{mN} / \mathrm{m}$, mantida constante durante a fabricação dos filmes LB, enquanto os filmes de PANi pura foram transferidos a uma pressão de superfície no 
intervalo de 12 a $15 \mathrm{mN} / \mathrm{m}$ quando o $m$-cresol foi utilizado no processamento do polímero, e $18 \mathrm{mN} / \mathrm{m}$ na ausência de $m$-cresol para processar a PANi.

Os espectros de UV-vis foram obtidos num espectrofotômetro de feixe duplo, modelo 2001, da Hitachi. As medidas de difração de raios-X foram realizadas num difratômetro da Rigaku Rotaflex, modelo RU 200B, que utiliza um alvo de cobre. Os resultados de FTIR foram obtidos em um instrumento da BOMEN.

\section{3) Efeito do m-cresol na formação das monocamadas de polianilina}

O uso do $m$-cresol no processamento da PANi pode gerar dois efeitos: i) o aumento da solubilidade do polímero no solvente da mistura, uma vez que o $m$-cresol é um bom solvente para a polianilina, e ii) o possível efeito de dopagem secundária causado pela ação de ambos, o CSA e o $m$-cresol. Para evitar o primeiro efeito, o $m$ cresol foi adicionado apenas após a solução de PANi com $\mathrm{CSA}$ e $\mathrm{CHCl}_{3}$ ter sido filtrada, como descrito na seção 2.1. Nota-se que o espalhamento do polímero sobre a superfície da subfase é mais lento quando o $m$-cresol está presente, o que significa que o material como um todo ficou menos hidrofílico.

A Figura 28 mostra as curvas de pressão de superfície em função da área por molécula (П X A), sobre a superfície de subfases ácidas com ácido toluenossulfônico (TSA), quando o $m$-cresol está presente (curva b) e ausente (curva a) na solução que formará a monocamada. Embora não haja nenhuma variação significativa na natureza das curvas de pressão de superfície, há um aumento nos valores de área molecular quando o $m$-cresol é usado. Tal fato nos levou a investigar se esse agente plastificante é incorporado no filme Langmuir-Blodgett, apesar de ser solúvel em água. Os resultados de FTIR nos filmes LB mistos de PANi/CdSt indicam que não há nenhum traço de $m$-cresol nos filmes transferidos. Os espectros obtidos são similares ao apresentado para a PANi na seção 3.2 no capítulo 3. Para a análise não se tornar repetitiva, esses resultados de FTIR não serão reapresentados neste capítulo. Como esse solvente é parcialmente solúvel em água, então o aumento nos valores de área molecular pode estar associado a variações conformacionais na cadeia polimérica. Sabe-se que as moléculas de polianilina sofrem variações de uma conformação molecular mais enovelada para uma mais estendida quando o $m$-cresol é usado no processamento do polímero $[7,8,79,80]$. 


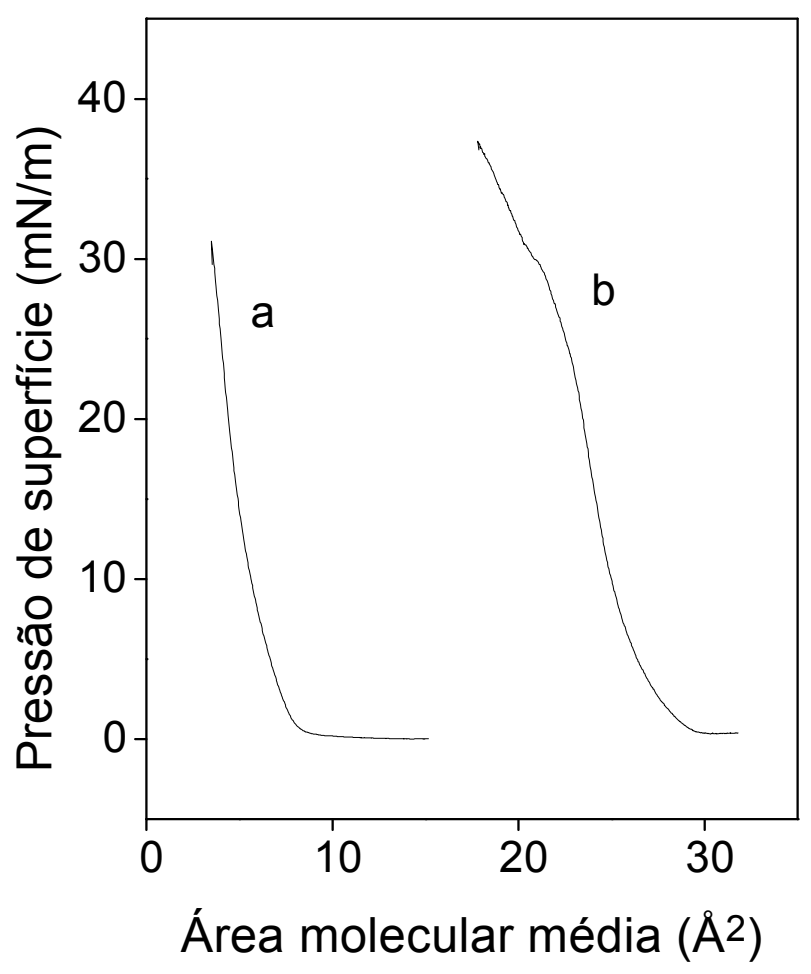

FIGURA 28 - Curvas (ПX A) de monocamadas de PANi processada com CSA na ausência (a) e na presença (b) de m-cresol na solução inicial, em subfases ácidas.

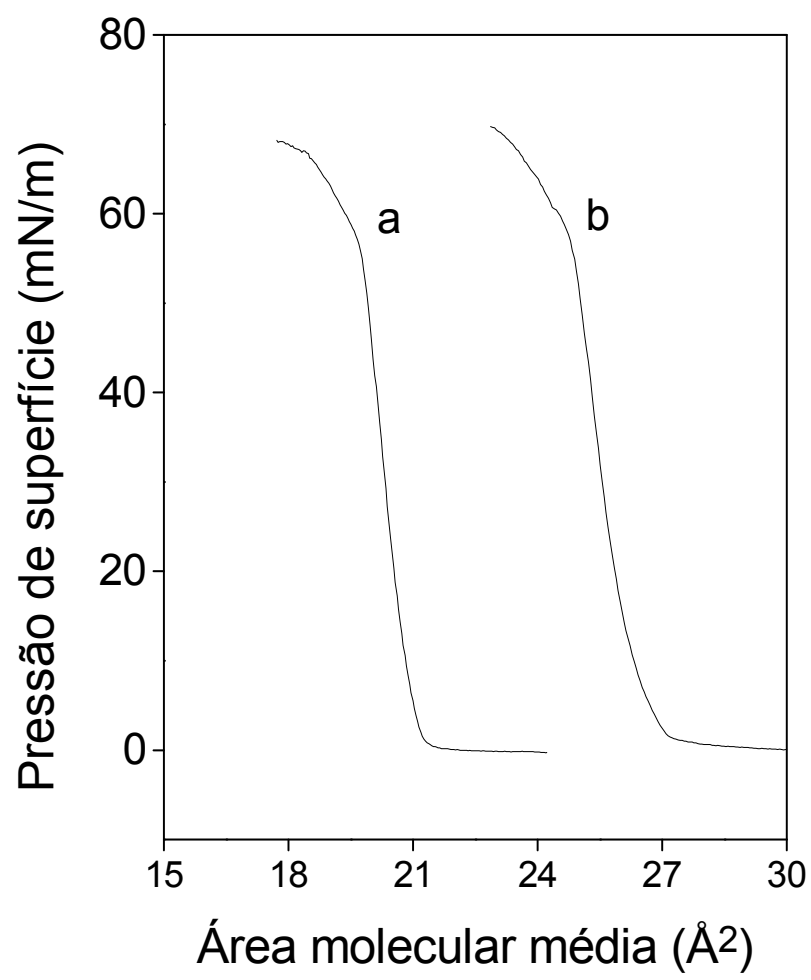

FIGURA 29 - Curvas (ПX A) de filmes LB mistos, contendo $50 \%$ em peso, de PANi/CdSt na ausência (a) e na presença (b) de m-cresol durante o processamento do polímero. 
Essa expansão nos valores de área é notada no caso dos filmes mistos também. Como pode ser observado na Figura 29, para uma monocamada formada de uma solução contendo 50\% (em massa) de PANi e CdSt, o uso de $m$-cresol também implica num aumento nos valores de área. Não foi notado nenhum tipo de dependência entre a pressão de colapso e as características dos filmes de Langmuir.

Os resultados de potencial de superfície também foram afetados pelo uso de $m$-cresol. Como pode ser observado na Figura 30, a utilização de $m$-cresol para processar o polímero implica em curvas mais expandidas, que ocupam valores de área maiores, e todas estão deslocadas para valores iniciais não nulos de potencial de superfície imediatamente após o espalhamento da solução.

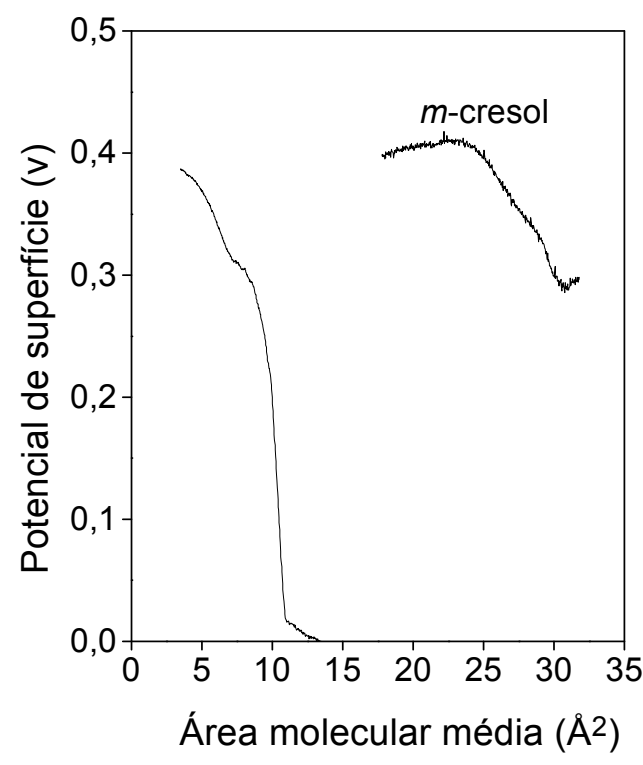

(a)

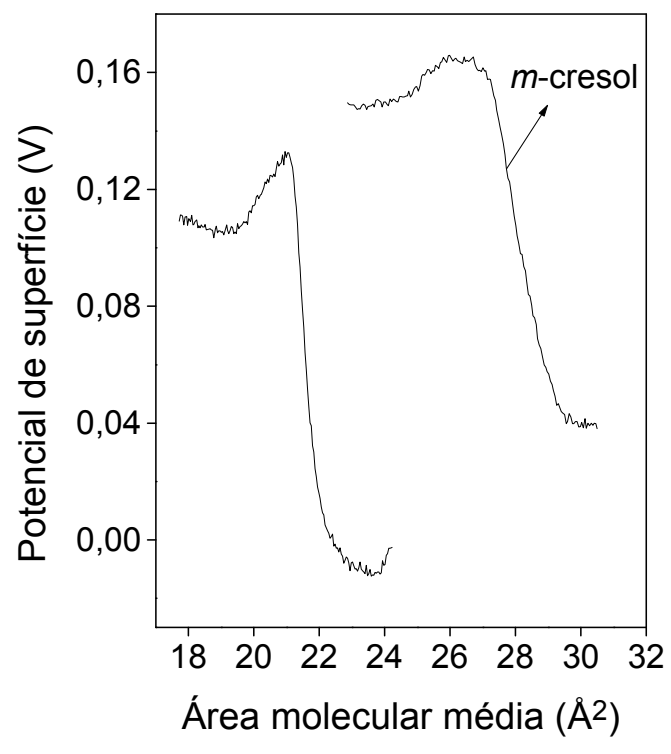

(b)

FIGURA 30 - Curvas de potencial de superficie para monocamadas de polianilina: (a) pura, formadas sobre subfases ácidas $(\mathrm{pH}=2$, TSA) e (b) filmes mistos de PANi com estearato de cádmio.

$\mathrm{O}$ valor máximo alcançado pelo potencial de superfície $\left(\mathrm{V}_{\mathrm{m}}\right)$ nas monocamadas foi também relativamente maior na presença de $m$-cresol, como mostrado na Tabela 8. Alguns valores dessa tabela, no caso de subfases ácidas, foram obtidos da seção 2.2, do capítulo 2. Não é nossa intenção analisar o potencial de superfície quantitativamente, principalmente devido ao fato de não se poder atribuir valores às contribuições dipolares de macromoléculas, como a polianilina estudada aqui. Todavia, alguma informação pode ser retirada para um estudo comparativo. 
TABELA 8 - Valores máximos atingidos pelo potencial de superfície em filmes LB mistos, contendo $50 \%$ em massa, de PANi e estearato de cádmio, na ausência e na presença de $\mathrm{m}$-cresol em diferentes condições de subfase.

\begin{tabular}{c|cc}
$\begin{array}{c}\text { pH da subfase } \\
\text { tipo das monocamadas }\end{array}$ & $\begin{array}{c}\mathbf{V}_{\mathbf{m}}(\mathbf{m V}) \\
\text { sem } \boldsymbol{m} \text {-cresol }\end{array}$ & $\begin{array}{c}\mathbf{V}_{\mathbf{m}}(\mathbf{m V}) \\
\mathbf{c o m} \boldsymbol{m} \text {-cresol }\end{array}$ \\
\cline { 2 - 3 } $\mathrm{pH}=2$ & & \\
$\mathrm{PANi}$ pura & $\cong 350$ & $\cong 400$ \\
$\mathrm{pH}=6$ & & \\
$\mathrm{PANi} / \mathrm{CdSt}$ & $\cong 140$ & $\cong 170$ \\
\end{tabular}

Os resultados das monocamadas de polianilina pura são consideravelmente maiores porque os filmes foram formados sobre subfases ácidas. Em baixos valores de $\mathrm{pH}$ as moléculas de polianilina estão completamente dopadas e por isso há uma grande contribuição positiva da dupla camada, formada na interface filme/subfase, para o potencial de superfície [71]. Para as monocamadas mistas de PANi/CdSt formadas sobre subfases com valores de $\mathrm{pH}$ maiores $(\sim 6)$, essa contribuição da dupla camada elétrica é perdida porque o polímero não se encontra mais completamente protonado. Em ambos os casos, para a PANi pura e para os filmes mistos, o potencial de superfície observado é maior quando o $m$-cresol é usado. Isto pode estar relacionado com as mudanças conformacionais que as moléculas do polímero sofrem com a utilização deste agente plastificante.

\section{4) Caracterização dos filmes $L B$}

\subsection{1) UV-vis}

Com a utilização de subfases ácidas $(\mathrm{pH}=2)$ os filmes LB fabricados encontram-se parcialmente dopados, como indicado pela banda de absorção em torno de $760 \mathrm{~nm}$ no espectro de UV-vis mostrado na Figura 31 (curva a). 


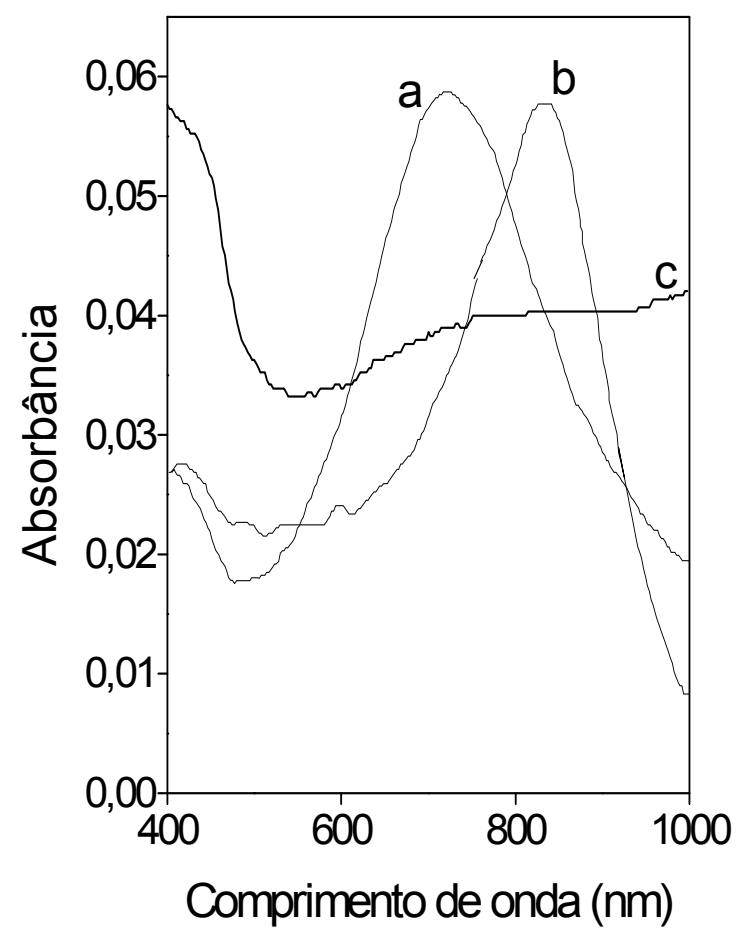

FIGURA 31 - Espectros de UV-vis dos filmes LB de PANi processada das seguintes formas:

(a) $\mathrm{PANi}+\mathrm{CSA}+\mathrm{CHCl}_{3}$;

(b) $\mathrm{PANi}+\mathrm{m}$-cresol $+\mathrm{CHCl}_{3}+\mathrm{CSA}$;

(c) $\mathrm{PANi}+\mathrm{CSA}+\mathrm{m}$-cresol $+\mathrm{CHCl}_{3}$

Um desvio no valor máximo de absorção de $760 \mathrm{~nm}$ (curva 30a) para $820 \mathrm{~nm}$ (curva 31 b) foi observado devido à presença de $m$-cresol durante o processamento da polianilina com a subsequente adição de CSA. Este resultado possivelmente indica que o $m$-cresol atua como dopante primário para a PANi, e a posterior adição de CSA não é sentida pelas cadeias poliméricas. Processando a polianilina com CSA em $m$-cresol, sob agitação constante, adicionando-se posteriormente clorofórmio $\left(\mathrm{CHCl}_{3}\right)$ após a dissolução completa do material, o espectro de UV-vis (curva 31c) exibe uma cauda de absorção característica do processo de dopagem secundária, devido à presença de polarons deslocalizados ao longo das cadeias [7,8]. Esses resultados confirmam que o efeito de dopagem secundária depende de um bom acoplamento entre o dopante primário (CSA) e secundário ( $m$-cresol) com a polianilina [7,8,82,83]. Entretanto, este efeito não foi suficientemente forte nos filmes LB para provocar variações drásticas nas medidas de condutividade elétrica (van der Pauw), características do processo de dopagem secundária relatado na literatura para filmes convencionais $[7,8,79]$. 
No caso dos filmes LB mistos este efeito não é tão significativo quando comparado àquele dos filmes LB de polianilina pura, e apenas um pequeno deslocamento de $570 \mathrm{~nm}$ a $590 \mathrm{~nm}$ foi observado na presença de $m$-cresol, como mostrado na Figura 32.

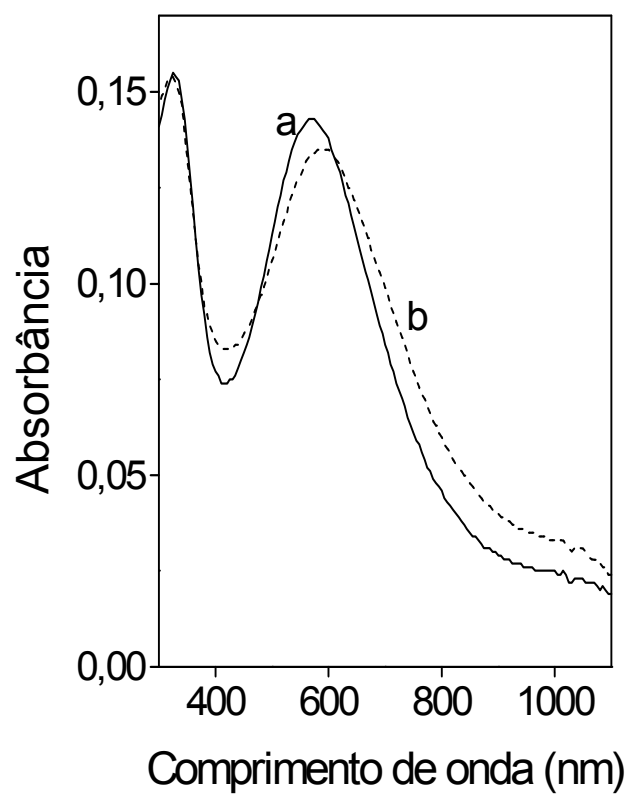

FIGURA 32 - Espectros de UV-vis de filmes LB mistos contendo 50\% em massa de PANi e CdSt. (a) PANi processada na ausência de m-cresol, e (b) PANi processada na presença de mcresol.

Desta forma, o efeito do $m$-cresol parece ser dependente do estado de dopagem do filme de Langmuir, e é consideravelmente mais forte quando a monocamada já está dopada. Como mencionado anteriormente, os espectros de FTIR analisados revelam que os filmes LB mistos de PANi não contêm qualquer traço remanescente de CSA e $m$-cresol [54].

\subsection{2) Condutividade elétrica (van der Pauw)}

As medidas de $\sigma$, utilizando o método de van der Pauw, indicaram que não há aumento significativo na condutividade devido ao acréscimo de $m$-cresol na solução utilizada para espalhar o material sobre a subfase líquida. Os valores de condutividade elétrica obtidos para os filmes mistos recém depositados estão em torno de $10^{-5} \mathrm{~S} . \mathrm{cm}^{-1}$. O efeito da exposição de filmes LB, produzidos em subfases ácidas, ao vapor de $m$-cresol serão comentados no capítulo 6. Após expor o filme LB ao vapor de $\mathrm{HCl}$ por 10 minutos a condutividade elétrica aumentou para $10^{-4} \mathrm{~S}_{\mathrm{cm}} \mathrm{cm}^{-1}$. 
No caso dos filmes LB de polianilina pura, que foram produzidos já no estado parcialmente dopado, os valores de condutividade elétrica variaram em torno de $10^{-5}$ S.cm ${ }^{-1}$ a $10^{-4} \mathrm{~S} . \mathrm{cm}^{-1}$, ambos na presença e na ausência de $m$-cresol. Ainda que o $m$ cresol afete o espectro de UV-vis dos filmes LB fabricados, ele não causa nenhum aumento significativo na condutividade elétrica. Isto pode ser justificado pelas interações polímero/polímero e polímero/contra-íons, no caso de subfases ácidas, que causam conformações moleculares distintas na interface ar/água. Acreditamos que conformações moleculares mais enoveladas das cadeias poliméricas continuam predominantes em ambos, nas monocamadas e nos filmes LB, apesar do uso de $m$ cresol para o processamento da polianilina. Observações similares de variações no espectro de UV-vis sem nenhum acréscimo na condutividade foram observadas anteriormente [6].

\subsection{3) Difração de raios-X}

Para confirmar se o $m$-cresol afeta o empacotamento molecular dos domínios de estearato de cádmio nos filmes LB mistos, foram obtidos espectros de difração de raios-X na ausência e na presença de $m$-cresol, como mostrado na Figura 33.

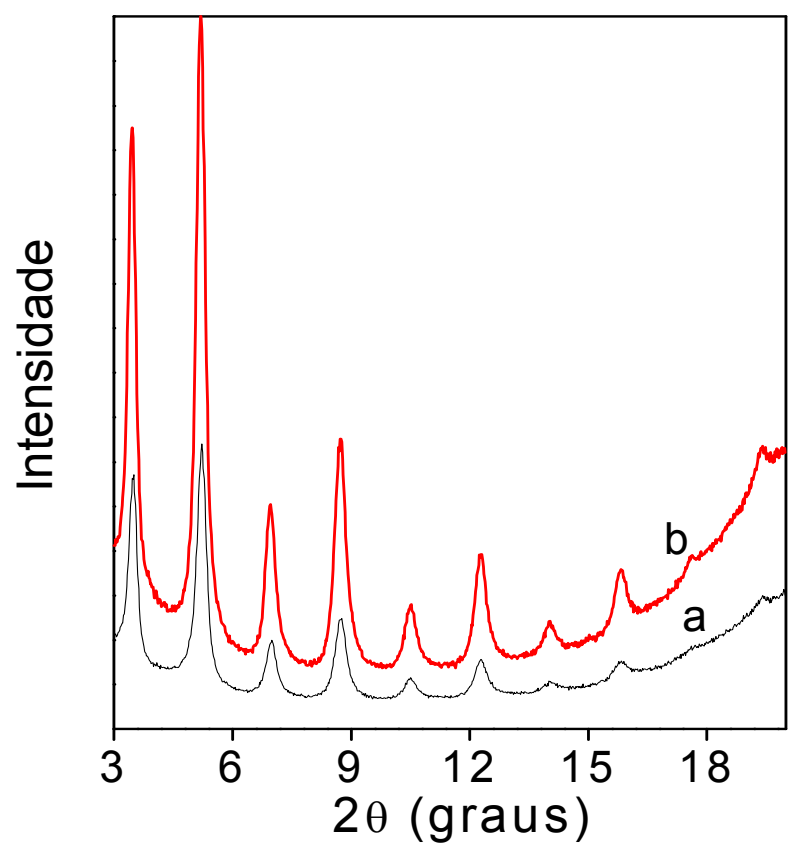

FIGURA 33 - Espectros de difração de raios-X em filmes LB mistos contendo 50\% em massa na solução de PANi/CSA com CdSt. (a) PANi processada na ausência de m-cresol, e (b) PANi processada na presença de m-cresol. 
As intensidades dos picos de refração na Fig. 33 são relativas, visto que as curvas foram aproximadas para comparação. Nota-se que não há variações significativas nos espectros de difração, com uma distância de bicamadas em torno de 50 Å. Portanto, pode-se concluir que as mudanças estruturais na PANi não afetam a ordem de empacotamento dos domínios de estearato de cádmio.

\section{5) Discussão dos resultados}

Como a morfologia do material é determinada pelas condições nas quais a PANi é processada, as possíveis alterações que ocorrem na conformação molecular das cadeias, e na configuração intermolecular entre as cadeias, durante o processamento da polianilina, influenciam as propriedades do polímero em solução, que por sua vez determinarão as características das monocamada. Descobriu-se recentemente que a PANi recém sintetizada, na sua forma de base esmeraldina, existe em uma conformação molecular completamente enovelada. O polímero na forma de pó forma fortes interações do tipo pontes de hidrogênio entre os sítios de nitrogênio amina e imina, ao longo da cadeia, que induz a formação de agregados, no estado não dopado, dificultando muito a solubilidade do material [84-86]. $\mathrm{Na}$ presença de CSA, a protonação dos nitrogênios imina quebra as pontes de hidrogênio ao longo da cadeia, permitindo uma maior interação solvente/polímero, resultando em um aumento de solubilidade da PANi em clorofórmio. Entretanto, como o polímero não dopado é altamente agregado, acredita-se que alguma parte do material recém dopado em uma solução fresca de clorofórmio continue emaranhada devido a interações residuais de pontes de hidrogênio entre diferentes partes da cadeia polimérica [84]. Experimentalmente observa-se a presença de partículas em suspensão na solução quando apenas ácidos funcionalizados, como o CSA, são utilizados para o processamento do material. O "intercruzamento" das cadeias causado pelas pontes de hidrogênio formadas entre as unidades amina e imina gera uma conformação molecular na qual há uma torção entre anéis adjacentes, provocando uma estrutura menos planar entre os anéis benzenóides e quinóides. $\mathrm{Na}$ presença de $m$-cresol e outros materiais como o NMP, essa rede de ligações de pontes de hidrogênio entre diferentes partes de uma mesma cadeia é quebrada. Há então uma relaxação polimérica, facilitando a entrada do solvente, e resultando numa 
conformação molecular mais expandida com uma estrutura mais planar entre os anéis benzenóides e quinóides vizinhos.

O grupo hidroxílico do $m$-cresol interage através de pontes de hidrogênio com o grupo carbonílico do CSA, e os anéis fenílicos na PANi e no $m$-cresol interagem mutuamente através de forças tipo van der Waals, como se houvesse um reconhecimento molecular entre esses materiais para esse tipo específico de interação. Sabe-se que a atração entre dois átomos de carbono é drasticamente menor que aquela devido a ligações de pontes de hidrogênio. Entretanto, se duas moléculas planas, como anéis benzênicos, são apropriadamente colocadas uma sobre a outra, há um aumento na interação resultante porque muitas das interações entre os átomos de carbono acabam ocorrendo simultaneamente. Esse tipo de interação é exatamente o que ocorre entre os anéis da PANi e do $m$-cresol, e o anel benzênico do $m$-cresol sobre a polianilina tem exatamente a dimensão necessária para preencher o espaço vago criado pelos contra-íons do CSA [82]. Essa interação entre os anéis benzênicos é tão forte que a torção da cadeia polimérica faz com que o anel do $m$-cresol deslize sobre o topo de anéis sucessivos ao longo da cadeia da polianilina. Outro aspecto importante é que o grupo metileno entre o grupo sulfônico e a estrutura do anel no CSA permite uma certa flexibilidade que promove o alinhamento nas ligações de ponte de hidrogênio. Esse alinhamento juntamente com a interação entre os anéis da PANi e do $m$-cresol são os requisitos necessários para que haja o reconhecimento molecular entre a PANi, o CSA e o $m$-cresol $[82,83]$, resultando numa expansão da cadeia polimérica e nos melhores resultados de condutividade elétrica em filmes "casting".

No caso da formação de monocamadas sobre subfases líquidas, esperamos que os contra-íons do CSA se difundam na subfase juntamente com o $m$-cresol, que é parcialmente solúvel em água. Tal suposição está baseada nos resultados de FTIR que indicaram a presença apenas de polianilina e CdSt, no caso de filmes mistos. Com isto, há um rearranjo molecular na estrutura do polímero, com a possibilidade de formação de novas pontes de hidrogênio entre os sítios amina e imina, já que o polímero fica parcialmente dopado sobre subfases ácidas, e desdopado no caso dos filmes mistos com estearato de cádmio. Isso implicaria em uma conformação molecular mais enovelada das cadeias sobre a superfície da subfase do que em 
solução. Levando-se em conta ainda que a monocamada é comprimida antes do processo de deposição, a diminuição de área durante a compressão poderia favorecer a formação dessas pontes de hidrogênio no filme de Langmuir. Como se espera que não haja variações drásticas de estrutura do filme de Langmuir para o filme LB, possivelmente as transformações que ocorrem na morfologia das cadeias durante a formação dos filmes de Langmuir sejam responsáveis pelos baixos valores de condutividade elétrica encontrados nos filmes LB. Embora haja o efeito de memória nas monocamadas devido ao uso de $m$-cresol, de alguma forma nos filmes LB as variações que ocorrem devido à compressão da monocamada, e a perda de solvente e dopantes, impliquem em mecanismos não favoráveis para o transporte de cargas nesse tipo de filme. Os espectros de XRD indicam que embora a polianilina sofra variações conformacionais devido à utilização de $m$-cresol, essas alterações não afetam a ordem de empacotamento dos domínios de estearato de cádmio nos filmes LB.

\section{6) Conclus̃̃es}

Monocamadas de polianilina pura e monocamadas mistas de polianilina com estearato de cádmio foram formadas sobre subfases com diferentes propriedades e valores de $\mathrm{pH}$. Apesar da elevada solubilidade do $m$-cresol em subfases aquosas, notou-se que ambos tipos de monocamadas foram alterados devido à presença deste agente plastificante. Os valores de área molecular média são aumentados com a presença de $m$-cresol, indicando um possível efeito de memória. Variações similares foram observadas nas curvas de potencial de superfície. Um desvio no valor máximo de absorção nos filmes LB fabricados quando $m$-cresol é adicionado na solução contendo o polímero revela que o efeito de memória existe, ainda que nenhum traço da presença de $m$-cresol tenha sido detectado pelo espectro de FTIR dos filmes LB de polianilina. Além disso, o uso de $m$-cresol não gerou nenhum aumento significativo nos valores de condutividade elétrica nos filmes LB fabricados até o momento. As possíveis variações conformacionais nas cadeias de PANi não afetaram o ordenamento estrutural dos domínios de estearato de cádmio, como evidenciado pelos resultados de difração de raios-X. 


\section{CAPÍTULO 5}

\section{5) Efeito da exposição de filmes $L B$ mistos de PANi aos raios-X}

\section{1) Introdução}

O nível de dopagem é um parâmetro crucial para as propriedades de transporte da polianilina, que são por sua vez dramaticamente afetadas pelo nível de protonação. $\mathrm{O}$ controle desses parâmetros torna-se fundamental para aplicações, e a possibilidade de dopagem sem a exposição do polímero a substâncias químicas pode vir a ser de grande valia na fabricação de dispositivos eletrônicos. De qualquer forma, independentemente do tipo de aplicação que se queira, as propriedades elétricas da PANi são essencialmente modificadas pela quantidade residual de água nos poros da matriz polimérica [87-92]. Estudos anteriores mostraram que a exposição de filmes "casting" de polianilina aos raios-X $[10,11]$ leva a uma transição isolante/condutor, com um aumento de dez ordens de grandeza nos valores de condutividade elétrica. Em outro trabalho, a exposição de polianilina, na presença de sal trifenil sulfônico hexafluoratimonado, à radiação ultravioleta e a feixes de elétrons induziu um efeito de dopagem semelhante no polímero [93].

Neste capítulo apresentaremos os resultados da exposição aos raios- $X$ de filmes LB mistos de polianilina com estearato de cádmio, variando-se o tempo de irradiação, e a atmosfera em que se realiza a experiência. Antes de qualquer irradiação nas amostras, foram feitas medidas de UV-vis para uma análise qualitativa mais acurada dos resultados.

\section{2) Parte experimental}

Filmes mistos de polianilina com estearato de cádmio foram preparados a partir dos procedimentos relatados nos capítulos 2 e 3. Para obter filmes LB de polianilina e ácido esteárico, a solução preparada foi espalhada sobre a superfície da água ultrapura apenas, sem a adição de $\mathrm{NaHCO}_{3}$ e $\mathrm{CdCl}_{2}$. Todos os filmes $\mathrm{LB}$ foram 
depositados apenas de um lado do substrato com a finalidade de evitar ou minimizar possíveis discrepâncias nas medidas de UV-vis.

Os estudos anteriores das isotermas e da estabilidade dos filmes de Langmuir revelam a formação de uma monocamada mista estável e condensada, o que permitiu a deposição dos filmes sobre placas de quartzo e fluoreto de cálcio $\left(\mathrm{CaF}_{2}\right)$, com TRs próximas da unidade. $\mathrm{O}$ quartzo foi escolhido devido ao fato de não haver nenhuma alteração de cor nos substratos após um tempo relativamente longo ( 36 horas) de exposição aos raios-X. O mesmo não ocorre com o vidro que se torna levemente colorido após um certo tempo de irradiação (menor que duas horas). Os substratos de fluoreto de cálcio foram utilizados para monitorar o efeito da exposição aos raios-X, através da técnica de FTIR. Os mesmos tornaram-se esverdeados após um certo tempo de irradiação ( $\sim 2$ horas). A radiação foi produzida através de um gerador de raios-X Müller MG 150 (Phillips) com uma voltagem de tubo de $75 \mathrm{kV}$ e corrente de $15 \mathrm{~mA}$. A radiação gerada tem um pico em torno de $0.4 \AA$. Um feixe uniforme com uma taxa de 9,5 Gy/s foi direcionado sobre as amostras, que estavam distantes $8 \mathrm{~cm}$ da fonte. Os experimentos foram realizados à temperatura ambiente, em diferentes atmosferas de medida. Para tanto utilizou-se uma câmara fechada, fabricada no Grupo de Polímeros Prof. Bernhard Gross (IFSC/USP), para obter um ambiente de vácuo ( $\sim 10^{-4}$ Torr). As atmosferas de oxigênio, nitrogênio e argônio foram obtidas após a obtenção de vácuo, injetando posteriormente os gases no interior da câmara. $\mathrm{O}$ controle de umidade dessas atmosferas foi feito ligando a saída da câmara a um erlenmeyer. No interior desse recipiente colocou-se o medidor de umidade (termohigrômetro produzido pela IOPE Instrumentos, modelo 10PH-FA-2), e após um intervalo de tempo de aproximadamente uma hora realizou-se a medida. Em atmosfera ambiente o controle de umidade é feito colocando-se a amostra no interior de um recipiente plástico tipo "tuperware", com alguns béqueres cheios de água. Em alguns deles era adicionada a quantidade adequada de cloreto de sódio para a percentagem de umidade desejada [94]. Foi feita uma janela de poli(etileno teraftalato) (PET) na tampa superior do "tuperware" para exposição dos filmes LB aos raios-X. Escolheu-se o PET devido à sua resistência mecânica e transparência, e ainda porque o sistema foi calibrado utilizando uma folha de PET a $8 \mathrm{~cm}$ de distância da fonte de raios-X, para diferentes valores de tensão e corrente no tubo de raios-X. 
Esse material apresenta ainda resistência a degradação para intervalos de exposição aos raios-X relativamente longos, ou seja, a absorção de radiação pela folha de PET é insignificante. Medidas de UV-vis, FTIR, difração de raios-X e condutividade elétrica (pelo método de van der Pauw) foram realizadas para caracterização das amostras.

\section{3) Resultados e Discussão}

Foram produzidas amostras com diferentes números de camadas depositadas, sobre substratos de quartzo, para posterior irradiação. Os filmes LB foram expostos sistematicamente aos raios- $\mathrm{X}$, durante determinados intervalos de tempo, com os espectros de UV-vis obtidos imediatamente após a exposição à irradiação. A Figura 34 mostra o espectro de UV-vis de um filme LB recém depositado, contendo 21 camadas, irradiado em atmosfera ambiente ( 50\% de umidade), em diferentes intervalos de tempo.

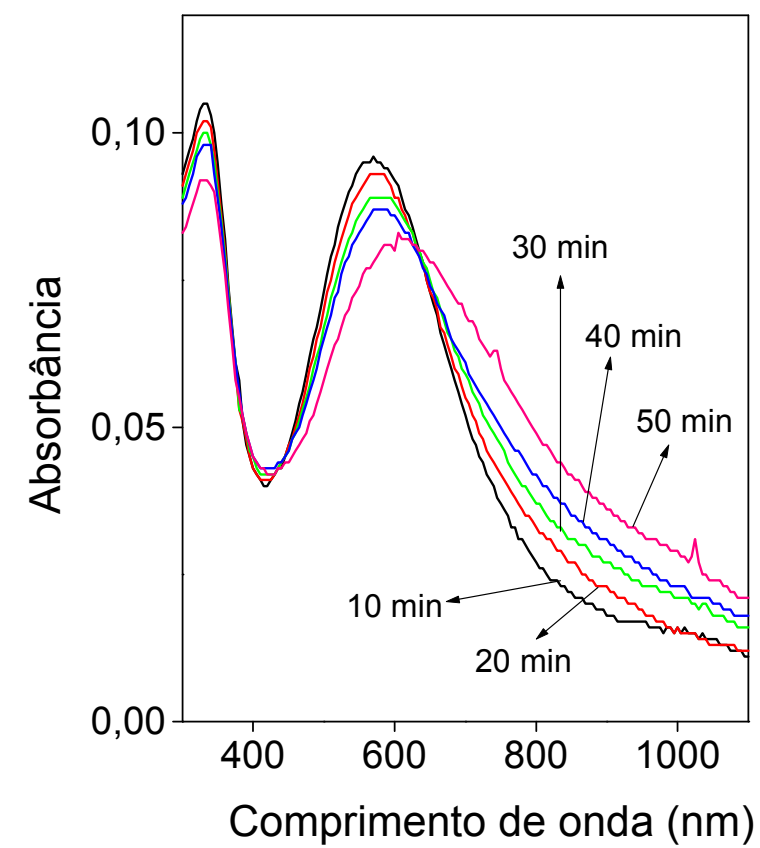

FIGURA 34 - Espectros de UV-vis para filmes LB mistos de polianilina com estearato de cádmio (21 camadas) durante os estágios iniciais de irradiação, em atmosfera ambiente $(\sim 50 \%$ de umidade).

Os filmes recém depositados possuem duas bandas de absorção características, uma em $320 \mathrm{~nm}$, característica das transições $\pi$ - $\pi^{*}$, e a outra em 580 $\mathrm{nm}$, característica das transições excitônicas. A presença desses dois picos revela que 
a polianilina está desdopada na sua forma de base esmeraldina [29]. Após a exposição aos raios-X ambas as absorções em $320 \mathrm{~nm}$ e $580 \mathrm{~nm}$ decrescem, ocorrendo um aumento de absorção na região de comprimentos de onda maiores (> $700 \mathrm{~nm}$ ), após uma hora de exposição. Na Figura 34 nota-se a presença de pontos isobésticos em $350 \mathrm{~nm}$ e $650 \mathrm{~nm}$, indicando uma variação sistemática e contínua na estrutura eletrônica da polianilina, o que possivelmente pode estar associada a variações conformacionais nas cadeias poliméricas. O máximo de absorção em 580 $\mathrm{nm}$ foi deslocado para o vermelho na região visível do espectro de UV-vis com um tempo de exposição de apenas vinte a trinta minutos. Entretanto, mantendo-se a irradiação por um período de duas a três horas (dose $\sim 6.10^{4}$ a $10^{5} \mathrm{~Gy}$ ), como mostrado na Figura 35, um deslocamento do máximo de absorção em torno de 800 $\mathrm{nm}$ pode ser verificado, ocorrendo ainda uma mudança de cor no filme LB de azul para o verde, característico do estado dopado da polianilina, mantendo-se invariável quando o tempo de irradiação é aumentado ( 6 horas). A intensidade das bandas de absorção também não é alterada significativamente com o aumento do tempo de irradiação.

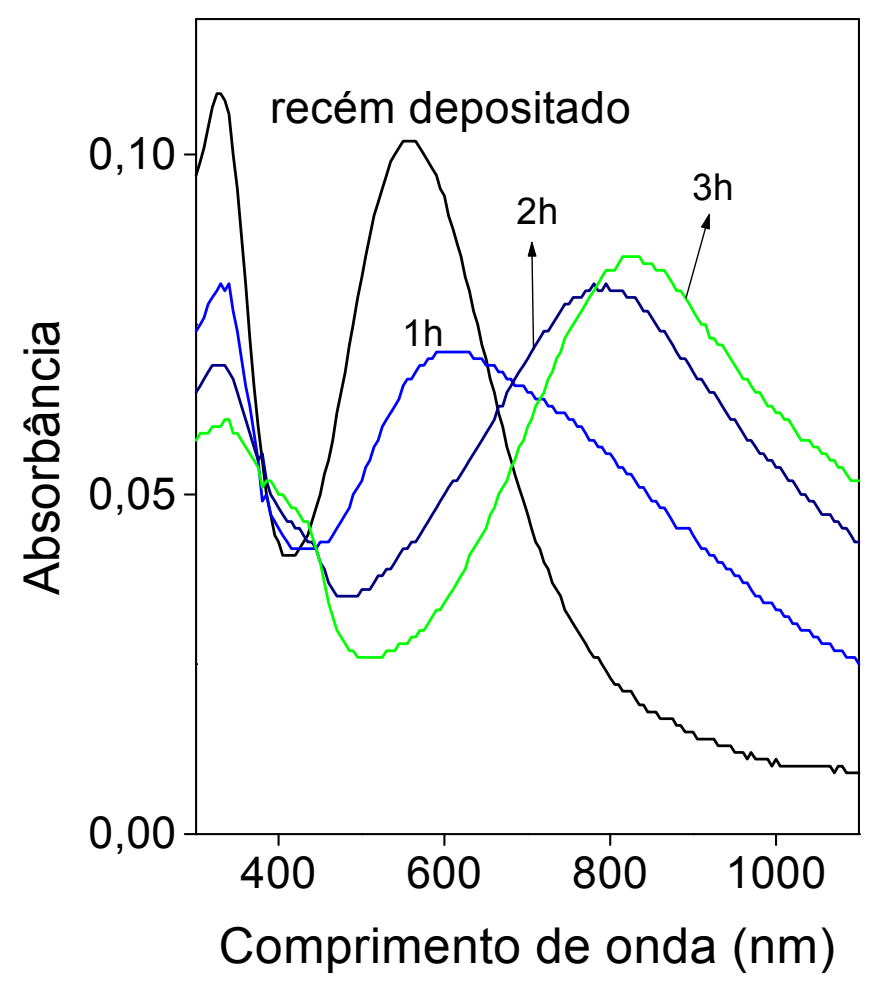

FIGURA 35 -Espectros de UV-vis para filmes mistos de polianilina com estearato de cádmio (21 camadas), irradiados em atmosfera ambiente ( $50 \%$ de umidade), após um tempo prolongado de irradiação. 
É possível que o processo inteiro envolva dois passos. O primeiro no qual há um decréscimo nas bandas de absorção nas regiões de 320 e $580 \mathrm{~nm}$, acompanhado por um aumento na absorção na região de comprimentos de onda maiores, após um intervalo de irradiação de aproximadamente uma hora. O decréscimo de intensidade na banda de absorção em $320 \mathrm{~nm}$ ocorre também devido ao aumento na protonação em filmes de PANi dopados com ácidos inorgânicos [95,96]. O segundo no qual o máximo de absorção é claramente deslocado para o vermelho $(\sim 800 \mathrm{~nm})$, atingindose uma saturação a partir da qual o espectro mantém-se invariável com o aumento do tempo de exposição. Visualmente os filmes apresentam-se uniformes mesmo após um tempo prolongado de irradiação (6 horas). A presença de pontos isobésticos e a ausência de um forte decréscimo na absorção podem indicar que não há nenhum efeito significativo de degradação da polianilina sob irradiação de raios-X, pelo menos no período de tempo aplicado no presente estudo. Não foi notada nenhuma alteração relevante quanto a forma dos espectros de UV-vis devido ao armazenamento dos filmes em atmosfera ambiente, por várias semanas, indicando a irreversibilidade desse processo em filmes LB de PANi. Para verificar se há algum efeito proveniente dos átomos de cádmio, conhecidos como bom espalhadores de raios-X, realizou-se um experimento com filme LB de PANi e ácido esteárico, para efeito de comparação. Os resultados obtidos são praticamente idênticos àqueles observados com os filmes LB de polianilina com estearato de cádmio, indicando que a presença de cádmio não possui nenhum efeito digno de nota.

As variações nos filmes LB foram acompanhadas através dos espectros de FTIR, como mostrado na Figura 36. Além dos picos característicos dos grupos metileno, em 2918 e $2849 \mathrm{~cm}^{-1}$, correspondentes ao estiramento simétrico e anti-simétrico, respectivamente, do grupo $\mathrm{CH}_{2}$, e um pico fraco em $1470 \mathrm{~cm}^{-1}$ (vibrações angulares do $\mathrm{CH}_{2}$ ), os filmes recém depositados possuem uma forte absorção em $1546 \mathrm{~cm}^{-1}$, característica das vibrações axiais C-O dos grupos carboxílicos ionizados, confirmando a presença de CdSt nos filmes LB [27,65]. Juntamente com a ausência de absorção em $1700 \mathrm{~cm}^{-1}$, o último resultado indica que os filmes mistos de PANi com CdSt contêm, principalmente, sais de estearato, sem a presença de ácido esteárico não ionizado. Os picos característicos correspondentes à base esmeraldina da polianilina podem ser verificados em 1596 (estiramento das 
ligações $\mathrm{C}=\mathrm{C}$ dos anéis quinóides), 1330 (estiramento das ligações $\mathrm{C}-\mathrm{N}$ de anéis benzênicos e quinóides), e 1150 (combinações de vibrações axiais e angulares da estrutura quinóide) $[27,36,65]$. Mesmo após três horas de irradiação, correspondendo a uma dose de $10^{5} \mathrm{~Gy}$, nenhuma variação relevante foi notada nos picos de absorção correspondentes ao estearato de cádmio. A intensidade e os valores correspondentes aos picos metileno e carbonílico indicam possivelmente que não há nenhuma degradação apreciável ou mudança significativa na ordem estrutural dos domínios de estearato de cádmio. Observou-se, também, que após a irrradiação os picos correspondentes à polianilina tornam-se mais intensos, com o pico em $1330 \mathrm{~cm}^{-1}$ ficando ligeiramente deslocado para o vermelho. As pequenas alterações no espectro de FTIR, mostrados na Figura 36, devido à irradiação, são similares àquelas observadas durante a dopagem ácida da polianilina. Tais variações têm sido relacionadas ao aumento dos momentos de dipolo moleculares com a criação de cargas positivas nas unidades amina e imina da polianilina [27]. Entretanto, a maior diferença observada com os filmes LB expostos aos raios-X, em comparação com os filmes dopados quimicamente, foi a ausência de um aumento na absorção na região de 4000 a $1600 \mathrm{~cm}^{-1}$, que tem sido normalmente atribuída à formação de portadores de carga [27].

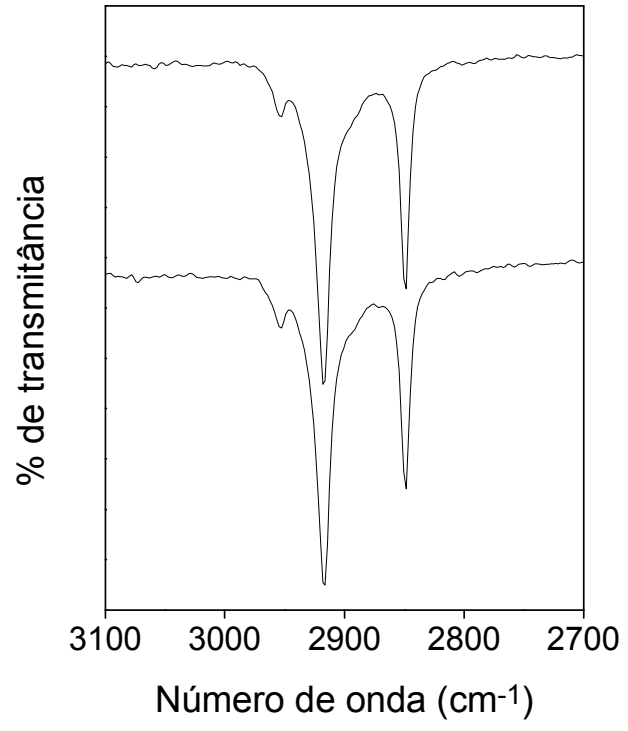

Figura 36a

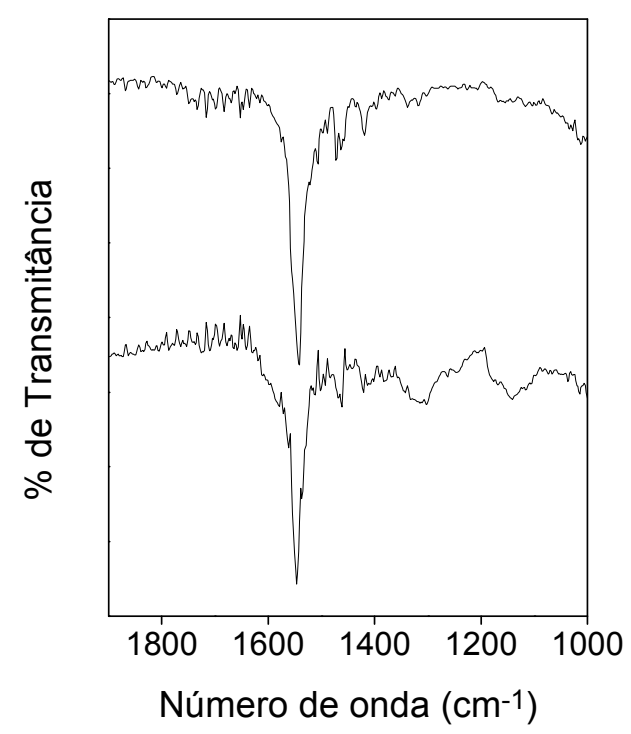

Figura 36b

FIGURA 36 - Espectros de FTIR de filmes LB mistos de polianilina com CdSt: (a) recém depositados $e$ (b) expostos aos raios-X por 3 horas em atmosfera ambiente ( $50 \%$ de umidade)

Figura 36a - região de 3110 - $2700 \mathrm{~cm}^{-1}$

Figura 36b - região de 1900 - $1000 \mathrm{~cm}^{-1}$. 
Para confirmar a preservação dos domínios de estearato de cádmio na estrutura dos filmes LB, variações devido à exposição dos filmes aos raios-X foram acompanhadas através de XRD, como mostrado na Figura 37.

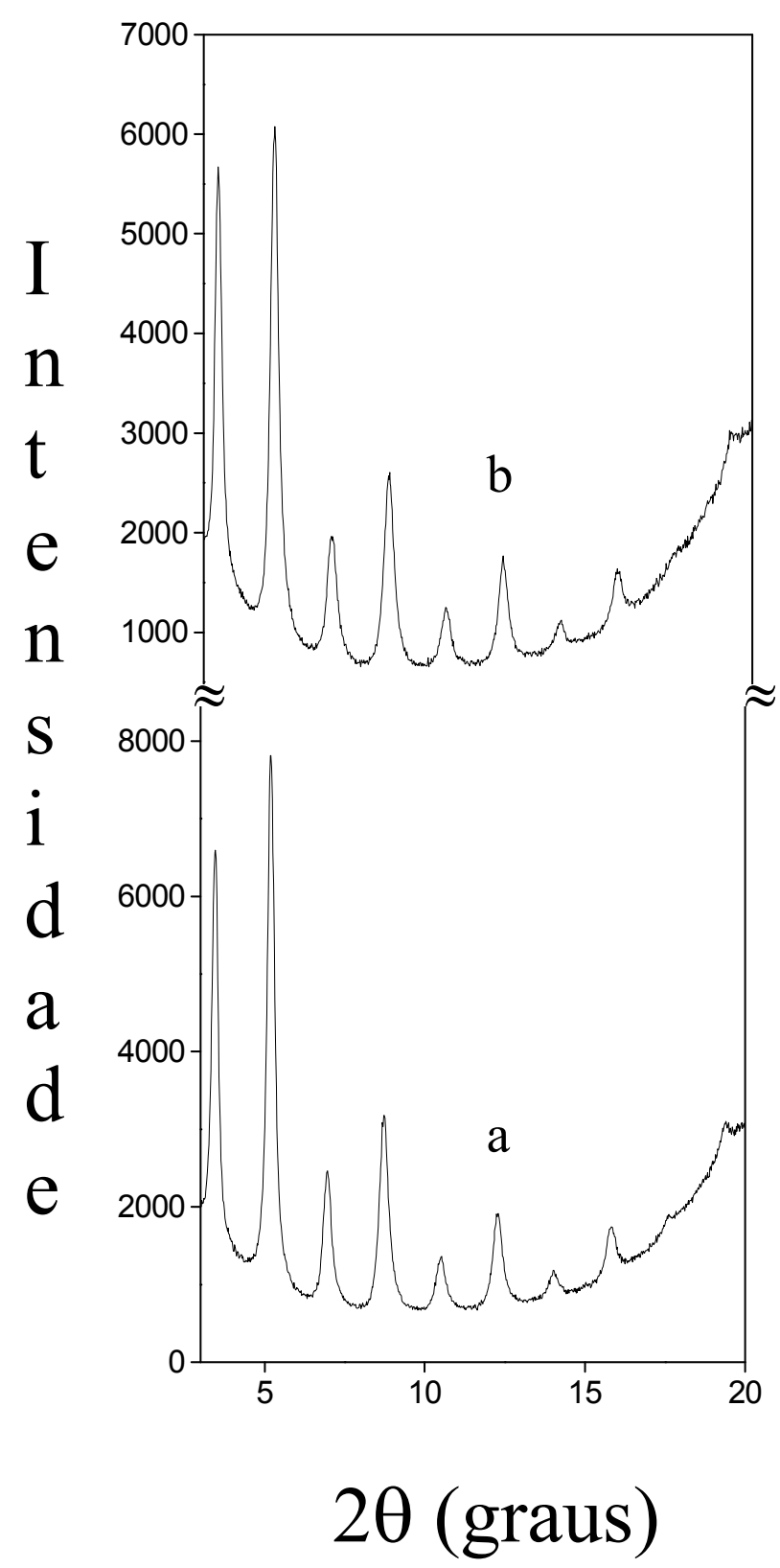

FIGURA 37 - Espectro de difração de raios-X de filmes LB mistos de polianilina com CdSt. (a) recém depositado, e (b) irradiado por 3 horas em atmosfera ambiente ( $50 \%$ de umidade).

Os filmes LB recém depositados (curva a) mostraram um intenso grupo de picos de difração com uma distância de bicamadas de $(50,6 \pm 0,5 \AA)$, indicando a presença de domínios de estearato de cádmio distribuídos na matriz de PANi. É interessante notar que o padrão de XRD para os filmes mistos de $\mathrm{PANi} / \mathrm{CdSt}$ não é 
alterado mesmo após 6 horas de irradiação (curva b). Comparando as curvas a e b, é de se notar que o empacotamento das moléculas de CdSt foi preservado, ainda que se saiba que as variações nas características eletrônicas da polianilina sejam acompanhadas por variações estruturais. Com isto conclui-se que a ordem de empacotamento dos domínios de CdSt não foi alterada de forma significativa.

Como o efeito da umidade nos resultados obtidos em filmes casting $[10,11]$ é significativo, foram irradiados filmes LB contendo 84 camadas, a atmosfera ambiente e a 90\% de umidade. Os resultados são ilustrados nas Figuras 38 e 39.

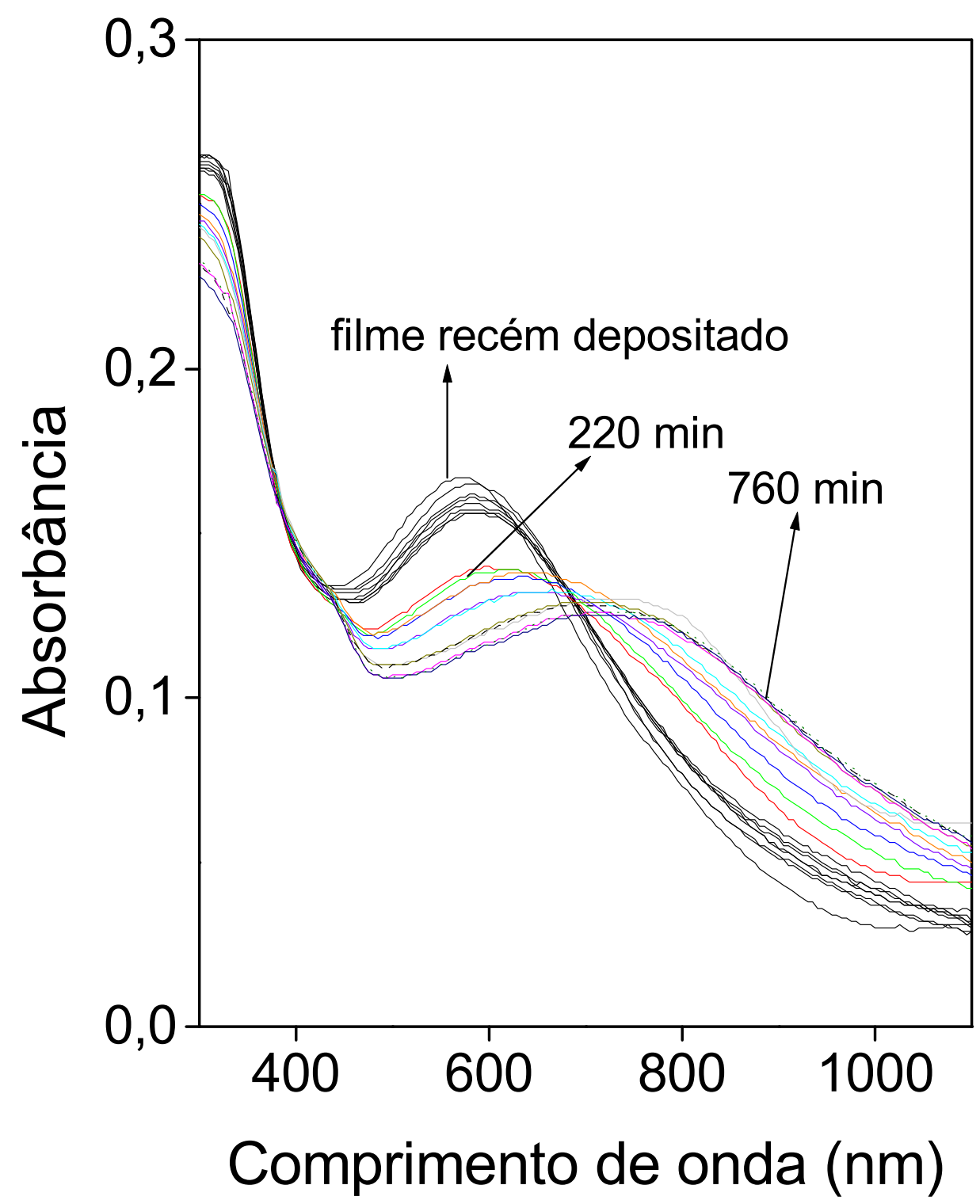

FIGURA 38 - Espectros UV-vis para um filme LB contendo 84 camadas irradiado a atmosfera ambiente ( $50 \%$ de umidade) em diferentes intervalos de tempo, num total de 760 minutos de irradiação. 


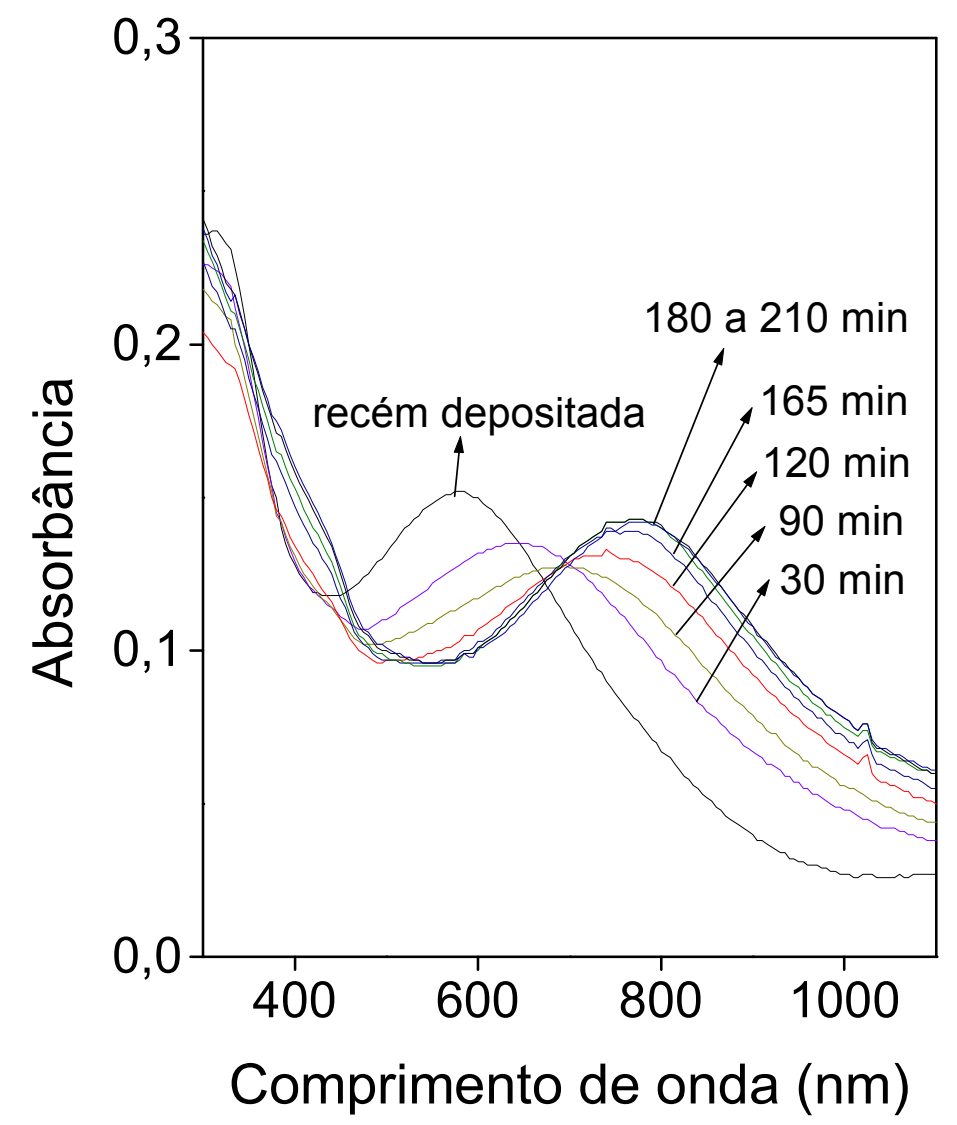

FIGURA 39 - Espectros UV-vis para um filme LB contendo 84 camadas irradiado em atmosfera ambiente a 90\% de umidade, em diferentes intervalos de tempo, num total de 210 minutos de irradiação.

Como pode ser observado na Fig. 38, após irradiar a amostra por 220 minutos, em atmosfera ambiente a $50 \%$ de umidade (curva verde na Fig. 38), há o início do deslocamento da banda de absorção para a região de comprimentos de maiores. Mesmo assim deve ser mencionado que para esse tempo de exposição aos raios-X o máximo de absorção está na região de $600 \mathrm{~nm}$, indicando o estado não dopado do polímero. Em uma atmosfera a $90 \%$ de umidade ocorre o aparecimento da banda de absorção polarônica $(800 \mathrm{~nm})$ para um intervalo de irradiação menor $(\sim 180$ minutos), como observado na Fig. 39. Os pequenos picos observados nessa figura são devidos a problemas de calibração no equipamento de UV-vis, durante a realização das medidas. É interessante notar que o efeito de umidade nas variações causadas pela exposição de filmes LB de PANi aos raios-X é o mesmo que o relatado na literatura para filmes mais espessos $[10,11]$.

A fim de comprovar se a transição nos espectros de UV-vis deve-se ou não à umidade presente na atmosfera de medida, foram irradiados, durante um intervalo de 
tempo de 45 minutos, filmes LB contendo 13 camadas em diferentes atmosferas de medida. Os resultados são mostrados nas Figuras 40, 41, 42 e 43 abaixo.

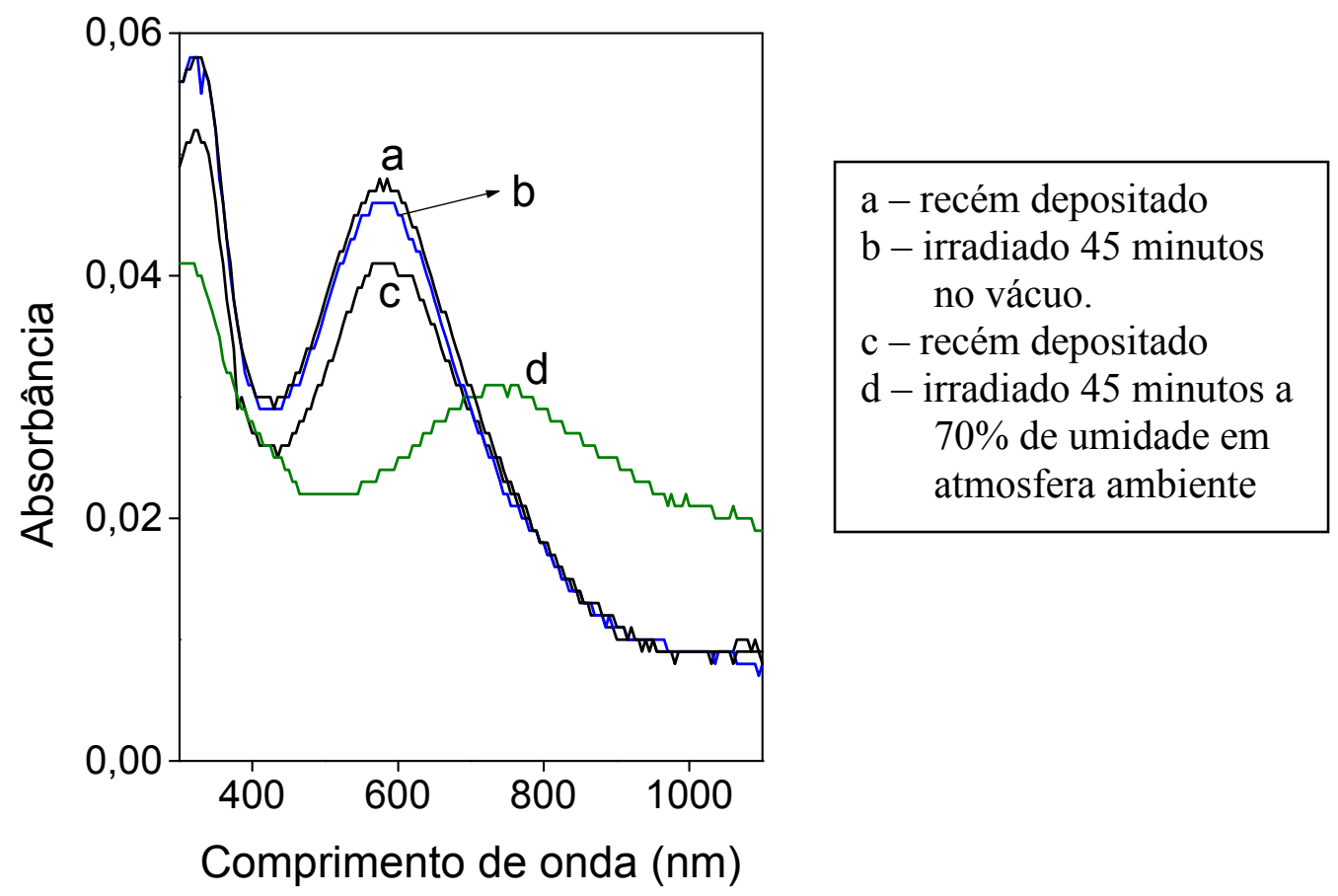

FIGURA 40 - Espectros UV-vis para filmes LB de PANi contendo 13 camadas, irradiados durante 45 minutos no vácuo e em atmosfera ambiente a $70 \%$ de umidade.

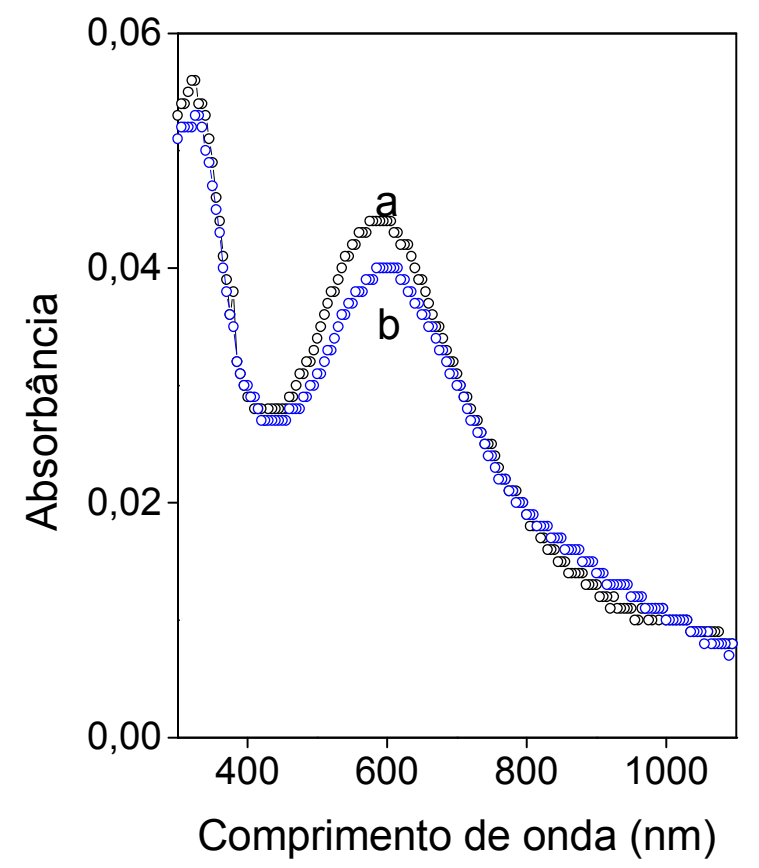

FIGURA 41 - Espectros UV-vis para filmes LB de PANi contendo 13 camadas em atmosfera de oxigênio. a) recém depositado; b) irradiado 45 minutos 


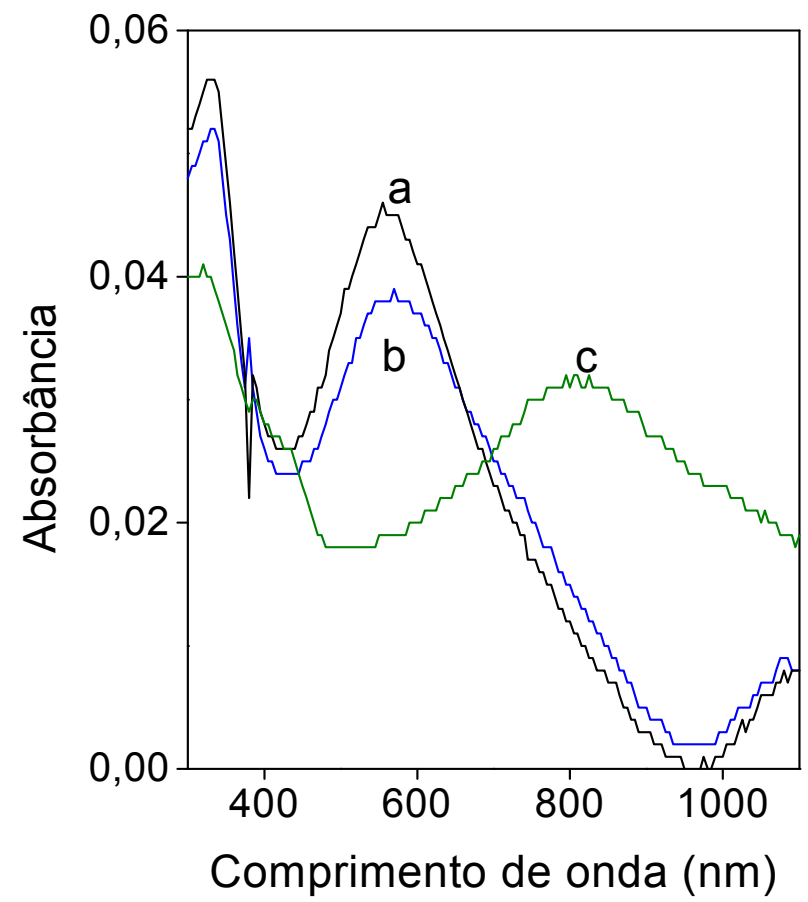

FIGURA 42 - Espectros UV-vis para filmes LB de PANi contendo 13 camadas em atmosfera de nitrogênio. a) recém depositado; b) irradiado 45 minutos em atmosfera de nitrogênio super-seco; c) irradiado 45 minutos em atmosfera de nitrogênio a 84\% de umidade.

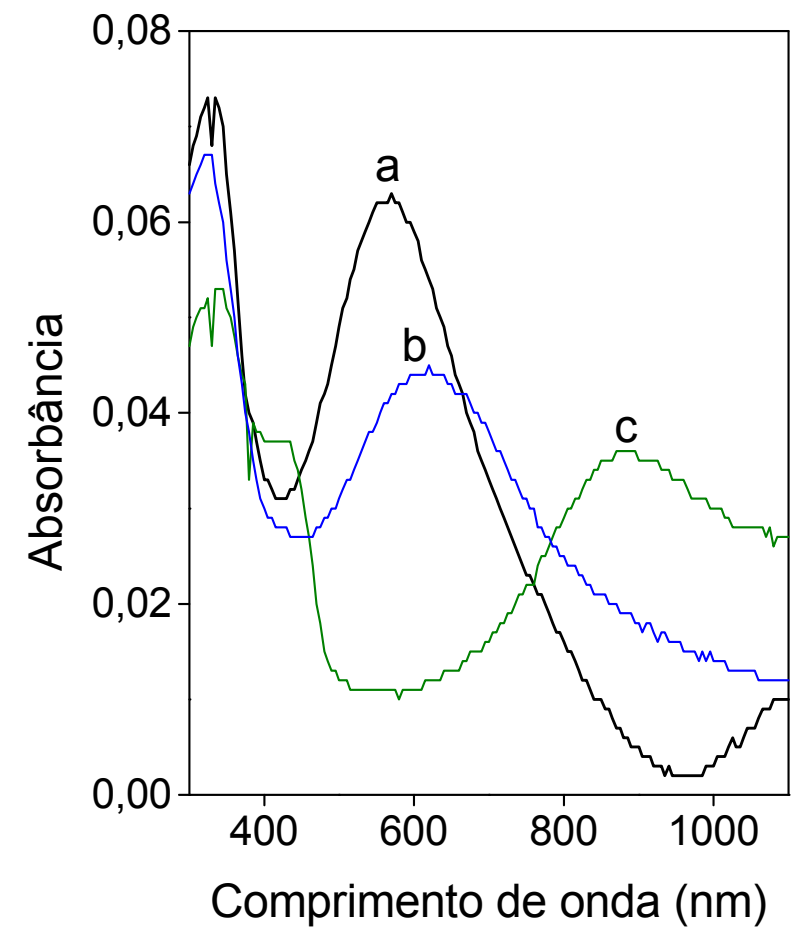

FIGURA 43 - Espectros UV-vis para filmes LB de PANi contendo 13 camadas em atmosfera de argônio. a) recém depositado; b) irradiado 45 minutos em atmosfera de argônio; irradiado 45 minutos em atmosfera de argônio a 85\% de umidade. 
A diferença na intensidade da banda de absorção (600 nm) observada na Fig. 40 para os filmes recém depositados pode ser atribuída aos problemas encontrados durante a fabricação dos filmes LB, o que impossibilita garantir filmes exatamente iguais. Ou seja, é uma dispersão própria de filmes distintos, ainda que obtidos sob as mesmas condições. Se a superfície do substrato não estiver adequadamente limpa, por exemplo, haverá uma menor adesão da monocamada, implicando em uma absorbância menor.

Em atmosferas de oxigênio, nitrogênio, argônio e no vácuo os filmes irradiados continuam apresentando a banda de absorção na região de $600 \mathrm{~nm}$ para o intervalo de exposição (45 minutos) utilizado. Nessas medidas a umidade relativa nas atmosferas de oxigênio, nitrogênio super-seco e argônio era inferior a $2 \%$. Deve-se notar que em atmosfera de argônio, quando comparado com os outros gases, ocorre um deslocamento maior da banda de absorção para a região de comprimentos de onda maiores. Entretanto, para o filme irradiado em atmosfera ambiente a 70\% de umidade, há o desaparecimento da banda da região de $600 \mathrm{~nm}$ com o concomitante aparecimento da banda polarônica, para o mesmo intervalo de exposição aos raios-X. Observa-se também nessas figuras que os filmes LB expostos a ambientes úmidos em atmosferas de nitrogênio e argônio (45 minutos de irradiação) apresentam a banda de absorção na região de $800 \mathrm{~nm}$.

Pode-se observar na Figura 44 que o comportamento de um filme LB com apenas 13 camadas, irradiado durante 45 minutos em atmosfera de oxigênio, mantido por dezoito horas em atmosfera ambiente (50\% de umidade), e, posteriormente irradiado por mais noventa minutos em atmosfera de oxigênio, difere daquele para um filme LB (13 camadas) exposto aos raios-X a 70\% de umidade, em atmosfera ambiente (Fig. 40d). Verifica-se que em atmosfera de oxigênio, mesmo para um intervalo de exposição maior, o processo é mais lento. A simples exposição do filme LB a um ambiente mais úmido é suficiente para causar um pequeno deslocamento no espectro de absorção, mesmo antes de expor novamente o filme aos raios-X por mais noventa minutos. Esse efeito será comentado posteriormente. 


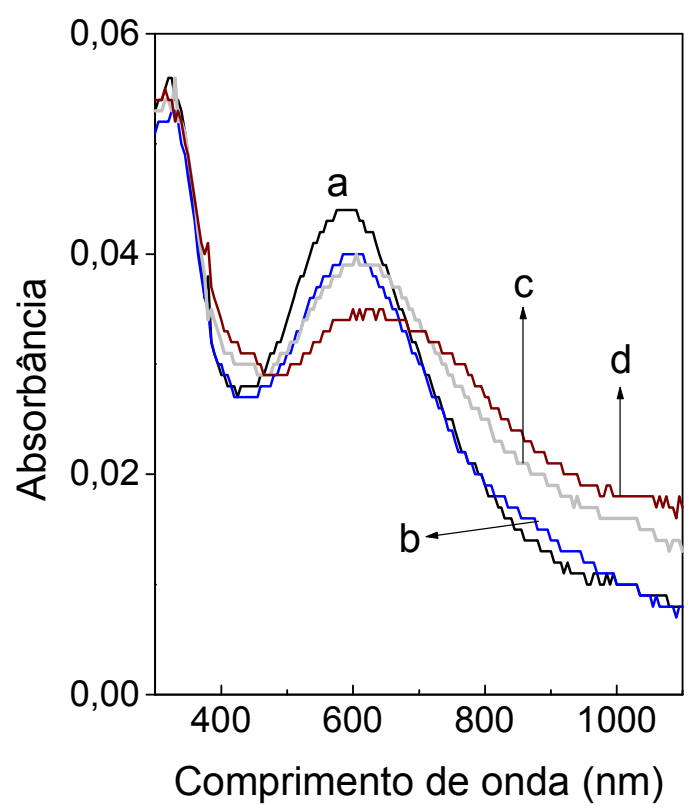
a - recém depositado
b - irradiado por 45 min em atmosfera de oxigênio
c - mantido por $18 \mathrm{~h}$ em atmosfera ambiente
d - irradiado por $90 \mathrm{~min}$ em atmosfera de oxigênio

FIGURA 44 - Variação no espectro de UV-vis em um filme LB de PANi contendo 13 camadas, em atmosfera de oxigênio.

Outra hipótese analisada foi verificar se havia ou não variações nos espectros de UV-vis, alterando-se a espessura do filme LB, mas mantendo-se fixa a umidade $(90 \%)$ da atmosfera de medida. As Fig 45, 46 e 47 ilustram as variações nos espectros de UV-vis em filmes LB contendo 11, 40 e 120 camadas depositadas, respectivamente.

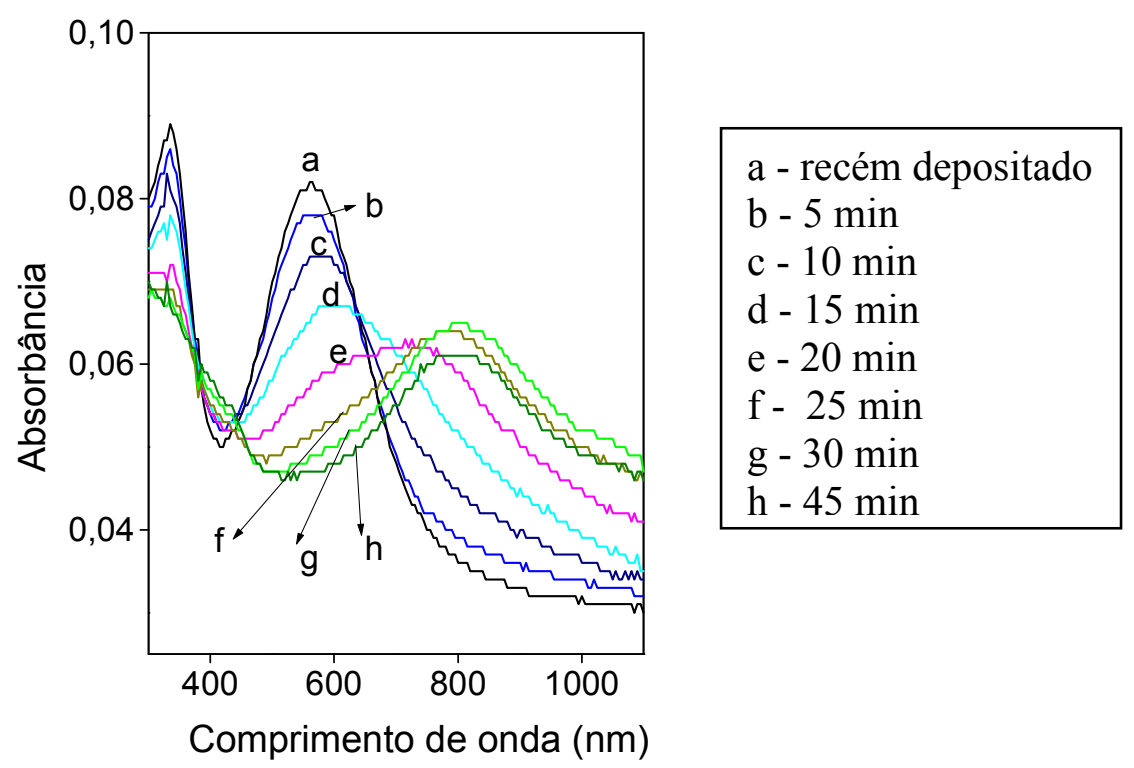

FIGURA 45 - Espectros UV-vis para um filme LB contendo 11 camadas irradiado em atmosfera ambiente a 90\% de umidade, em diferentes intervalos de tempo, num total de 45 minutos de irradiação. 


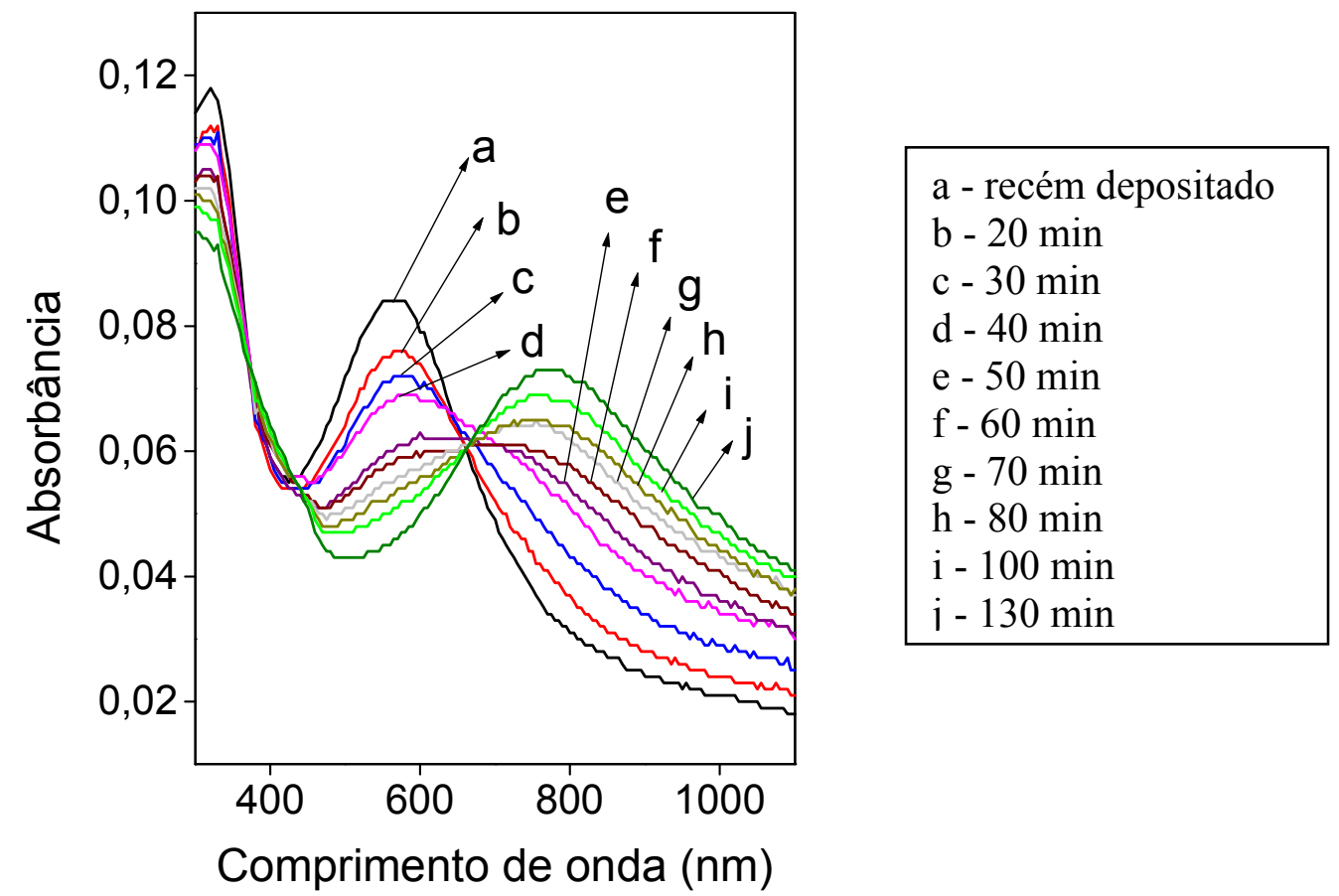

FIGURA 46 - Espectros UV-vis para um filme LB contendo 40 camadas irradiado em atmosfera ambiente a 90\% de umidade, em diferentes intervalos de tempo, num total de 130 minutos de irradiação.

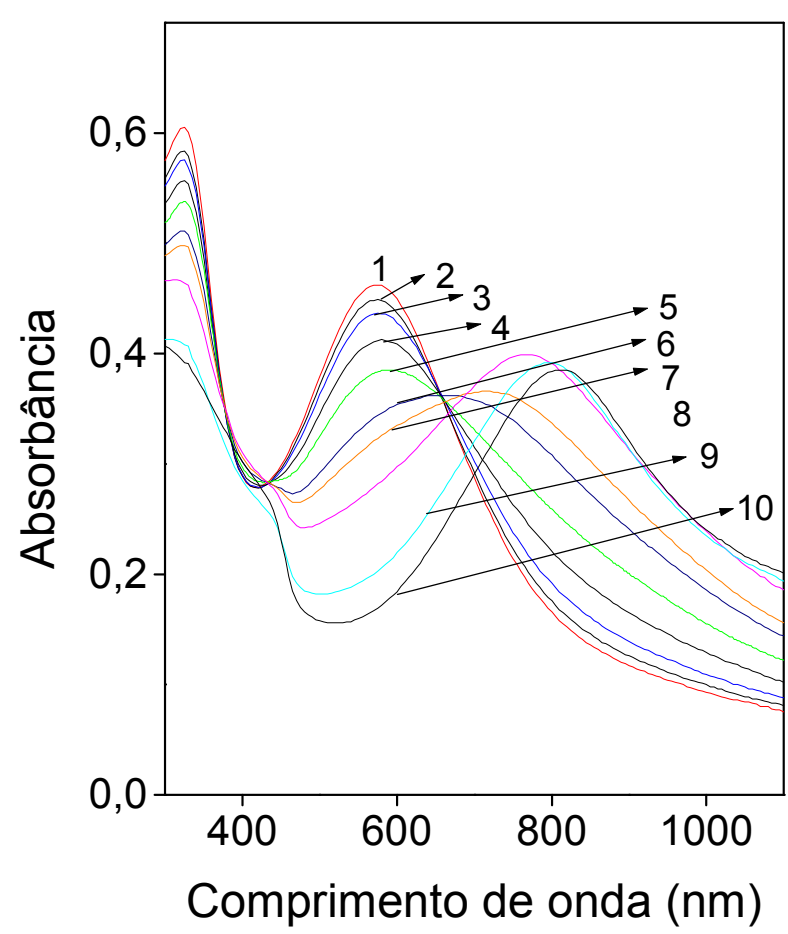

1 - recém depositado

2 - $20 \mathrm{~min}$

$3-40 \mathrm{~min}$

$4-70 \mathrm{~min}$

$5-100 \mathrm{~min}$

$6-130 \mathrm{~min}$

7 - $160 \mathrm{~min}$

8 - $220 \mathrm{~min}$

9 - $280 \mathrm{~min}$

$10-340 \mathrm{~min}$

FIGURA 47 - Espectros UV-vis para um filme LB contendo 120 camadas irradiado em atmosfera ambiente a $90 \%$ de umidade, em diferentes intervalos de tempo, num total de 340 minutos de irradiação. 
Observando as Fig. 39, 45, 46 e 47 verifica-se que há quatro filmes LB com diferentes números de camadas depositadas, sob as mesmas condições de irradiação, a 90\% de umidade. A amostra com 11 camadas atinge o estado dopado (região de $800 \mathrm{~nm}$ no espectro de UV-vis) após 25 min de exposição aos raios-X. O filme com 40 camadas atinge o mesmo estado após 80 minutos de irradiação, enquanto o filme com 84 camadas atinge a região de $800 \mathrm{~nm}$ após 160 minutos de exposição. Para o filme mais espesso (120 camadas) são necessários 220 minutos de irradiação. Verifica-se desta forma que dependendo da espessura do filme LB atinge-se a banda polarônica em intervalos distintos de exposição aos raios-X, mantendo-se fixa a umidade relativa do ambiente de medida. Há uma dependência linear entre o tempo necessário para a aparição da banda de absorção na região de $800 \mathrm{~nm}$ no espectro de UV-vis, e a espessura do filme LB, como mostrado na Figura 48 a seguir.

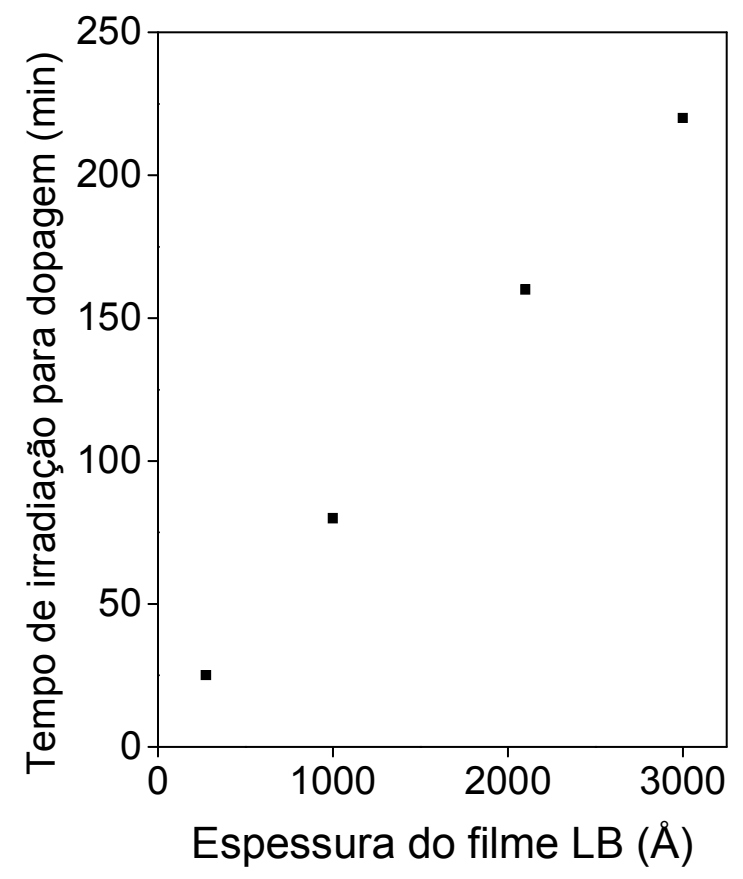

FIGURA 48 - Variação do tempo necessário para o aparecimento da banda de absorção polarônica nos espectro de UV-vis em função de espessura de filmes $L B$ de PANi/CdSt, irradiados a $90 \%$ de umidade, em diferentes intervalos de tempo.

Devido à importância dos efeitos de dopagem na polianilina pela exposição ao vapor de $\mathrm{HCl}$, decidiu-se verificar se haveria variações nos espectros de UV-vis em filmes LB irradiados antes e depois da dopagem por $\mathrm{HCl}$. Primeiro irradiou-se em atmosfera ambiente ( $\sim 50 \%$ de umidade) um filme LB contendo 19 camadas e, posteriormente, expôs-se esse filme por 10 minutos ao vapor de $\mathrm{HCl}$. Para efeito de 
comparação expôs-se outro filme LB recém depositado, também com 19 camadas, ao vapor de $\mathrm{HCl}$ e, posteriormente, irradiou-se esse filme em atmosfera ambiente durante 2 horas. Os resultados podem ser observados na Figura 49 a seguir.

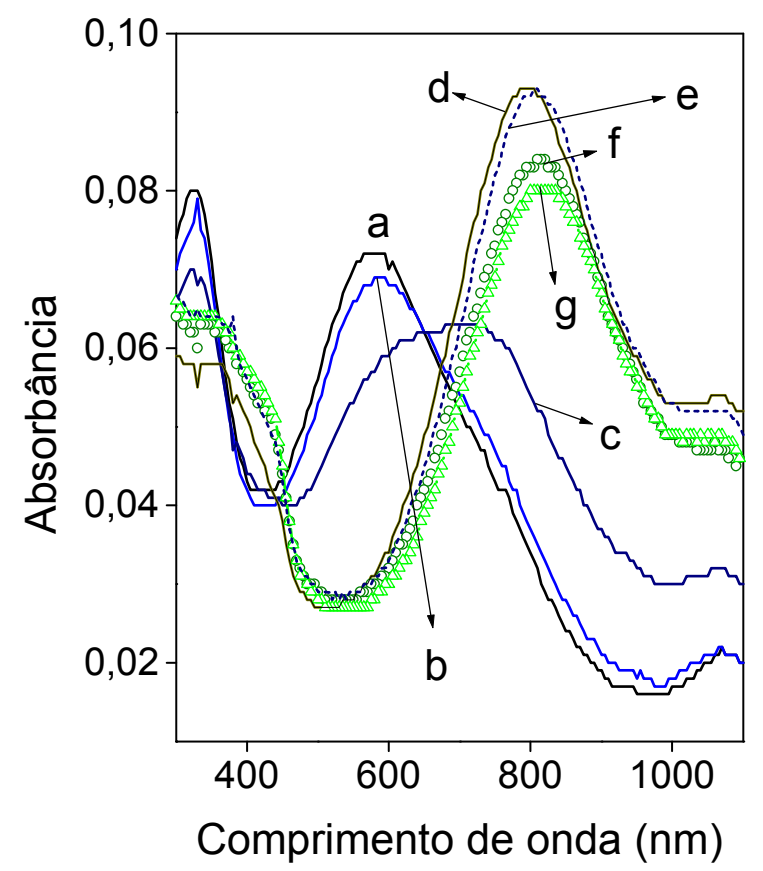

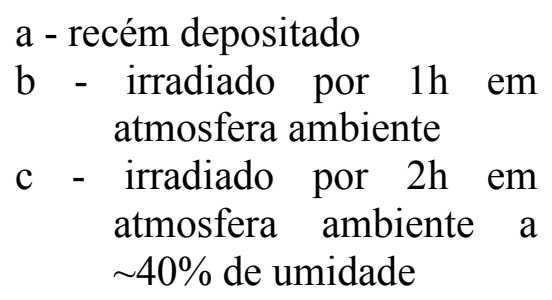
atmosfera ambiente

c - irradiado por $2 \mathrm{~h}$ em atmosfera ambiente a $\sim 40 \%$ de umidade

$\mathrm{d}$ - exposto ao vapor de $\mathrm{HCl}$ (10 min) após irradiar $2 \mathrm{~h}$

e - exposto ao vapor de $\mathrm{HCl}$ sem prévia irradiação

$\mathrm{f}$ - filme $e$, irradiado por $1 \mathrm{~h}$ em atmosfera ambiente

$\mathrm{g}$ - filme $e$, irradiado por $2 \mathrm{~h}$ em atmosfera ambiente

FIGURA 49 - Efeito de dopagem ao vapor de $H C l$, e efeitos de exposição aos raios-X num filme LB contendo 19 camadas depositadas

A exposição do filme $\mathrm{LB}$ ao vapor de $\mathrm{HCl}$ após 2 horas de irradiação implica no aparecimento de uma banda estreita na região de $800 \mathrm{~nm}$, com uma absorbância nessa região maior que a observada em $600 \mathrm{~nm}$. O que se verifica nos filmes LB irradiados é exatamente o contrário, ou seja, uma diminuição da absorbância na região da banda polarônica, quando comparada com a da região desdopada (600 nm). Possivelmente a exposição dos filmes LB aos raios-X acarrete na formação de uma quantidade inexpressiva de portadores de carga, quando comparado com a dopagem por $\mathrm{HCl}$ [97]. A presença desses portadores pode ser verificada através do aumento da absorção e alargamento da banda na região de $800 \mathrm{~nm}$, no espectro de UV-vis $[7,8,98]$. Quando se realiza o procedimento inverso, expondo primeiro o filme LB aos raios-X e depois dopando-o em vapor de $\mathrm{HCl}$, o que se observa é uma gradual diminuição na intensidade de absorção com o aumento do tempo de irradiação. A exposição do filme $\mathrm{LB}$ de $\mathrm{PANi}$ ao $\mathrm{HCl}$ implica na presença de contra-íons, que acabam acarretando na criação de portadores de cargas livres. Durante a exposição 
dos filmes $\mathrm{LB}$ aos raios-X possivelmente há a perda de $\mathrm{HCl}$ por evaporação, ocasionando um decréscimo da intensidade de absorção da banda polarônica.

Verificou-se também o efeito de desdopagem, pela exposição ao vapor de hidróxido de amônio (amônia, $\mathrm{NH}_{3}$ ), em filmes $\mathrm{LB}$ irradiados em atmosfera ambiente a $50 \%$ e a $90 \%$ de umidade. Subseqüentemente, esses filmes foram expostos durante cinco minutos ao vapor de $\mathrm{HCl}$. Os resultados são ilustrados nas Figuras 50 e 51 a seguir.

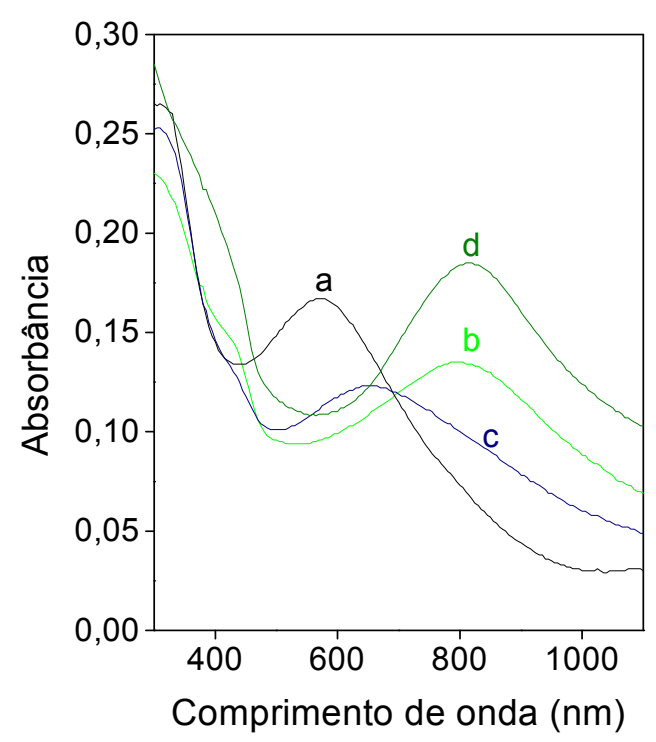

$$
\begin{aligned}
& \text { a - recém depositado } \\
& \text { b - irradiado por } 760 \text { min em } \\
& \text { atmosfera ambiente } \\
& \mathrm{c} \text { - desdopado em amônia por } \\
& \quad 45 \text { min } \\
& \text { d - exposto ao vapor de } \mathrm{HCl} \\
& \quad \text { por } 5 \text { min }
\end{aligned}
$$

FIGURA 50 - Dopagem e desdopagem de um filme LB de PANi, contendo 84 camadas, após 760 minutos de irradiação em atmosfera ambiente a 50\% de umidade.

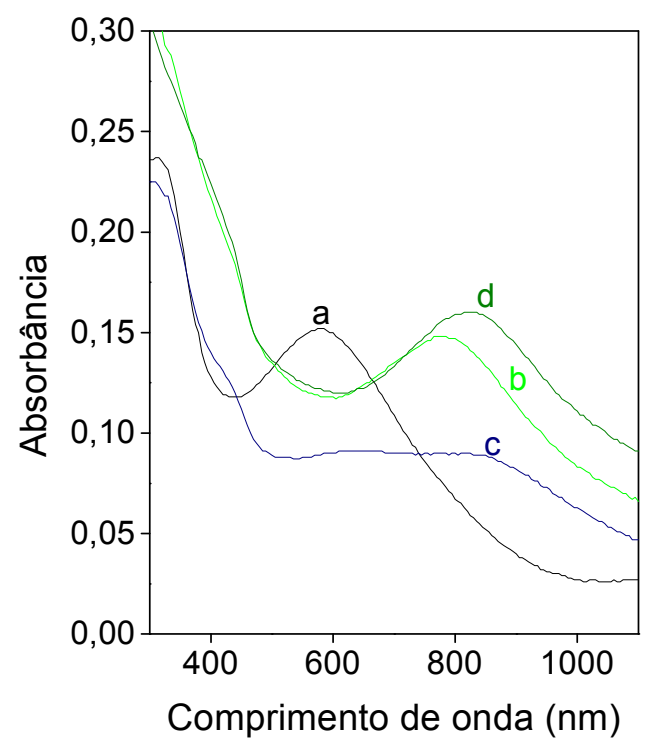

a - recém depositado

b - irradiado por $240 \mathrm{~min}$ a $90 \%$ de umidade

c - desdopado em amônia por $45 \mathrm{~min}$

d - exposto ao vapor de $\mathrm{HCl}$ por $5 \mathrm{~min}$

FIGURA 51 - Dopagem e desdopagem de um filme LB de PANi, contendo 84 camadas, após 240 minutos de irradiação a $90 \%$ de umidade. 
Nos filmes LB de PANi expostos aos raios-X à atmosfera ambiente ( $50 \%$ de umidade), contendo 84 camadas, e posteriormente expostos ao vapor de amônia (Fig. 50), nota-se que há a desdopagem pela presença da banda de absorção na região de $600 \mathrm{~nm}$. Verifica-se dessa forma que a "dopagem” pela exposição dos filmes LB aos raios-X é um processo parcialmente reversível, ao passo que em filmes "casting", a desdopagem é completamente reversível [11]. Com o filme LB contendo o mesmo número de camadas, e irradiado a 90\% de umidade (Fig. 51), verifica-se que ocorre um alargamento da banda, sendo difícil especificar qual o comprimento de onda correspondente ao máximo de absorção. Em ambos os casos, após exposição dos filmes ao vapor de $\mathrm{HCl}$, nota-se novamente o aparecimento da banda polarônica, com o valor de absorbância maior que o observado no caso de exposição dos filmes aos raios-X, e ao observado nos filmes recém depositados, na região de $600 \mathrm{~nm}$. A diferença observada quanto ao processo de desdopagem, pela exposição dos filmes LB a amônia, pode estar relacionada à alta percentagem de umidade na atmosfera de medida, já que este era o único parâmetro variável nessas medidas.

Pela importância dos efeitos do $m$-cresol na polianilina, como o de dopagem secundária, foram realizados alguns experimentos expondo filmes LB de PANi ao vapor desse agente plastificante antes e depois de irradiá-los. Os resultados da exposição dos filmes LB (23 camadas) ao vapor de $m$-cresol por dois dias, e a posterior irradiação em atmosfera ambiente, podem ser observados na Figura 52. A simples exposição dos filmes recém depositados ao vapor de $m$-cresol causa uma diminuição na absorção na região de $560 \mathrm{~nm}$ e um alargamento na banda, concomitantemente com o desvio no pico de absorção para a região de comprimentos de onda maiores. Esse efeito já era esperado uma vez que esse agente plastificante atua como dopante, tanto primário quanto secundário, na polianilina. A subseqüente exposição desses filmes aos raios-X gera o aparecimento do pico na região de 800 nm, e o aumento do tempo de irradiação parece não afetar o pico de absorção nessa região. Ainda nessa figura nota-se a presença de um pico, próximo a $1000 \mathrm{~nm}$, para a curva 52a. Isso é um problema de calibração do equipamento relacionado à linha de base. 


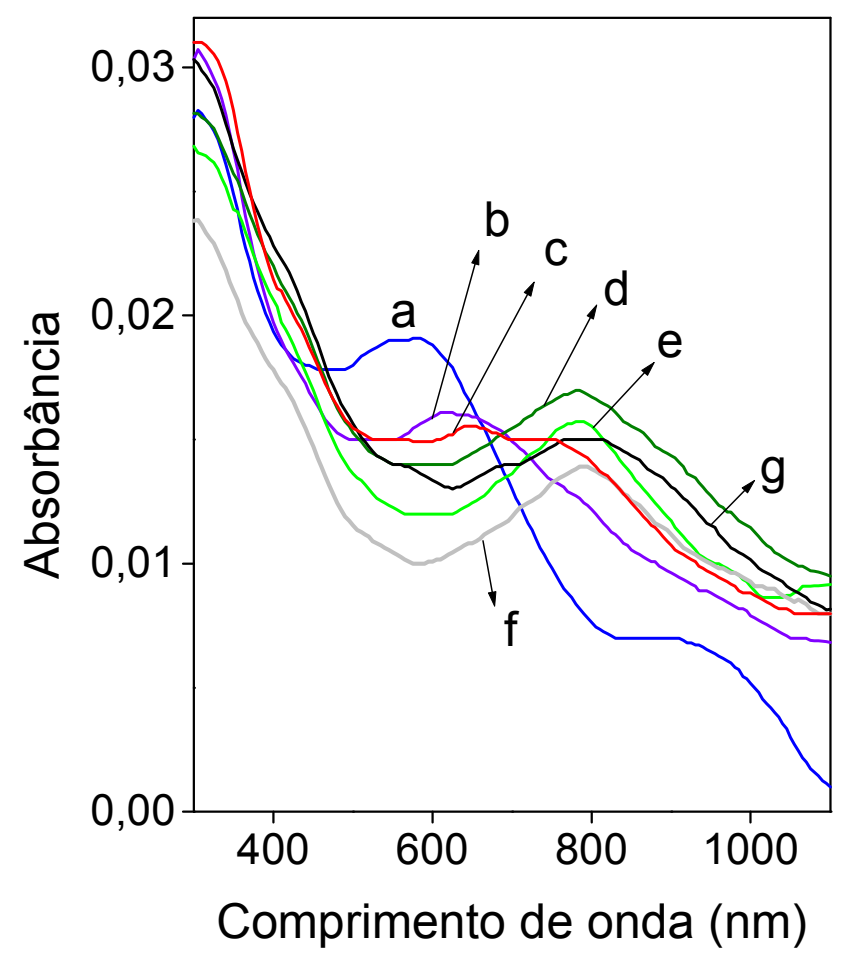

a - recém depositado

b - exposto 1 dia ao vapor de m-cresol

c - exposto 2 dias ao vapor de m-cresol

$\mathrm{d}$ - irradiado por $15 \mathrm{~min}$ em atmosfera ambiente

e - irradiado por $45 \mathrm{~min}$ em atmosfera ambiente

f - irradiado por $105 \mathrm{~min}$ em atmosfera ambiente

g - irradiado por $224 \mathrm{~min}$ em atmosfera ambiente

FIGURA 52 - Espectros UV-vis para um filme LB de PANi, contendo 23 camadas, exposto ao vapor de m-cresol por 2 dias e irradiado durante 224 minutos em atmosfera ambiente a 50\% de umidade.

O caso contrário ao relatado anteriormente, ou seja, expor um filme LB (23 camadas) recém depositado aos raios-X durante cinqüenta minutos, a 90\% de umidade, e posteriormente deixá-lo exposto ao vapor de $m$-cresol por vinte dias, está ilustrado na Figura 53. Nesse caso, após a irradiação, verifica-se que com o aumento do tempo de exposição ao vapor do $m$-cresol há um desvio, com um ligeiro estreitamento da banda de absorção na região de comprimentos de onda maiores. Novamente os efeitos de elevadas percentagens de umidade são observados na Fig. 53. Mencione-se que em ambos os casos de filmes expostos ao vapor de $m$-cresol, antes e depois de irradiá-los, há problemas de linha de base nas medidas de UV-vis, o que pode ser facilmente inspecionado pelo deslocamento de um espectro inteiro (por exemplo curva e na Fig. 53) em relação aos demais. 


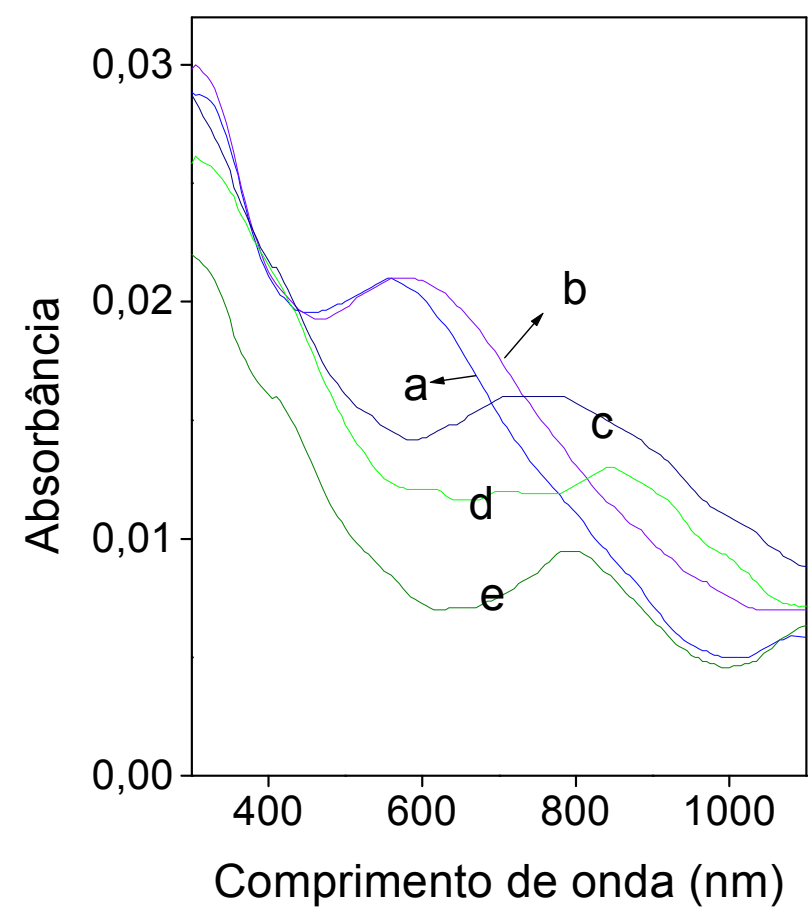

a - recém depositado

b - UV-vis após 24 horas antes de irradiar

c - irradiado por $50 \mathrm{~min}$ ( $90 \%$ de umidade)

$\mathrm{d}$ - exposto ao vapor de $\mathrm{m}$ cresol por 1 dia

e - exposto ao vapor de mcresol por 20 dias

FIGURA 53 - Espectros UV-vis para um filme LB, contendo 23 camadas, irradiado durante 50 minutos a 90\% de umidade e, posteriormente, exposto ao vapor de m-cresol por 2 dias.

Outro fenômeno observado, possivelmente devido à difusão de água na amostra, está ilustrado nas Figuras 54 e 55 a seguir.

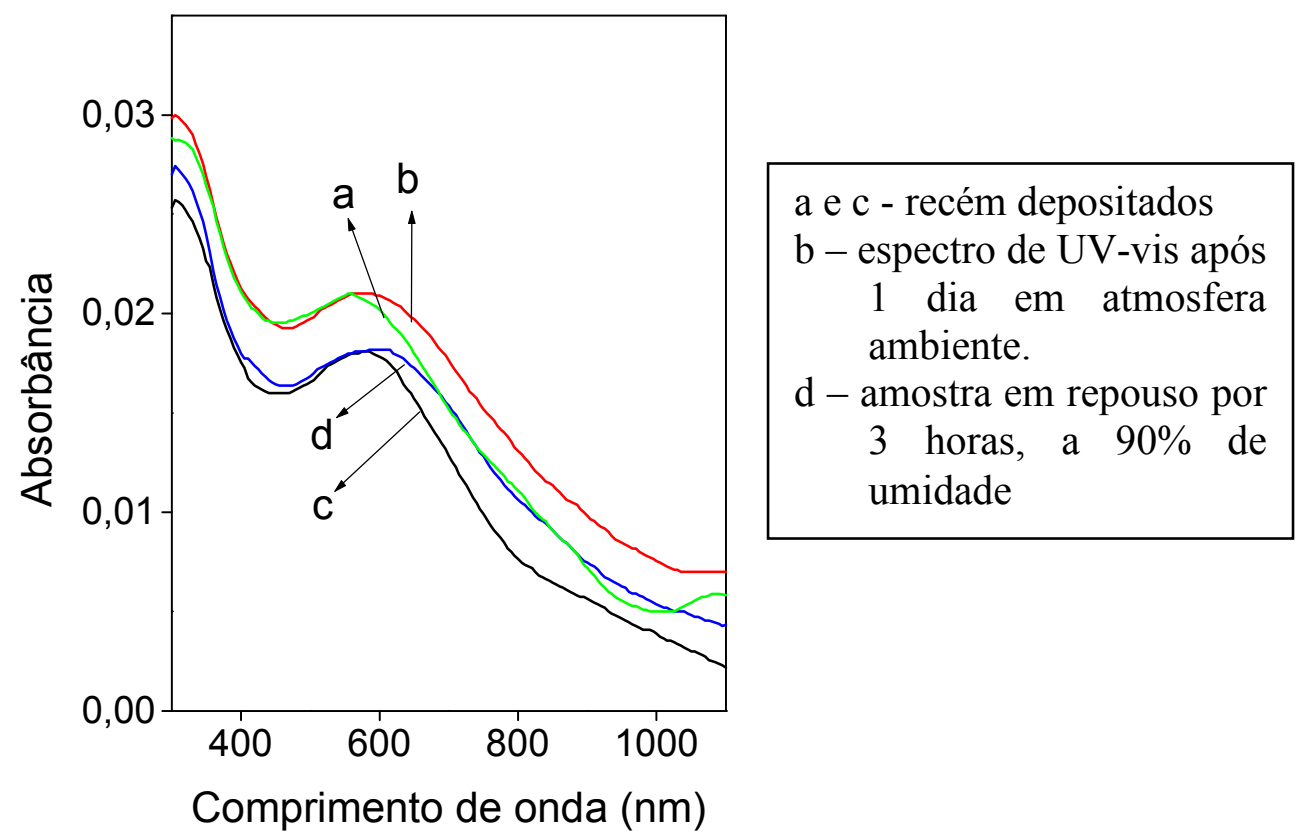

FIGURA 54 - Variações no espectro de UV-vis em filmes LB de PANi contendo 23 camadas, sem irradiação, em diferentes condições de umidade. 


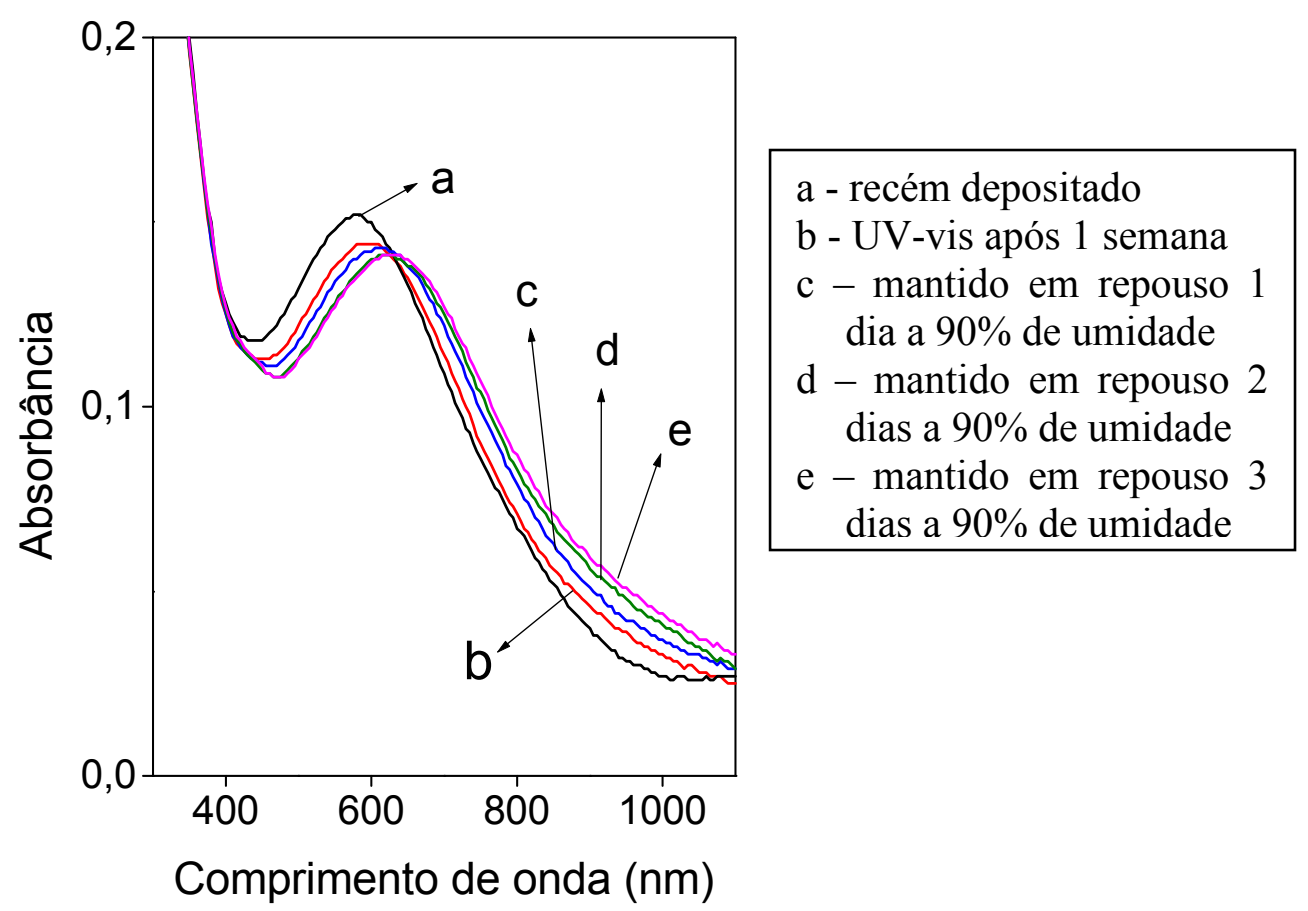

FIGURA 55 - Variações no espectro de UV-vis de um filme LB de PANi contendo 84 camadas, mantido em repouso em atmosfera ambiente a $90 \%$ de umidade.

Nota-se nas Figuras 54 e 55 que há um pequeno desvio no espectro dos filmes recém depositados para a região de comprimentos de onda maiores, sem expôlos aos raios-X, tanto a 90\% de umidade quanto em atmosfera ambiente, após um certo intervalo de tempo. O mesmo fenômeno pode ser observado na Figura 44 (curvas b e c). A diferença é que em atmosferas com elevada percentagem de umidade esse intervalo de tempo diminui. Esse fenômeno é observado em filmes LB de diversas espessuras (comparar as Figuras 54 e 55), e interessantemente há um ligeiro aumento nos valores de absorção na região de comprimentos de onda maiores $(>700 \mathrm{~nm})$, como observado nos resultados anteriores em filmes expostos aos raios$\mathrm{X}$. Caso os filmes sejam previamente irradiados, observa-se ainda o desvio do pico de absorção, como ilustrado na Figura 56. 


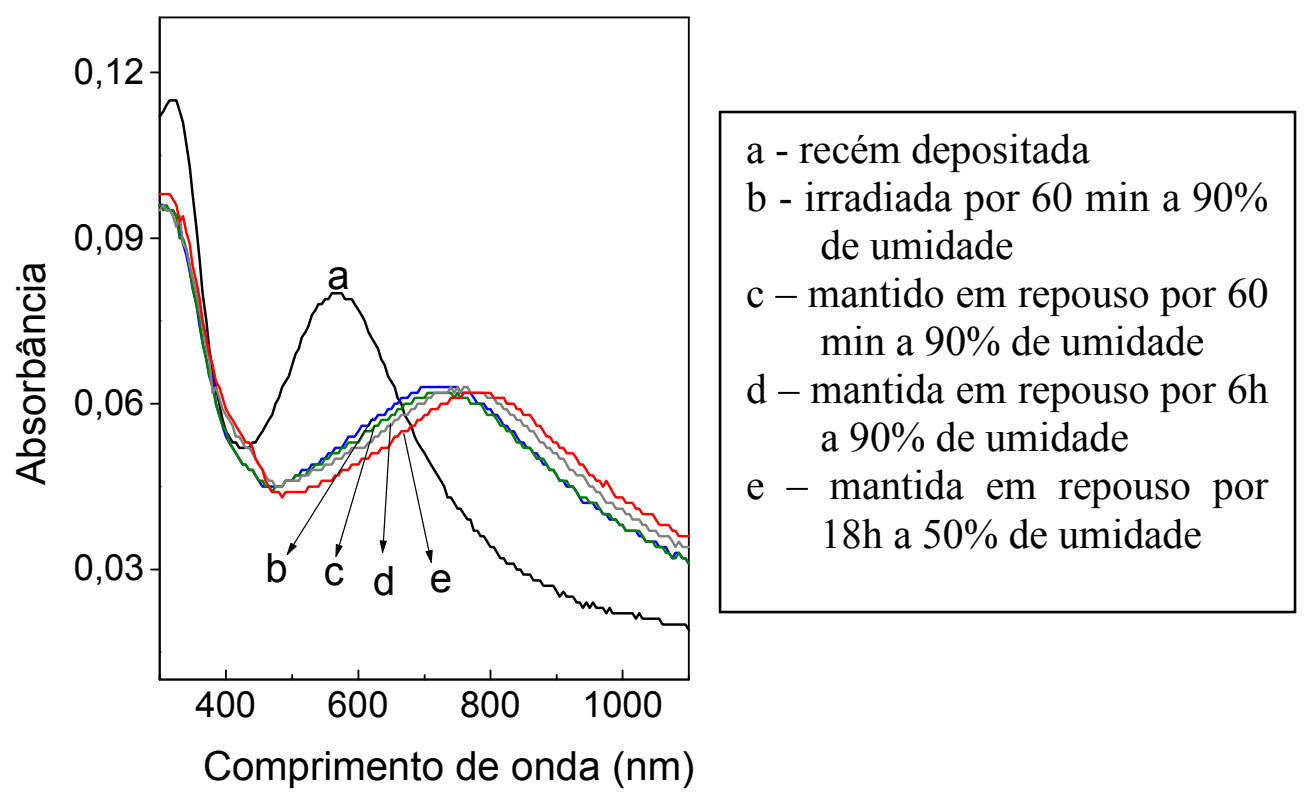

FIGURA 56 - Variação no espectro de UV-vis em um filme LB de PANi contendo 40 camadas, mantida em repouso por dezoito horas em atmosfera a 90\% de umidade, após um hora de irradiação.

A Figura 56 mostra que os espectros UV-vis obtidos após a irradiação da amostra, deixada em repouso em atmosfera ambiente a 90\% de umidade, possuem o mesmo comportamento que o observado nos filmes recém depositados deixados em repouso nas mesmas condições (90\% de umidade), sem prévia exposição aos raios$\mathrm{X}$, como verificado na Fig. 55.

Alterando a atmosfera na qual se encontra o filme LB durante a exposição aos raios-X, verifica-se que esse fenômeno de difusão não é tão intenso quanto os observados nas Figuras 54, 55 e 56. Isso é ilustrado com a comparação com a Figura $44 c$, em que uma amostra foi armazenada em atmosfera ambiente, tendo ocorrido uma alteração menor no espectro do que a que ocorreu para as amostras das Figuras 54,55 e 56, armazenadas em $90 \%$ de umidade.

Com a finalidade de verificar se esse processo de difusão realmente ocorre nos filmes LB, irradiamos inicialmente uma amostra contendo 10 camadas, durante trinta minutos, em atmosfera de argônio. Posteriormente mantivemos o mesmo filme em atmosfera ambiente, a 90\% de umidade, durante uma hora e meia antes de irradiá-lo novamente, só que com uma placa de quartzo de $1 \mathrm{~mm}$ de espessura sobre o mesmo. Os resultados são mostrados na Fig. 57 a seguir. 


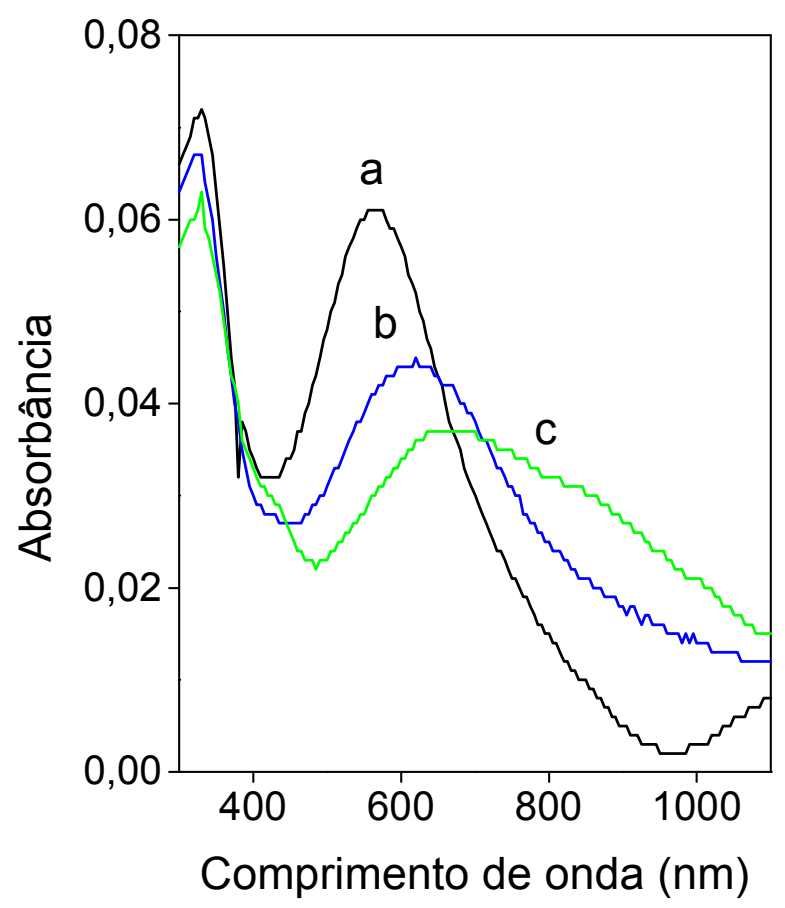

FIGURA 57 - Espectros UV-vis para um filme LB contendo 10 camadas: a) recém depositado; b) irradiado 45 minutos em atmosfera de argônio; c) irradiado 30 minutos em atmosfera ambiente a 90\% de umidade com uma placa de quartzo de $1 \mathrm{~mm}$ de espessura sobre o mesmo.

Como era de se esperar após a irradiação em atmosfera de argônio o filme LB continua apresentando uma banda de absorção em $600 \mathrm{~nm}$. Com a subseqüente irradiação, a 90\% de umidade, observa-se uma diminuição dessa banda de absorção concomitantemente com o desvio para a região de comprimentos de onda maiores. Interessantemente, se compararmos a curva $57 \mathrm{c}$ com a Fig. $45 \mathrm{f}$, vê-se claramente que para o tempo de exposição adotado (30 minutos) esperar-se-ia o aparecimento da banda de absorção em 800 nm, como na Figura 45.

Realizamos ainda dois outros experimentos relacionados a esse possível processo de difusão. Em um deles irradiamos filmes LB contendo 21 camadas em atmosfera ambiente ( $\sim 50 \%$ de umidade). Um dos filmes foi exposto aos raios-X ao ar livre, e o outro foi exposto dentro do tuperware, sem água no seu interior, contendo apenas a amostra. Os resultados são apresentados na Figura 58. No outro experimento colocamos um placa de chumbo de $1,5 \mathrm{~mm}$ de espessura, disposta $8 \mathrm{~mm}$ acima do filme LB, irradiando as amostras (10 camadas) durante quarenta minutos em atmosfera ambiente a $50 \%$ e a $90 \%$ de umidade. A Figura 59 ilustra os resultados. 


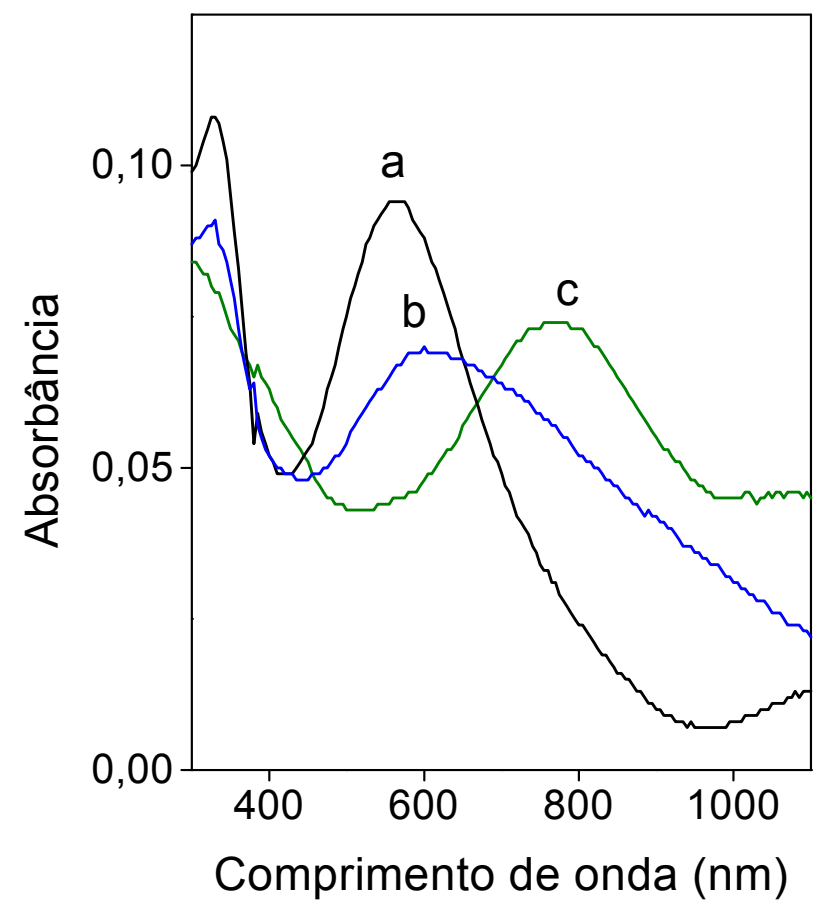

FIGURA 58 - Espectros UV-vis para filmes LB contendo 21 camadas, irradiados durante 40 minutos em atmosfera ambiente ( $\sim 50 \%$ de umidade): a) recém depositado; b) irradiado ao ar livre; c) irradiado dentro do tuperware.

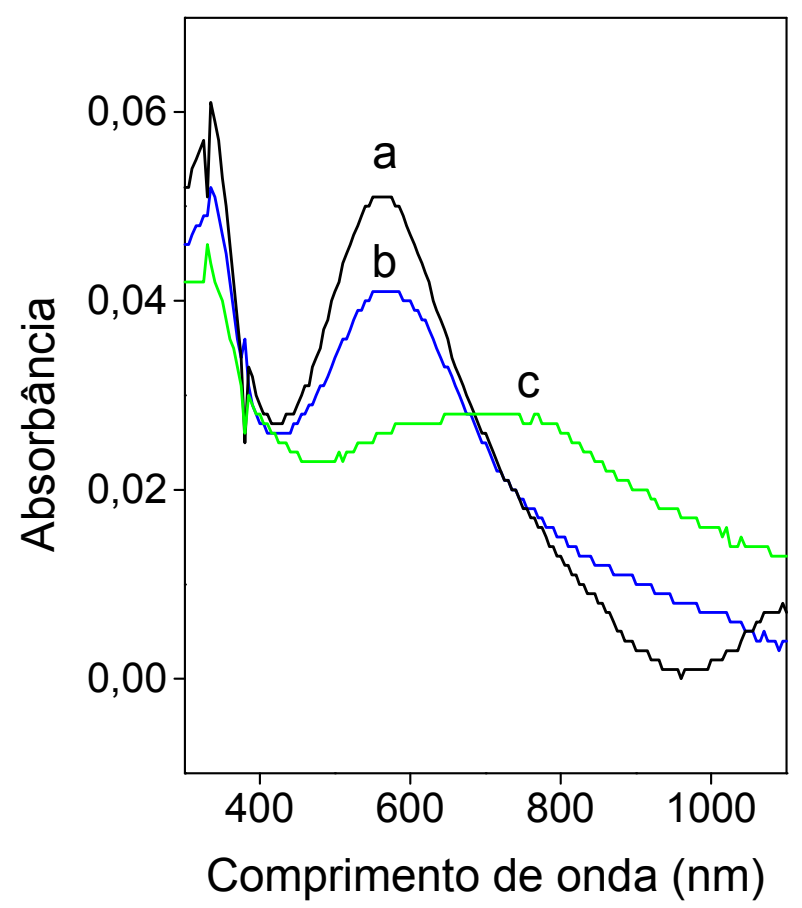

FIGURA 59 - Espectros UV-vis para um filme LB contendo 10 camadas coberto com uma placa de chumbo de 1,5 mm de espessura: a) recém depositado; b) irradiado 40 minutos em atmosfera ambiente a 50\% de umidade; c) irradiado 40 minutos em atmosfera ambiente a $90 \%$ de umidade. 
Observa-se na Fig. 58 que para a amostra irradiada dentro do tuperware fechado, em atmosfera ambiente ( $\sim 50 \%$ de umidade), há o aparecimento da banda de absorção em $800 \mathrm{~nm}$. Comparando esse resultado com aqueles obtidos na Figura 34, verifica-se que, possivelmente, a ionização do ar pode estar gerando algum tipo de espécie que esteja influenciando o processo tanto quanto a presença de água em atmosferas inertes. Quanto à utilização da placa de chumbo, a espessura utilizada é suficiente para impedir a passagem de raios-X. A energia do feixe incidente é de 31 $\mathrm{KeV}$, mas a intensidade ao atravessar a placa de chumbo de 1,5 $\mathrm{mm}$ de espessura é reduzida em $10^{23}$ vezes. Para os cálculos de intensidade utilizamos a relação de absorção $[99,100]$ :

$I=I_{0} \cdot e^{-\mu_{l} \cdot x}$

Na equação 7 acima $I$ é a intensidade do feixe após atravessar o material, $I_{0}$ a intensidade do feixe incidente, $x$ a espessura da placa de chumbo $(1,5 \mathrm{~mm})$, e $\mu_{l} \mathrm{o}$ coeficiente de absorção linear do chumbo. $\mu_{l}$ é a fração de energia que é absorvida por $\mathrm{cm}^{3}$, valendo $363 \mathrm{~cm}^{-1}$ para o chumbo [99,100]. Mesmo assim o fenômeno de transição da banda de absorção para a região de $800 \mathrm{~nm}$ continua existindo, sendo acentuado em atmosferas mais úmidas. Esses resultados serão discutidos na próxima seção.

A condutividade dos filmes LB recém depositados, pelo método de van der Pauw, é da ordem de $10^{-5}{\mathrm{~S} . \mathrm{cm}^{-1}}^{-}$geralmente aumenta em uma ordem de grandeza $\left(\sim 10^{-4}{\left.\mathrm{~S} . \mathrm{cm}^{-1}\right)}\right.$ após a dopagem com $\mathrm{HCl}$. A exposição dos filmes LB aos raios-X, entretanto, parece não alterar a condutividade elétrica, permanecendo em torno de $10^{-5} \mathrm{~S} \mathrm{~cm}^{-1}$. Isso a despeito de os filmes LB terem se tornado verdes após a irradiação, com variações correspondentes no espectro de absorção característico na região do UV-vis. Como mencionado antes, um aumento de dez ordens de grandeza foi observado com os filmes de polianilina obtidos por "casting" sob dopagem por irradiação [11]. Resultados de medidas a.c. em filmes LB expostos aos raios-X serão comentados no capítulo 6 .

\section{4) Possível mecanismo para os efeitos dos raios- $X$}

Antes de propor algum mecanismo para explicar os efeitos da irradiação de filmes LB por raios-X, convém resumirmos os principais resultados: 1) o 
deslocamento das bandas de absorção, característico de dopagem, é favorecido em ambientes úmidos, e o processo é tão mais rápido quanto maior for a umidade relativa; 2) a irradiação em atmosferas de diferentes gases secos também não causa dopagem, embora tenha havido um pequeno efeito para o argônio; 3) quando a superfície do filme é protegida por uma lâmina de quartzo, os efeitos são minimizados; 4) a dopagem é mais rápida para filmes mais finos; 5) surpreendentemente, uma lâmina de chumbo colocada a alguns milímetros do filme, que deveria impedir toda a passagem de raios-X, não eliminou o efeito de dopagem por completo, e em ambiente mais úmido a transição é mais acentuada.

\subsection{1) Efeitos de ionização causados pelos raios-X e a importância da água no processo}

Quando partículas de alta energia atravessam a matéria, elas causam o fenômeno de ionização ao longo do caminho que percorrem. A energia gerada pelo feixe de raios-X $\left(\sim 7.10^{5} \mathrm{Kcal} / \mathrm{mol}\right)$ em nossos experimentos é suficiente para quebrar as moléculas de água (492 Kcal/mol), as ligações de ponte de hidrogênio do tipo NH---N ( 10 Kcal/mol) [101], e ainda ionizar o ar e as espécies químicas utilizadas nas atmosferas dos gases puros, como o argônio, o oxigênio e o nitrogênio. Para o oxigênio são necessárias $749 \mathrm{Kcal} / \mathrm{mol}$, para o nitrogênio 853,6 Kcal/mol, para o argônio $621 \mathrm{Kcal} / \mathrm{mol}$, para o $\mathrm{CO}_{2} 800 \mathrm{Kcal} / \mathrm{mol}$, e para o ar seco $818,8 \mathrm{Kcal} / \mathrm{mol}$ [102-104]. Bay et al [104] consideraram efeitos de recombinação no processo de ionização do ar por raios-X, encontrando um valor de 738,9 Kcal/mol. Para a criação de um par iônico são necessárias 476,8 Kcal/mol.[105].

Outra possibilidade seria a formação indireta de espécies iônicas. As interações entre os fótons de raios-X e as moléculas dos gases da atmosfera (ou mesmo do filme LB) podem produzir elétrons suficientemente energéticos (como elétrons secundários) capazes de ionizar a atmosfera, favorecendo colisões entre pares iônicos e moléculas dos gases, ou mesmo do polímero. Portanto, as excitações não causadas diretamente pelos raios-X, o serão por colisões secundárias, responsáveis pela ionização do ambiente de medida.

Medidas realizadas no ar contendo quantidades variáveis de vapor de água mostram um aumento na ionização quando a proporção de vapor aumenta em relação 
ao ar seco [99]. Possivelmente ocorra uma diminuição na energia necessária para produzir um par de íons no ar devido à presença de vapor de água. Sabe-se ainda que uma gota d'água irá se condensar mais rapidamente sobre um íon carregado do que sobre uma molécula neutra [100]. Desta forma a água passa a ter um papel importante no processo de ionização das moléculas presentes na atmosfera de medida.

\subsection{2) Possibilidade da dopagem direta da polianilina pelos raios- $X$}

Analisaremos agora apenas o caso das interações entre os fótons provenientes da irradiação com o filme polimérico. Consideremos que os raios-X causem a remoção de elétrons dos anéis das unidades amina e imina da PANi, ou das ligações entre os anéis e os átomos de nitrogênio que compõem a cadeia polimérica. Consequentemente teríamos a formação de espécies químicas diferentes, resultantes da degradação do material. Os resultados de FTIR apresentados neste capítulo parecem indicar o contrário. Se por outro lado os elétrons removidos forem aqueles pertencentes às ligações $\pi$, haverá a formação de uma forma não estável do polímero à procura de espécies químicas que restabeleçam o equilíbrio químico da cadeia, ou até de radicais livres que pudessem de alguma forma dopar o polímero. Não acreditamos que a formação de radicais no material seja um processo dominante nesse mecanismo de dopagem, tendo em vista os resultados apresentados de irradiação com uma placa de chumbo disposta $8 \mathrm{~mm}$ acima da superfície dos filmes LB, embora não possa ser completamente descartado nos casos de irradiação sem a presença de um anteparo. Entretanto, no caso da placa de chumbo, temos que descartar a suposição do aparecimento de uma forma instável da polianilina devido a remoção de elétrons pelos raios-X.

\subsection{3) Influência da água nas propriedades elétricas da polianilina}

A absorção de água na PANi é um processo volumétrico diretamente relacionado aos prótons que dopam o polímero [89]. Estudos termogravimétricos e de calorimetria diferencial de varredura realizados com polianilina sintetizada quimicamente [90,91] sugerem que as moléculas de água formam pontes de hidrogênio com os centros ácidos da polianilina, e que possivelmente existam duas 
formas de adsorção para as moléculas de água na matriz polimérica. Uma mais fracamente ligada aos nitrogênios amina com uma energia de ativação de 3 a 5 $\mathrm{Kcal} / \mathrm{mol}$, chamada aqui de água1, que pode ser facilmente removida com fluxo de nitrogênio. A outra, denominada de água2, mais fortemente ligada à cadeia polimérica nos nitrogênios imina, com uma energia de ativação de 15 a $18 \mathrm{Kcal} / \mathrm{mol}$, cuja retirada pode ser feita apenas em elevadas temperaturas, o que implica na decomposição da polianilina [90,91]. As moléculas de água estariam ligadas ao polímero através de pontes de hidrogênio, que acabariam provocando variações na conformação molecular das cadeias poliméricas. A protonação causada pela presença de água nos átomos de nitrogênio resulta na formação de um policátion positivamente carregado $\left(-\mathrm{N}^{+} \mathrm{H}=\right)$, estabilizado entre a deslocalização $\pi$ ao longo da cadeia polimérica. Entretanto, a força ácida da água não é forte o suficiente para converter a forma base em um sal, mas mesmo assim estimula o processo de protonação e gera um aumento na condutividade elétrica da PANi [90,91]. A diferença entre os valores de condutividade elétrica das amostras secas e hidratadas foram de três ordens de grandeza, e a mobilidade dos portadores de carga depende fortemente da densidade de moléculas de água adsorvidas nas unidades repetitivas do polímero [91]. Pelos resultados apresentados na Fig. 57 verificamos que o processo de absorção de água pelo polímero é relevante para a dopagem por raios-X. Como o tempo de irradiação utilizado é mais do que suficiente para dopar a amostra a $90 \%$ de umidade, e sabendo-se ainda que a placa de quartzo diminui a intensidade do feixe apenas de $20 \%$, a única explicação plausível deve estar relacionada a um impedimento nesse processo de absorção causado pela lâmina de quartzo.

\subsection{4) Hipóteses sobre a dopagem da PANi através dos raios- $X$}

Com base nos resultados apresentados neste capítulo, é mais provável que os efeitos no filme LB sejam devidos à ionização da atmosfera, sempre requerendo a presença de água. O produto dessas ionizações seria o responsável pela dopagem da PANi. De fato, a irradiação dos filmes LB revelou que as variações observadas no espectro de UV-vis são atingidas mais rapidamente em atmosferas com níveis de umidade mais elevados. O deslocamento não aparece em filmes LB irradiados em atmosferas de oxigênio, nitrogênio, argônio e no vácuo $\left(\sim 10^{-4}\right.$ Torr $)$. A possibilidade 
de interação direta entre os raios-X e as moléculas de PANi, embora não possa ser inteiramente descartada, parece menos provável, principalmente após os resultados das medidas realizadas em vácuo (Fig.40), confirmadas posteriormente com as do anteparo de chumbo (Fig. 59).

Acreditamos que na presença de água o processo de recombinação das espécies formadas não seja favorecido devido à preferência de condensação das moléculas de água sobre íons carregados, permitindo a formação de diferentes espécies químicas, ou até mesmo íons "solvatados" por moléculas de água, que dependendo de sua natureza tenderiam a interagir com o polímero. Como o processo de absorção de água pela PANi é um processo volumétrico, a incorporação de água na amostra acabaria introduzindo algumas dessas espécies (ou íons) geradas pela ionização do feixe de raios-X, como suposto acima, no volume da amostra. Essas espécies, por sua vez, acabariam interagindo com as cadeias poliméricas estimulando o processo de protonação. Pode estar aqui o princípio da dependência da dopagem com a espessura dos filmes, como ilustrado na Figura 48. Resultados obtidos por Malmonge $^{2}$ em filmes de polianilina auto sustentáveis indicaram que em amostras suspensas e irradiadas em ambientes bem úmidos, ambas as faces do filme apresentaram coloração esverdeada, característica do estado condutor (dopado). Deixando a amostra em repouso sobre uma placa de petri nas mesmas condições de irradiação que a amostra suspensa, verificou-se que apenas o lado exposto ao ar úmido apresentava coloração esverdeada, enquanto a face em contato com a placa de petri mantinha coloração azulada.

Deve ser notado que os tempos envolvidos são muito maiores do que aqueles esperados para haver equilíbrio na difusão de um ácido no filme, pois é possível dopar completamente um filme mais espesso que um filme LB em um tempo muito menor (alguns minutos), se o filme for exposto ao vapor ou ácido em solução. O tempo característico para a difusão da água também não deve ser tão longo, como os tempos requeridos para a dopagem por raios-X. Ou seja, o processo de difusão da água deveria se completar em alguns minutos e nenhum efeito da espessura seria observado, ao contrário do que ocorreu. Todavia, se considerarmos novamente que as moléculas de água possam "arrastar" espécies para o interior do material,

\footnotetext{
${ }^{2}$ J.A. Malmonge, comunicação pessoal, resultados não publicados.
} 
consequentemente o tempo necessário para esse processo deve ser maior, como o observado aqui.

Outra possibilidade de interação direta dos raios-X, ou de radiações secundárias, com o polímero, é que durante a irradiação algumas moléculas de água1 possam estar sendo quebradas, causando a protonação da PANi. Não consideramos a quebra de água2 uma vez que sua retirada estaria relacionada com a degradação do polímero, fato não observado aqui.

Desta forma, concluímos que a dopagem de filmes LB mistos de polianilina com estearato de cádmio deve-se a dois processos principais:

i) a ionização da atmosfera do ambiente de medida, que leva à formação de espécies ácidas iônicas que são estabilizadas pela presença de água;

ii) interação dos raios- $\mathrm{X}$ e de radiações secundárias geradas pela interação com a matéria, que provocam a quebra de moléculas de água presentes na matriz polimérica, o que acabaria estimulando o processo de dopagem da PANi.

Se a suposição (i) for verdadeira, pode-se explicar porque o comportamento em atmosfera de argônio difere daquele observado nos outros gases. Como o argônio tem um potencial de ionização mais baixo que o do oxigênio, nitrogênio e ar seco, o processo de ionização seria favorecido, uma vez que a energia utilizada foi a mesma para permitir que os íons ou as espécies químicas formadas pudessem interagir em um intervalo de tempo menor que o requerido para os outros gases, implicando assim numa transição mais rápida da banda de absorção para a região de comprimentos de onda maiores.

\subsection{5) Comparação com dopagem por corona}

O processo controlado pela incorporação de água na amostra pode ser devido à difusão de espécies (íons) formadas na superfície, à semelhança do que ocorre na descarga corona sobre polímeros [106]. Os resultados de Raposo et al $[106,107]$ indicam que a atmosfera de medida influencia fortemente os resultados, e ainda há a criação de uma camada líquida sobre a superfície da amostra devido à presença de vapor de água na atmosfera de medida. Aqui é interessante ressaltar que a corona positiva é mais eficiente do que a negativa, o que demonstra a importância das espécies químicas formadas na superfície [106]. De fato, a dopagem de PANi por 
descarga corona também foi observada, como relatado por Job et al [108], para filmes compósitos de PET cobertos com polianilna, e mais recentemente para filmes LB de PANI. Pela comparação dos resultados, acreditamos que os processos de dopagem da polianilina pela descarga corona e pelos raios-X envolvam mecanismos distintos, já que as energias envolvidas e as espécies químicas formadas são diferentes.

\section{5) Conclusões}

A exposição de filmes LB de polianilina com CdSt aos raios-X leva a uma variação sistemática e contínua nos espectros de UV-vis. Após um determinado tempo de irradiação há o aparecimento da banda de absorção polarônica na região de $800 \mathrm{~nm}$, permanecendo inalterável após um tempo prolongado de exposição. As variações no espectro de FTIR devido à irradiação são similares àquelas observadas devido à dopagem da polianilina através de ácidos. Quando comparada com esta última, duas grandes diferenças foram observadas para os filmes LB expostos à radiação: i) a ordem de empacotamento dos domínios de estearato de cádmio não é afetada, como observado nos espectros de difração de raios-X, e ii) nenhum aumento nos valores de condutividade elétrica foi verificado após a exposição dos filmes LB aos raios-X (van der Pauw), enquanto que ao serem dopados quimicamente há um aumento de pelo menos uma ordem de grandeza nos valores de $\sigma$ (van der Pauw). Estas diferenças podem ser explicadas considerando-se que a contribuição interdomínios da condutividade elétrica é aumentada pela dopagem química devido à destruição dos domínios de estearato de cádmio, o que não ocorre com a dopagem por exposição aos raios-X.

A umidade relativa da atmosfera de medida afeta significativamente o tempo em que ocorre o aparecimento da banda de absorção no espectro de UV-vis na região de grandes comprimentos de onda $(\sim 800 \mathrm{~nm})$. Experimentos realizados em filmes LB contendo o mesmo número de camadas, em atmosfera de oxigênio, nitrogênio, argônio e no vácuo, confirmaram a forte influência da umidade nesse tipo de medida. Outro aspecto importante foi a dependência linear dessa transição no espectro de UV-vis para a região de $800 \mathrm{~nm}$ com a espessura do filme LB. Tal fato não era esperado na exposição de filmes ultrafinos à radiação ionizante dos raios-X. 
A desdopagem em vapor de amônia dos filmes LB irradiados é um processo parcialmente reversível, quando comparado com o processo que ocorre com ácidos inorgânicos. A exposição dos filmes LB a ambientes muito úmidos, antes e após a exposição aos raios- $X$, leva a um pequeno deslocamento $(\sim 10 \mathrm{~nm})$ nos espectros de UV-vis, provavelmente devido à difusão de água na amostra.

Filmes LB expostos ao vapor de $\mathrm{HCl}$ e posteriormente irradiados em atmosfera ambiente, e a $90 \%$ de umidade, apresentaram um decréscimo no valor máximo de absorção. Possivelmente a exposição aos raios-X de filmes LB dopados em $\mathrm{HCl}$ favoreça a evaporação do $\mathrm{HCl}$, implicando numa diminuição de portadores de carga.

A dopagem nesse processo de irradiação deve-se principalmente a dois processos. Um deles gerado pela ionização dos gases da atmosfera de medida com a formação de espécies ácidas iônicas, que acreditamos ser estabilizadas pela presença de água. $\mathrm{O}$ outro seria a quebra de algumas moléculas de água presentes no interior do polímero, alterando as propriedades elétricas da PANi através de mudanças nas suas estruturas física e química [90,91]. 


\section{CAPÍTULO 6}

\section{6) Condutividade Elétrica em filmes $L B$ de polianilinas}

\section{1) Introdução}

Existem vários métodos experimentais para medir a condutividade elétrica $(\sigma)$ de um material. Nessa seção será feita uma breve apresentação de alguns desses métodos, conjuntamente com a discussão dos resultados obtidos através de dois deles. Várias questões precisam ser atacadas no que concerne à condutividade elétrica de filmes LB de PANi. Apresentaremos algumas delas e em alguns casos faremos uma discussão das principais dificuldades experimentais encontradas.

Os erros introduzidos nas medidas de condutividade elétrica de um material são provenientes de efeitos termoelétricos e de contato, que podem ser reduzidos através de experimentos que utilizam medidas de corrente alternada, ou baixas voltagens. Costuma-se aplicar diferenças de potencial de baixa magnitude para evitar efeitos não ôhmicos em medidas de corrente alternada (a.c.). Existem ainda outras perturbações, que acabam introduzindo erros nas medidas de condutividade elétrica. Podem ser citadas, por exemplo, a fotoinjeção de cargas da radiação ambiente, induzindo potenciais, particularmente em circuitos que utilizam pontas para as medidas de potencial, provenientes de fontes adjacentes de alta freqüência, e vibrações mecânicas que podem causar a modulação da interferência na ponta de contato para a medida de resistência [109]. Particularmente nas medidas de condutividade elétrica nos filmes LB de PANi existe ainda o problema de fixação dos contatos elétricos que é feita com tinta prata. O solvente da tinta prata (acetato de amila) pode, pelo menos na região dos contatos, interagir com o polímero, desdopando-o. Outros tipos de interação podem ocorrer, mas o efeito global do solvente nas medidas de condutividade elétrica não é conhecido em detalhe.

Um dos métodos mais simples de medidas de $\sigma$ é o método de dois pontos, ou método de medida de condutividade de volume, no qual uma voltagem $(V)$ é aplicada na amostra, a partir de uma fonte de tensão, e a corrente que flui pelo 
volume do material ( $i$ ), entre as duas pontas de contato, é medida por um amperímetro. A Figura 60 ilustra esse método de medida. As partes amarelas na Fig. 60 referem-se a camadas de ouro depositadas sobre a lâmina (faixa estreita) e sobre o filme LB (círculo) para fixação dos contatos elétricos (fios de ouro).
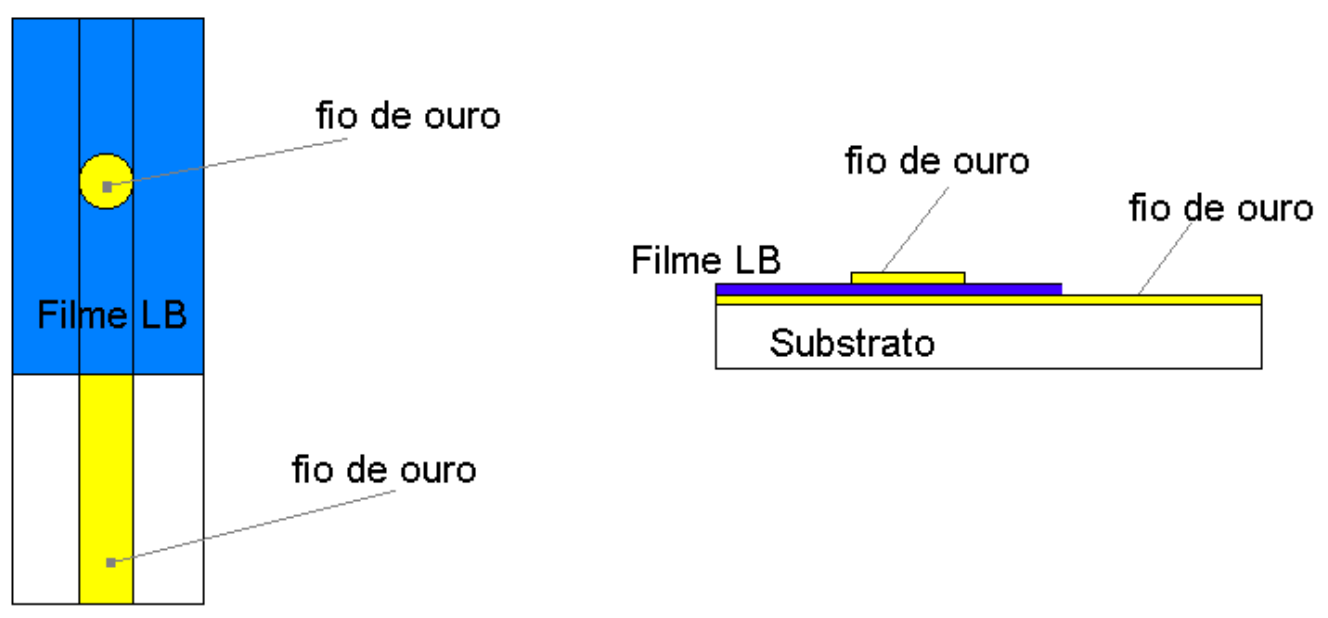

FIGURA 60 - Representação esquemática do método de medida de condutividade elétrica utilizando dois pontos de contato.

Considerando uma amostra uniforme, homogênea e isotrópica, a condutividade elétrica é dada pela expressão:

$\sigma=\frac{i}{V} \cdot \frac{d}{\pi \cdot r^{2}}$

Nessa relação $i$ é a corrente medida, $V$ a diferença de potencial aplicada, $d$ a espessura do filme e $\left(\pi \cdot r^{2}\right)$ a área de contato do eletrodo superior, depositado sobre o filme LB.

Apesar da simplicidade do arranjo experimental e, principalmente, pela vantagem de possibilitar medidas da condutividade volumétrica do material, a não uniformidade das amostras obtidas em subfases ácidas, e a própria difusão do metal utilizado para a confecção do eletrodo superior de contato, no nosso caso o ouro, aumentam os erros das medidas. A restrição sobre a forma da amostra, para fornecer uma distribuição simples de planos equipotenciais e linhas de corrente, acaba sendo a principal desvantagem experimental deste método [109].

$\mathrm{O}$ arranjo colinear de quatro pontas suplanta a desvantagem do formato da amostra no método de dois pontos e permite ainda a medida da condutividade 
elétrica de materiais possuindo uma grande variedade de formas, incluindo aquelas com contornos irregulares, medindo também a condutividade de pequenas regiões em uma matriz com diferentes propriedades elétricas [109], embora a condutividade elétrica obtida passa a ser superficial e não mais volumétrica. $\mathrm{O}$ arranjo experimental é ilustrado na Figura 61.

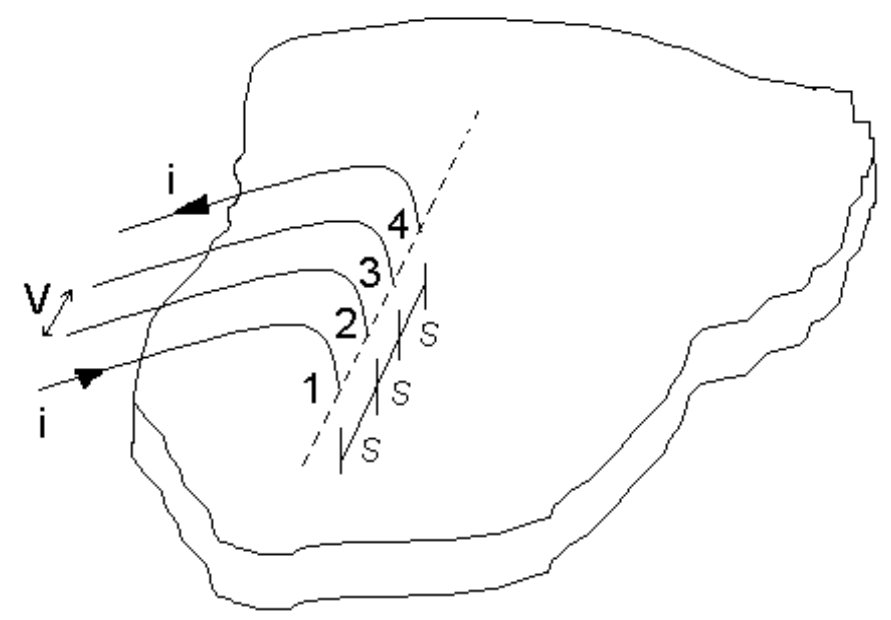

FIGURA 61 - Representação esquemática do método de medida de condutividade elétrica através de quatro pontas colineares.

As pontas externas 1 e 4 estão relacionadas à corrente aplicada no material, enquanto as pontas internas 2 e 3 são utilizadas para medir a diferença de potencial gerada pelo fluxo de corrente na superfície da amostra. Nesse arranjo experimental as quatro pontas estão eqüidistantes e espera-se que elas estejam afastadas o suficiente das extremidades da amostra de forma a considerar uma área uniforme e de resistividade infinita. Outras restrições são necessárias, tais como: i) o diâmetro do contato entre cada ponta e a superfície do material deve ser pequeno quando comparado com a distância $S$ de separação das pontas; ii) a superfície da amostra deve ter uma alta taxa de recombinação de forma que qualquer elétron ou buraco injetado por uma das pontas possa se recombinar rapidamente nas vizinhanças imediatas do contato, não afetando de forma significativa as medidas de condutividade e, iii) a fronteira entre os eletrodos de corrente e o volume do material deve ser pequena em diâmetro e hemisférica em forma [109]. Para um material cuja espessura $d \gg S$, a condutividade elétrica é expressa por:

$\sigma=\frac{i}{V} \cdot \frac{1}{2 \pi S}$ 
Caso $S>>d$ a amostra é considerada como sendo uma folha infinita de espessura infinitesimal, e, desde que a lei de Ohm seja válida, e as linhas de corrente tenham simetria radial, a condutividade passa a ser dada por:

$\sigma=\frac{i}{V} \cdot \frac{\ln 2}{\pi \cdot d}$

Existem fatores de correção que relacionam os parâmetros geométricos de amostras muito finas com a distância de separação das pontas, permitindo medidas mais acuradas de condutividade elétrica [109,110].

Existe ainda o arranjo de quatro pontas eqüidistantes, mas não colinearmente dispostas, como ilustrado na Figura 62.

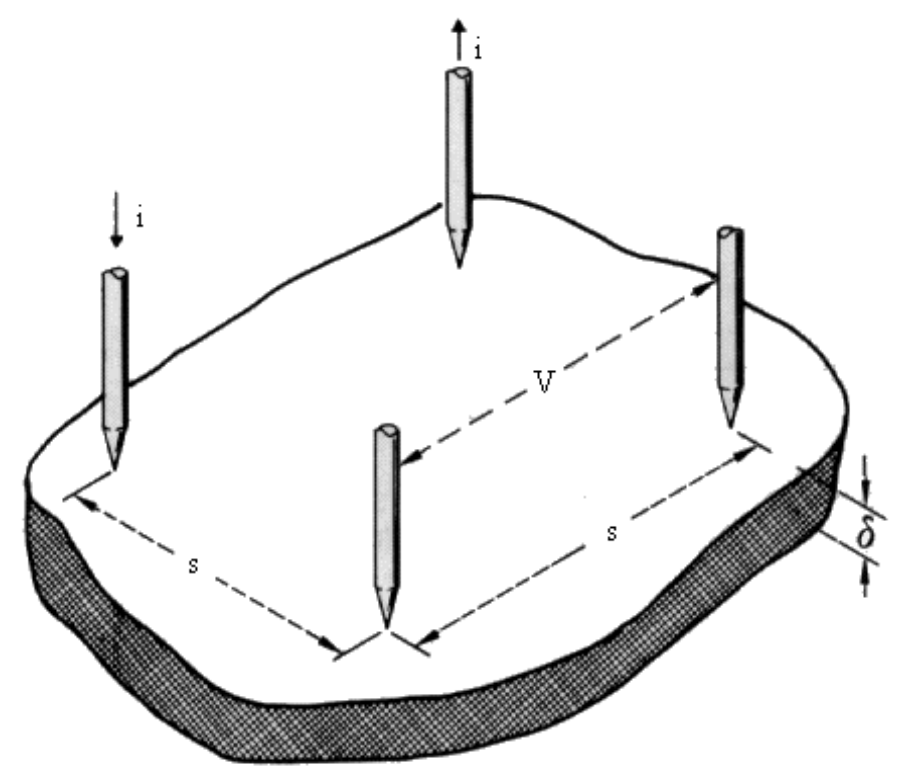

FIGURA 62 - Representação esquemática do método de medidas de quatro pontas eqüidistantes, mas não colineares.

Esse arranjo possui a vantagem de medir a condutividade em amostras com áreas menores que as utilizadas no arranjo de quatro pontas colineares. No caso de uma amostra condutora semi infinita, na qual $d<<S$, a condutividade é dada por:

$\sigma=\frac{\ln 2}{2 . \pi \cdot d .} \frac{i}{V}$

Também nesse caso existem fatores de correção geométrica que tentam minimizar os erros inerentes a essas medidas [109,111]. É interessante notar que os erros atribuídos a esse arranjo são quatro vezes menores do que no arranjo colinear [109]. 
Freqüentemente as medidas experimentais necessitam ser realizadas em amostras de forma e espessura arbitrárias, com os quatro contatos dispostos sobre sua superfície não necessariamente eqüidistantes uns dos outros. O fundamento teórico desse tipo de medida está baseado em tratamentos matemáticos (mapeamento conformacional) que levam em conta se a amostra é uniforme em espessura e isotrópica, e que os contatos sejam ôhmicos [109,112]. O primeiro a desenvolver esses cálculos para a medida de condutividade elétrica foi L.J. van der Pauw. O arranjo experimental está esquematizado na Figura 63 e proporciona algumas vantagens sobre os anteriores. A principal delas é que a técnica desenvolvida por van der Pauw acaba generalizando o princípio de medida de condutividade para uma amostra qualquer, sem restrição geométrica quanto a sua forma e também sem muitas restrições quanto à disposição dos contatos elétricos. Nos casos anteriores são necessários alguns fatores de correção, que levam em conta a geometria da amostra, e ainda a razão entre a distância entre os contatos e a espessura do material, no caso de filmes muito finos.

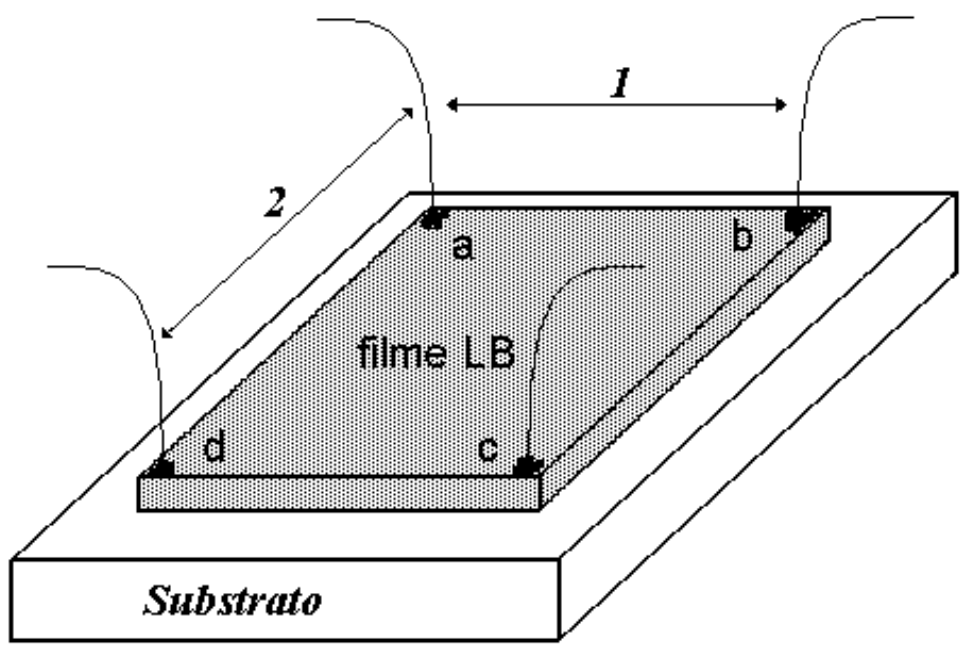

FIGURA 63 - Representação esquemática das medidas de condutividade elétrica utilizando o método de van de Pauw.

No caminho 1 da Fig. 63 aplica-se corrente nos pontos ab $\left(\mathrm{I}_{1}\right)$ e mede-se a voltagem entre os pontos cd $\left(\mathrm{V}_{1}\right)$. No caminho 2 aplica-se corrente em bc $\left(\mathrm{I}_{2}\right)$, medindo a voltagem entre ad $\left(\mathrm{V}_{2}\right)$. A condutividade elétrica pode ser calculada a partir da relação: 
$\sigma=\frac{\ln 2}{\pi \cdot d} \cdot \frac{2}{R_{1}+R_{2}} \cdot \frac{1}{f}$

na qual $d$ é a espessura do filme, e $f$ uma função da razão entre $\mathrm{R}_{1}$ e $\mathrm{R}_{2}$. $\mathrm{R}_{1}$ é definido como a razão $\left(\mathrm{V}_{1} / \mathrm{I}_{1}\right)$, e $\mathrm{R}_{2}$ como a razão entre $\left(\mathrm{V}_{2} / \mathrm{I}_{2}\right)$. A função $f$ pode ser expandida na forma abaixo se os valores de $\mathrm{R}_{1}$ e $\mathrm{R}_{2}$ forem aproximadamente iguais [109]:

$f \cong 1-\left(\frac{R_{1}-R_{2}}{R_{1}+R_{2}}\right)^{2} \cdot \frac{\ln 2}{2}-\left(\frac{R_{1}-R_{2}}{R_{1}+R_{2}}\right)^{4} \cdot\left(\frac{(\ln 2)^{2}}{4}-\frac{(\ln 2)^{3}}{12}\right)$

Pela simplicidade experimental no que concerne à disposição dos contatos na amostra, optamos pela técnica de van der Pauw para as medidas de condutividade elétrica nos filmes LB de PANi e 16-mero. Utilizamos um programa desenvolvido por um colega (Gustavo D. Telles), especificamente para realizar todos os cálculos envolvidos. São fornecidos apenas os valores de corrente $\left(I_{1}\right.$ e $\left.I_{2}\right)$, voltagem $\left(V_{1}\right.$ e $\left.V_{2}\right)$ e a espessura da amostra $(d)$, estimada pelo número de camadas depositadas. A condutividade elétrica foi medida em dois caminhos diferentes ( 1 e 2) com o intuito de verificar se há algum tipo preferencial de orientação nos filmes LB fabricados que pudessem favorecer a condutividade numa determinada direção. $\sigma_{1}$ é a condutividade medida ao longo do caminho 1 e $\sigma_{2}$ a condutividade ao longo do caminho 2 . Ressaltamos aqui que em alguns casos foi utilizada a técnica de dois pontos com o objetivo de verificar o valor da condutividade volumétrica das amostras.

Outra técnica que tem se mostrado muito eficiente na análise dos mecanismos de condução elétrica, iônica e eletrônica em diferentes tipos de materiais, tais como polímeros, semicondutores, cerâmicas e materiais vítreos é a medida de condutividade a.c.. Geralmente as medidas experimentais utilizando essa técnica são realizadas na faixa de freqüência entre $10^{-2}$ a $10^{6} \mathrm{~Hz}$. Surgiram inúmeros trabalhos envolvendo modelos teóricos e programas que permitissem inferir valores de condutividade elétrica, analisando os processos de transporte dos portadores de carga envolvido [113]. Não é nossa intenção uma análise profunda dos mecanismos de transportes em medidas a.c de condutividade elétrica, mas sim verificar por meio de um novo sistema de medida os valores de condutividade elétrica em filmes LB de polianilinas obtidos por meio da técnica de van der Pauw e dois pontos.

O comportamento observado experimentalmente em materiais desordenados da condutividade a.c. é ilustrado na Figura 64. 


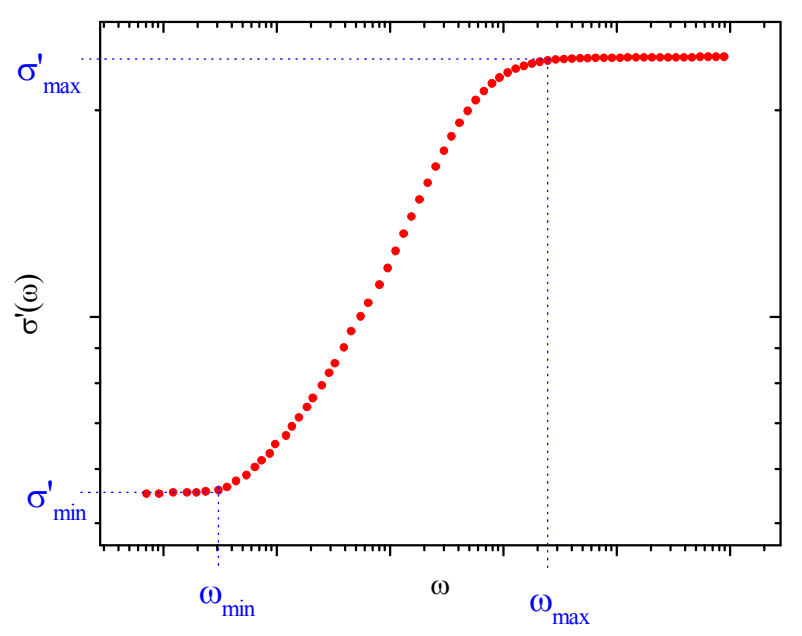

FIGURA 64 - Representação esquemática do comportamento para a condutividade a.c. em materiais desordenados.

Em valores muito altos de freqüência a condutividade a.c. tende a um patamar superior, e em freqüências muito baixas a um patamar inferior. A diferença entre esses patamares tende a diminuir no caso de materiais condutivos, e nesse caso a componente real da condutividade complexa $\left(\sigma^{\prime}(\omega)\right)$ independe da freqüência aplicada $(\omega)$ [113]. O valor da intersecção entre o patamar inferior e o eixo da condutividade fornece o valor equivalente da condutividade d.c., que tende a diminuir no caso de materiais resistivos.

\section{2) Experimental}

Foram utilizados como contato fios de ouro de $0,25 \mathrm{~mm}$ de diâmetro, presos às lâminas, contendo os filmes $\mathrm{LB}$, com tinta prata. Os contatos foram fixados o mais distante possível uns dos outros. Nas medidas d.c. (dois pontos e van der Pauw) utilizou-se ainda uma blindagem contra campos externos através de uma pequena caixa acrílica revestida com papel alumínio, na qual foi aterrado o multímetro Keithley, modelo 637, e a fonte de corrente, também da Keithley, modelo 224. As medidas são delicadas e por isso os procedimentos experimentais precisam ser sistemáticos. Sendo assim, foi fixado um intervalo de tempo de três minutos entre uma medida e outra para que os valores de corrente e tensão pudessem ser anotados.

No caso das medidas a.c. a técnica experimental [113] utilizada permite medir as componentes real $\left(\sigma^{\prime}(\omega)\right)$ e imaginária $\left(\sigma^{\prime \prime}(\omega)\right)$ da condutividade em função 
da freqüência $(\omega)$. Ela consiste basicamente na utilização de uma ponte de impedância, a qual aplica uma tensão alternada com a freqüência variável. Em uma amostra plana na qual é evaporado alumínio para formação de contatos elétricos, são fixados os fios para as medidas (observar a Figura 65). Nessas medidas a.c. de $\sigma$ os contatos foram colocados fora da região na qual encontra-se o filme LB com a finalidade de evitar a difusão do solvente da tinta prata no filme.
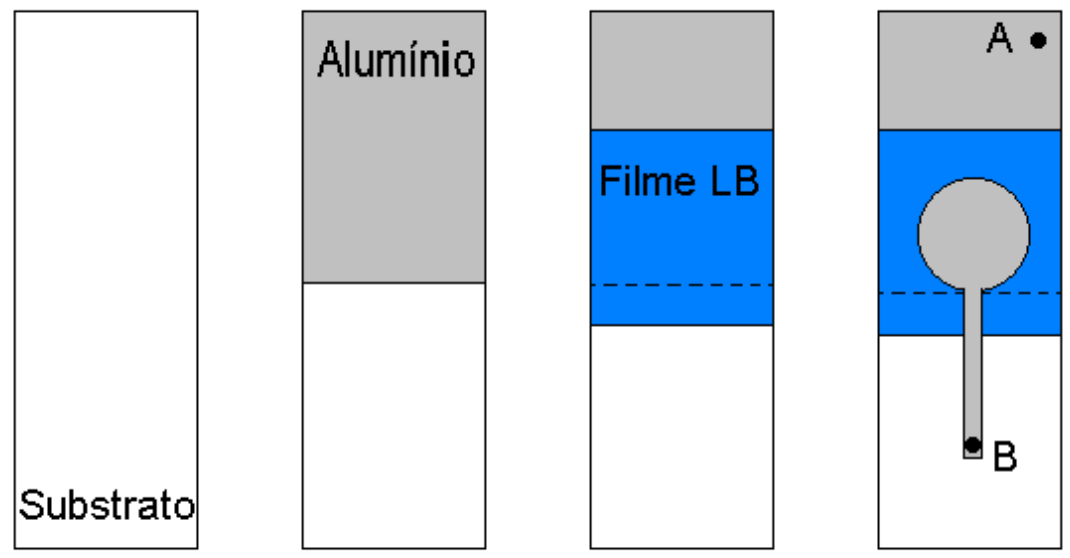

\section{FIGURA 65 - Representação esquemática da disposição dos contatos elétricos nas medidas de condutividade a.c.. A e B representam os pontos nos quais foram presos os fios para realização das medidas.}

As medidas de impedância são obtidas diretamente através da ponte em função da freqüência de um campo elétrico oscilante, que varia na faixa citada acima, e as componentes real e imaginária são obtidas, respectivamente, através das expressões:

$\sigma^{\prime}(\omega)=\frac{d}{A_{e}} \cdot \frac{Z^{\prime}}{\left(Z^{\prime}\right)^{2}+\left(Z^{\prime \prime}\right)^{2}}$

$\sigma^{\prime \prime}=\frac{d}{A_{e}} \cdot \frac{Z^{\prime \prime}}{\left(Z^{\prime}\right)^{2}+\left(Z^{\prime \prime}\right)^{2}}$

Nas equações acima $d$ é a espessura da amostra, $A_{e}$ a área de contato do eletrodo de medida sobre a amostra, e $Z^{\prime}(\omega)$ e $Z^{\prime \prime}(\omega)$ as componentes real e imaginária da impedância.

O processamento do sinal é feito representando a amostra por combinações de resistores e capacitores [113]. Todos os experimentos foram realizados a 
temperatura ambiente. Foi utilizado um impedanciômetro Solartron modelo 1260 impedance/Gain Phase Analyser ligado a um estabilizador de voltagem de 1KVA e a um filtro de linha. Esse aparelho é controlado por um microprocessador. O equipamento está conectado a um microcomputador que faz a aquisição dos dados experimentais. As amostras foram colocadas dentro de um criostato de fluxo de calor da JANIS, modelo SVT, com o intuito de minimizar interferências de campos externos durante a realização das medidas.

\section{3) Resultados e discussão}

\subsection{1) Medidas de condutividade d.c.}

As primeiras medidas de $\sigma$ em filmes LB foram feitas variando-se a espessura do filme produzido e o intervalo de tempo entre sua fabricação e a realização da medida de condutividade. $O$ interesse maior era verificar se havia alguma variação na condutividade em função do tempo de armazenagem ou da espessura da amostra. As dificuldades experimentais, aqui, advêm do trabalho demorado de deposição de filmes LB com muitas camadas e da delicadeza das medidas de condutividade elétrica $(\sigma)$.

As características dos filmes LB analisados são apresentadas a seguir:

TABELA 9 - Resultados de condutividade elétrica (van der Pauw) em filmes LB de polianilina processada apenas com CSA, obtidos em subfases ácidas.

\begin{tabular}{|c|c|c|c|}
\hline № de camadas & $\sigma_{1}(\mathrm{~S} / \mathrm{cm})$ & $\sigma_{2}(\mathrm{~S} / \mathrm{cm})$ & $\Delta t$ \\
\hline 03 & $10^{-4}$ & $10^{-4}$ & 45 dias \\
\hline 04 & $10^{-5}$ & $10^{-4}$ & \\
\hline 10 & $10^{-5}$ & $10^{-5}$ & 240 dias \\
\hline 13 & $10^{-4}$ & $10^{-4}$ & \\
\hline 17 & $10^{-4}$ & $10^{-4}$ & \\
\hline 36 & $10^{-3}$ & $10^{-4}$ & \\
\hline 36 & $10^{-2}$ & $10^{-4}$ & 30 dias ( $m$-cresol $)$ \\
\hline
\end{tabular}


TABELA 10 - Resultados de condutividade elétrica (van der Pauw) em filmes LB de polianilina processada com CSA e m-cresol, obtidos em subfases ácidas.

\begin{tabular}{c|ccc}
$\mathbf{N}^{\mathbf{0}}$ de camadas & $\boldsymbol{\sigma}_{\mathbf{1}}(\mathbf{S} / \mathbf{c m})$ & $\boldsymbol{\sigma}_{\mathbf{2}}(\mathbf{S} / \mathbf{c m})$ & $\Delta \mathbf{t}$ \\
\cline { 2 - 4 } 03 & $10^{-4}$ & $10^{-4}$ & 45 dias \\
04 & $10^{-3}$ & & 30 dias \\
\hline 04 & $10^{-4}$ & $10^{-4}$ & 90 dias \\
26 & $10^{-4}$ & $10^{-5}$ & 30 dias \\
27 & $10^{-5}$ & $10^{-5}$ & 60 dias \\
\cline { 2 - 4 } 32 & $10^{-4}$ & $10^{-4}$ & 30 dias \\
\cline { 2 - 4 } & & & \\
\hline
\end{tabular}

TABELA 11 - Resultados de condutividade elétrica (van der Pauw) em filmes LB mistos de polianilina com estearato de cádmio.

\begin{tabular}{|c|c|c|c|c|c|}
\hline $\begin{array}{l}\text { Número de } \\
\text { camadas }\end{array}$ & $\sigma_{1}(\mathrm{~S} / \mathrm{cm})$ & $\sigma_{2}(\mathrm{~S} / \mathrm{cm})$ & $\Delta \mathrm{t}$ & $\begin{array}{l}\text { \% de PANi } \\
\text { em solução }\end{array}$ & Dopado \\
\hline 11 & $10^{-5}$ & $10^{-5}$ & 1 dia & $43 \%$ & Não \\
\hline 11 & $10^{-6}$ & $10^{-6}$ & 30 dias & $43 \%$ & Não \\
\hline 11 & $10^{-4}$ & $10^{-4}$ & 1 dia & $43 \%$ & Vapor $\mathrm{HCl}$ \\
\hline 21 & $10^{-5}$ & $10^{-5}$ & 9 dias & $50 \%$ & $3 \mathrm{~h}$ raios- $\mathrm{X}$ \\
\hline 21 & $10^{-5}$ & $10^{-6}$ & 30 dias & $50 \%$ & $6,5 \mathrm{~h}$ raios- $\mathrm{X}$ \\
\hline 21 & $10^{-4}$ & $10^{-4}$ & 7 dias & PANi/NMP & Vapor HCl \\
\hline
\end{tabular}

TABELA 12 -Resultados de condutividade elétrica (van der Pauw) em filmes LB de 16-mero processado com CSA e m-cresol, obtidos em subfases ácidas.

\begin{tabular}{c|ccc|}
$\mathbf{N}^{\mathbf{0}} \begin{array}{c}\text { de camadas } \\
(\mathbf{1 6} \text {-mero })\end{array}$ & $\sigma_{\mathbf{1}}(\mathbf{S} / \mathbf{c m})$ & $\boldsymbol{\sigma}_{\mathbf{2}}(\mathbf{S} / \mathbf{c m})$ & $\Delta \mathbf{t}$ \\
\cline { 2 - 4 } 11 & $10^{-5}$ & $10^{-5}$ & 1 dia \\
\cline { 2 - 4 } 11 & $10^{-5}$ & $10^{-5}$ & 4 dias $(m$-cresol $)$ \\
\hline
\end{tabular}


TABELA 13 - Resultados de condutividade elétrica (van der Pauw) em filmes LB mistos de 16-mero com estearato de cádmio.

\begin{tabular}{|c|c|c|c|c|c|}
\hline $\begin{array}{l}\text { Número de } \\
\text { camadas }\end{array}$ & $\sigma_{1}(\mathbf{S} / \mathbf{c m})$ & $\sigma_{2}(\mathrm{~S} / \mathrm{cm})$ & $\Delta t$ & $\begin{array}{c}\text { \% de 16-mero } \\
\text { em solução }\end{array}$ & Dopado \\
\hline 35 & $10^{-6}$ & $10^{-6}$ & 15 dias & 40 & Não \\
\hline 13 & $10^{-5}$ & $10^{-5}$ & 15 dias & 50 & Não \\
\hline 13 & $10^{-4}$ & $10^{-4}$ & 15 dias & 50 & Vapor $\mathrm{HCl}$ \\
\hline 17 & $10^{-5}$ & $10^{-5}$ & 15 dias & 50 & Não \\
\hline 26 & $10^{-5}$ & $10^{-5}$ & 15 dias & 60 & Não \\
\hline 17 & $10^{-5}$ & $10^{-5}$ & 15 dias & 75 & Não \\
\hline
\end{tabular}

TABELA 14- Resultados de condutividade elétrica (duas pontas) em filmes LB mistos de 16-mero com estearato de cádmio (50\%).

\begin{tabular}{c|c|c} 
No de camadas & $\sigma(\mathbf{S} / \mathbf{c m})$ & $\Delta \mathbf{t}$ \\
(16-mero) & & \\
63 & $10^{-5}$ & 45 dias \\
63 & $10^{-5}$ & 60 dias \\
31 & $10^{-5}$ & 61 dias \\
\hline
\end{tabular}

Nas Tabelas 9 e 10 são apresentadas medidas de $\sigma$ realizadas durante 0 trabalho de mestrado, em filmes LB de PANI, que serão utilizadas na comparação com os valores de condutividade obtidos em filmes mistos de PAni e 16-mero com estearato de cádmio, e filmes de 16-mero obtidos em subfases ácidas sem a presença de estearato de cádmio. Nos resultados das Tabelas 9, 10 e 12, todas as amostras foram produzidas em subfases ácidas, o que implica em filmes LB parcialmente dopados. Utilizou-se para formação dessas subfases diferentes tipos de ácidos (TFA, $\mathrm{HCl}$ e $\mathrm{H}_{2} \mathrm{SO}_{4}$ ), mantendo-se o valor de $\mathrm{pH}$ fixo em torno de dois.

Os resultados da Tabela 9 indicam não haver tendência ao aumento (ou diminuição) da condutividade com a espessura do filme, $\left(\sigma \sim 10^{-4} \mathrm{~S}_{\mathrm{cm}} \mathrm{cm}^{-1}\right)$. Quanto ao possível efeito de envelhecimento das amostras, nota-se uma pequena diminuição nos valores de $\sigma$ para intervalos de tempo superiores a dois meses de armazenamento $\left(10^{-5} \mathrm{~S} . \mathrm{cm}^{-1}\right)$. Mesmo assim a condutividade parece não variar significativamente 
devido a esse possível efeito de envelhecimento (apenas uma ordem de grandeza). Tentou-se ainda medir $\sigma$ em um mesmo filme LB, em intervalos periódicos de tempo. O único problema foi manter fixos os contatos na amostra, já que estes soltam-se facilmente ao menor esforço mecânico, o que acabou impossibilitando a realização de tal medida. Deve ser mencionado que o material utilizado para fixação dos contatos nos resultados apresentados nas Tab. 9 e 10 foi aquadag (tinta condutora a base de água), evitando-se o problema de difusão de solvente no filme LB. Posteriormente optamos pela tinta prata por permitir uma melhor adesão dos fios de ouro nas amostras. Com base nesses resultados iniciais de condutividade em filmes LB de PANi, obtidos em subfases ácidas, optamos em variar apenas a espessura nos filmes mistos, não nos atendo muito quanto a um possível efeito de envelhecimento das amostras, que foi notado como sendo inexpressivo (Tab. 9).

Observando os valores mostrados nas tabelas acima nota-se que tanto nos filmes puros obtidos em subfases ácidas quanto nos filmes mistos, para a PANi e 16mero, não há anisotropia nas medidas de $\sigma$, a não ser na amostra da Tabela 9, com 36 camadas. Esse filme LB foi exposto por aproximadamente um mês a vapores de $m$ cresol, que deve ter causado ordenamento preferencial na sua estrutura. De fato, estudos de viscosidade em filmes e soluções de polianilina processada com CSA, nos quais a quantidade de $m$-cresol era variada, confirmam que ocorrem variações estruturais nos filmes expostos a poucos minutos ao vapor deste agente plastificante que atua como dopante secundário na polianilina, com o aumento de pelo menos duas ordens de grandeza nos valores de condutividade [79], como observado aqui em filmes LB [6].

Outro fato a ser mencionado é que os efeitos de dopagem, expondo os filmes $\mathrm{LB}$ ao vapor de $\mathrm{HCl}$ e à radiação ionizante dos raios-X, não foram tão significativos nos filmes aqui apresentados como foram para filmes convencionais obtidos por “casting” [10]. Tanto para a PANi quanto para o 16-mero, em filmes LB puros ou mistos, observa-se nas Tabelas 10, 11 e 13 um acréscimo de apenas uma ordem de grandeza nas medidas de condutividade devido à dopagem química, pelo método de van der Pauw $\left(\sigma \cong 10^{-4} \mathrm{~S}_{\mathrm{cm}} \mathrm{cm}^{-1}\right)$.

Com o intuito de confirmar esse resultados processamos a polianilina com NMP, de acordo com o procedimento adotado por Dhanabalan et al [33], 
aproveitando sua presença no Grupo de Polímeros Prof. Bernhard Gross, em São Carlos. O mesmo procedimento foi adotado por Agbor et al [35], e Cheung et al [27], como descrito adiante. Foram adicionados 2,5 mg de PANi a 2,5 mg de Ast em 250 $\mu \mathrm{L}$ de ácido acético glacial. Nessa mistura adiciona-se $15 \mathrm{~mL}$ de NMP. A solução final é obtida filtrando-se a solução anterior após duas horas de agitação. Dhanabalan et al [33] realizaram as medidas de condutividade pelo método de quatro pontas colineares, fabricando o filme LB sobre contatos de ouro previamente depositados sobre o substrato. Obtiveram $10^{-4} \mathrm{~S} . \mathrm{cm}^{-1}$ para os filmes não dopados e $0,1 \mathrm{~S} / \mathrm{cm}$ para os filmes dopados em vapor de $\mathrm{HCl}$. Agbor et al [35] realizaram as medidas de condutividade pelo método de duas pontas, no plano da amostra, no vácuo, utilizando tinta prata para fixação dos contatos. Os filmes não dopados apresentaram valores de $\sigma$ em torno de $10^{-8} \mathrm{~S} \mathrm{~cm}^{-1}$, enquanto que os filmes dopados apresentaram valores de $\sigma$ em torno de $0,1 \mathrm{~S} \mathrm{~cm}^{-1}$. Cheung et al [26,27] realizaram as medidas de condutividade pelo método de van der Pauw, fixando os contatos na amostra com tinta prata ou pasta de grafite, como descrito na seção 6.2. Os filmes LB expostos ao vapor de $\mathrm{HCl}$ apresentaram valores de condutividade em torno de $1 \mathrm{~S} . \mathrm{cm}^{-1}$. Não foi relatado o valor de $\sigma$ de filmes não dopados. Para filmes expostos ao vapor de $\mathrm{HCl}$

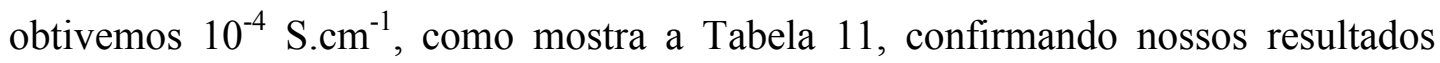
anteriores. As discrepâncias nesses valores de $\sigma$ obtidos por diferentes grupos de pesquisa podem ser atribuídas a vários fatores, tal como problemas de contato, embora o problema ainda continue sem solução.

Outra tentativa de confirmar nossos resultados foi realizar uma medida de condutividade através do método de quatro pontas colineares em um filme LB misto de PANi deuterada com CdSt (24 camadas), fabricado pela doutoranda Sarita Vera Mello. Imediatamente após dopar esse filme em vapor de $\mathrm{HCl}$ a condutividade ficou em torno de $10^{-3} \mathrm{~S} . \mathrm{cm}^{-1}$, e ao medi-la novamente um mês depois, o valor encontrado estava na ordem de $10^{-5} \mathrm{~S} . \mathrm{cm}^{-1}$. Como o $\mathrm{HCl}$ é muito volátil há uma perda de dopante com o tempo e consequentemente uma diminuição da condutividade ${ }^{3}$. Mencione-se aqui que as primeiras tentativas de medidas de condutividade em filmes LB de polianilina foram feitas pelo método de quatro pontas colineares, mas as amostras mostraram-se muito resistivas, havendo grandes flutuações durante as

\footnotetext{
${ }^{3}$ M.F. Rubner, comunicação pessoal
} 
medidas, dificultando a obtenção dos resultados. Com o método de van der Pauw, embora as flutuações continuassem durante as medidas, os resultados foram mais satisfatórios.

Devido ao aparato experimental, que possibilitou a obtenção de excelentes resultados, em diferentes materiais, permitindo ainda o modelamento de mecanismos de condução [113], foram realizadas medidas a.c. em um filme LB misto de CdSt, com o intuito de comparar os resultados.

\subsection{2) Medidas de condutividade a.c.}

As medidas de condutividade a.c. foram realizadas com a colaboração do doutorando Rodrigo F. Bianchi. A Figura 66 ilustra a variação da componente real da condutividade em um filme LB misto de PANi com CdSt, irradiado por raios-X em $90 \%$ de umidade em diferentes intervalos de tempo. As medidas apresentadas nessa seção foram preliminares e necessitam ser consideradas como tal.

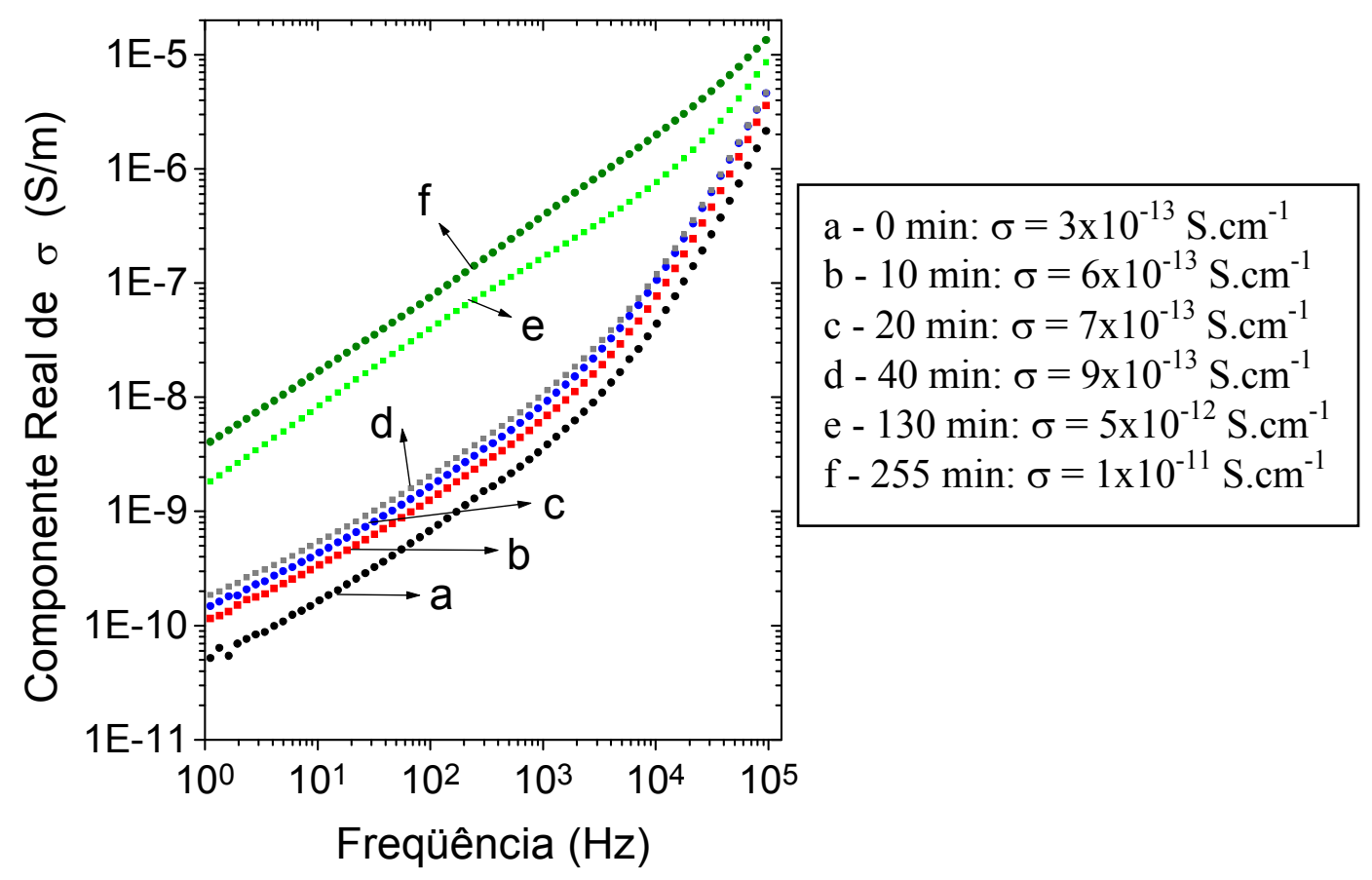

FIGURA 66 - Comportamento da componente real da condutividade complexa em função da freqüencia, em filmes LB mistos de PANi com CdSt.

O comportamento observado na Figura 66 é consistente com o relatado na literatura [113-115]. As curvas c e d na Figuras 66 ilustra medidas realizadas em um intervalo de tempo ( $\sim 10$ minutos) inferior ao necessário $(\sim 1,5$ hora $)$ para o sistema 
atingir o equilíbrio em uma atmosfera a 90\% de umidade. Nota-se através da Fig. 66 que há um ligeiro acréscimo na condutividade a $1 \mathrm{~Hz}$. com o aumento do tempo de exposição do filme LB aos raios-X. Esse mesmo comportamento não foi verificado nas medidas realizadas pelo método de van der Pauw. As medidas desta seção em amostras recém depositadas (desdopadas) são volumétricas e indicam valores de $\sigma$ $\left(\sim 10^{-13} \mathrm{~S}^{-\mathrm{cm}^{-1}}\right)$ pelo menos oito ordens de grandeza inferiores aos observados nas medidas d.c. $\left(\sim 10^{-5}{\mathrm{~S} . \mathrm{cm}^{-1}}^{-1}\right.$, obtidos através do método de duas pontas. Deve-se mencionar que os resultados a.c. em filmes "casting" de polianilina [113] são duas a

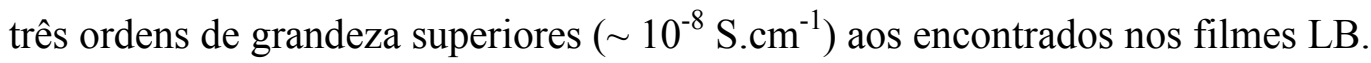

Apesar das diferenças, tanto nos valores quanto pelos métodos de medida de condutividade, o comportamento observado na Figura 67 é característico para a polianilina em função da variação do tempo de dopagem [113-120]. Nestas últimas referências a dopagem foi feita quimicamente.

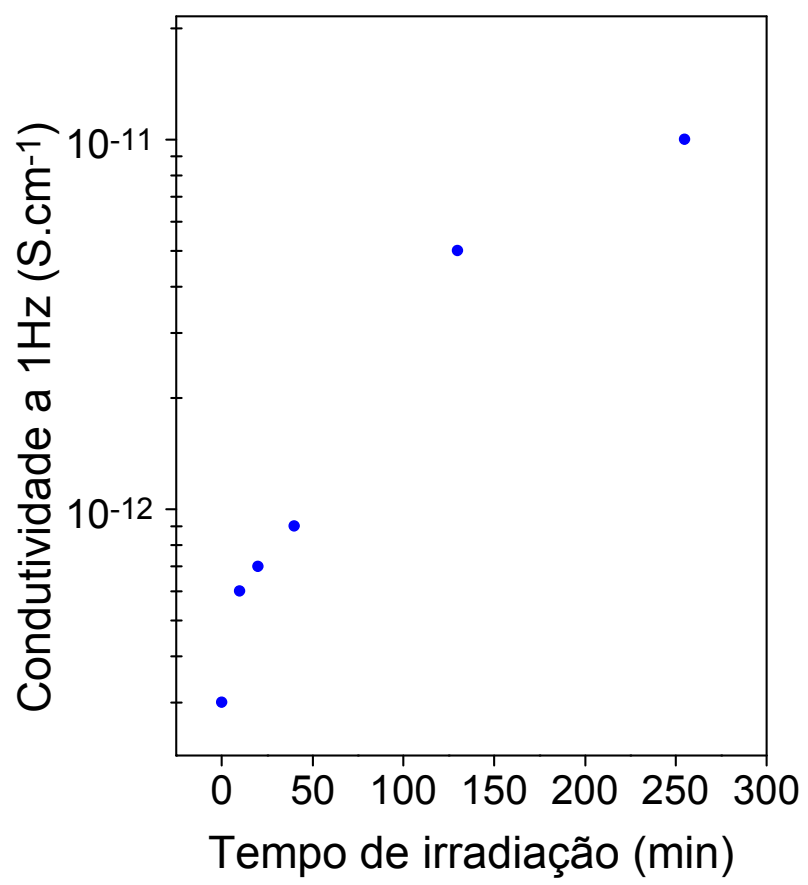

FIGURA 67 - Variação da condutividade a $1 \mathrm{~Hz}$ em filmes LB mistos de PANi/CdSt, variando o tempo de exposição da amostra aos raios- $X$.

Observa-se nesta Figura 67 que após um tempo prolongado de exposição do filme LB aos raios-X (90\% de umidade), a componente d.c. da condutividade tende a uma saturação, como observado em outros tipos de filmes dopados com ácidos inorgânicos [113-120]. Os pontos referentes a um intervalo de tempo entre 20 e 50 
minutos de irradiação fogem um pouco do comportamento previsto, pois durante a realização dessas medidas não foi dado tempo suficiente para que fosse atingida a condição de $90 \%$ de umidade, durante a irradiação. Embora preliminar, esse resultado serve para mostrar a importância do efeito de umidade nas medidas de exposição dos filmes LB aos raios-X.

\section{4) Conclusões}

Existem diferenças significativas nos resultados encontrados por diferentes métodos de medidas. Os valores encontrados pelos métodos de duas pontas e van der Pauw estão na ordem de $10^{-5} \mathrm{~S} / \mathrm{cm}$, em filmes LB produzidos em diferentes condições (filmes mistos com CdSt, de PANi pura obtidos em subfases ácidas, e expostos aos raios-X).

A condutividade em filmes LB de PANi é sempre menor do que em filmes convencionais. Isso ocorre tanto para medidas volumétricas, ou de superfície, para filmes dopados. Esse resultado é, aparentemente, contrário ao esperado, pois os filmes LB são mais organizados. Sua condutividade menor pode estar ligada à conectividade de domínios condutores. Embora os filmes LB tenham, em princípio, menos defeitos, a conectividade é prejudicada mais facilmente do que nos filmes convencionais, mais espessos.

Mesmo considerando apenas filmes LB de polianilinas, a condutividade d.c. dos filmes dopados é menor do que de outros trabalhos da literatura. Não temos explicação plausível para esta constatação. Diversas tentativas foram feitas para verificar se alguma condição experimental poderia estar afetando a condutividade, mas os resultados têm sido consistentemente reprodutíveis ao longo dos anos.

Diante desse impasse, iniciamos medidas a.c. num sistema cujos resultados têm se mostrado altamente confiáveis. Embora os resultados sejam preliminares, já foi possível verificar o efeito da irradiação de raios-X na condutividade volumétrica, consistente com o encontrado para dopagem química em outros tipos de filmes de PANi. Esse aumento de condutividade com a irradiação não é inconsistente com a ausência de efeito na condutividade d.c. (vide capítulo 5), pois esta última foi medida com o método de van der Pauw, portanto, condutividade de superfície. 


\section{CAPÍTULO 7}

\section{7) Conclusões gerais}

Os resultados apresentados no capítulo 2 mostram que é possível a formação de monocamadas estáveis de filmes mistos de PANi e 16-mero com estearato de cádmio, dependendo da percentagem adicionada, de polímero ou oligômero na solução que dará origem ao filme de Langmuir. Não foi notada nenhuma relação entre a pressão de colapso e a percentagem adicionada de material na solução, embora haja variações nas curvas (П X A) que aparentaram não ser sistemáticas. Tanto para a PANi quanto para o 16-mero são formados sistemas nos quais há separação de fases nas monocamadas, ou seja, não há mistura em nível molecular desses materiais com o estearato de cádmio. Verificou-se um valor inicial não nulo para o potencial de superfície nas monocamadas de PANi e 16-mero, indicando a formação de domínios no estágio anterior à compressão dos filmes mistos. Os máximos valores atingidos pelo potencial de superfície, para a PANi e para o 16mero, são menores que os observados para a polianilina protonada em subfases ácidas (350 a $400 \mathrm{mV}$ ). Para os filmes mistos, possivelmente, há a perda da contribuição positiva da dupla camada formada na interface filme/subfase, uma vez que os mesmos são formados sobre subfases com valor de $\mathrm{pH}$ próximo a seis. Para a PANi, em subfases ácidas, as variações observadas nos valores de potencial de superfície são muito próximas na faixa de $\mathrm{pH}$ de 1 a $4(\sim 120 \mathrm{mV})$, podendo ser explicadas pelo modelo de Gouy-Chapman. O mesmo não ocorre com a POEA, possivelmente devido a efeitos estéricos entre os contra-íons do TFA e os grupos laterais substituintes (etoxi) na POEA. A adsorção de íons de carga oposta ao do filme na Langmuir, especialmente os mais hidrofóbicos, como no caso do TFA, cria a possibilidade de inversão de carga elétrica na superfície, e conseqüentemente de $\Psi_{0}$. Isso explicaria a discrepância nos valores observados de $\Delta \mathrm{V}$ para a POEA quando se utiliza TFA na subfase. 
A caracterização dos filmes LB mistos de polianilina, ou 16-mero, com estearato de cádmio indicou que os filmes recém depositados encontram-se desdopados nos espectros de UV-vis. A exposição dos filmes ao vapor de $\mathrm{HCl}$ permite novamente o processo de dopagem. Notou-se uma relação linear entre a absorbância e o número de camadas depositadas, tanto nos filmes mistos de PANi quanto nos de 16-mero, o que é indicativo da formação de uma estrutura de multicamadas nos filmes LB fabricados. Para o 16-mero, acima de 75\% de oligômero em massa na solução, essa linearidade foi quebrada e tal fato foi atribuído à perda de estabilidade da monocamada, que acaba comprometendo o processo de transferência dos filmes de Langmuir para a superfície dos substratos. Os resultados de FTIR indicaram a presença de polianilina com CdSt, e 16-mero com CdSt nos filmes LB. A ausência de inclinação nos espectros na região de 2000 a $4000 \mathrm{~cm}^{-1}$ confirma que os filmes desdopados não estão protonados, corroborando os resultados de UV-vis. A difração de raios-X indicou a presença de domínios separados entre os materiais poliméricos e o estearato de cádmio. $\mathrm{O}$ aumento da percentagem em massa de polímero, ou oligômero, na solução afeta a ordem de empacotamento dos domínios de CdSt nos filmes Langmuir-Blodgett. Esse aumento na percentagem leva também a um ligeiro aumento no valor da distância entre bicamadas de estearato de cádmio, provavelmente porque moléculas de PANi ou 16-mero possam estar localizadas entre os planos polares de CdSt nos filmes LB, devido à perda de estabilidade da monocamada.

A condutividade elétrica dos filmes LB mistos não dopados é da ordem de $10^{-5} \mathrm{~S} \mathrm{~cm}^{-1}$, enquanto que para os filmes expostos ao vapor de $\mathrm{HCl}$ durante dois minutos é de $10^{-4}{\mathrm{~S} . \mathrm{cm}^{-1}}^{-}$, independentemente da percentagem utilizada de PANi ou 16-mero. Os resultados elipsométricos sugerem a formação de filmes LB mistos de 16-mero/CdSt mais compactos que os de $\mathrm{PANi} / \mathrm{CdSt}$, uma vez que os valores para o índice de refração nos filmes de 16-mero foram um pouco maiores que os observados nos filmes com polianilina. Observou-se também que há a formação de espaços vazios (porosidade) em ambos tipos de filmes LB.

Pela similaridade dos resultados, o 16-mero é um material melhor de se trabalhar para a fabricação de filmes LB que a polianilina, sendo mais fácil de processar e de formar monocamadas, mesmo sobre subfases ácidas, o que acaba 
facilitando a transferência dos filmes para a superfície de substratos. A formação de monocamadas mistas com CdSt é outro processo que melhora a aplicação da técnica Langmuir-Blodgett, permitindo a fabricação de filmes LB bastante uniformes.

A presença de $m$-cresol para o processamento da polianilina implica num aumento nos valores de área molecular média, tanto para as monocamadas mistas quanto para aquelas de polímero puro formadas sobre subfases ácidas. Esse aumento é indicativo de que há um efeito de memória nas monocamadas devido à utilização de $m$-cresol para processamento do polímero. A maneira segundo a qual o polímero é processado tem um forte impacto na conformação molecular da polianilina, que por sua vez irá influenciar a formação das monocamadas e a fabricação dos filmes LB. Embora essas alterações tenham sido observadas nos espectros de UV-vis, elas não foram fortes o suficiente para causar variações significativas nas medidas de condutividade elétrica, pelo método de van der Pauw. Essas variações conformacionais não alteram também a ordem de empacotamento dos domínios de CdSt no caso dos filmes mistos.

A exposição de filmes LB mistos de polianilina com estearato de cádmio aos raios-X tem como conseqüência variações sistemáticas nos espectros de UV-vis. Com o aumento do tempo de irradiação há um desvio da banda de absorção em 600 $\mathrm{nm}$ para a região de comprimentos de onda maiores. Após o aparecimento da banda de absorção na região de $800 \mathrm{~nm}$ o espectro de UV-vis mantém-se invariável com o aumento do tempo de exposição. Resultados de XRD e FTIR indicam que a irradiação parece não afetar a ordem nos domínios de estearato de cádmio nos filmes LB, em contraste com o que ocorre com os filmes LB mistos submetidos à dopagem química. O tratamento com ácidos resulta na destruição dos domínios isolantes de CdSt, o que possivelmente pode melhorar a contribuição interdomínios da polianilina na condutividade elétrica. Entretanto, a estrutura de domínios é preservada mesmo após a exposição aos raios-X, ou seja, a irradiação não altera a contribuição interdomínios para a condutividade. Medidas realizadas em atmosferas de oxigênio, nitrogênio, argônio, no vácuo, em atmosfera ambiente ( $\sim 50 \%$ de umidade) e atmosferas com umidades relativas superiores a $85 \%$, indicam claramente que em ambientes mais úmidos e filmes mais finos o processo de dopagem é acelerado. A posterior desdopagem em vapor de amônia é um processo parcialmente reversível 
nos filmes irradiados com até $50 \%$ de umidade. Para os filmes irradiados em ambientes muito úmidos (90\% de umidade) essa desdopagem acarreta num alargamento da banda de absorção na região entre 600 e $800 \mathrm{~nm}$.

Graças à excelente uniformidade e controle de espessura nos filmes LB, verificou-se que o efeito causado pela exposição desses filmes aos raios-X é intensificado também em filmes mais finos, mantidos em ambientes bem úmidos (90\% de umidade). A espessura do filme LB altera o tempo de irradiação necessário para o aparecimento da banda polarônica nos espectros de UV-vis (dopagem).

A exposição de filmes LB recém depositados ao vapor de $\mathrm{HCl}$, e posteriormente irradiados em atmosfera ambiente a $50 \%$ e a $90 \%$ de umidade, apresentaram um decréscimo no valor máximo de absorção. Possivelmente a exposição aos raios-X de filmes $\mathrm{LB}$ dopados em $\mathrm{HCl}$ favoreça a evaporação do $\mathrm{HCl}$, implicando numa diminuição de portadores de carga. O efeito de umidade é de crucial importância nas alterações causadas pela exposição dos filmes aos raios-X.

O efeito de ionização da atmosfera de medida gera espécies químicas, como espécies ácidas iônicas, que através da absorção de água pela amostra podem interagir com as cadeias poliméricas estimulando o processo de protonação na polianilina. Um outra possibilidade seria a quebra de moléculas de água adsorvidas pela matriz polimérica pelos fótons de raios-X ou por elétrons secundários, que permitiriam a dopagem da polianilina.

As medidas de condutividade elétrica realizadas pelo método de van der Pauw em filmes LB de polianilina e 16-mero puros, e em filmes LB mistos de polianilina com estearato de cádmio e 16-mero com estearato de cádmio, contendo diferentes números de camadas, com alguns deles dopados em vapor de $\mathrm{HCl}$, indicam valores de condutividade no intervalo de $10^{-5}$ a $10^{-4} \mathrm{~S}_{\mathrm{cm}} \mathrm{cm}^{-1}$. Embora haja flutuações, os valores de $\sigma$ não se afastam muito do intervalo acima. Medidas volumétricas de condutividade, realizadas pelo método de dois pontos, em amostras de PANi e 16-mero indicam os mesmos valores de condutividade que os encontrados pelo método de van der Pauw $\left(\sim 10^{-5} \mathrm{~S}_{\mathrm{cm}} \mathrm{cm}^{-1}\right)$. Não há um consenso na literatura a respeito dos valores de $\sigma$ em filmes LB de PANi. Ainda que o material tenha sido processado de diferentes formas, por diferentes grupos de pesquisa, e diferentes métodos de medida (dois pontos e van der Pauw), alguns dos resultados corroboram 
os valores de 0,1 e 1 S.cm ${ }^{-1}$ para os filmes dopados em vapor de $\mathrm{HCl}$ $[26,27,31,32,35,46]$. Granholm et al [46] processaram a PANi como descrito nesta tese, utilizando CSA e $m$-cresol, obtendo um valor de $10^{-3}{\mathrm{~S} . \mathrm{cm}^{-1}}^{\text {de condutividade }}$ volumétrica. É interessante notar que observamos a mesma variação (duas ordens de grandeza) nos valores de condutividade, em filmes LB, que a observada devido a exposição de filmes casting de PANi ao vapor de $m$-cresol [79].

Medidas de condutividade a.c. em filmes LB mistos de polianilina com estearato de cádmio, expostos aos raios-X em diferentes taxas de irradiação, foram realizadas. A extrapolação da curva para a componente real de $\sigma$, para valores baixos de freqüência, fornece o valor da condutividade d.c. da amostra. Essas medidas com campo alternado permitiram verificar uma variação de duas ordens de grandeza devido à exposição dos filmes aos raios-X, o que não foi possível com a técnica de van der Pauw. Os valores extrapolados para a condutividade d.c. para filmes recém depositados é da ordem de $10^{-13}{\mathrm{~S} . \mathrm{cm}^{-1}}^{\text {. }}$

A discrepância entre os valores de condutividade para filmes LB obtidos em diferentes laboratórios não é explicada. Ainda assim, acreditamos que a condutividade nos filmes LB é menor do que a observada em filmes "casting". Entre os vários possíveis fatores para essa menor condutividade, acreditamos que um dos principais seja a possibilidade de formação de pontes de hidrogênio entre diferentes partes de uma mesma cadeia polimérica durante a formação das monocamadas, favorecidas pela interação com a água, com a perda parcial de $m$-cresol e dos contraíons do CSA para a subfase, e com a compressão do filme de Langmuir. Isso levaria à formação de uma conformação molecular mais enovelada, que acabaria determinando em grande parte algumas características do filme LB formado. Por exemplo, a conformação assumida pode ser tal que a condução interdomínios seja afetada de forma a diminuir a condutividade macroscópica observada. Quanto às pequenas variações causadas pela exposição desses filmes aos raios-X, é provável que a presença de água favoreça a formação de portadores de carga, só que em quantidades muito menores do que quando ácidos inorgânicos são utilizados, daí a pequena variação de $\sigma$. Embora os mecanismos de dopagem sejam diferentes, o processo é parcialmente reversível pela exposição dos filmes irradiados ao vapor de amônia. 


\section{REFERÊNCIAS BIBLIOGRÁFICAS}

[1] YU, G.; HEEGER, A.J., Synthetic Metals, 85, 1183, 1997.

[2] SCOTT, J.C.; CARTER, S.A.; KARG, S.; ANGELOPOUlOS, M.A., Synthetic Metals, 85, 1197, 1997.

[3] HALLIDAY, D.P.; EGGLESTON, J.M.; ADAMS, P.N.; PENTLAND, I.A.; MONKMAN, A.P., Synthetic Metals, 85, 1245, 1997.

[4] McGEHEE, M.D.; VACAR, D.; LEMMEN, U.; MOSES, D.; HEEGER, A.J., Synthetic Metals, 85, 1233, 1997.

[5] RIUL Jr., A.; MATTOSO, L.H.C.; MELlO, S.V.; TELlES, G.D.; OLIVEIRA Jr, O.N., Synthetic Metals, 71, 2067, 1995.

[6] RIUL Jr., A.; MATTOSO, L.H.C.; TElleS, G.D.; HERRMANN, P.S.P.; COLNAGO, L.A.; PARIZOTTO, N.A.; BARANAUSKAS, V.; FARIA, R.M.; OLIVEIRA Jr, O.N., Thin Solid Films, 284-285, 177, 1996.

[7] MAcDIARMID, A.G.; EPSTEIN, A.J., Synthetic Metals, 65, 103, 1994.

[8] MAcDIARMID, A.G.; EPSTEIN, A.J., Synthetic Metals, 69, 85, 1995.

[9] MIN, Y.; XIA, Y.; MAcDIARMID, A.G.; EPSTEIN, A.J., Synthetic Metals, 69, 159, 1995.

[10] MALMONGE, J.A.; MATOSSO, L.H.C., Synthetic Metals, 84, 779, 1997.

[11] Malmonge, J.A., Preparação, caracterização e estudo do mecanismo de transporte de cargas em blendas do copolímero P(VDF-TrFE) com poli(ometoxianilina). São Paulo. Tese (Doutorado) - Instituto de Física de São Carlos, Universidade de São Paulo, 1997.

[12] ZHOU, H.C.; STERN, R.; BATICH, C.; DURAN, R.S.; Makrom. Chem., Rapid Comm., 11, 409, 1991.

[13] ZHOU, H.C.; DURAN, R.S, Polymer Reprints, 32, 1, 202, 1991.

[14] ZHOU, H.C.; BATICH, C.; DURAN, R.S, Polymer Reprints, 31, 2, 560, 1990.

[15] QUINT, R.; KNOLL, W.; HARA, M.; SASABE, H.; DURAN, R.S., Macromolecules, 28, 4029, 1995.

[16] ANDO, M.; WATANABE, Y.; YIODA, T.; HONDA, K.; SHIMIDZU, T., Thin Solid Films, 179, 225, 1989. 
[17] GONÇALVES, D.; FARIA, R.M.; OLIVEIRA Jr, O.N.; SWORAKOWSKI, J., Synthetic Metals, 55-57, 3819, 1993.

[18] ROBITAILlE, L.; BERGERON, J-Y.; D'APRANO, G.; LECLERC, M.; CALLENDER, C.L., Thin Solid Films, 244, 728, 1994.

[19] MATTOSO, L.H.C.; MELlO, S.V.; RIUL Jr., A.; OLIVEIRA Jr., O.N.; FARIA, R.M., Thin Solid Films, 244, 714, 1994.

[20] MELlO, S.V.; MATTOSO, L.H.C; FARIA, R.M.; OLIVEIRA Jr., O.N., Synthetic Metals, 71, 2039, 1995.

[21] MELlO, S.V.; MATTOSO, L.H.C.; OLIVEIRA Jr., O.N.; FARIA, R.M., Thin Solid Films, 284-285, 187, 1996.

[22] PADDEU, S.; RAM, M.K.; NICOLINI, C., J. Phys. Chem. B, 101, 4759, 1997.

[23] CLARK, R.L.; YANG, S.C., Synthetic Metals, 29, E337, 1989.

[24] PARK, Y.W.; MOON, J.S.; BAK, M.K.; JIN, J-I., Synthetic Metals, 29, E389, 1989.

[25] STEIGER, R., Helvetica Chimica Acta, 54, 8, 2645, 1971.

[26] CHEUNG, J.H.; PUNKKA, E.; RIKUKAWA, M.; ROSNER, R.B.; ROYAPPA, A.T.; RUBNER, M.F., Thin Solid Films, 210-211, 246, 1992.

[27] CHEUNG, J.H.; RUBNER, M.F., Thin Solid Films, 990, 244, 1994.

[28] ROYAPPA, A.T.; RUBNER, M.F., Langmuir, 8, 3168, 1992.

[29] PUNKKA, E.; LAAKSO, K.; STUBB, H.,LEVON, K.; ZHENG,W.-Y., Thin Solid Films, 243, 515, 1994.

[30] SUWA, T.; KAKIMOTO, M.; IMAI, Y.; ARAKI, T.; IRIYAMA, K., Mol. Cryst. Liq. Cryst., 255, 45, 1994.

[31] DHANABALAN, A.; DABKE, R.B.; DATTA, S.N.; PRASANTH KUMAR, N.; MAJOR, S.S.; TALWAR, S.S.; CONTRACTOR, A.Q., Thin Solid Films, 295, 255, 1997.

[32] DHANABALAN, A.; DABKE, R.B.; PRASANTH KUMAR, N.; TALWAR, S.S.; MAJOR, S.S.; LAL, R.; CONTRACTOR, A.Q., Langmuir, 13, 4395, 1997.

[33] RAM, M.K.; MALHOTRA, B.D., Polymer, 37, 4809, 1996. 
[34] RAM, M.K.; SUNDARESAN, N.S.; MALHOTRA, B.D., J. Phys. Chem., 97, $11580,1993$.

[35] AGBOR, N.E.; PETTY, M.C.; MONKMAN, A.P.; HARRIS, M., Synthetic Metals, 55, 3789, 1993.

[36] GOLDENBERG, L.M.; PETTY, M.C.; MONKMAN, A.P., J. Electrochem. Soc., 55-57, 3789, 1993.

[37] AGBOR, N.E.; PETTY, M.C.; MONKMAN, A.P., Sensors and Actuators B, 28, 173, 1995.

[38] RAMANATHAN, K.; RAM, M.K.; MALHOTRA, B.D., Materials Science and Engineering, C3, 159, 1995.

[39] CAO, Y.; SMITH, P.; HEEGER, A.J., Synthetic Metals., 48, 91, 1992.

[40] CAO, Y.; SMITH, P.; HEEGER, A.J., Synthetic Metals., 55-57, 3514, 1993.

[41] HEEGER, A.J., Synthetic Metals., 55-57, 3471, 1993.

[42] BEYER, G.; STECKENBIEGLER, B., Synthetic Metals, Short Communication, 60, 169, 1993.

[43] GRANHOLM, P.; PALOHEIMO, J.; STUBB, H., Synthetic Metals., 84, 783, 1997.

[44] PORTER, D.L.; THOMPSON, D.; BRADLEY, M., Thin Solid Films, 288, 268, 1996.

[45] LAVRIK, N.V.; ROSSI, D.; KAZANTSEVA, Z.I.; NABOK, B.A.; NESTERENKO, B.A.; PILESTKY, S.A.; KALCHENKO, V.I.; SHIVANIUK, N. A.; MARKOVSKIY, L.N., Nanotechnology, 7, 315, 1996.

[46] GRanholm, P.; PAloheimo, J.; StubB, H., Phys. Rev. B, 55, 84, 13650, 1997.

[47] PAl, A.J.; ÖStergard, T.; PAlOHEIMO, K-M.; STUBB, H., Appl. Phys. Lett., 70, 15, 2022, 1997.

[48] ÖSTERGARD, T.; PAlOHEIMO, K-M.; PAL, A.J.; STUBB, H., Synthetic Metals., 88, 171, 1997.

[49] GAINES Jr., G.L., "Insoluble monolayers at liquid-gas interfaces”, Interscience, New York, 1966.

[50] MATTOSO, L.H.C.; MACDIARMID, A.G.; EPSTEIN, A.J., Synthetic Metals, 68, 1, 1994. 
[51] MAcDIARMID, A.G., Synthetic Metals, 84, 27, 1997.

[52] ZHANG, W.J.; FENG, J.; MAcDIARMID, A.G.; EPSTEIN, A.J., Synthetic Metals, 84, 119, 1997.

[53] PETTY, M.C., "Langmuir-Blodgett Films, An Introduction”, University of Durham, UK, Cambridge University Press, 1996

[54] DHANABALAN, A.; RIUL Jr. A.; OLIVEIRA Jr. O.N., Supramolecular Science, no prelo.

[55] DHANABALAN, A.; RIUL Jr. A.; MATTOSO, L.H.C.; OLIVEIRA Jr. O.N., Langmuir, 13, 4882, 1997.

[56] OLIVEIRA Jr., O.N., "Electrical properties of Langmuir monolayers and deposited Langmuir-Blodgett films", $\mathrm{PhD}$ (thesis), University of Wales, U.K., 1990.

[57] TAYLOR, D.M.; OLIVEIRA Jr., O.N.; MORGAN H., J. Coll. and Interface Sci., 139, 508, 1990.

[58] MELlO, S.V., "Síntese e caracterização da poli(o-etoxianilina) e seu processamento pela técnica de Langmuir-Blodgett”. São Paulo, 1994 Instituto de Química de São Carlos, Universidade de São Paulo.

[59] POUGET, J.P.; OBLKOWSKI, Z.; NOGAMI, Y.; ALBOUY, P.A.; LARIDJANI, E.J.; OH, E.J.; MIN, Y.; MAcDIARMID, A.G.; SUKAMOTO, J.; EPSTEIN, A.J., Synthetic Metals, 65, 131, 1994.

[60] FOCKE, W.W.; WNECK, G.E.; WEI, Y., J. Phys. Chem., 91, 5813, 1987.

[61] VAlleAU, J.P.; TORRIE, G.M., J. Phys. Chem., 76, 4623, 1992.

[62] GUR, Y.; RAVINA, I.; BABHCHIN, A.J., J. Colloid and Interface Science, 64, 333, 1978.

[63] SHAW, J.D., "Introdução à química de colóides e de superficies”, ed. Edgard Blucher, EDUSP, 1975.

[64] ROBERTS, G.G., “Langmuir-Blodgett films”, ed. Plenum Press, New York, 1990.

[65] SILVERSTEIN, R.M.; BASSLER, G.C.; MORRIL, T.C., "Spectroscopy identification of organic compounds, $5^{\text {th }}$ ed., John Wiley and Sons, Toronto, 1991. 
[66] DHANABAlan, A.; TAlWAR, S.S.; MAJOR, S., Thin Solid Films, 210, $76,1996$.

[67] RIUL Jr., A.; HAAS, H.; DHANABALAN, A.; COTTA, M.A.; OLIVEIRA Jr., O.N., "A morphological investigation of mixed polyaniline/cadmium stearate Langmuir monolayers", $4^{0}$ Congresso Brasileiro de Polímeros, 28 de Setembro a 02 de Outubro, Salvador, 1997.

[68] ITOH, I.; IWAMOTO, M., Appl. Phys. Lett., 68, 2714, 1996.

[69] CONSTANTINO, C.J.L.; JULIANI, L.P.; BOTARO, V.R.; BALOGH, D.T.; PEREIRA, M.C.; TICIANELLI, E.A.; CURVELLO, A.A.S.; OLIVEIRA Jr., O.N., Thin Solid Films, 824-285, 191, 1996.

[70] MULLER, R.H., "Techniques for characterization of electrodes and electrochemical processes”, ed. John Wiley and Sons, New York, 1991.

[71] REDONDO, A.; TICIANELLI, E.A.; SHIMSHON, G., Synthetic Metals, 29, E265, 1989.

[72] HECHT, E., "Optics", $2^{\text {nd }}$ edition, Addison Wesley Publishing Company, Massachusetts, 1990.

[73] JENKINS, F. A.; WHITE, H.E., "Fundamentals of optics", $4^{\text {th }}$ edition, MacGraw-Hill, Inc., 1976.

[74] CRUZ, C.M.G.S.; TICIANELLI, E.A., Journal of Electroanalytical Chemistry, 488, 1-2, 185, 1997.

[75] KIM, D.R.; CHA, W.; PAIK, W-K., Synthetic Metals, 84, 759, 1997.

[76] A. RIUL Jr.; A. DHANABALAN; L.H.C. MATTOSO; L.M. DE SOUZA; E.A. TICIANELLI; O.N. OLIVEIRA Jr, Thin Solid Films, no prelo.

[77] LECOURT, B.; BLAUDEZ, D.; TURLET, J.M., “Anisotropy in LangmuirBlodgett films studied by generalized spectroscopy ellipsometry”, The Eighth International Conference on Organized Molecular films, 24 a 29 de Agosto, Asilomar, Estados Unidos da América, 1997.

[78] OIKKONEN, M., J. Appl. Phys., 62, 4, 1385, 1987.

[79] AVLYANOV, J.K.; MIN, Y.; MAcDIARMID, A.G.; EPSTEIN, A.J., Synthetic Metals, 72, 65, 1995.

[80] MIN, Y.; XIA, Y.; MAcDIARMID, A.G.; EPSTEIN, A.J., Synthetic Metals, 69, 159, 1995. 
[81] MELLO, S.V.; RIUL Jr, A.; MATTOSO, L.H.C.; FARIA, R.M.; OLIVEIRA Jr., O.N., Synthetic Metals, 84, 773, 1997.

[82] IKKALA, O.T.; PIETILÄ, L-O; AHJOPALO, L.; ÖSTERHOLM, H.; PASSINIEMI, P.J., J. Chem. Phys., 103, 22, 9855, 1995.

[83] IKKALA, O.T.; PIETILÄ, L-O; PASSINIEMI, P.J; VIKKI, T.; ÖSTERHOLM, H.; AHJOPALO, L.; ÖSTERHOLM, J.-E., Synthetic Metals, 84, 55, 1997.

[84] ZHENG, W.; MIN, Y.; MAcDIARMID, A.G.; ANGELOPOULOS, M.; LIAO, Y-H.; EPSTEIN, A.J., Synthetic Metals, 84, 109, 1997.

[85] ZHENG, W., MIN, Y.; MAcDIARMID, A.G.; ANGELOPOUlOS, M.; LIAO, Y-H.; EPSTEIN, A.J., Synthetic Metals, 84, 63, 1997.

[86] ANGElOPOUlOS, M.; DIPIETRO, R.; ZHENG, W.; MAcDIARMID, A.G.; EPSTEIN, A.J., Synthetic Metals, 84, 35, 1997.

[87] ANGElOPOUlOS, M.; RAY, A.; MAcDIARMID, A.G.; EPSTEIN, A.J., Synthetic Metals, 21, 21, 1987.

[88] ALIX, A.; LEMOINE, V.; NECHTSCHEIN, M.; TRAVERS, J.P.; MENARDO, C., Synthetic Metals, 29, E457, 1989.

[89] TRAVERS, J.P.; GUYADEC, P.L.; ADAMS, P.N.; LAUGHLIN, P.J.; MONKMAN, A.P., Synthetic Metals, 69, 229, 1995.

[90] MATVEEVA, E.S.; CALLEJA, R.D.; PARKHUTIK, V.P., Synthetic Metals, 72, 105, 1995.

[91] MATVEEVA, E.S., Synthetic Metals, 79, 127, 1996.

[92] FOLCH, S.; GRUGER, A.; RÉGIS, A.; COLOMBAN, Ph., Synthetic Metals, 81, 221, 1996.

[93] ANGElOPOUlOS, M.; SHAW, J.M.; HUANG, W-S.; KAPLAN, R.D., Mol. Cryst. Liq. Cryst., 189, 221, 1990.

[94] “Handbook of Chemistry and Physics”, CRC Press, David R. Lide, 15-20, $73^{\text {rd }}$ ed., 1992-1993,

[95] M. WAN, Journal of Polymer Science: Part A: Polymer Chemistry, 30, 543, 1992.

[96] MONKMAN, A.P.; REBOUT, E.;PETR, A., Synthetic Metals, 84, 761, 1997. 
[97] DHANABALAN, A., RIUL Jr., A.; MALMONGE, J.A., FARIA, R.M.; OLIVEIRA Jr., O.N., Thin Solid Films, no prelo.

[98] ZHENG, W.; MIN, Y.; MAcDIARMID, A.G.; ANGElOPOUlOS, M.; LIAO, Y-H.; EPSTEIN, A.J., Synthetic Metals, 84, 63, 1997.

[99] Physics Abstracts, vol72, n877, 46534, 1969.

[100] COMPTON, A.H.; ALLISON, S.H., "X-rays in theory and experiment", $2^{\text {nd }}$ edition, D. Van Nostrand Company, Inc., 1954.

[101] PAULING, L., "The nature of the Chemical bond", $3^{\text {th }}$ edition, Cornell University, 1960.

[102] LARSON,H.V., Physical Review, 112 (6) 1927, 1958.

[103] BORTNER, T.E.; HURST, G.S., Physical Review, 93 (6) 1236, 1954.

[104] BAY, Z.; SELIGER, H.H., Physical Review, 120 (1) 141, 1960.

[105] DORMAN, F.H.; MORRISON, J.D.; NICHOLSON, A.J., The Journal of Chemical Physics, 32,(2) 378, 1960.

[106] RAPOSO, M.F.G.S., “Armazenamento e transporte de carga no tetrafluoretileno propileno", Dissertação (Mestrado), Universidade Nova de Lisboa - Lisboa (Portugal), 1994.

[107] RAPOSO, M.F.G.S.; RIBEIRO, P.A.; MENDES, J.N.M., Ferroelectrics, 134, 235, 1992.

[108] JOB, A.E.; GIACOMETTI, J.A.; MATTOSO, L.H.C., submetido para a revista Applied Physics Letters.

[109] WIEDER, H.H., "Laboratory notes on electrical and galvanomagnetic measurements", Materials Science Monographs, Elsevier, New York, 1979.

[110] SMITH, F.M., The Bell System Technical Journal, 37, 711, 1958.

[111] KEYWELL, F.; DOROSHEKI, G., The Review of Scientific Instruments, 31 (8) $833,1960$.

[112] van der PAUW, L.J., Phylips Res. Repts., 13, 1, 1958.

[113] BIANCHI, R.F., “Aplicações do modelo de distribuição aleatória de barreiras de energia livre em mecanismos de condução iônico ou eletrônico em sistemas desordenados: polanilinas, ormolites e perovskitas tipo $\mathrm{SrTi}_{(1-}$ ${ }_{x} \mathrm{Ru}_{x} \mathrm{O}_{3}$ “, São Paulo, 1997. Dissertação (Mestrado) - Instituto de Física de São Carlos, Universidade de São Paulo. 
[114] JAVADI, H.H.S.; ZUO, F.; CROMAK, K.R.; ANGELOPOULOS, M.; MAcDIARMID, A.G.; EPSTEIN, A.J., Synthetic Metals, 29, E409, 1989.

[115] STUBB, H.; PUNKKA, E.; PALOHEIMO, J., Materials Science and Engineerings, 10, 85, 1993.

[116] CHIANG, J.H.; MAcDIARMID, A.G., Synthetic Metals, 13 (205) 193, 1995.

[117] NECHTSCHEIN, M.; GENOUD, F.; MENARDO, C.; MINOGUCHI, M.; TRAVERS, J.P.; VILLERET, B., Synthetic Metals, 29, E211, 1989.

[118] YUE, J.; WANG, Z.H.; CROMACK, K.R., EPSTEIN, A.J.; MAcDIARMID, A.G., J. Am. Chem. Soc., 113, 2665, 1991.

[119] MAcDIARMID, A.G.; CHIANG, J.-C.; HALPERN, M.; HUANG, W.-S.; UM, S.-L.; SOMASIRI, N.L.D.; WU, W.; YANIGER, S.I., Mol. Cryst. Liq. Cryst., 121, 173, 1985.

[120] MAcDIARMID, A.G.; CHIANG, J.C.; RICHTER, A.F.; EPSTEIN, A.J., Synthetic Metals, 18, 285, 1987. 


\section{TRABALHOS FUTUROS}

i) continuação das medidas sobre dopagem com raios- $X$ com o intuito de verificar quais espécies podem ser formadas durante a ionização da atmosfera de medida. Medidas de EPR e RMN poderiam ajudar a esclarecer o mecanismo de dopagem envolvido, ainda desconhecido. Tentar medidas com filmes LB de 16-mero já que em experimentos preliminares obtivemos resultados diferentes entre filmes LB de PANi e 16-mero.

ii) caracterização elétrica de filmes LB de polianilina e 16-mero através de medidas a.c. e d.c. pelo sistema descrito no capítulo 6. Pela sensibilidade desse aparato experimental pode-se verificar melhor os efeitos do $m$-cresol na fabricação de filmes LB de PANi, e informações adicionais sobre a dopagem por raios-X. Pode-se ainda realizar um estudo comparativo mais sensível entre PANi e 16-mero, e a dopagem por raios-X com a dopagem química convencional, inclusive com medidas de microscopia de força atômica.

iii) realizar medidas com filmes mistos de 16-mero com percentagens próximas de $70 \%$, região em que parece haver uma transição de fase. Através de XRD, por exemplo, pode-se detectar a perda de organização dos domínios de CdSt.

iv) possíveis aplicações através da técnica LB, utilizando-se diferentes materiais como polianilina e polipirrol, na fabricação de sensores ou retificadores. 


\section{Artigos oriundos dessa tese de doutorado}

RIUL JR., A.; MATTOSO, L.H.C.; TELLES, G.D.; HERMANN, P.S.P.; COLNAGO, L.A.; PARIZOTTO, N.A.; BARANAUSKA, V.; FARIA, R.M.; OLIVEIRA JR., O.N.; Characterization of Langmuir-Blodgett films of parent polyaniline, Thin Solid Films, 284, 177 (1996).

MELLO, S.V.; RIUL JR., A.; MATTOSO, L.H.C.; FARIA, R.M.; OLIVEIRA JR., O.N.; Protonation Effects in polyaniline Langmuir films investigated by surface potential measurements, Synthetic Metals 84, 773 (1997).

DHANABALAN, A.; RIUL JR., A.; MATTOSO, L.H.C.; OLIVEIRA JR., O.N.; A study on composite Langmuir monolayers and Langmuir-Blodgett films from 16-mer polyaniline, Langmuir 13, 4882-4886 (1997).

DHANABALAN, A.; RIUL JR., A.; OLIVEIRA JR., O.N.; Composite Langmuir-Blodgett (LB) films of polyaniline and cadmium stearate, a ser publicado na revista Supramolecular Science.

DHANABALAN, A.; RIUL JR., A.; GONÇALVES, D.; OLIVEIRA JR., O.N.; Implications of using $\mathrm{m}$-cresol in the LB processing of polyaniline, a ser publicado na revista Thin Solid Films.

DHANABALAN, A.; MALMONGE, J.A.; RIUL JR., A.; FARIA, R.M.; OLIVEIRA JR., O.N.; A study on X-ray irradiation of composite polyaniline LB films, a ser publicado na revista Thin Solid Films.

RIUL JR., A.; DHANABALAN, A.; MATTOSO, L.H.C.; DE SOUZA, L.M.; TICIANELLI, E.A.; OLIVEIRA JR., O.N.; Characterization of 16-mer polyaniline composite LB films, a ser publicado na revista Thin Solid Films. 
Universidade de São Paulo

Instituto de Física de São Carlos

Instituto de Química de São Carlos

Escola de Engenharia de São Carlos

\section{Filmes de Langmuir e Langmuir-Blodgett de polianilinas}

Antonio Riul Jr.

Tese apresentada à área de Interunidades em Ciência e Engenharia de Materiais, do IFSC, IQSC, e EESC, para a obtenção do título de Doutor em Ciência e Engenharia de Materiais

ORIENTADOR: Prof. Dr. OSVALDO NOVAIS DE OLIVEIRA Jr. CO-ORIENTADOR: Dr. LUIZ HENRIQUE CAPPARELLI MATTOSO

SÃO CARLOS 
Riul Jr., Antonio

Filmes de Langmuir e Langmuir-Blodgett (LB) de polianilinas. São Carlos, 1998.

$145 \mathrm{p}$.

Tese (Doutorado) - Instituto de Física de São Carlos, 1998.

Orientador: Prof Dr. Osvaldo Novais de Oliveira Jr.

Co-orientador: Dr. Luiz Henrique Capparelli Mattoso

1.Langmuir- Blodgett. 2. Polianilina. 3. 16-mero.

I. Título 
Dedico essa Tese a Deus, à minha mãe, à memória de meu pai, aos meus irmãos, à minha esposa e filho, e a todos os meus amigos. 


\section{AGRADECIMENTOS}

A Deus pela alegria de viver.

Ao Prof. Osvaldo Novais de Oliveira Jr. pela orientação, amizade, apoio, confiança e ajuda, fornecidos ao longo desses anos de trabalho. Seu exemplo e dedicação contribuem muito para minha formação profissional. Seu trabalho foi além daquele de orientador, e espero um dia poder retribuir tudo o que tem feito por mim.

Ao Dr. Luiz H.C. Mattoso pela constante colaboração, dedicação, amizade e confiança. Suas sugestões sempre foram oportunas e seu apoio muito importante para a complementação desse trabalho. Não posso deixar de agradecer a oportunidade de trabalhar com o 16-mero. Indiretamente agradeço aqui ao Prof. Alan G. MacDiarmid pelo fornecimento do oligômero.

Ao Dr. Anantharaman Dhanabalan pela amizade e ajuda, além do constante aprendizado com novas técnicas de caracterização e discussões científicas. Sem sua colaboração com certeza essa tese de doutorado teria um rumo completamente diferente. As publicações, informações e o ritmo de trabalho adquirido foram conseqüência da convivência com ele. Obrigado Dhan.

À Sarita pela amizade sincera e confiança ao longo desses anos. Muito do que aprendi deve-se a sua inesgotável paciência e preciosa colaboração nas horas mais difíceis. Mais do que amiga foi meu braço direito.

Ao Casé pela amizade, discussões e sugestões nesses anos todos. Sua irreverência com certeza foi uma ponte de equilíbrio nas situações mais tensas, e sua alegria uma motivação. Obrigado pelas aulas de didática.

Ao Dr. Ailton Cavali, a Prof. Galina e ao Pira pela amizade e paciência. As medidas de condutância ainda irão servir.

Ao Bertho, Níbio, Ademir, Rosângela e Débora pela inestimável colaboração para que esse trabalho pudesse ser realizado com sucesso. Sem a presença de vocês esse Grupo não seria um lugar tão agradável de se conviver.

Ao Prof. Roberto M. Faria pela iniciativa em trabalhar com polímeros condutores, e pelas sugestões e discussões a respeito dos resultados de raios-X e condutividade elétrica.

Aos Profs. Guilherme, Mariângela e Giacometti pela agradável convivência e eventuais dicas.

À Dra. Liliane M. de Souza e ao Prof. Edson A. Ticianelli do IQSC pelas medidas de elipsometria, e discussões dos resultados obtidos. Ao Dr. Carlos Cruz pelo fornecimento da $\mathrm{PANi}_{2}$. 
Ao Mal, aos professores Wladmir Shapovalov e Heinz, ao Paulo e a Fátima, ao Haroldo e ao Rodrigo, pela amizade e colaboração nas medidas de raios-X e condutividade elétrica. As discussões foram muito construtivas, e a ajuda na hora certa. Obrigado pela atenção dada.

Ao Fonseca pelas dicas, e ao Tomioka pelo socorro computacional dado nos piores momentos. Ao Dante, Chicão, Mantovani, Lucas, Mauro, Mané, Pedrão, Romildo, Walterley, Xuxa, Ivo, Cristiano, Josmary, Cibele, Aldo, Débora, Célio, China, David, Celso, Glênio, e a Sandra pela amizade e convivência.

Ao Mauro e a Silvana do IQSC pela boa vontade e disposição nas medidas de FTIR. Ao Augusto do IFSC pelas medidas de difração de raios-X.

Ao Prof. Glaucius e à Wanda, do grupo de cristalografia, pela utilização do espectrofotômetro.

À Prof. Mônica Cotta do Instituto de Física Glebb Wattaghin, da Unicamp, e ao Herrmann, da EMBRAPA/CNPDIA de São Carlos, pelas medidas e discussões de AFM.

Ao Leonardo pela ajuda durante as medidas de microscopia óptica na EMBRAPA.

À minha mãe por todo amor dado. Sem o seu sacrifício constante e sua ajuda não sei o que seria de mim. Aos meus irmãos, meus tios Alan e Elcy, ao Galvão e a Maié, pela ajuda e pelo carinho nesses anos de mudança.

À Cá e ao Véio (André) pela alegria, amor, dedicação e paciência. A mudança foi brusca, mas muito boa.

Ao Pé, Guimes, Val, Mirão, Bahia, Zé do Rodo, Boy, Paulinho, Ciro, aos mestres João Pequeno, Diogo, Fernando, Dois de Ouro, Brandão, Lua de Bobó e a todo pessoal da academia por não me deixarem esquecer que a vida continua sendo a melhor escola.

À Élvia pelo apoio e incentivo para que eu não parasse as aulas de inglês.

Àqueles que eu esqueci, meu muito obrigado

À FAPESP pelo apoio financeiro. 


\section{ÍNDICE}

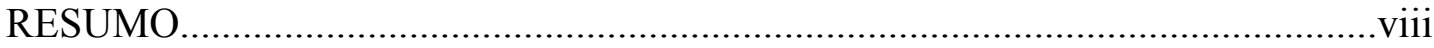

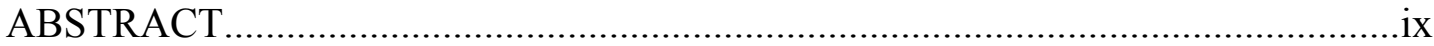

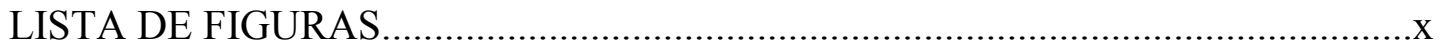

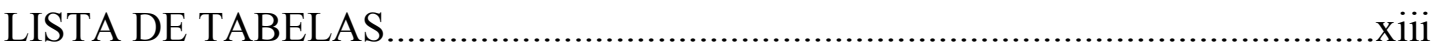

LISTA DE ABREVIATURAS E SIGLAS.............................................................

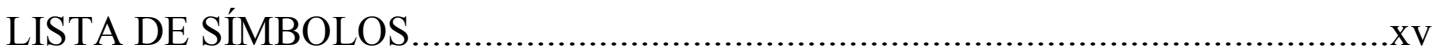

CAPÍTULO 1

Introdução _ 1

1.1) Motivação__ 1

1.2) Objetivos _ 3

1.3) Concepção da Tese __ 4

1.4) Revisão da literatura sobre filmes LB de polianilinas _ 5

CAPÍTULO 2 12

2) Caracterização dos filmes de Langmuir de Polianilinas__ 12

2.1) Filmes mistos de polianilina e 16-mero com estearato de cádmio___ 12

2.1.1) Introdução 12

2.1.2) Parte Experimental 13

2.1.2.1) Soluções de PANi 13

2.1.2.2) Soluções de 16-mero _ 13

2.1.3) Caracterização dos filmes de Langmuir ___ 14

2.1.3.1) Pressão de superfície $\quad 14$

2.1.3.2) Potencial de superfície___ 21

2.2) Efeito de protonação nas monocamadas, devido à variação do $\mathrm{pH}$ na subfase, verificado pelo potencial de superfície dos filmes de Langmuir de polianilinas. _ 24

2.2.1) Introdução

2.2.2) Parte experimental 26

2.2.3) Resultados 26

2.2.4) Conclusões 34

CAPÍTULO 3 _ 36

Caracterização dos filmes LB de polianilinas _ـ 36

3) Filmes LB mistos de PANi e 16-mero com estearato de cádmio __ 36

3.1) Introdução — 36

3.2) Parte experimental _ 37

3.3) Fabricação de filmes LB _ 38

3.4) Caracterização espectroscópica dos filmes LB _ 39

3.4.1) UV-vis 39

3.4.2) FTIR 43 
3.5) Caracterização estrutural dos filmes LB 45

3.6) Potencial de superfície e microscopia óptica dos filmes LB 49

3.7) Condutividade elétrica (van der Pauw) 51

3.8) Elipsometria 52

3.9) Conclusões 58

CAPÍTULO 4 59

4) Efeito do m-cresol na fabricação de filmes Langmuir-Blodgett (LB) de PANi 59

4.1) Introdução 59

4.2) Parte Experimental 60

4.3) Efeito do m-cresol na formação das monocamadas de polianilina 61

4.4) Caracterização dos filmes LB 64

4.4.1) UV-vis 64

4.4.2) Condutividade elétrica (van der Pauw)

4.4.3) Difração de raios-X

4.5) Discussão dos resultados 68

4.6) Conclusões 70

CAPÍTULO 5 71

5) Efeito da exposição de filmes LB mistos de PANi aos raios-X 71

5.1) Introdução 71

5.2) Parte experimental 71

5.3) Resultados e Discussão 73

5.4) Possível mecanismo para os efeitos dos raios- $X$ 95

5.4.1) Efeitos de ionização causados pelos raios-X e a importância da água no processo 96

5.4.2) Possibilidade da dopagem direta da polianilina pelos raios- $X$

5.4.3) Influência da água nas propriedades elétricas da polianilina

5.4.4) Hipóteses sobre a dopagem da PANi através dos raios-X

5.4.5) Comparação com dopagem por corona

5.5) Conclusões 101

CAPÍTULO 6 103

6) Condutividade Elétrica em filmes LB de polianilinas 103

6.1) Introdução 103

6.2) Experimental 109

6.3) Resultados e discussão 111

6.3.1) Medidas de condutividade d.c. 111

6.3.2) Medidas de condutividade a.c.

6.4) Conclusões 118

CAPÍTULO 7 119

7) Conclusões gerais 119 


\section{RESUMO}

RIUL Jr., A. Filmes de Langmuir e Langmuir-Blodgett de polianilinas. São Carlos, 1998. 145p. Tese (Doutorado) - Instituto de Física de São Carlos, Universidade de São Paulo.

Explorou-se a caracterização de monocamadas e filmes LB de polianilina (PANi), e um oligômero de polianilina, chamado aqui de 16-mero, com estearato de cádmio (CdSt). A análise dos filmes de Langmuir indicou que possivelmente não há mistura em nível molecular da PANi e do 16-mero com CdSt, ainda que a quantidade adicionada em solução de polímero ou oligômero influencie a estabilidade das monocamadas. Utilizou-se UV-vis, FTIR, difração de raios-X, condutividade elétrica, elipsometria, microscopia óptica e potencial de superfície para caracterização dos filmes LB. Os resultados de UV-vis indicaram uma transferência uniforme e ainda que os filmes recém depositados encontram-se desdopados. A análise de FTIR confirma a presença de CdSt nos filmes LB, e o efeito de desdopagem em subfases neutras, corroborando os resultados de UV-vis. A difração de raios-X indica a presença de domínios separados de PANi (e 16-mero) com CdSt nos filmes LB. Resultados elipsométricos indicaram uma espessura por camada em torno de $25 \AA$ A. A excelente uniformidade obtida nos filmes LB mistos foi comprovada pelos resultados de microscopia óptica e potencial de superfície. Esses filmes mistos apresentaram valores de condutividade elétrica em torno de $10^{-4}$ a $10^{-5}$

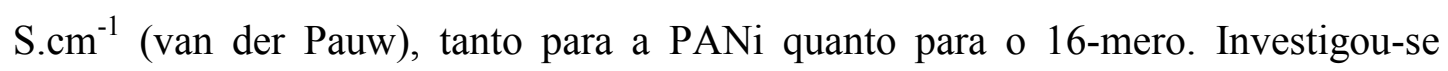
também o efeito da exposição dos filmes mistos PANi/CdSt aos raios-X. Nota-se um deslocamento para a região do vermelho, na região do visível, nos espectros de UVvis, similar à observada pela dopagem através de ácidos inorgânicos. Verificou-se que os efeitos de umidade da atmosfera de medida são predominantes nesse processo de dopagem. É feita uma análise dos resultados de condutividade elétrica, comparando-os com os encontrados na literatura.

Palavras-chave: Langmuir-Blodgett, polianilina, 16-mero 


\begin{abstract}
RIUL Jr., A. Filmes de Langmuir e Langmuir-Blodgett de polianilinas. São Carlos, 1998. 145p. Tese (Doutorado) - Instituto de Física de São Carlos, Universidade de São Paulo.
\end{abstract}

A study has been made of composite Langmuir and Langmuir-Blodgett (LB) films of polyaniline (PANi), and a polyaniline oligomer (16-mer polyaniline), with cadmium stearate $(\mathrm{CdSt})$. The monolayers studies pointed to a phase separated system containing the polymer (or the 16-mer) and $\mathrm{CdSt}$, with no mixing at the molecular level, although the relative contents of PANi and 16-mer in the solution have a strong influence on the monolayer stability. UV-vis, FTIR, X-ray diffraction (XRD), electrical conductivity, ellipsometry, optical microscopy and surface potential measurements were used in the LB film characterization. UV-vis results have shown a uniform transfer, with the as deposited films in the undoped state. FTIR results confirmed the presence of CdSt and undoped polyaniline (and 16-mer) in the transferred LB films, corroborating the UV-vis results. XRD has shown separated domains of CdSt and PANi (16-mer also) in the LB films. Ellipsometry data indicated a thickness of $25 \AA$ per deposited layer. The high uniformity in these mixed LB films was confirmed by optical microscopy and surface potential measurements. The electrical conductivity was approximately $10^{-5}$ to $10^{-4} \mathrm{~S}_{\mathrm{cm}} \mathrm{cm}^{-1}$ for both PANi and 16-mer. Mixed PANi/CdSt films were also exposed to X-ray irradiation. After a given dose rate there is a red shift in the UV-vis spectra from the $600 \mathrm{~nm}$ region to the $800 \mathrm{~nm}$ region, similar to the usual acid doping process observed in polyaniline. Humidity effects have a strong influence on the doping process. A comparison is made of the conductivity measurements made here with those reported in the literature.

Key-words: Langmuir-Blodgett, polyaniline, 16-mer polyaniline 


\section{LISTA DE FIGURAS}

FIGURA 1 - Representação esquemática da polianilina na base esmeraldina 2

FIGURA 2 - Curvas de pressão de superfície para as monocamadas mistas de polianilina com estearato de cádmio em diferentes composições de PANi.

FIGURA 3 - Curvas de pressão de superficie para as monocamadas mistas de 16-mero com estearato de cádmio em diferentes composições de 16-mero.

FIGURA 4 - Variação da área molecular por molécula de ácido, em função da percentagem de polímero nas monocamadas mistas de PANi/CdSt.

FIGURA 5 - Variação da área molecular média (4), extrapolada das curvas (ПX A), e da área crítica ( ), obtida das curvas ( $\triangle V X A)$, em função da variação da percentagem, em massa, de 16-mero na solução.

FIGURA 6 - Variação da área molecular, calculada em função da massa molar média de PANi e ácido esteárico, para diferentes percentagens de polímero na solução.

FIGURA 7 - Variação da área molecular, calculada em função da massa molar média de 16-mero e ácido esteárico, para diferentes percentagens de oligômero na solução, utilizadas para formação de monocamadas mistas de 16-mero/CdSt.

FIGURA 8 - Curvas de estabilidade das monocamadas mistas de 16-mero/CdSt nas diferentes percentagens utilizadas.

FIGURA 9 - Curvas de potencial de superfície em função da área por molécula para diferentes percentagens de PANi nas monocamadas mistas.

FIGURA 10 - Curvas de potencial de superfície em função da área por molécula para diferentes percentagens de 16-mero nas monocamadas mistas.

FIGURA 11 - Variação do valor máximo atingido pelo potencial de superfície nos filmes de Langmuir de PANi, em função da dopagem através de subfases ácidas. (a) $\mathrm{HClO}_{4}$; (b)

$\mathrm{CF}_{3} \mathrm{COOH}$; (c) $\mathrm{H}_{2} \mathrm{SO}_{4}$; (d) $\mathrm{HCl}$.

FIGURA 12 - Variação do valor máximo atingido pelo potencial de superfície nos filmes de Langmuir de POEA, em função da dopagem através de subfases ácidas.(a) $\mathrm{HClO}_{4}$; (b) $\mathrm{CF}_{3} \mathrm{COOH}$; (c) $\mathrm{H}_{2} \mathrm{SO}_{4}$; (d) $\mathrm{HCl}$.

FIGURA 13 - Variação do potencial de superficie para a PANi para um valor fixo de pH, em função do ácido utilizado na subfase.

FIGURA 14 - Variação do potencial de superfície para a POEA para um valor fixo de pH, em função do ácido utilizado na subfase.

FIGURA 15 - Variação do valor máximo atingido pelo potencial de superfície nos filmes Langmuir de POEA pré-dopada, em função da dopagem através de subfase ácida $\left(\mathrm{HClO}_{4}\right)$.

FIGURA 16- Espectro UV-vis de uma monocamada mista de PANi e estearato de cádmio: a) logo após a deposição; b) dopado em vapor de $\mathrm{HCl}$ por dez minutos.

FIGURA 17 - Espectro UV-vis de uma monocamada mista de 16-mero e estearato de cádmio: a) logo após a deposição; b) dopado em vapor de $\mathrm{HCl}$ por dez minutos.

FIGURA 18 - Variação da absorbância em função do número de camadas depositadas, em $590 \mathrm{~nm}$, para filmes mistos de PANi e estearato de cádmio.

FIGURA 19 - Variação da absorbância em função do número de camadas depositadas, em $590 \mathrm{~nm}$, para filmes mistos de16-mero e estearato de cádmio em diferentes percentagens de 16mero em massa na solução: ( ) 25\%; (O) 50\%; (A) $75 \%$.

FIGURA 20 - Variação da absorbância por camada depositada em função da percentagem utilizada de 16-mero na solução.

FIGURA 21 - Espectro de transmitância de FTIR de filme LB misto de PANi (55\% de polímero em massa na solução) e estearato de cádmio.

FIGURA 22 - Espectro de FTIR de filmes LB mistos (21 camadas) contendo diferentes percentagens de 16-mero e estearato de cádmio: a) 25\%; b) 50\% e c) 75\% de 16-mero na solução de espalhamento.

FIGURA 23 - Representação esquemática dos domínios de polianilina (ou 16-mero) com estearato de cádmio nos filmes $L B$.

FIGURA 24 - Espectros de difração de raios-X em filmes LB mistos de PANi com estearato de cádmio: a) CdSt puro; b) $30 \%$ de PANi; c) 43\% de PANi; d) 55\% de PANi; e) $66 \%$ de $P A N i$ 
FIGURA 25 - Espectros de difração de raios-X de filmes LB (21 camadas) contendo diferentes percentagens, em massa, de 16-mero e CdSt: (a) 25\%; (b) 50\%; (c) 64\% e (d) $75 \%$ de 16-mero.

FIGURA 26 - Representação esquemática dos domínios de polianilina com estearato de cádmio nos filmes LB quando elevadas percentagens de polímero são adicionadas em solução. _ 48

FIGURA 27 - Variação do índice de refração (n) e coeficiente de extinção (k), obtidos por elipsometria, em um filme LB de polianilina pura, contendo 9 camadas, utilizando subfase ácida $(p H \sim 2)$.

FIGURA 28 - Curvas (ПX A) de monocamadas de PANi processada com CSA na ausência (a) e na presença (b) de m-cresol na solução inicial, em subfases ácidas.

FIGURA 29 - Curvas (ПX A) de filmes LB mistos, contendo $50 \%$ em peso, de PANi/CdSt na ausência (a) e na presença (b) de m-cresol durante o processamento do polímero. 62

FIGURA 30 - Curvas de potencial de superficie para monocamadas de polianilina: (a) pura, formadas sobre subfases ácidas ( $\mathrm{pH}=2$, TSA) e (b) filmes mistos de PANi com estearato de cádmio.

FIGURA 31 - Espectros de UV-vis dos filmes $L B$ de PANi processada das seguintes formas: 65

FIGURA 32 - Espectros de UV-vis de filmes LB mistos contendo 50\% em massa de PANi e $\overline{C d S t}$. (a) PANi processada na ausência de m-cresol, e (b) PANi processada na presença de mcresol.

FIGURA 33 - Espectros de difração de raios-X em filmes LB mistos contendo 50\% em massa na solução de PANi/CSA com CdSt. (a) PANi processada na ausência de m-cresol, e (b) PANi processada na presença de m-cresol.

FIGURA 34 - Espectros de UV-vis para filmes LB mistos de polianilina com estearato de cádmio (21 camadas) durante os estágios iniciais de irradiação, em atmosfera ambiente $(\sim 50 \%$ de umidade).

FIGURA 35 -Espectros de UV-vis para filmes mistos de polianilina com estearato de cádmio (21 camadas), irradiados em atmosfera ambiente ( $50 \%$ de umidade), após um tempo prolongado de irradiação.

FIGURA 36 - Espectros de FTIR de filmes LB mistos de polianilina com CdSt: (a) recém depositados $e$ (b) expostos aos raios-X por 3 horas em atmosfera ambiente ( $50 \%$ de umidade) $\quad 76$

FIGURA 37 - Espectro de difração de raios-X de filmes LB mistos de polianilina com CdSt. (a) recém depositado, e (b) irradiado por 3 horas em atmosfera ambiente ( $50 \%$ de umidade). 77

FIGURA 38 - Espectros UV-vis para um filme LB contendo 84 camadas irradiado a atmosfera ambiente ( $50 \%$ de umidade) em diferentes intervalos de tempo, num total de 760 minutos de irradiação.

FIGURA 39 - Espectros UV-vis para um filme LB contendo 84 camadas irradiado em atmosfera ambiente a $90 \%$ de umidade, em diferentes intervalos de tempo, num total de 210 minutos de irradiação.

FIGURA 40 - Espectros UV-vis para filmes LB de PANi contendo 13 camadas, irradiados durante 45 minutos no vácuo e em atmosfera ambiente a $70 \%$ de umidade.

FIGURA 41 - Espectros UV-vis para filmes LB de PANi contendo 13 camadas em atmosfera de oxigênio. a) recém depositado; b) irradiado 45 minutos

FIGURA 42 - Espectros UV-vis para filmes $L B$ de PANi contendo 13 camadas em atmosfera de nitrogênio. a) recém depositado; b) irradiado 45 minutos em atmosfera de nitrogênio super-seco; c) irradiado 45 minutos em atmosfera de nitrogênio a 84\% de umidade. 81

FIGURA 43 - Espectros UV-vis para filmes LB de PANi contendo 13 camadas em atmosfera de argônio. a) recém depositado; b) irradiado 45 minutos em atmosfera de argônio; irradiado 45 minutos em atmosfera de argônio a 85\% de umidade.

FIGURA 44 - Variação no espectro de UV-vis em um filme LB de PANi contendo 13 camadas, em atmosfera de oxigênio.

FIGURA 45 - Espectros UV-vis para um filme LB contendo 11 camadas irradiado em atmosfera ambiente a 90\% de umidade, em diferentes intervalos de tempo, num total de 45 minutos de irradiação.

FIGURA 46 - Espectros UV-vis para um filme LB contendo 40 camadas irradiado em atmosfera
ambiente a $90 \%$ de umidade, em diferentes intervalos de tempo, num total de 130 minutos de irradiação. 
FIGURA 47 - Espectros UV-vis para um filme LB contendo 120 camadas irradiado em atmosfera ambiente a $90 \%$ de umidade, em diferentes intervalos de tempo, num total de 340 minutos de irradiação.

FIGURA 48 - Variação do tempo necessário para o aparecimento da banda de absorção polarônica nos espectro de UV-vis em função de espessura de filmes $L B$ de PANi/CdSt, irradiados a $90 \%$ de umidade, em diferentes intervalos de tempo.

FIGURA 49 - Efeito de dopagem ao vapor de $\mathrm{HCl}$, e efeitos de exposição aos raios-X num filme LB contendo 19 camadas depositadas

FIGURA 50 - Dopagem e desdopagem de um filme LB de PANi, contendo 84 camadas, após 760 minutos de irradiação em atmosfera ambiente a $50 \%$ de umidade.

FIGURA 51 - Dopagem e desdopagem de um filme LB de PANi, contendo 84 camadas, após 240 minutos de irradiação a $90 \%$ de umidade.

FIGURA 52 - Espectros UV-vis para um filme $L B$ de PANi, contendo 23 camadas, exposto ao vapor de $m$-cresol por 2 dias e irradiado durante 224 minutos em atmosfera ambiente a 50\% de umidade.

FIGURA 53 - Espectros UV-vis para um filme $L B$, contendo 23 camadas, irradiado durante 50 minutos a 90\% de umidade e, posteriormente, exposto ao vapor de m-cresol por 2 dias.

FIGURA 54 - Variações no espectro de UV-vis em filmes LB de PANi contendo 23 camadas, sem

irradiação, em diferentes condições de umidade.
FIGURA 55 - Variações no espectro de UV-vis de um filme LB de PANi contendo 84 camadas, mantido em repouso em atmosfera ambiente a $90 \%$ de umidade.

$$
\text { mantido em repouso em atmosfera ambiente a } 90 \% \text { de umidade. }
$$

FIGURA 56 - Variação no espectro de UV-vis em um filme LB de PANi contendo 40 camadas, mantida em repouso por dezoito horas em atmosfera a 90\% de umidade, após um hora de irradiação.

FIGURA 57 - Espectros UV-vis para um filme LB contendo 10 camadas: a) recém depositado; b)
irradiado 45 minutos em atmosfera de argônio; c) irradiado 30 minutos em atmosfera
ambiente a $90 \%$ de umidade com uma placa de quartzo de 1 mm de espessura sobre o
mesmo.
FIGURA 58 - Espectros UV-vis para filmes LB contendo 21 camadas, irradiados durante 40 minutos
em atmosfera ambiente ( $50 \%$ de umidade): a) recém depositado; b) irradiado ao ar
livre; c) irradiado dentro do tuperware.
FIGURA 59 - Espectros UV-vis para um filme LB contendo 10 camadas coberto com uma placa de
chumbo de 1,5 mm de espessura: a) recém depositado; b) irradiado 40 minutos em
atmosfera ambiente a $50 \%$ de umidade; c) irradiado 40 minutos em atmosfera ambiente
a $90 \%$ de umidade.

FIGURA 57 - Espectros UV-vis para um filme LB contendo 10 camadas: a) recém depositado; b)
irradiado 45 minutos em atmosfera de argônio; c) irradiado 30 minutos em atmosfera
ambiente a $90 \%$ de umidade com uma placa de quartzo de 1 mm de espessura sobre o
mesmo.
FIGURA 58 - Espectros UV-vis para filmes LB contendo 21 camadas, irradiados durante 40 minutos
em atmosfera ambiente ( $50 \%$ de umidade): a) recém depositado; b) irradiado ao ar
livre; c) irradiado dentro do tuperware.
FIGURA 59 - Espectros UV-vis para um filme LB contendo 10 camadas coberto com uma placa de
chumbo de 1,5 mm de espessura: a) recém depositado; b) irradiado 40 minutos em
atmosfera ambiente a $50 \%$ de umidade; c) irradiado 40 minutos em atmosfera ambiente
a $90 \%$ de umidade.

FIGURA 57 - Espectros UV-vis para um filme LB contendo 10 camadas: a) recém depositado; b)
irradiado 45 minutos em atmosfera de argônio; c) irradiado 30 minutos em atmosfera
ambiente a $90 \%$ de umidade com uma placa de quartzo de 1 mm de espessura sobre o
mesmo.
FIGURA 58 - Espectros UV-vis para filmes LB contendo 21 camadas, irradiados durante 40 minutos
em atmosfera ambiente ( $50 \%$ de umidade): a) recém depositado; b) irradiado ao ar
livre; c) irradiado dentro do tuperware.
FIGURA 59 - Espectros UV-vis para um filme LB contendo 10 camadas coberto com uma placa de
chumbo de 1,5 mm de espessura: a) recém depositado; b) irradiado 40 minutos em
atmosfera ambiente a $50 \%$ de umidade; c) irradiado 40 minutos em atmosfera ambiente
a $90 \%$ de umidade.

FIGURA 57 - Espectros UV-vis para um filme LB contendo 10 camadas: a) recém depositado; b)
irradiado 45 minutos em atmosfera de argônio; c) irradiado 30 minutos em atmosfera
ambiente a $90 \%$ de umidade com uma placa de quartzo de 1 mm de espessura sobre o
mesmo.
FIGURA 58 - Espectros UV-vis para filmes LB contendo 21 camadas, irradiados durante 40 minutos
em atmosfera ambiente ( $50 \%$ de umidade): a) recém depositado; b) irradiado ao ar
livre; c) irradiado dentro do tuperware.
FIGURA 59 - Espectros UV-vis para um filme LB contendo 10 camadas coberto com uma placa de
chumbo de 1,5 mm de espessura: a) recém depositado; b) irradiado 40 minutos em
atmosfera ambiente a $50 \%$ de umidade; c) irradiado 40 minutos em atmosfera ambiente
a $90 \%$ de umidade.

FIGURA 57 - Espectros UV-vis para um filme LB contendo 10 camadas: a) recém depositado; b)
irradiado 45 minutos em atmosfera de argônio; c) irradiado 30 minutos em atmosfera
ambiente a $90 \%$ de umidade com uma placa de quartzo de 1 mm de espessura sobre o
mesmo.
FIGURA 58 - Espectros UV-vis para filmes $L B$ contendo 21 camadas, irradiados durante 40 minutos
em atmosfera ambiente ( $50 \%$ de umidade): a) recém depositado; b) irradiado ao ar
livre; c) irradiado dentro do tuperware.
FIGURA 59 - Espectros UV-vis para um filme LB contendo 10 camadas coberto com uma placa de
chumbo de 1,5 mm de espessura: a) recém depositado; b) irradiado 40 minutos em
atmosfera ambiente a $50 \%$ de umidade; c) irradiado 40 minutos em atmosfera ambiente
a $90 \%$ de umidade.

FIGURA 57 - Espectros UV-vis para um filme LB contendo 10 camadas: a) recém depositado; b)
irradiado 45 minutos em atmosfera de argônio; c) irradiado 30 minutos em atmosfera
ambiente a $90 \%$ de umidade com uma placa de quartzo de 1 mm de espessura sobre o
mesmo.
FIGURA 58 - Espectros UV-vis para filmes LB contendo 21 camadas, irradiados durante 40 minutos
em atmosfera ambiente ( $50 \%$ de umidade): a) recém depositado; b) irradiado ao ar
livre; c) irradiado dentro do tuperware.
FIGURA 59 - Espectros UV-vis para um filme LB contendo 10 camadas coberto com uma placa de
chumbo de 1,5 mm de espessura: a) recém depositado; b) irradiado 40 minutos em
atmosfera ambiente a $50 \%$ de umidade; c) irradiado 40 minutos em atmosfera ambiente
a $90 \%$ de umidade.

FIGURA 57 - Espectros UV-vis para um filme LB contendo 10 camadas: a) recém depositado; b)
irradiado 45 minutos em atmosfera de argônio; c) irradiado 30 minutos em atmosfera
ambiente a $90 \%$ de umidade com uma placa de quartzo de 1 mm de espessura sobre o
mesmo.
FIGURA 58 - Espectros UV-vis para filmes LB contendo 21 camadas, irradiados durante 40 minutos
em atmosfera ambiente ( $50 \%$ de umidade): a) recém depositado; b) irradiado ao ar
livre; c) irradiado dentro do tuperware.
FIGURA 59 - Espectros UV-vis para um filme LB contendo 10 camadas coberto com uma placa de
chumbo de 1,5 mm de espessura: a) recém depositado; b) irradiado 40 minutos em
atmosfera ambiente a $50 \%$ de umidade; c) irradiado 40 minutos em atmosfera ambiente
a $90 \%$ de umidade.

FIGURA 57 - Espectros UV-vis para um filme LB contendo 10 camadas: a) recém depositado; b)
irradiado 45 minutos em atmosfera de argônio; c) irradiado 30 minutos em atmosfera
ambiente a $90 \%$ de umidade com uma placa de quartzo de 1 mm de espessura sobre o
mesmo.
FIGURA 58 - Espectros UV-vis para filmes LB contendo 21 camadas, irradiados durante 40 minutos
em atmosfera ambiente ( $50 \%$ de umidade): a) recém depositado; b) irradiado ao ar
livre; c) irradiado dentro do tuperware.
FIGURA 59 - Espectros UV-vis para um filme LB contendo 10 camadas coberto com uma placa de
chumbo de 1,5 mm de espessura: a) recém depositado; b) irradiado 40 minutos em
atmosfera ambiente a $50 \%$ de umidade; c) irradiado 40 minutos em atmosfera ambiente
a $90 \%$ de umidade.

FIGURA 57 - Espectros UV-vis para um filme LB contendo 10 camadas: a) recém depositado; b)
irradiado 45 minutos em atmosfera de argônio; c) irradiado 30 minutos em atmosfera
ambiente a $90 \%$ de umidade com uma placa de quartzo de 1 mm de espessura sobre o
mesmo.
FIGURA 58 - Espectros UV-vis para filmes LB contendo 21 camadas, irradiados durante 40 minutos
em atmosfera ambiente ( $50 \%$ de umidade): a) recém depositado; b) irradiado ao ar
livre; c) irradiado dentro do tuperware.
FIGURA 59 - Espectros UV-vis para um filme LB contendo 10 camadas coberto com uma placa de
chumbo de 1,5 mm de espessura: a) recém depositado; b) irradiado 40 minutos em
atmosfera ambiente a $50 \%$ de umidade; c) irradiado 40 minutos em atmosfera ambiente
a $90 \%$ de umidade.

FIGURA 57 - Espectros UV-vis para um filme LB contendo 10 camadas: a) recém depositado; b)
irradiado 45 minutos em atmosfera de argônio; c) irradiado 30 minutos em atmosfera
ambiente a $90 \%$ de umidade com uma placa de quartzo de $1 \mathrm{~mm}$ de espessura sobre o
mesmo.
93
FIGURA 58 - Espectros UV-vis para filmes LB contendo 21 camadas, irradiados durante 40 minutos
em atmosfera ambiente ( $50 \%$ de umidade): a) recém depositado; b) irradiado ao ar
livre; c) irradiado dentro do tuperware.
FIGURA 59 - Espectros UV-vis para um filme LB contendo 10 camadas coberto com uma placa de
chumbo de 1,5 mm de espessura: a) recém depositado; b) irradiado 40 minutos em
atmosfera ambiente a $50 \%$ de umidade; c) irradiado 40 minutos em atmosfera ambiente
a $90 \%$ de umidade.

FIGURA 57 - Espectros UV-vis para um filme LB contendo 10 camadas: a) recém depositado; b)
irradiado 45 minutos em atmosfera de argônio; c) irradiado 30 minutos em atmosfera
ambiente a $90 \%$ de umidade com uma placa de quartzo de 1 mm de espessura sobre o
mesmo.
FIGURA 58 - Espectros UV-vis para filmes LB contendo 21 camadas, irradiados durante 40 minutos
em atmosfera ambiente ( $50 \%$ de umidade): a) recém depositado; b) irradiado ao ar
livre; c) irradiado dentro do tuperware.
FIGURA 59 - Espectros UV-vis para um filme LB contendo 10 camadas coberto com uma placa de
chumbo de 1,5 mm de espessura: a) recém depositado; b) irradiado 40 minutos em
atmosfera ambiente a $50 \%$ de umidade; c) irradiado 40 minutos em atmosfera ambiente
a $90 \%$ de umidade.

FIGURA 60 - Representação esquemática do método de medida de condutividade elétrica utilizando dois pontos de contato. 104

FIGURA 61 - Representação esquemática do método de medida de condutividade elétrica através de quatro pontas colineares. 105

FIGURA 62 - Representação esquemática do método de medidas de quatro pontas eqüidistantes, mas não colineares. 106

FIGURA 63 - Representação esquemática das medidas de condutividade elétrica utilizando o método de van de Pauw.

FIGURA 64 - Representação esquemática do comportamento para a condutividade a.c. em materiais desordenados.

FIGURA 65 - Representação esquemática da disposição dos contatos elétricos nas medidas de condutividade a.c.. A e B representam os pontos nos quais foram presos os fios para realização das medidas.

FIGURA 66 - Comportamento da componente real da condutividade complexa em função da freqüencia, em filmes LB mistos de PANi com CdSt.

FIGURA 67 - Variação da condutividade a $1 \mathrm{~Hz}$ em filmes LB mistos de PANi/CdSt, variando o tempo de exposição da amostra aos raios- $X$. 


\section{LISTA DE TABELAS}

TABELA 1 - Variação do potencial de superficie da PANi em função do pH da subfase. 33

TABELA 2 - Variação do potencial de superficie da POEA não pré-dopada em função do pH da subfase.

TABELA 3 - Variação do potencial de superficie da POEA pré-dopada em função do pH da subfase. 34

TABELA 4 - Valores de potencial de superficie para filmes LB mistos contendo diferentes quantidades de PANi e estearato de cádmio.

TABELA 5 - Valores de potencial de superficie para filmes LB mistos contendo diferentes quantidades de 16-mero e estearato de cádmio.

TABELA 6 - Resultados elipsométricos (constantes ópticas e espessura por camada) de filmes LB contendo diferentes percentagens de PANi e CdSt.

TABELA 7 - Resultados elipsométricos (constantes ópticas e espessura por camada) de filmes LB contendo diferentes percentagens de 16-mero e CdSt.

TABELA 8 - Valores máximos atingidos pelo potencial de superficie em filmes LB mistos, contendo $50 \%$ em massa, de PANi e estearato de cádmio, na ausência e na presença de m-cresol em diferentes condições de subfase.

TABELA 9 - Resultados de condutividade elétrica (van der Pauw) em filmes LB de polianilina processada apenas com CSA, obtidos em subfases ácidas.

TABELA 10 - Resultados de condutividade elétrica (van der Pauw) em filmes LB de polianilina processada com CSA e m-cresol, obtidos em subfases ácidas.

TABELA 11 - Resultados de condutividade elétrica (van der Pauw) em filmes LB mistos de polianilina com estearato de cádmio.

TABELA 12 -Resultados de condutividade elétrica (van der Pauw) em filmes LB de 16-mero processado com CSA e m-cresol, obtidos em subfases ácidas.

TABELA 13 - Resultados de condutividade elétrica (van der Pauw) em filmes LB mistos de 16-mero com estearato de cádmio.

TABELA 14- Resultados de condutividade elétrica (duas pontas) em filmes LB mistos de 16-mero com estearato de cádmio (50\%). 


\section{LISTA DE ABREVIATURAS E SIGLAS}

Ast - Ácido esteárico

AFM - Microscopia de força atômica, do inglês Atomic Force Microscopy

BAM - Microscopia no ângulo de Brewster

CA - Derivado fosforilatado de calix[4]resorcilolareno

$\mathrm{CdSt}$ - Estearato de cádmio

CSA - Ácido canforssulfônico

DBSA - Ácido dodecilbenzenossulfônico

DF - Demchack e Fort

FTIR - Espectroscopia na região do infravermelho

GC - Gouy Chapman

HPLC - High Perfomance Liquid Cromatography

LB - Langmuir-Blodgett

$\mathrm{nm}$ - Nanometros

NMP - N-metilpirrolidinona

PANi - Polianilina

$\mathrm{PANi}_{2}$ - Polianilina obtida por uma rota de síntese alternativa

POMA - Poli (o-anisidina)

POEA - Poli(o-etoxianilina)

TFA - Ácido trifluoracético

TR - Razão de transferência dos filmes Langmuir-Blodgett, do inglês Transfer ratio TSA - Ácido toluenossulfônico

UV-vis - Espectroscopia na região do ultravioleta e do visível

XRD - Difração de raios-X, do inglês $X$-ray diffraction

$\mathrm{ZnSe}$ - Seleneto de zinco 


\section{LISTA DE SÍMBOLOS}

16-mero - oligômero de polianilina

$\mathrm{A}$ - área molecular média

a.c. - medidas elétricas em corrente alternada

$\mathrm{A}_{\mathrm{c}}$ - área crítica

$A_{e}$ - área de contato do eletrodo de medida

$\alpha$ - constante de dissociação

$\alpha^{\prime}-$ absorção óptica do material

c - concentração iônica da subfase

$\mathrm{CaF}_{2}-$ Fluoreto de cálcio

$\mathrm{CHCl}_{3}-$ Clorofórmio

$\mathrm{d}$ - espessura por camada

d.c. - medidas elétricas em corrente contínua

$\mathrm{d}_{\sigma}$ - densidade superficial de cargas na interface filme/subfase

$\Delta \mathrm{V} X \mathrm{~A}$ - curva de potencial de superfície em função da área molecular média $\Delta \mathrm{V}$ - potencial de superfície

$\Delta \mathrm{V}_{\mathrm{LB}}-$ potencial de superfície nos filmes Langmuir-Blodgett

$\Delta \mathrm{t}$ - intervalo de tempo

$e$ - carga eletrônica

$\varepsilon_{0}$ - permissividade elétrica do vácuo

$\varepsilon_{\mathrm{i}}-$ constante dielétrica do meio $\mathrm{i}$

$\mathrm{HCl}$ - Ácido clorídrico

$\mathrm{i}$ - corrente elétrica

$\mathrm{k}$ - coeficiente de extinção

$\mathrm{KCl}$ - Cloreto de potássio

$k$ - constante de Boltzmann

$\lambda$ - comprimento de onda

$\mu_{\mathrm{i}}$ - contribuição dipolar da parte $i$ da molécula normal a interface filme/água

$\mu_{1}-$ coeficiente de absorção linear

$\mathrm{n}$ - índice de refração 
$\Pi$ - pressão de superfície

П X A - curva de pressão de superfície em função da área molecular média

$\Psi_{0}$ - potencial de superfície da dupla camada formada na interface filme/subfase

$\mathrm{S}$ - distância de separação entre as pontas de contato para medidas de condutividade elétrica

$\sigma$ - condutividade elétrica

$\sigma^{\prime}(\omega)$ - componente real da condutividade complexa

$\sigma ”(\omega)$ - componente imaginária da condutividade complexa

$\mathrm{T}$ - temperatura absoluta

$\mathrm{V}$ - diferença de potencial

$\mathrm{V}_{0}$ - valor estipulado para o potencial de superfície

$\mathrm{V}_{\mathrm{m}}$ - máximo valor do potencial de superfície

$\omega$ - freqüência

Z' $(\omega)$ - componente real da impedância

Z" $(\omega)$ - componente imaginária da impedância 